\title{
ESCOLA DE COMUNICAÇÕES E ARTES
}

UNIVERSIDADE DE SÃO PAULO

JOÃO BAPTISTA GODOY DE SOUZA

Procedimentos de trabalho na captação de som direto nos longas-metragens brasileiros Contra todos e Antônia: a técnica e o espaço criativo 


\section{JOÃO BAPTISTA GODOY DE SOUZA}

\section{Procedimentos de trabalho na captação de som direto nos longas-metragens brasileiros Contra todos e Antônia: a técnica e o espaço criativo}

Tese apresentada à Escola de Comunicações e Artes da Universidade de São Paulo para obtenção do título de Doutor em Ciências da Comunicação.

Área de Concentração: Estudo dos Meios e da Produção Mediática

Orientadora: Profa. Dra. Maria Dora Genis Mourão 
Autorizo a reprodução e divulgação total ou parcial deste trabalho, por qualquer meio convencional ou eletrônico, para fins de estudo e pesquisa, desde que citada a fonte.

Souza, João Baptista Godoy.

Procedimentos de trabalho na captação de som direto nos longasmetragens brasileiros Contra todos e Antônia: a técnica e o espaço criativo / João Baptista Godoy Souza; orientador Maria Dora Genis Mourão. - São Paulo, 2010.

196f.: Il.

Tese (Doutorado) - Universidade de São Paulo, 2010.

1. Cinema 2. Som (cinema) 3. Som - captação. I. Mourão, Maria Dora Genis. II. Título. III. Título: a técnica e o espaço criativo. 
Nome: SOUZA, J. B. G.

Título: Procedimentos de trabalho na captação de som direto nos longas-metragens brasileiros Contra todos e Antônia: a técnica e o espaço criativo.

Tese apresentada à Escola de Comunicações e Artes da Universidade de São Paulo para a obtenção do título de Doutor em Ciências da Comunicação.

Aprovado em: I

Banca Examinadora

Prof. Dr. : Instituição:

Julgamento:

Assinatura:

Prof. Dr. Instituição:

Julgamento:

Assinatura:

Prof. Dr. : Instituição:

Julgamento: Assinatura:

Prof. Dr. : Instituição:

Julgamento: Assinatura:

Prof. Dr. : Instituição:

Julgamento: Assinatura: 
À minha esposa Valéria e aos meus filhos Pedro e Nina, com imenso amor.

Ao meu pai Hélio Moacyr de Souza (in memoriam) e à minha mãe Edith Godoy, com gratidão. 


\section{AGRADECIMENTOS}

À Profa. Dra. Maria Dora Genis Mourão, pela orientação e apoio generoso durante o percurso.

Ao Prof. Dr. Eduardo Santos Mendes, pelas indicações e questionamentos sempre estimulantes.

Aos colegas do CTR que generosamente me apoiaram. Em particular, Vânia Debs e Esther Hambúrguer, que nos momentos cruciais apontaram a direção correta.

À minha família pelo amor, em especial à Valéria, minha companheira, pelo apoio constante, ajudando a superar as dificuldades que surgiram pelo caminho. Ao Pedro, meu filho, pela inestimável ajuda e pela atenção que dedicou à irmã nas ausências do pai. À Nina, que compreendeu a importância do trabalho e torceu pelo seu final.

Ao meu mestre de ofício, Geraldo Ribeiro.

Ao amigo José Rafael, pelo incansável incentivo em todos os momentos e pelo diálogo motivador.

Ao grande amigo André Gurgel, pela disponibilidade e presença valiosa.

À Dona Cida Ferranti, pelo equilíbrio do campo energético.

À minha mãe e ao meu irmão, Hélio Godoy, pelo encorajamento.

E a Deus, por iluminar o caminho. 
You can't be a soundman and do location work and not be assertive and not fight for good sound tracks.

Chris Newman 


\section{RESUMO}

SOUZA, J. B. G. de. Procedimentos de trabalho na captação de som direto nos longasmetragens brasileiros Contra todos e Antônia: a técnica e o espaço criativo. 2010. 196f. Tese (Doutorado em Ciências da Comunicação) - Escola de Comunicações e Artes, Universidade de São Paulo, São Paulo, 2010.

Este estudo é uma reflexão sobre a prática de trabalho do registro sonoro sincrônico centrado na descrição e na análise dos procedimentos empregados na captação de som direto na realização dos longas-metragens brasileiros Contra todos e Antônia. A prática do registro sonoro sincrônico é conceituada como um método de trabalho compartilhado por uma categoria profissional, com procedimentos norteados por parâmetros técnicos que se conformaram precocemente no período de transição para o cinema sonoro durante a constituição do código de representação do cinema clássico norte-americano. Dependente da tecnologia, o método de trabalho de captação de som direto reestrutura-se com o advento de novas ferramentas, permitindo o surgimento de formas alternativas de realização. As experiências analisadas permitem perceber o amplo espectro de escolhas envolvidas na atuação do profissional do som direto, indicando a existência de uma componente criativa na aplicação e desenvolvimento desta prática de trabalho. Premissas particulares de realização, condicionantes orçamentárias e o advento de nova tecnologia estimulam o surgimento de procedimentos que dinamicamente reanimam o tradicional método de trabalho de captação de som direto.

Palavras-chave: Cinema. Som direto. Técnico de som direto. 


\begin{abstract}
SOUZA, J. B. G. of. Working methods in synchronous sound recording in the Brazilian feature films Contra todos and Antônia: techniques and creative space. 2010. 196f. Thesis (Ph.D. in Communication Sciences) - School of Arts and Communication, University of São Paulo, São Paulo, 2010.
\end{abstract}

This study is a reflection on the working methods of synchronous sound recording focusing on the description and analysis of the procedures used in the sound recording of the Brazilian feature films Contra todos and Antônia. The practice of synchronous sound recording is conceived as a working method shared by professional recordists, with procedures guided by technical parameters that surfaced very early in the transition period from silent to sound films, then to the establishment of representational standards of the American classical cinema. Being technology dependent, the working method of sound recording renews itself with the coming of new tools, that enables new ways of working. The experiences in focus reveal the broad spectrum of choices involved in the practice of the sound recordist, unveiling the existence of a creative component in the process. Production issues, budgetary constraints and the advent of new technology stimulate the emergence of procedures that dynamically reform the traditional working method in sound recording.

Keywords: Cinema. Direct sound. Direct sound recordist. 


\section{LISTA DE FIGURAS}

Figura 1 - Representação gráfica e fotograma com som óptico de densidade variável. Trilha sonora impressa entre a lateral dos fotogramas e as perfurações.

Figura 2 - Representação gráfica e fotograma com som óptico de área variável. Na representação gráfica, óptico duplex de área variável. No fotograma, óptico unilateral de área variável

Figura 3 - Boletim de som direto diagramado para captação com plataforma multipista 102 


\section{LISTA DE FOTOGRAMAS}

Fotogramas 1 - Sequência Despedida na plataforma, do filme A testemunha

Fotogramas 2 - Sequência 01, Assistindo vídeo na casa de Teodoro

Fotogramas 3 - Sequência 18, Teodoro espanca Soninha

Fotogramas 4 - Sequência 22, Oração na casa do enfermo

Fotogramas 5 - Sequência 27, Soninha caminha com a amiga e encontra Marcão 139

Fotogramas 6 - Sequência 43, Waldomiro e Cláudia no quarto do hotel 142

Fotogramas 7 - Sequência 52, Teodoro assassina Marcão 144

Fotogramas 8 - Sequência 03, Na van pedido para abrir o show do grupo O Poder 160

Fotogramas 9 - Sequência 12, Ensaio do Antônia no ginásio 163

Fotogramas 10 - Sequência 14, Caminhada para a festa de rua 165

Fotogramas 11- Sequência 15, Festa de rua 167

Fotogramas 12 - Sequência 19, Preta chega à casa da mãe / Canto evangélico..... 172

Fotogramas 13 - Sequência 21, Festa de burguês / Killing me softly. 175

Fotogramas 14 - Sequências 33 e 35, Caminhada Brasilândia - Provocação

Robinho e Espancamento Robinho 176 


\section{LISTA DE FOTOS}

Foto 1 - Gravador de som do sistema Vitaphone (recording lathe) ................................ 35

Foto 2 - Projetor de imagens integrado mecanicamente ao toca-discos ......................... 36

Foto 3 - A soundproof booth construída sobre rodas com revestimento interno para absorção do som 48

Foto 4 - Boom da Mole-Richardson - modelo 103B sustentado por tripé com rodas 58

Foto 5 - Rolo de "magnético perfurado" com bitola $35 \mathrm{~mm}$ 62

Foto 6 - Nagra III com carretéis de 05 polegadas de diâmetro 68

Foto 7 - Nagra III com carretéis de 07 polegadas de diâmetro. 69

Foto 8 - Gravador DAT da HHB, modelo PORTADAT PDR 1000 TC com módulo de time code

Foto 9 - Equipe de captação configurada em double system portátil com gravador analógico Nagra e câmera Aaton super 16 mm.

Foto 10 - Equipe de captação do documentário Fé, configurada em double system portátil: gravador DAT, mixer e câmera Aaton super $16 \mathrm{~mm}$

Foto 11 - Configuração double system com portabilidade reduzida. Tomada de cena do longa-metragem $O$ menino da porteira, em 2008, na cidade de Brotas/SP.

Foto 12 - Configuração double system com alta portabilidade. Tomada de cena do longa-metragem Não por acaso, em 2006, na cidade de São Paulo/SP 84

Foto 13 - Configuração double system com alta portabilidade. 84

Foto 14 - Cena do filme Momento de decisão 108

Foto 15 - Cena do filme Momento de decisão...... 109 
Foto 16- Microfone modular da Schoeps com o swivel entre a cápsula e o amplificador

Foto 17 - Vista frontal superior do gravador Cantar-X.

Foto 18 - Tenda árabe cobrindo o teto da locação casa de JP, tomada de cena sequência 51 - Lena e Maionezi brigam. Frame extraído do making of do filme Antônia

Foto 19 - Tomada de cena da sequência 14 - Caminhada para a festa de rua (primeira filmagem). Frame extraído do making of do filme Antônia

Foto 20 - Tomada de cena da sequência 8 - Espera do trem na estação.

Foto 21 - Microfone sustentado pelo boom. Captação da sequência 15 - Festa de rua. Frame extraído do making of do filme Antônia

Foto 22 - Captação do som com dois booms cobrindo áreas diferentes. Captação da sequência 15 - Festa de rua. Frame extraído do making of do filme Antônia.

Foto 23 - Captação da sequência 15 - Festa de rua. Arranjo de alta portabilidade, gravador e receptores dos sistemas de radiotransmissão presos ao corpo 


\section{LISTA DE GRÁFICOS}

Gráfico 1 - Distância do microfone em função da distância focal da lente .55 


\section{LISTA DE SIGLAS}

AMPAS

Academy of Motion Pictures Arts and Sciences

ASC

American Society of Cinematographers

DAT

Digital Audio Tape

ERPI

Electrical Research Products Incorporation

GE

General Electric and Westinghouse

MGM

Metro-Goldwyn-Mayer

MOS

Motor Only Sinch

PA

Public Address System

RCA

Radio Corporation of America

RKO

Radio-Keith-Orpheum

SMPE

Society of Motion Picture Engineers

SMPTE

Society of Motion Picture and Television Engineers 


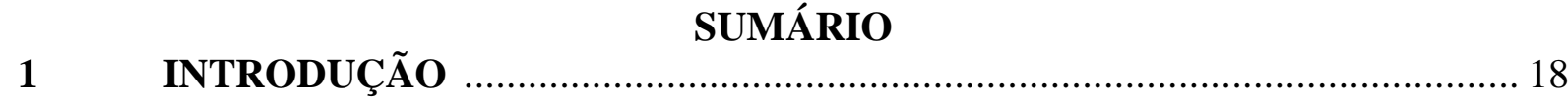

2 O FILME SONORO E O NASCIMENTO DO SOM DIRETO ..................... 23

2.1 A aposta empresarial no som sincrônico …..................................................... 24

2.2 Sistemas de gravação e reprodução sincrônicos .................................................... 34

2.2.1 Sistema de som no disco (sound-on-disc system) - Vitaphone .............................. 34

2.2.2 Sistema de som no filme (sound-on-film system) …........................................ 38

2.3 As mudanças de procedimentos de realização e a inserção do som no estilo

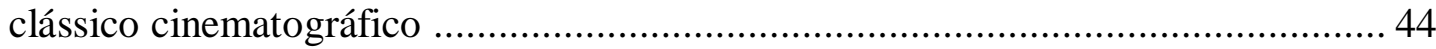

2.4 A técnica e os Procedimentos de captação de som nos primeiros tempos ............... 51

2.5 Nova tecnologia e novos procedimentos na captação do som direto ....................... 61

3 A PRÁTICA DE CAPTAÇÃO DO SOM DIRETO …............................... 76

3.1 Configuração técnica e constituição da equipe ….......................................... 77

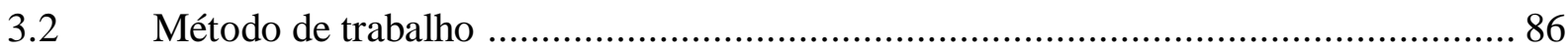

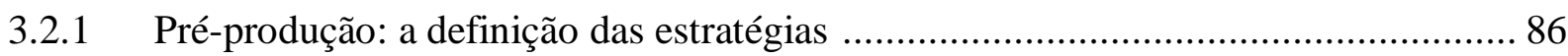

3.2.2 Filmagem: a captação e o registro do som direto ............................................. 89

3.2.2.1 A rotina de trabalho do som direto no set ............................................................ 96

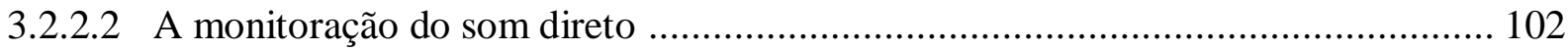

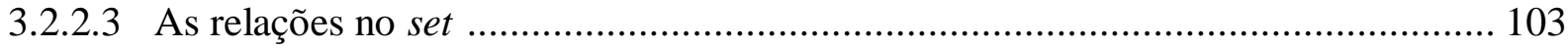

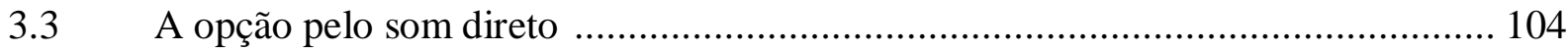

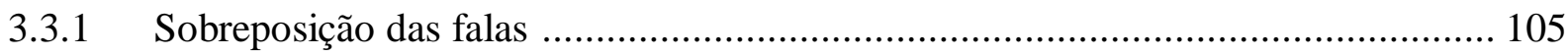

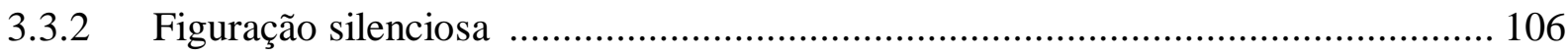

3.3.3 Ações potencialmente ruidosas .............................................................. 107

3.3.4 Opção de decupagem e a viabilidade do som direto ........................................ 109

4 A CAPTAÇÃO DO SOM DIRETO NOS LONGAS-METRAGENS:

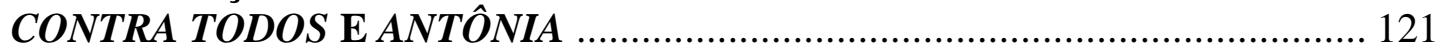

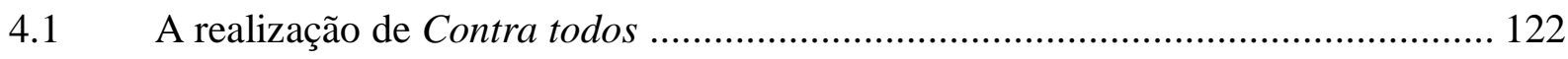

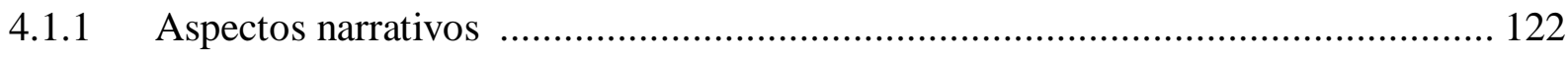




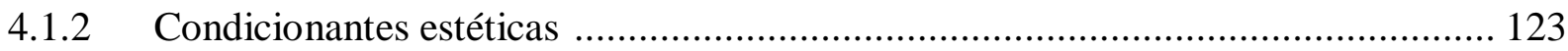

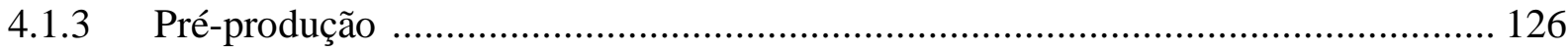

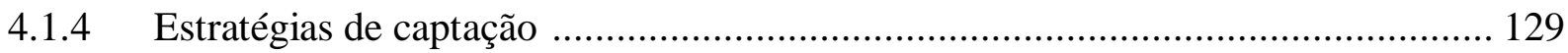

4.1.4.1 Sequência 01 - Assistindo vídeo na casa de Teodoro ........................................... 131

4.1.4.2 Sequência 18 - Teodoro espanca Soninha ..................................................... 135

4.1.4.3 Sequência 22 - Oração na casa do enfermo ..................................................... 138

4.1.4.4 Sequência 27 - Soninha caminha com a amiga e encontra Marcão ...................... 139

4.1.4.5 Sequência 43 - Waldomiro e Cláudia no quarto do hotel ................................... 141

4.1.4.6 Sequência 52 - Teodoro assassina Marcão ........................................................ 143

4.2 A realização de Antônia ........................................................................... 146

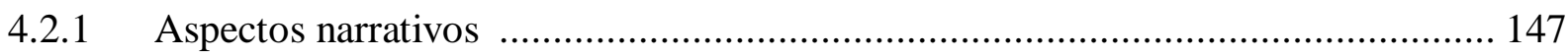

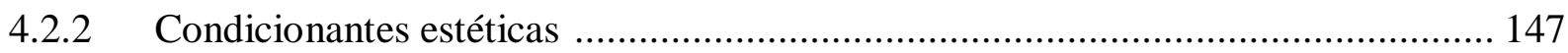

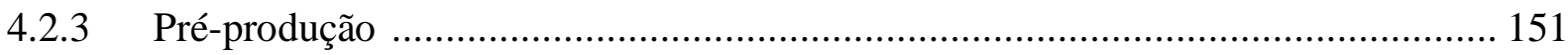

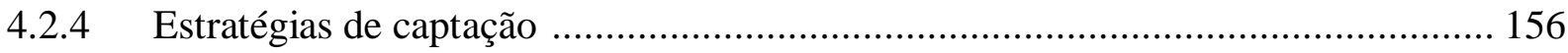

4.2.4.1 Sequência 03 - Na van pedido para abrir o show do grupo O Poder ..................... 159

4.2.4.2 Sequência 12 - Ensaio do Antônia no ginásio .................................................... 162

4.2.4.3 Sequência 14 - Caminhada para a festa de rua ................................................... 165

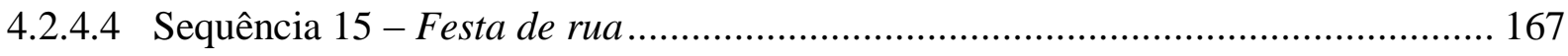

4.2.4.5 Sequência 19 - Preta chega à casa da mãe / Canto evangélico ........................... 172

4.2.4.6 Sequência 21 - Festa de burguês / Killing me softly ........................................ 174

4.2.4.7 Sequência 33 - Caminhada Brasilândia - Provocação Robinho / Sequência 35 Caminhada Brasilândia - Espancamento Robinho .......................................... 176

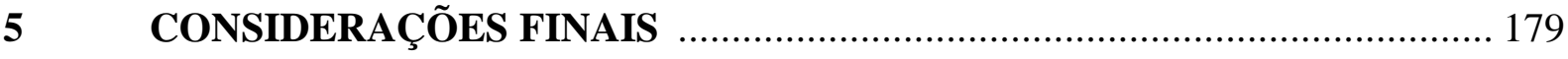

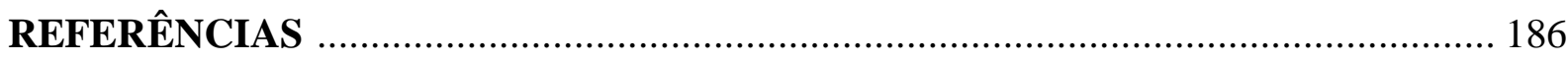

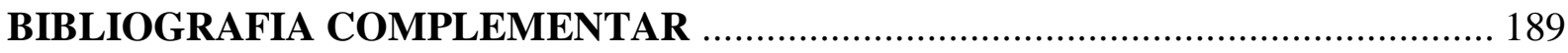

APENDICE A - LISTA DAS SEQUÊNCIAS DE CONTRA TODOS ......................... 192

APENDICE B - LISTA DAS SEQUÊNCIAS DE ANTÔNIA .................................. 195 


\section{INTRODUÇÃO}

Este trabalho busca sistematizar e analisar os procedimentos empregados na captação e no registro do som cinematográfico sincrônico. Essa prática, denominada no Brasil de "som direto", se conformou a partir do advento do cinema sonoro, no final da década de 1920, no seio da indústria cinematográfica norte-americana. A incorporação do som sincrônico pelo sistema de produção do cinema clássico definiu o padrão de qualidade do som direto, que se perpetuou ao longo dos anos e está presente nas práticas atuais de captação. Entendemos que a "natural" qualidade do som direto, coerente com a estética de representação do cinema narrativo, é obtida por meio de procedimentos pertencentes a um método de trabalho comum, compartilhado pelos profissionais da área de captação de som em diferentes cinematografias. O interesse central deste trabalho é localizar os procedimentos básicos da prática do som direto, a correlação com o aparato tecnológico e seus desdobramentos estéticos e operacionais.

A captação do som direto carrega o conflito original da vinculação com a captação simultânea da imagem. A dependência do som direto em relação à imagem condiciona os procedimentos de captação, os quais estão continuamente subordinados às necessidades da composição visual e do enquadramento da cena. A consequência direta desta relação é que inexiste autonomia para a captação do som durante a filmagem; o som direto não existe por si só. Michel Chion (1992, p. 233, tradução nossa) explicita a contradição primordial enfrentada pelo registro sonoro sincrônico, ao afirmar que é esperado, ao mesmo tempo, "a perfeita inteligibilidade do principal elemento do conjunto sonoro, a fala do ator, além de uma boa representação do espaço que a contêm" desde que seja respeitada a convenção de manter o microfone fora do quadro definido pela câmera. É a busca pela resolução desta equação que estrutura o método de trabalho empregado pelo técnico de som direto.

Embasado pela minha experiência profissional na captação de som sincrônico, desenvolvida desde 1988 no mercado de realização audiovisual brasileiro, este trabalho busca refletir sobre a possibilidade de atuação criativa do técnico de som direto no âmbito desta atividade rigidamente condicionada por parâmetros técnicos. Os procedimentos de captação de som direto empregados na realização dos longas-metragens Contra todos e Antônia, descritos no capítulo 4, evidenciam a complexidade e o dinamismo do método de trabalho e disponibilizam elementos para a reflexão do papel desempenhado pelo profissional do som direto. 
Como procedimento fundamental da prática de trabalho do som direto, no ato da captação, o técnico de som julga se as características técnicas/estéticas do material registrado permitem a sua utilização na trilha sonora finalizada. A qualidade do som direto é avaliada pela percepção auditiva do técnico de som, considerando basicamente três aspectos do registro sonoro: a fidelidade ao evento acústico original, a homogeneidade e a inteligibilidade da voz.

A fidelidade ao evento acústico original é a condição elementar do som direto: um registro de áudio ${ }^{1}$ que representa um evento sonoro. Neste aspecto, o ponto central é a precisão na qual é feita a "tradução" do evento acústico, ou seja, quão fiel é o registro em relação ao evento físico representado. A fidelidade do áudio resulta das características técnicas dos equipamentos (microfones, mesa de mixagem, gravador) empregados no sistema de captação e gravação. A qualidade dos equipamentos é descrita por meio de especificações técnicas mensuráveis, tais como: a "relação sinal ruído" (signal-to-noise-ratio), a quantidade de ruído eletroeletrônico latente ao sistema; a "resposta de frequência" (frequency response), capacidade em reproduzir as frequências entregues ao sistema sem alterar seu equilíbrio; o "intervalo dinâmico" (dynamic range), como o intervalo entre o som mais suave percebido e mais intenso suportado; a "distorção harmônica total" (total harmonic distortion), a quantidade de frequências harmônicas aleatórias adicionadas ao sinal original na saída do sistema; e ainda, a "estabilidade da velocidade" (wow and flutter), como a manutenção da velocidade $^{2}$ durante a gravação e a reprodução do registro sonoro. $\mathrm{O}$ aprofundamento destes aspectos, que permeiam o método de trabalho do técnico de som direto, vai além do interesse da nossa pesquisa. Assumimos que o profissional do som direto está habilitado a avaliar, a partir das especificações técnicas, a adequação dos equipamentos empregados e, principalmente, na prática do trabalho, é capaz de julgar auditivamente se estas especificações se traduzem em um registro de áudio cristalino e fiel ao timbre original da fonte sonora captada. Esta capacidade sensorial é denominada por Michel Chion (1992, p. 241) como a "cultura auditiva" que resulta da experiência acumulada, constituindo a principal ferramenta de trabalho dos profissionais que lidam com a matéria sonora.

\footnotetext{
${ }^{1}$ Áudio é entendido como a representação elétrica do fenômeno acústico que trafega nos circuitos dos equipamentos eletrônicos, ou como uma grandeza magnética, proporcional ao som que representa, gravada em uma fita.

2 A alteração na velocidade de gravação ou reprodução de uma fita com áudio registrado analogicamente resulta em correspondentes alterações na frequência do som e são percebidas como alteração de tonalidade. No caso do registro do som direto, a alteração de velocidade, além da mudança de tonalidade, acarreta a perda do sincronismo com a imagem.
} 
A homogeneidade é qualidade necessária para que os planos com som direto possam ser justapostos, constituindo uma sequência organizada por meio da montagem. Na perspectiva herdada do cinema clássico, as unidades constituintes de uma sequência devem ser sonoramente homogêneas para suavizar os cortes entre planos justapostos, corroborando na construção da ilusória impressão de continuidade espaço-temporal. O método de trabalho do som direto busca garantir que os planos captados em diferentes momentos da filmagem sejam homogêneos e que mantenham o registro da voz, com presença relativamente constante, isento de fontes sonoras indesejáveis, objetivando um alto grau de "editabilidade" dos planos sonoros.

Conforme aponta Michel Chion (2004, p. 18) a voz que carrega a palavra falada é o elemento central na trilha sonora cinematográfica, assim, a inteligibilidade da fala é determinante na qualidade do som direto, ocupando a principal posição nos procedimentos empregados pelo técnico de som. O método de trabalho do som direto busca preservar a fácil compreensão das palavras carregadas pelas vozes, por meio de um registro que mantenha: a fidelidade ao timbre original; a presença destacada em relação ao ambiente sonoro circundante; e a supressão de fontes sonoras secundárias.

A origem da centralidade da voz (da palavra falada) na trilha sonora cinematográfica, e consequentemente, na rotina de trabalho do técnico de som direto, será abordada no capítulo 2 (O filme sonoro e o nascimento do som direto), a partir das considerações trazidas por David Bordwell e Rick Altman, os quais relacionam o papel preponderante da fala na trilha sonora cinematográfica como resultado da incorporação do som, como um novo elemento narrativo, ao código de representação preexistente do cinema clássico norte-americano. A inteligibilidade das falas durante a exibição cinematográfica (provenientes da trilha sonora mixada) é resultante de uma cadeia de eventos eletroacústicos que atuam desde o seu registro no set até a sua reprodução nos alto-falantes da sala de cinema. Neste trabalho, centraremos a atenção nos fatores que interagem para a compreensão da fala no âmbito da captação do som direto.

A transição para o cinema sonoro determinou o desenvolvimento de novos procedimentos de realização que incorporaram o registro de som sincrônico ao processo de produção do sistema industrial norte-americano. As transformações das práticas de produção e o desenvolvimento de tecnologia específica para as necessidades da realização cinematográfica com som sincrônico são relatadas no capítulo 2, em que é destacada a disputa empresarial entre os estúdios como a principal força motriz para a transição do cinema 
silencioso para o cinema sonoro. São descritas as diferenças entre as tecnologias de registro do som sincrônico concorrentes no período de transição e são analisadas as características que determinaram a vitória do sistema de registro de som no filme (sound-on-film system) sobre o pioneiro sistema de gravação de som no disco (sound-on-disc system). Ainda no capítulo 2, tomando como base a análise realizada por Rick Altman (1992, p. 46-64), são apresentados os embates travados no seio da indústria norte-americana, envolvendo a incorporação do som no sistema de representação do cinema clássico que "naturaliza" as características técnicas/estéticas do som direto cinematográfico. Nos anos de transição, na constituição do código de representação do cinema clássico sonoro, os engenheiros de áudio, responsáveis pela implementação técnica do som, defendiam a necessidade da adequação das escalas entre a representação visual e a representação sonora, delineando um código que conflitava com as necessidades da representação clássica preexistente. Complementando o sintético apanhado sobre o desenvolvimento do método de trabalho do som direto, o capítulo 2 destaca os principais avanços tecnológicos (registro sonoro magnético; gravadores de som portáteis; microfones "sem fio"; tecnologia digital portátil multipista) que propiciaram novas ferramentas de trabalho e reformularam procedimentos na prática do registro sonoro sincrônico. Esses avanços permitiram o surgimento de formas alternativas de realização e conformaram novas estéticas cinematográficas.

O detalhamento das atividades práticas executadas pelo técnico de som direto no contexto da produção cinematográfica ficcional é apresentado no capítulo 3 (A prática de captação do som direto). Tomando como referência minha experiência pessoal como técnico de som na realização audiovisual brasileira e na bibliografia técnica especializada, o capítulo 3 descreve, passo a passo, a rotina padrão executada pelo profissional responsável pela qualidade do registro sonoro sincrônico. A apresentação e a discussão das atividades desenvolvidas na preparação da filmagem (análise técnica do roteiro; identificação das necessidades operacionais; tratamento acústico das locações; planificação das estratégias de "microfonação") e dos procedimentos de trabalho no set, durante a captação, permitem perceber o complexo processo de escolhas que conformam o método de trabalho do som direto. A aplicação sistemática dos procedimentos de trabalho e a interação com as demais áreas técnicas da realização determinam a qualidade do registro sonoro. Filmar com som direto é uma opção que demanda procedimentos adequados que contemplam a especificidade da matéria sonora. Assim, a discussão sobre o método de trabalho do som direto, desenvolvida no capítulo 3, se complementa com a análise de estratégias de direção que 
respeitam as necessidades técnicas para a captação de som e objetivam a qualidade do registro sincrônico.

O capítulo 4 (A captação de som nos longas-metragens Contra todos $e$ Antônia) detalha os procedimentos de trabalho empregados para a captação de som direto na realização dos filmes Contra todos e Antônia. As estratégias desenvolvidas para responder às complexas demandas de realização destes filmes exemplificam o contexto da prática profissional do técnico de som direto, revelando o dinamismo do método de trabalho. O detalhamento das propostas de realização (aspectos narrativos, condicionantes estéticas) de cada um dos projetos localiza as demandas específicas impostas pelos filmes. A descrição pormenorizada das estratégias de captação revela a atuação do técnico de som na planificação dos procedimentos de trabalho no desenvolvimento de soluções adequadas às necessidades específicas de cada realização. As sequências escolhidas para análise formam um painel variado e representativo das demandas de captação geradas pelos filmes. $\mathrm{O}$ aproveitamento integral do som direto captado nestes projetos é um indicador do acerto dos procedimentos empregados em suas realizações, valorizando a escolha deste material como elemento central de análise para a nossa pesquisa.

As considerações finais, por fim, trazem a reflexão sobre a dimensão criativa da atuação do profissional do som direto e sua contribuição na conformação técnica/estética da trilha sonora cinematográfica. 


\section{O FILME SONORO E O NASCIMENTO DO SOM DIRETO}

A captação do som sincronicamente à das imagens acontece tardiamente no processo de desenvolvimento histórico da chamada "produção industrial cinematográfica" ${ }^{3}$. As práticas relacionadas com a captação e o registro do som sincrônico são incorporados à rotina da estrutura industrial de realização das grandes companhias cinematográficas norte-americanas só a partir de 1927, com o advento do filme sonoro, aproximadamente uma década após a consolidação das práticas industriais de produção. Portanto, num momento em que as rotinas de produção já estavam solidamente estabelecidas e o estilo de representação do cinema silencioso definido. As particulares condições para a captação desse elemento que se integrava à imagem, modificando a forma de representação cinematográfica, determinariam profundas mudanças na infraestrutura técnica dos estúdios de filmagem e na reorganização dos procedimentos de set. As necessidades do som colidem com as atividades desenvolvidas pelas outras áreas técnicas envolvidas no processo de filmagem: o processo de realização do cinema sonoro exige silêncio para a captação no set.

Os profissionais que se responsabilizaram pela implantação dos sistemas, pelo desenvolvimento dos procedimentos e pela execução das tarefas de captação e registro do som eram originários da área do rádio. Investidos de "enorme poder" na estrutura hierárquica dos grandes estúdios, eles foram vistos pelos demais profissionais com um misto de "prestígio e desconfiança", pois exerciam o controle de uma "nova e misteriosa técnica" que era considerada, por alguns, como estranha à essência da arte cinematográfica e que, mesmo assim, determinava profundas alterações na prática da filmagem e na reordenação das relações profissionais do set. A incorporação tardia do som na realização cinematográfica determina, segundo Michel Chion (1992, p. 229), que "o engenheiro de som seja desde o princípio um homem isolado". Nos primeiros tempos do filme sonoro, o som captado sincronicamente, que posteriormente viria a ser chamado de som direto, era o único elemento constituinte das

\footnotetext{
${ }^{3}$ Resultante da atividade empresarial de conglomerados financeiros que atuavam na produção cinematográfica norte-americana no início do século passado, representados pelos grandes estúdios de Hollywood. As majors, como eram conhecidas, optavam pela economia de escala, utilizavam infraestrutura industrial e operavam num "sistema integrado" que não somente produzia e distribuía filmes, mas também administrava suas próprias cadeias de salas exibidoras. O "sistema de estúdio" de fazer cinema, que está intrinsecamente ligado ao desenvolvimento da indústria da realização cinematográfica, "surgiu durante a década de 10 e tomou forma nos anos 20 . Alcançou a maturidade nos anos 30, atingiu o auge durante o período da Segunda Guerra Mundial, para então entrar em constante declínio" (SCHATZ, 1988, p. 18).
} 
trilhas sonoras das películas cinematográficas, determinando o grau de importância atribuído aos ancestrais dos técnicos de som direto, os engenheiros de som.

Neste capítulo vamos traçar um panorama do período de transição apresentando: um pequeno resumo dos principais eventos que culminaram com a definitiva adoção do som cinematográfico pela indústria norte-americana; as características técnicas dos diferentes sistemas que concorreram na disputa pela hegemonia do som cinematográfico; as principais estratégias de realização desenvolvidas, considerando as necessidades trazidas pela captação de som direto e as características técnicas dos suportes de gravação adotados; o precoce debate sobre o modelo de representação do som direto realizado pelos técnicos de som durante os primeiros anos do cinema sonoro; e a discussão desenvolvida por David Bordwell sobre a lógica das relações entre imagens e sons que adaptaram o som às normas do cinema clássico norte-americano. Para além do período de transição apresentaremos, ainda, os principais avanços tecnológicos que paradigmaticamente definiram o método de trabalho empregado pelo som direto.

\subsection{A APOSTA EMPRESARIAL NO SOM SINCRÔNICO}

O advento do filme sonoro gerou mudanças no disputado mercado empresarial da produção cinematográfica, alterando o ranking das grandes empresas produtoras/exibidoras. O lançamento comercial, pela Warner Bros., do filme $O$ cantor de jazz, em 6 de outubro 1927, assumido como o momento inaugural do cinema sonoro mundial, potencializou o processo de transformação que estava em curso na indústria cinematográfica norte-americana. O sucesso financeiro da Warner Bros. com a realização e a exibição de filmes com som prégravado determinou que as principais empresas produtoras, que haviam adotado a postura de "esperar para ver", entrassem definitivamente na disputada corrida pelo controle do sonoro, o que significaria uma profunda alteração na maneira pela qual os filmes eram realizados. A

\footnotetext{
${ }^{4}$ O CANTOR de jazz. Direção de Alan Crosland. 1927. (88 min): P\&B,; 35 mm.

${ }^{5}$ Conforme aponta Douglas Gomery, as cinco mais importantes companhias (MGM, First National, Paramount, Universal e Producers Distributing Corporation) assinaram um acordo, em fevereiro de 1927, para atuar conjuntamente no processo de conversão para o filme sonoro. Em função da existência de diferentes tecnologias para o filme sonoro e sustentadas por uma lógica empresarial que apostava na padronização tecnológica como forma de evitar restrições na distribuição dos filmes, decidiram pela pesquisa conjunta e adoção em bloco de um mesmo padrão tecnológico para a conversão para o sonoro (GOMERY, 1985, p. 13).
} 
dimensão empresarial do advento do filme sonoro e as implicações na estrutura da indústria cinematográfica são apontadas por Thomas Schatz ao analisar a estratégia empregada pela Warner para competir com as companhias consideradas grandes e que dominavam o mercado realizador/exibidor na metade da década de 1920. Segundo ele:

A maior ironia na ascensão da Warner e na "revolução do cinema sonoro"
estava em a companhia ter desenvolvido o filme falado, não para diferenciar
seus produtos nem para revolucionar a realização cinematográfica, mas para
tentar equiparar-se às outras grandes. O circuito de exibição da Warner
consistia de umas poucas salas de primeira linha, e o som capacitaria a
companhia a oferecer os números musicais e de teatro que o público assistia
nas grandes salas de cinema de propriedade de Loew [MGM], da Fox e da
Paramount. (SCHATZ, 1991, p. 72).

Douglas Gomery (1985, p. 11) aponta a exibição realizada por Sam Warner ${ }^{6}$, em maio de 1925, como um momento importante para despertar nos principais executivos da Warner o interesse para o potencial empresarial do cinema sonoro. A exibição que contou com a gravação de cinco peças musicais revela aos executivos as possibilidades comerciais do uso do som nos filmes. Eles perceberam que se pudessem equipar os teatros recentemente adquiridos com sistemas de amplificação sonora e apresentar peças de vaudeville como parte integrante dos seus programas de exibição teriam condições de disputar o mercado com as grandes companhias. Segundo o autor,

[...] even Warners' smallest house could offer (1) famous vaudeville acts (on film), (2) silent features, (3) the finest orchestral accompaniments (on disc). Warners, at this point, never considered feature-length talking pictures, only singing and musical films. (GOMERY, 1985, p. 11).

Esta lógica empresarial que motivou o pesado investimento ${ }^{7}$ realizado pela Warner no processo que culminaria com a realização dos filmes com som gravados sincronicamente e na instalação dos sistemas de amplificação sonora nas suas salas de exibição não se relacionava,

\footnotetext{
${ }^{6}$ Um dos irmãos Warner, entusiasta da tecnologia dos sistemas de amplificação sonora, que estimulou a companhia a apostar na diferenciação técnica de seus produtos, foi o coordenador da produção dos primeiros curtas-metragens sonoros da Warner.

${ }^{7}$ No ano de 1925 a Warner conseguiu empréstimos no valor de 7 milhões de dólares que possibilitaram a expansão da cadeia de exibição e permitiram a aquisição da competitiva empresa Vitagraph Corporation, cujos estúdios seriam usados para a produção dos curtas-metragens sonoros da Vitaphone Corporation.
} 
portanto, primeiramente com o potencial artístico ou expressivo do novo meio, mas sim com a possibilidade comercial que se apresentava. Conforme reforça Schatz (1991, p. 72), relembrando as afirmações de Darryl Zanuck, o coordenador de roteiros da Warner naquele período:

\footnotetext{
Darryl Zanuck [...] haveria de lembrar-se, posteriormente, de que Harry Warner "pouco se importava com o que as personagens diziam na tela". Zanuck acrescentava: "Reconheço que eu também não me importava muito. Todos achávamos que Harry tinha razão ao dizer: 'Vocês se dão conta do que isso significa? De agora em diante, podemos oferecer a cada cidadezinha dos Estados Unidos uma orquestra com 110 componentes"”.
}

Em abril de 1926, a Warner deu o passo decisivo para a produção do filme sonoro por meio da associação com a Western Electric que, desde o início da década, detinha a tecnologia de amplificação sonora para grandes audiências e, a partir de 1924, capacitara-se a gravar e reproduzir sons com velocidade estável usando discos como suporte para o registro sonoro. A Warner Bros. e a Western Electric constituem a Vitaphone Corporation que tinha como objetivo a produção de filmes sonoros empregando a tecnologia do som no disco (sound-on-disc system) (GOMERY, 1985, p. 11-12). Conforme aponta Schatz (1991, p. 75), "[...] sob a égide dessa sociedade, Sam Warner produziu, no estúdio da Vitagraph de Nova York, centenas de curtas de um ou dois rolos - principalmente números de vauville com trilha sonora sincronizada".

A estreia comercial dos filmes sonoros da Warner ocorreu apenas quatro meses após o nascimento da Vitaphone Corporation. Em 6 de agosto de 1926, o sistema de reprodução sonora sincrônica foi revelado ao público num programa constituído por oito filmes curtos com apresentações musicais e com o longa-metragem Don $\mathrm{Juan}^{8}$. O longa-metragem era inicialmente um filme silencioso que recebeu acompanhamento sonoro feito por música e efeitos pré-gravados, reproduzidos sincronicamente a partir dos discos do sistema Vitaphone. Portanto, não era um filme falado, já que não haviam diálogos pré-gravados e o conteúdo das falas dos personagens era revelado por meio da tradicional estratégia do cinema mudo com cartelas escritas. Segundo Gomery (1985, p. 12), o acompanhamento musical sincrônico de Don Juan não causou grande comoção porque ele era simplesmente a substituição de uma orquestra ao vivo. O longa-metragem, um romance "capa espada" que, apesar de ser lançado com intensa campanha promocional, obteve pouca receptividade junto ao público, frustrando

\footnotetext{
${ }^{8}$ DON Juan. Direção de Alan Crosland. 1926. (110 min): P\&B,; 35 mm.
} 
a expectativa dos realizadores e obrigando a companhia a desacelerar o programa de conversão ao sonoro, que estava, conforme Schatz (1991, p. 77), em pleno processo de implantação com "a reforma das salas de exibição e do estúdio da Sunset, em Hollywood, onde quatro novos estúdios para a filmagem sonora estavam sendo construídos".

As dúvidas em relação à aceitação do filme sonoro pelo público foram completamente dirimidas a partir do espantoso sucesso comercial ${ }^{9}$ obtido pelo longa-metragem $O$ cantor de jazz, lançado em outubro de 1927. O primeiro longa-metragem falado é na verdade um filme híbrido, pois a despeito do imenso esforço, realizado pela Warner, de colocar no mercado um filme de longa duração que envolvia canções e alguns diálogos pré-gravados exibidos em sincronia com as imagens, $O$ cantor de jazz era impregnado pela forma cinematográfica do filme silencioso. "O enredo ${ }^{10}$ era puro melodrama, a representação carregada de pantomima e gesticulação excessiva" (SCHATZ, 1991, p. 77) e grande parte dos diálogos revelados por meio de intertítulos. Porém, mesmo com esse hibridismo, a recepção foi um imenso sucesso, conforme aponta Schatz (1991, p. 79) ao referir-se à reação do público que

[...] ficava encantado com o filme, principalmente quando a estrela de vaudeville $\mathrm{Al}$ Jonson lançava à orquestra, aos companheiros de cena e até ao público suas tiradas características. "C'mon, Ma - listen to this!" [Mãe, escute isto!], irrompia o dinâmico Jolson antes de entrar em "Blue skies". Os poucos diálogos causavam tanto impacto no público quanto a canção que se seguia.

A aceitação do público ratificou o acerto da aposta empresarial da companhia, impulsionando o projeto da Warner na passagem para o sonoro que seria executado num curto espaço de tempo. Segundo Schatz (1991, p. 79):

Poucas semanas após o lançamento do filme, completou-se a construção do último dos quatros estúdios sonoros, bem como o projeto de conversão total para esse sistema, a ser executado no período de um ano. Os novos estúdios tinham cerca de 27 por 45 metros e contavam com isolamento acústico especial, cabines móveis para as câmeras e cabines de vidro para a gravação

\footnotetext{
${ }^{9}$ O custo de produção do filme foi de 500 mil dólares, a mais cara realização já feita pela Warner, porém o retorno obtido nas bilheterias foi de 3 milhões de dólares (SCHATZ, 1991, p. 77-79).

${ }^{10}$ O Cantor de jazz conta a história de Jakie Rabinowitz, interpretado por $\mathrm{Al}$ Jonson, que rompe com as tradições familiares judaicas ao seguir carreira como cantor popular. Jackie, que herdaria a função de Chazan ocupada pelo pai, opta pelo canto artístico, sendo expulso de casa. Mesmo alcançando sucesso profissional, carrega o conflito pela separação com a família que é resolvido, apenas no final da narrativa, ao obter perdão do pai moribundo.
} 
de sons. Deu-se de imediato o início dos trabalhos [...] para a produção dos filmes totalmente falados. Em dezembro de 1927, a Vitaphone lançava Salomon's children, filme de "dois-rolos" inteiramente falado, e, em julho de 1928, a Warner Bros. vinha com The lights of New York", outro "doisrolos", da Vitaphone esticado pelo diretor Bryan Foy para a duração de um modesto longa-metragem (57 minutos). Isso elevou os custos de produção de 21 mil dólares para 75 mil dólares, mas The lights of New York primeiro longa-metragem totalmente falado, obteve uma renda de bilheteria superior a 1 milhão de dólares.

Em pouco mais de um ano, no final de 1928, a empresa concluiria a conversão para o sonoro e toda a produção da Warner, curtas e longas-metragens, seria constituída por filmes falados (talkies). A estratégia expansionista da empresa, com a aposta no sonoro, se mostraria correta, resultando na ampliação significativa da rede de distribuição/exibição e na aquisição do controle acionário de uma das grandes empresas de produção e distribuição, a First National. Em 1929, a Warner viria a se tornar a mais lucrativa empresa entre as companhias de cinema norte-americanas (GOMERY, 1985, p. 15).

A Fox Film Corporation, fundada em 1915 por Willian Fox, também apostou na realização do filme sonoro como parte do abrangente plano de expansão empresarial da companhia, que buscava ocupar maior espaço no disputado mercado cinematográfico norteamericano. Em 1925, a Fox Film havia iniciado o processo de expansão por meio de fortes investimentos financeiros ${ }^{12}$ que havia envolvido, entre outros aspectos, a estruturação de uma rede de salas de exibição e a ampliação das atividades de produção do jornalismo cinematográfico (newsreel).

Em 1926, Courtland Smith, presidente da divisão de jornalismo cinematográfico da Fox (Fox Newsreels), fechou um acordo com Theodore Case ${ }^{13}$ para a produção do filme sonoro. Smith acreditava que o controle sobre a produção do cine-jornalismo sonoro pudesse impulsionar a marca Fox para a vanguarda da indústria cinematográfica (GOMERY, 1985, p. 16). A tecnologia apresentada por Theodore Case, desenvolvida a partir dos experimentos

${ }^{11}$ LUZES de Nova Iorque. Direção de Bryan Foy. 1928. 1 filme (57 min): son., P\&B,; 35 mm.

${ }^{12}$ Segundo Gomery, a Fox Film Corporation levantou cerca de seis milhões de dólares por meio da venda de ações da empresa, iniciando o processo de expansão que envolveu investimentos na ampliação da rede de exibição por intermédio da construção de novas salas, no aumento dos orçamentos para a produção de longas-metragens e na expansão das atividades no jornalismo cinematográfico (GOMERY, 1985, p. 12).

${ }^{13}$ Theodore Case, um pesquisador independente autofinanciado, situado ao norte do estado de New York, aprimorou a válvula de amplificação denominada de Thalofide Cell e incorporou o seu invento em sistemas de gravação de som. Após conhecer o sistema desenvolvido por Lee De Forest (o Phonofilm) dedicou-se à pesquisa do registro sonoro em película, apresentando ao mercado, em 1925, uma versão melhorada daquele sistema. 
inicialmente realizados por Lee De Forest ${ }^{14}$, baseava-se no registro sonoro feito diretamente na película cinematográfica (sound-on-film technology).

Poucos meses depois, em junho de 1926, foi realizada por Courtland Smith uma apresentação do sistema para Willian Fox, o presidente da companhia, que imediatamente reconheceu o potencial empresarial da nova tecnologia e determinou a criação da Fox Case Corporation, objetivando a produção do filme sonoro. Embora Smith pressionasse pela experimentação do sonoro nos cines-jornais, o presidente da companhia, mantendo uma posição conservadora, determinou que os esforços de produção fossem orientados para a realização de curtas com apresentações musicais e pequenas peças de vaudeville, imitando a estratégia desenvolvida pela Warner. O evento que divulgou o novo sistema sonoro, batizado de Movietone (Movietone system), foi realizado em 24 de fevereiro de 1927 com uma inteligente e eficiente estratégia publicitária. Conforme relata Gomery:

At 10:00 in the morning fifty reporters entered the Fox Studio near Times Square, and were filmed using the miracle of Movietone. Four hours later these representatives of the press-corps saw and heard themselves as part of a private screening. In addition, Fox-Case presented several vaudeville sound shorts: a banjo and piano act, a comedy sketch, and three songs by the popular cabaret performer, Raquel Meller. The strategy worked. Unanimous favorable commentary issued forth: the future seemed bright (GOMERY, 1985, p. 17).

Diante da recepção positiva, a Fox iniciou a instalação dos sistemas de amplificação de áudio em vinte seis das suas principais salas de exibição. Os sistemas foram fornecidos pela Electrical Research Products Incorporation (ERPI), subsidiária da Western Electric, criada para driblar o contrato de exclusividade firmado com a Warner, ampliando a participação e as possibilidades de lucro da Western Electric no emergente mercado do cinema sonoro.

Sabendo da escassez de artistas populares para a realização dos curtas musicais sonoros da Fox, em decorrência dos contratos de exclusividade que a Warner havia

\footnotetext{
${ }^{14} \mathrm{O}$ sistema desenvolvido por Lee De Forest foi apresentado na New York Electrical Society em 4 de abril de 1923. O Phonofilm, descrito por De Forest como uma simples fotografia da voz no filme cinematográfico, era na verdade um dos maiores avanços tecnológicos desde a invenção da válvula de amplificação (audion amplifier tube), desenvolvida pelo próprio De Forest, em 1907. A apresentação pública, ocorrida duas semanas depois, não provocou grandes reações da audiência, provavelmente em função das cenas exibidas serem acompanhadas por música não-sincrônica que não despertou grande interesse pelo sistema.
} 
estabelecido pouco antes com os principais artistas da época para a produção dos curtas da Vitaphone Corporation, Smith insistia, junto a Willian Fox, que a empresa deveria canalizar os esforços de produção na realização dos cines-jornais sonoros, oferecendo uma alternativa exclusiva e economicamente viável às apresentações da Warner e conquistando uma fatia do mercado cinematográfico desocupada até aquele momento. De acordo com Gomery (1985, p. 17), para Smith, iniciar as operações com filme sonoro por meio dos cines-jornais seria um método lógico para aperfeiçoar gradualmente as novas técnicas de câmera e edição envolvidas na realização do sonoro. Percebendo que o espaço de mercado, apontado por Smith, deveria ser ocupado, Willian Fox determinou que os esforços de implantação do sonoro seriam primeiramente dirigidos à produção dos cines-jornais.

A primeira exibição pública de um cine-jornal produzido pela Fox Newsreel ocorreu no final de abril de 1927, no Roxy Theatre ${ }^{15}$, em Nova York, com a apresentação de um filme, com quatro minutos de duração, que revelava os cadetes da academia militar de West Point em marcha. Douglas Gomery (1985, p. 18) aponta que a despeito da ausência de publicidade, a projeção desse cine-jornal provocou uma resposta extremamente entusiasmada por parte da imprensa.

Em maio de 1927, ocorreu o evento de maior repercussão que consolidou o espaço para os cines-jornais sonoros da Fox Film e colocou a empresa em um patamar mais elevado no mercado produtor: o filme que acompanhava a decolagem de Charles Lindberg para Paris em seu projeto de cruzar o Oceano Atlântico. Conforme o relato de Douglas Gomery, esse filme criou um dos mais emblemáticos eventos do jornalismo da década de 1920:

At 8:00 A.M. on May 2, 1927, Charles Lindbergh departed for Paris. That evening Fox Movietone News presented footage of the takeoff - with sound - to a packed house at the Roxy theater. Six thousand persons stood and cheered for nearly ten minutes. The press saluted this new motion picture marvel and noted how it had brought alive the heroics of the "Lone Eagle" (GOMERY, 1985, p. 18).

A opção da Fox Film pela produção dos cines-jornais sonoros se revelou uma estratégia empresarial vitoriosa, coroando o projeto de expansão, iniciado em 1925. No final de 1927, a Fox Film padronizou a distribuição dos Fox Movietones News em todas as salas da

\footnotetext{
${ }^{15}$ O Roxy Theatre era uma das salas de exibição considerada de primeira linha com capacidade para quase 6000 lugares que havia sido recentemente incorporada à cadeia de exibição da Fox Corporation e adaptada para projeção sonora.
} 
sua cadeia de exibição com o lançamento de um filme por semana com 10 minutos de duração. Além disso, a Fox Newsreels ampliou seu quadro funcional permanente e criou uma rede mundial de correspondentes.

No início de 1928, a companhia anunciaria a total conversão para o sistema sonoro com a produção de cines-jornais, curtas e longas-metragens. No início desse ano, os cinesjornais sonoros potencializariam o processo de expansão da Fox Film e dividiriam com os curtas sonoros e os longas-metragens parcialmente falados da Warner a principal demanda do público de cinema. O pioneirismo na conversão para o cinema sonoro determinaria uma lucrativa vantagem, apesar de temporária, da Warner e da Fox Film sobre os cinco grandes estúdios que haviam decidido, no início de 1927, esperar pelo menos um ano para realizar a passagem para o sonoro.

Concomitante ao processo desenvolvido pela Warner e Fox, a Radio Corporation of America $(\mathrm{RCA})^{16}$ se lançou na disputa pelo valioso mercado do fornecimento de tecnologia para a realização do filme sonoro com o desenvolvimento de um sistema próprio de registro de som. Em fevereiro de 1927 a apresentação à imprensa de curtas-metragens com acompanhamento musical pré-gravado, empregando o sistema batizado de Photophone (sound-on-film), foi bem recebida com elogios para a perfeita sincronização e para a qualidade do volume e da tonalidade do som do programa exibido (GOMERY, 1985, p. 20). A RCA, que ao longo da década de 1920 desenvolveu tecnologia ${ }^{17}$ para a realização de filmes com som sincrônico, passou a disputar o efervescente mercado criado pela decisão das majors de iniciar a conversão para o sonoro.

Em maio de 1928, diante do inelutável sucesso dos filmes falados, as cinco majors ${ }^{18}$ decidiram pela conversão em bloco para o sonoro, padronizando a tecnologia e os

${ }^{16}$ A RCA era uma empresa subsidiária da General Electric and Westinghouse (GE) dedicada ao desenvolvimento e controle de produtos e patentes desenvolvidas para sistemas de rádio transmissão.

${ }^{17} \mathrm{O}$ desenvolvimento da tecnologia da RCA teve como marco inicial o lançamento do PalloPhotophone, em dezembro de 1921, um sistema de registro sonoro em película monocromática de 35 $\mathrm{mm}$ de largura, sem perfurações que registrava até 12 pistas de áudio usado na produção radiofônica. Entre 1922 e 1923, o sistema é adaptado para gravar uma pista de $1,5 \mathrm{~mm}$ na lateral da película, liberando espaço para a imagem. As pesquisas são orientadas para o desenvolvimento de um reprodutor de som que pudesse ser acoplado aos projetores de cinema e paralelamente para a criação um novo alto-falante que seria empregado nas salas de exibição. No final de 1923, o sistema estava praticamente completo, porém o desenvolvimento do projeto é suspenso em função da suposta falta de interesse empresarial em relação ao filme sonoro. Em 1926, após o incontestável sucesso da Warner com os filmes sonoros, as pesquisas da RCA foram retomadas, culminando com o lançamento público do sistema rebatizado para Photophone no início de 1927 (GOMERY, 1985, p. 17-18).

${ }^{18}$ MGM, First National, Paramount, Universal e Producers Distributing Corporation. 
procedimentos de produção. Após um habilidoso processo de negociação ${ }^{19}$, envolvendo a ERPI e RCA - as duas empresas detentoras da tecnologia para o registro e reprodução do som sincrônico -, as "cinco grandes" firmaram acordo com a ERPI, que pouco tempo antes havia também desenvolvido a tecnologia do sound-on-film, para a conversão global dos estúdios. $\mathrm{O}$ processo de conversão levou um pouco mais de um ano para ser efetivado ${ }^{20}$.

De acordo com Bordwell (1997a, p. 332), a eficiência no processo de transição dos grandes estúdios para o sonoro só foi possível graças à política de cooperação estabelecida entre as companhias e à padronização dos processos técnicos, ambas coordenadas pela Academy of Motion Pictures Arts and Sciences (AMPAS) ${ }^{21}$, que definiu as principais demandas de produção e estabeleceu as relações com os fabricantes de equipamentos e as associações profissionais para o desenvolvimento de soluções integradas num padrão cooperativo sem precedentes na história da indústria cinematográfica norte-americana. Segundo o autor, o aumento da complexidade técnica e dos custos dos sistemas empregados na realização do filme sonoro obrigou a reestruturação do quadro funcional dos estúdios e uma maior integração com as empresas fornecedoras de material sensível e equipamentos.

Nesse processo de reorganização dos procedimentos de filmagem para o sonoro, os estúdios passaram a contar, entre seus quadros, com engenheiros, projetistas e técnicos especializados que ampliaram e sistematizaram os processos de investigação de novos equipamentos. Os protótipos desenvolvidos em suas oficinas eram encaminhados aos fabricantes para aprimoramento e produção em série (o suporte móvel para microfone, o boom, fabricado pela empresa Mole-Richardson exemplificava esta nova relação). Eles sistematizaram a divulgação das informações sobre o desenvolvimento e o emprego de novos equipamentos, por meio dos boletins da Academia e das publicações das entidades

19 A escolha da empresa fornecedora da tecnologia para a conversão sonora, além de variáveis técnicas, foi determinada por questões empresariais relacionadas ao controle de patentes, valor dos royalties e opção de contratação. As majors, aproveitando-se da força do seu monopólio, pressionaram para a obtenção das condições mais favoráveis aos seus interesses. Gomery $(1985$, p. 20) revela que a inflexível posição por um acordo de licença global determinou a exclusão da RCA e a opção pela ERPI que cedeu às pressões, celebrando licenças individuais com os estúdios.

${ }^{20}$ Em maio de 1929, exatamente um ano após o contrato com a ERPI, a Paramount passou a produzir exclusivamente os filmes falados (the talkies), e em setembro do mesmo ano, o processo de conversão total para o sonoro se completava para as companhias MGM, Fox, RKO, Universal e United Arts (GOMERY, 1985, p. 22).

${ }^{21}$ A AMPAS foi fundada em janeiro de 1927, por Loius B. Mayer, com o objetivo declarado de "melhorar a qualidade artística do cinema", porém cumpria um importante papel no controle das disputas trabalhistas envolvendo os estúdios. A Academia foi constituída com cinco categorias profissionais: atores, diretores, roteiristas, técnicos e produtores (SCHATZ, 1985, p. 113). 
profissionais, tais como a Society of Motion Picture Engineers (SMPE) ${ }^{22}$ e a American Society of Cinematographers (ASC) ${ }^{23}$.

Conforme apresenta Bordwell (1997a, p. 332), o período de 1928 a 1930 testemunhou uma intensa expansão do setor dos serviços técnicos ligados à produção cinematográfica, resultante das demandas originadas pelos estúdios no processo de conversão para o sonoro:

Kodak fundó el Eastman Service Building en Santa Monica Boulevard en 1929; estas instalaciones estaban equipadas con un salón, biblioteca de referencia, laboratorio de pruebas y sala de proyección privada, todo ello a disposición de los operadores de cámara. Algo más tarde, aquel mismo año, Du Pont dotó a su edificio de Hollywood con un pequeño plató que permitiría a los operadores de cámara hacer pruebas. Mole-Richardson, en plena expansión con la adopción a escala general de la iluminación incandescente, se mudó a unas instalaciones mayores en 1928 [...] y para junio de 1930 daba empleo a cincuenta ingenieros, técnicos y personal de oficina. En 1929, la Mitchell Camera Company abrió una fábrica de mayor tamaño.

A despeito do grande desenvolvimento das companhias de serviços, o controle do processo foi centralizado pela AMPAS, academia que representava os estúdios. Conforme Bordwell (1997a, p. 332-333), a Academia instituiu o Producers-Technicians Committee com o objetivo de articular e resolver problemas técnicos, operando a execução do programa de conversão padronizada para o sonoro. No trecho abaixo, o autor destaca um dos importantes papeis desempenhados pelo Comitê:

Dirigido por Irving Thalberg de MGM, este comité de importancia crucial estaba formado por productores de los estudios más importantes y por representantes de organizaciones como Technicolor, ERPI, RCA y SMPE. Entre 1929 y 1931, el comité ofreció una serie de cursos que establecieron una serie común de procedimientos de grabación siguiendo [...] 'una trayectoria non competitiva'. En mayo de 1930, 900 empleados de los estudios habían terminado estos corsos (BORDWELL, 1997a, p. 333).

A atuação do Comitê na padronização dos procedimentos de produção, continua o autor, foi iniciada pela determinação das questões mais urgentes que precisariam ser

\footnotetext{
${ }^{22}$ A SMPE foi fundada em 1916 congregando os engenheiros área da indústria cinematográfica. Atualmente é denominda como Society of Motion Picture and Television Engineers (SMPTE).

${ }^{23}$ A ASC, fundada em 1919, congrega os diretores de fotografia da indústria cinematográfica norteamericana é uma entidade profissional, educativa e cultural.
} 
resolvidas na passagem para o sonoro e que estavam diretamente ligadas às condições acústicas para a captação do som, começando a definir os padrões estéticos do cinema sonoro. Eram elas: silenciar a lâmpada de arco voltaico, silenciar a câmera cinematográfica e criar materiais para isolar acusticamente os estúdios.

A partir da determinação dos principais problemas da passagem para o sonoro, o Comitê orientou os esforços junto aos fabricantes e entidades profissionais em busca de soluções que mantivessem a eficiência do sistema, permitindo incorporar o filme sonoro (the talkies) aos padrões de produção preexistentes e garantindo uma transição controlada sem riscos de perturbações de ordem financeira.

\subsection{SISTEMAS DE GRAVAÇÃO E REPRODUÇÃO SINCRÔNICOS}

Se o advento do cinema sonoro pode ser percebido como resultante da competição empresarial entre as companhias produtoras que resultou na reordenação das práticas produtivas na indústria cinematográfica, os sistemas tecnológicos que suportam o cinema sonoro também refletem esta disputa. Durante o período de transição para o sonoro coexistiram diferentes tecnologias que competiram pelo mercado da gravação e reprodução do filme sonoro. Nos primeiros anos do sonoro, os avanços tecnológicos que determinaram a substituição ou aprimoramento dos sistemas empregados visaram a superação de limitações técnicas e suas consequências estéticas. A seguir descreveremos as principais características dos sistemas empregados no período de transição para o cinema sonoro.

\subsubsection{Sistema de som no disco (sound-on-disc system) - Vitaphone}

Como vimos anteriormente, o vitaphone desenvolvido pela Vitaphone Company foi o primeiro sistema de gravação e reprodução de som cinematográfico sincrônico que obteve sucesso comercial. A Vitaphone Company garantia a exibição dos filmes com som prégravado para grandes audiências, graças à tecnologia da amplificação sonora consolidada, desde o início da década de 1920, pela sua associada a Western Electrics.

No Sistema Vitaphone a gravação do som era realizada por uma cabeça de corte eletromecânica com uma agulha que vibrava conforme as variações elétricas recebidas e 
esculpia um sulco num disco matriz, imprimindo uma representação das ondas sonoras. A partir da matriz gravada eram feitas as cópias para a exibição. Os discos utilizados tinham 12 ou 16 polegadas de diâmetro (aproximadamente $30 \mathrm{ou} 40 \mathrm{~cm}$ ) e rodavam a uma velocidade de 33 1/3 rotações por minuto, permitindo gravações com no máximo 7 e 9 minutos de duração, respectivamente. A gravação era feita em uma única face do disco e era realizada do centro para fora, num equipamento chamado "torno de gravação" (recording lathe $)^{24}$, como vemos representado na Foto 1.

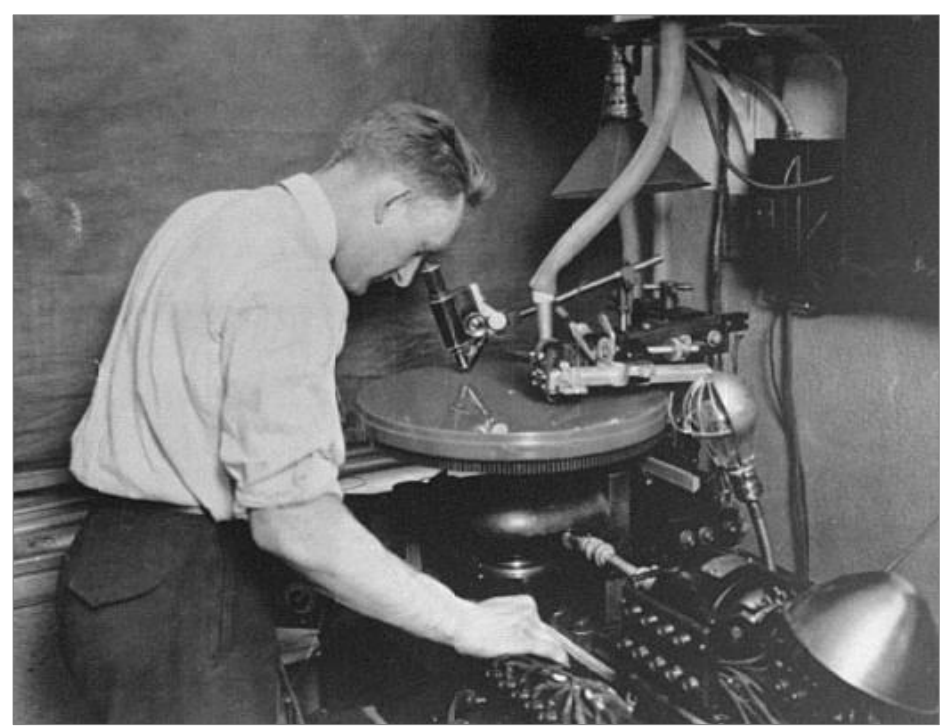

Foto 1 - Gravador de som do sistema Vitaphone (recording lathe).

O sistema para a exibição era constituído por um projetor de filmes integrado a um toca-discos, como pode ser visto na Foto 2. O sincronismo do sistema era obtido mecanicamente com a utilização de um único motor que transmitia, ao prato do toca-discos e ao sistema de arraste da película, um mesmo pulso, determinando, dessa forma, a correspondência das velocidades dos dois suportes (HANDZO, 1985, p. 385). Nas salas de projeção, o sinal de áudio captado pela agulha do toca-discos era amplificado eletronicamente e reproduzido pelos alto-falantes dispostos no auditório. O sistema reproduzia frequências sonoras entre 50 e $5.000 \mathrm{~Hz}$, aproximadamente.

\footnotetext{
${ }^{24}$ No recording lathe a matriz é sulcada pela cabeça de corte denominada disk-cutting-heads.
} 


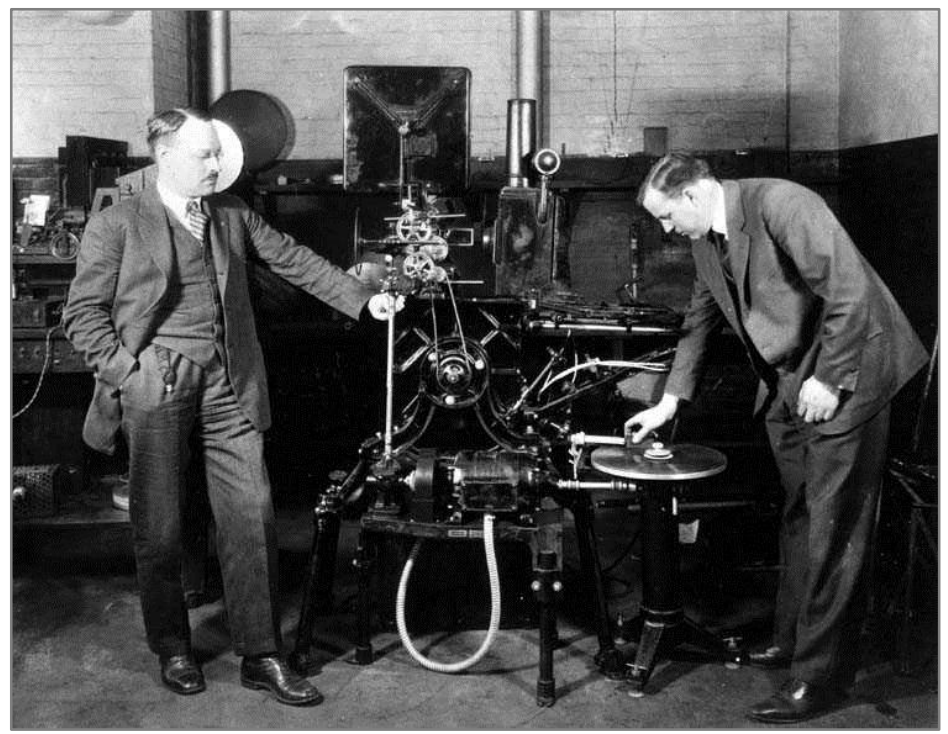

Foto 2 - Projetor de imagens integrado mecanicamente ao toca-discos.

Stephen Handzo (1985) aponta que na época do seu lançamento, a qualidade da reprodução sonora alcançada pelo sistema com disco era maior do que a do sistema concorrente (sound-on-film). No entanto, as limitações técnicas do Vitaphone se evidenciaram a medida em que a Warner passou a produzir longas-metragens com diálogo sincrônico (the talkies). O perfeito sincronismo alcançado em laboratório se mostrava menos confiável no cotidiano das exibições. Nos filmes de longa duração, as trocas de rolo eram momentos potencialmente críticos para o sincronismo, pois dependia da habilidade e da atenção dos projecionistas que, após o "carregamento" do rolo de imagem, com a colocação do fotograma "start" na abertura do projetor, precisavam posicionar a agulha do toca-discos exatamente na marca de início do disco correspondente (próxima ao sulco mais interno) para então iniciar a projeção. O perfeito sincronismo labial, exigência fundamental para a representação naturalista, só era obtida com a ação cuidadosa do projecionista que, além de configurar corretamente o inicio da projeção de cada rolo, necessitava realizar pequenos ajustes na velocidade do prato giratório para eliminar a imprecisão inicial da partida do rolo. Para essa função, o toca-discos era equipado com um controle da velocidade do prato giratório que permitia ao projecionista o aumento ou a diminuição da rotação com a projeção em andamento. Além dessa dificuldade, que gerava inúmeros problemas de sincronismo, os discos eram frágeis e apresentavam baixa durabilidade, suportando em torno de apenas 24 reproduções, resultado do desgaste produzido pelo atrito da agulha no sulco de gravação (HANDZO, 1985, p. 386). 
O trabalho na cabine de projeção era essencial à eficiência do sistema e exigia extremo cuidado dos projecionistas, pois qualquer esbarrão no toca-discos durante a projeção poderia ocasionar o pulo da agulha e a consequente perda de sincronismo, ou ainda, se a cópia de exibição sofresse uma avaria, com a perda de alguns fotogramas, aquele trecho deveria ser compensado com o acréscimo de uma "ponta preta", com igual número de fotogramas, para a manutenção do sincronismo.

A gravação dos discos do sistema Vitaphone era contínua e não permitia edição do material gravado, obrigando que as tomadas sonoras fossem realizadas sem interrupção. A tomada era feita do começo ao final de um disco, e a duração da gravação era determinada pelo tamanho do disco empregado. Se um ator errasse um trecho do texto ao longo da tomada, a gravação era inviabilizada e a matriz era descartada. A impossibilidade de edição do disco determinava que o som governasse a imagem (HANDZO, 1985, p. 386). A necessidade técnica da realização da tomada sonora sem interrupção impedia a aplicação do método tradicional de filmagem: decupagem da cena em vários planos, com diferentes enquadramentos, para posterior construção da unidade da ação por meio da montagem (multiple takes method). Um dos alicerces da construção da narração do estilo clássico ficava restrito por uma característica técnica do cinema sonoro baseado no sound-on-disc. A solução empregada para driblar esta restrição foi o emprego de múltiplas câmeras que filmavam simultaneamente, com diferentes enquadramentos, as cenas sonoras, permitindo a preservação do padrão narrativo pré-estabelecido durante o período silencioso (CRAFTON, 1997, p. 245). Esta estratégia não recupera completamente o padrão desenvolvido no silencioso, pois como aponta Eduardo Santos Mendes (2000, p. 9), a estratégia de filmar simultaneamente o plano geral, planos próximos e planos de cobertura

[...] não ampliava em muito as possibilidades de montagem da imagem. Como o disco com o som direto da cena era usado como o guia do processo de montagem e não era possível alterar o tempo interno entre as falas, o trabalho de montagem da imagem limitava-se a inserir os planos de cobertura no "master-shot", trocando a quantidade exata de fotogramas de um plano pela do outro.

Outra tentativa de minimizar a impossibilidade de edição física do som gravado no disco foi a criação de um sistema integrado que permitia ligar "até nove fonógrafos simultaneamente (oito reprodutores e um gravador)" criando o primeiro sistema de mixagem de som para cinema. Com este sistema era possível fazer a mistura do material sonoro de 
diferentes planos, garantindo a sincronia e permitindo a captação de planos sonoros com curta duração (MENDES, 2000, p. 9).

Apesar do enorme sucesso dos talkies produzidos com o sistema Vitaphone, os insolúveis problemas decorrentes das características técnicas e a opção empresarial dos grandes estúdios pela padronização do sistema sonoro determinaram que no início da década de 1930 o Vitaphone estivesse praticamente fora de uso, conforme relata Donald Crafton (1997, p. 146):

\begin{abstract}
With compatibility between optical system assured, the changeover from disk to sound-on-film was very rapid. Until mid-1928, most sound films were recorded and played back on ERPI system. The second half of 1928 and the beginning of 1929 was a time of transition. Most studios switched to sound-on-film registration, but in theaters playback was mainly on disk. By the end of 1930, however, the majority of theaters projected Movietone, Photophone, or an off-brand optical sound track. [...]

In the first months of 1929, the most important distributors, Paramount, MGM, and United Artists, announced that they would discontinue disc releases. Recording the primary sound track on disc was a practice that, except at Warners and First National, had failed to catch on in Hollywood.
\end{abstract}

\title{
2.2.2 Sistema de som no filme (sound-on-film system)
}

Antes do sucesso do Vitaphone, a tecnologia do sistema de registro de som em película já era conhecida. Os resultados exibidos por Lee De Forest, entre 1923 e 1924, mostraram-se tecnicamente adequados. $O$ registro sonoro impresso na película cinematográfica é denominado como "som óptico". O sincronismo entre a imagem e a trilha sonora no sound-on-film system é absoluto, pois nesse sistema, som e imagem compartilham o mesmo suporte físico: a película cinematográfica.

No registro do som no disco, a energia sonora é transformada em energia elétrica e posteriormente convertida em energia mecânica, que é impressa nas modulações esculpidas nos sulcos dos discos. O sistema óptico de registro de som também se baseia na conversão de energia, porém neste sistema, a energia elétrica resultante da conversão da energia sonora é transformada em energia luminosa, que é transcrita sobre a película cinematográfica. Duas diferentes técnicas para o registro do som na película disputaram o mercado do som cinematográfico na transição para o sonoro: o som óptico de densidade variável e o som óptico de área variável. 
O óptico de densidade variável, denominado comercialmente como "Movietone", foi desenvolvido pela associação entre a Fox e a ERPI. Neste sistema uma válvula de luz, aprimorada pela Western Electric, projetava sobre o negativo virgem pulsos luminosos que correspondiam à variação da intensidade e da frequência da corrente elétrica que trafegava pela válvula. Como resultado da pulsação luminosa, era inscrita, entre a lateral dos fotogramas e as perfurações do negativo, uma sucessão de linhas horizontais escuras que variavam na intensidade e na frequência, correspondendo às modulações das ondas sonoras captadas pelo microfone, conforme explica Stephen Handzo (1985, p. 387), ao descrever o funcionamento da "válvula de luz" da Western Electric:

\begin{abstract}
A microphone converts sound waves into electrical impulses; putting the speech current through a narrow loop of wire in a magnetic field will cause the wire to vibrate closer or farther away from itself according to the applied electrical waveform ("electromagnetic vocal chords"); a light beam shining through the fluctuating gap between the wires would be modulated in intensity, thus "writing" sound information on unexposed film in motion.
\end{abstract}

No negativo revelado, a informação sonora aparecerá como linhas pretas sobre um fundo claro. Na cópia de exibição, a aparência da trilha sonora óptica com densidade variável assemelha-se ao padrão visual do código de barras universal. A frequência do som é representada pela distância entre as linhas horizontais e a intensidade do som pelo grau de negrume ou transparência (densidade) das linhas, como representado na Figura 1. 

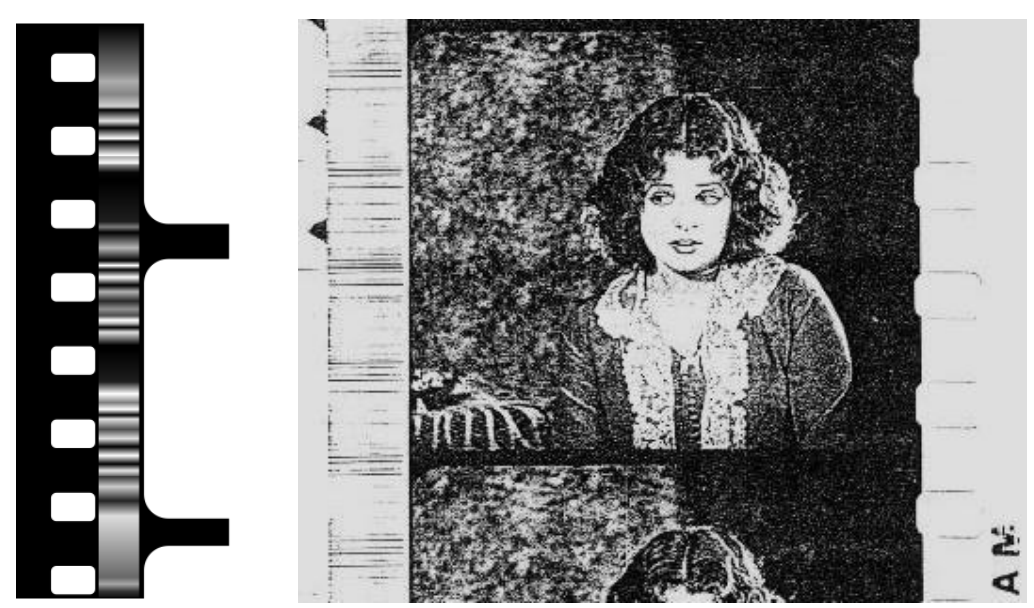

Figura 1 - Representação gráfica e fotograma com som óptico de densidade variável. Trilha sonora impressa entre a lateral dos fotogramas e as perfurações.

No óptico de área variável, o Photophone desenvolvido pela RCA, a conversão da energia elétrica que trafega pelo sistema é realizada por meio da ondulação de um facho de luz que desenha, sobre o negativo virgem e em movimento, a modulação da onda sonora. A inscrição resultante é análoga às variações da pressão acústica captadas pelo microfone, assemelhando-se à representação gráfica do som encontrada nos softwares de edição atualmente empregados na pós-produção audiovisual. A ondulação do facho de luz é obtida por meio da reflexão de uma fonte luminosa em um espelho rotativo movimentado por um galvanômetro $^{25}$ que responde às variações da corrente elétrica. A amplitude da onda desenhada no negativo corresponde à intensidade, e a distância entre cada onda representa literalmente a frequência do som: quanto mais próximas, maior a frequência quanto mais distantes, menor a frequência. Na Figura 2 vemos um exemplo da aparência do registro do som óptico de área variável.

\footnotetext{
${ }^{25}$ É um instrumento usado para indicar a presença de correntes elétricas de baixa intensidade por meio de um dispositivo mecânico que é posto em movimento pela ação de forças eletromagnéticas produzidas pela variação de corrente.
} 

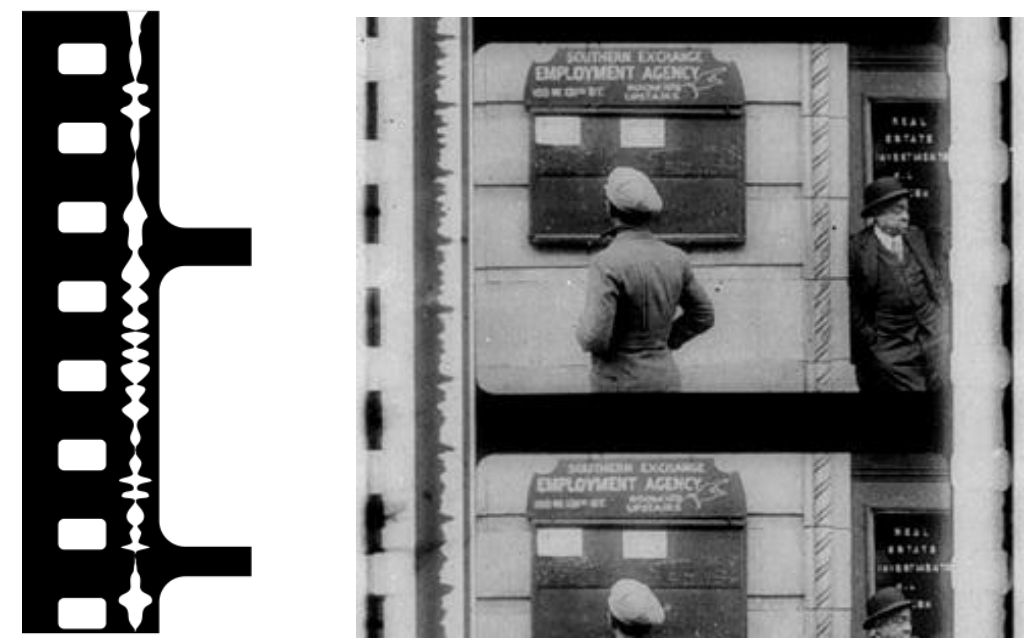

Figura 2 - Representação gráfica e fotograma com som óptico de área variável. $\mathrm{Na}$ representação gráfica, óptico duplex de área variável. No fotograma, óptico unilateral de área variável.

O sistema adotado em bloco pelos estúdios para o registro dos sons na produção dos talkies foi o óptico de densidade variável comercializado pela ERPI, o Movietone. Das grandes companhias, apenas a Radio-Keith-Orpheum (RKO) ${ }^{26}$ e a Warner, após o desuso do Vitaphone, optaram pelo sistema da RCA, o Photophone. Segundo Handzo (1985, p. 388), inicialmente o óptico de densidade variável apresentava maior inteligibilidade das falas. Ao ser comparado ao óptico de área variável, que era mais suscetível à distorção do sinal, causada pelas consoantes oclusivas que geravam a saturação do registro óptico, este problema foi resolvido com o emprego de circuitos eletrônicos de limitação do sinal elétrico (limitadores). A partir de então, o sistema óptico de área variável tornou-se o preferido por ser menos influenciado pelos processos de revelação e copiagem da película. No final da década de 1950, segue o autor, o sistema óptico de área variável com configuração dual bilateral tornouse o padrão da indústria. As duas pistas de som paralelas que caracterizavam esta configuração abrigariam no futuro o sistema estereofônico analógico desenvolvido para o cinema pela Dolby Laboratories.

$\mathrm{Na}$ projeção, os dois sistemas eram compatíveis, permitindo aos exibidores trabalharem com filmes com as duas tecnologias, desde que a sala estivesse adaptada com projetores dotados de fotocélulas e sistema de amplificação eletrônica para a reprodução do som.

${ }^{26}$ A RKO foi a companhia cinematográfica estruturada pela RCA que garantiu a inserção do sistema Photophone na indústria cinematográfica. 
A tecnologia do som óptico trazia algumas vantagens sobre o sistema concorrente. Por carregar o som e a imagem no mesmo suporte, o som óptico estava isento dos problemas de perda de sincronismo encontrado no Vitaphone. A pós-produção do sistema óptico era mais rápida e dependia apenas do processo de revelação e copiagem do material sensível, enquanto que, conforme aponta Eduardo Santos Mendes (2000, p. 11), a pós-produção "do Vitaphone [...] requeria todo longo processo de produção de um disco".

As tomadas sonoras filmadas com som óptico podem ser editadas. Com o sound-onfilm system os planos sonoros são captados com a duração mais adequada (longa ou curta) para a representação da ação com diferentes enquadramentos. Esta característica do sistema possibilita o reestabelecimento do binômio decupagem/montagem, estabelecido pelo cinema clássico silencioso, para a construção da narrativa. Com o sound-on-film system é recuperado o procedimento padrão de filmagem: múltiplos planos com a utilização de uma única câmera. Os planos sonoros podiam ser filmados com a duração e os enquadramentos mais adequados para cada evento e a montagem se encarregaria de criar a unidade espaço-temporal para a ação representada. Nos primeiros tempos do som óptico, a prática da montagem foi comprometida devido ao ruído ${ }^{27}$ produzido pela brusca interrupção da trilha sonora nas emendas dos planos. Este problema foi resolvido pelo criador do Movietone, Theodore Case, ainda no início de 1926, como informa Stephen Handzo (1985, p. 389):

Case solved this drawback as early as 1926 by blooping the splice with a dot of heavy ink (still marketed years later as "Movietone Ink"). Blooping was later performed on the negative with a hole punch or on the positive with a diamond-shaped blooping black celluloid (grifo do autor).

Uma dificuldade irremediável para a montagem das tomadas sonoras com o sistema óptico era o deslocamento físico, de 20 fotogramas, existente entre a posição do registro sonoro e o fotograma correspondente à imagem. Nas câmeras cinematográficas adaptadas para o registro óptico, a válvula de luz estava posicionada 20 fotogramas abaixo da janela de impressão da imagem. Essa disposição deslocada era necessária para atender às necessidades particulares de cada um dos registros. O registro fotográfico necessita de pequenas interrupções do movimento de arraste da película para que a imagem possa ser impressa, enquanto o registro do som deve ser feito em movimento contínuo. Assim, a solução

27 A célula fotoelétrica do projetor "traduzia" os pontos de corte da trilha sonora como uma informação sonora na forma de ruídos audíveis. 
encontrada por Theodore Case foi instalar a válvula de luz, para gravar o som, 20 fotogramas à frente da janela da câmera. Nos projetores, o deslocamento entre a janela de projeção da imagem e a célula fotoelétrica para a leitura do som óptico era o mesmo. Na montagem das cenas com som óptico gravado na câmera, o montador precisava sempre cortar o plano 20 fotogramas à frente do ponto escolhido para não perder o texto correspondente.

Essa limitação para a montagem começou a ser superada na metade de 1929 com o desenvolvimento do sistema double system sound-on-film, em que som e imagem eram registrados sincronicamente em câmeras independentes e podiam ser editados separadamente com a manutenção do sincronismo. Nesse sistema, uma segunda câmera, exclusiva para o registro do som, rodava em sincronia com a câmera de imagem, graças aos motores sincrônicos alimentados a partir de uma mesma fonte de força que garantia que qualquer oscilação na tensão fosse percebida igualmente pelas duas câmeras. Com os suportes independentes, o corte da imagem era realizado sem restrição, e a operação sincrônica dos materiais era garantida pelo emprego dos sincronizadores com rodas dentadas interligadas que permitiam trabalhar com duas ou mais "tiras" de películas simultaneamente. Esse sistema permitiu a restituição do potencial narrativo da montagem com a sofisticação das tarefas de edição. Como destaca Handzo (1985, p. 391):

Instead of working in "projection sync" with the sound in advance of picture, editors worked in "editorial sync" ("bench sync"), and were thus able to match picture and sound splices to the frame. Using the visual image of the clapper and the "spike" made in the optical track by the stick.

Com o arraste do material sendo feito por motor elétrico, os equipamentos de montagem motorizados desenvolvidos pela Moviola Company tornaram o trabalho de edição mais ágil. Os modelos mais sofisticados permitiam a reprodução simultânea da pista de imagem com duas ou três pistas de som. O desenvolvimento lógico a partir da separação dos suportes para a captação do som e da imagem foi a pós-sincronização de sons durante a montagem. Pistas de efeitos sonoros e música passaram a ser acrescidas à pista de som original, captado durante a filmagem, dando início ao procedimento de edição de som que se mantém até os dias de hoje. Essa separação dos suportes permitiu também que filmes pudessem ser dublados para a distribuição internacional. 


\subsection{AS MUDANÇAS DE PROCEDIMENTOS DE REALIZAÇÃO E A INSERÇÃO DO SOM NO ESTILO CLÁSSICO CINEMATOGRÁFICO}

O advento do cinema sonoro não se constituiu como uma ruptura do sistema de produção da indústria cinematográfica norte-americana, ao contrário, como afirma Bordwell (1997a, p. 334, tradução nossa), o som como elemento narrativo e os procedimentos técnicos relacionados com a sua materialização foram inseridos no sistema de produção “já constituído do estilo clássico de Hollywood". Segundo o autor, "esta afirmação pressupõe que em seu conjunto as técnicas relacionadas ao som adaptaram-se às normas de cinematografia muda".

Donald Crafton (1997) reforça esta hipótese ao afirmar que, apesar das significativas mudanças no modo de realizar os filmes, a principal preocupação dos estúdios, na transição para o sonoro, relacionava-se com a manutenção do sistema de produção, financeiramente bem sucedido, estruturado em procedimentos padronizados (atuação, roteiro, fotografia e montagem), que se estabeleceram ao longo do processo de consolidação da indústria cinematográfica. $\mathrm{O}$ autor afirma que a passagem para o sonoro dependia da tripla tarefa dos estúdios

[...] to develop strategies which would maintain the high level of attendance and entice new moviegoers to become regular consumers; to find efficient ways to incorporate the talkies into existing patterns of production with a minimum of economic disruption; and to ascertain and response to audience selectivity (CRAFTON, 1997, p. 225).

A manutenção do interesse e da audiência em relação aos filmes significava incorporar o som no sistema de representação preexistente. O "estilo clássico de Hollywood" é uma denominação que abarca um conjunto de condicionantes e possibilidades de enfoque que vão muito além das pretensões da nossa pesquisa. Tomaremos como base a formulação desenvolvida por Ismail Xavier (1984), no tópico A Representação Naturalista de Hollywood, no capítulo III do livro O Discurso cinematográfico - a opacidade e a transparência, para localizar algumas características deste sistema de representação cinematográfica que permitem entender as necessárias adequações dos procedimentos de filmagem e o seu correlato desenvolvimento tecnológico, os quais visaram a incorporação do som no contexto do estilo clássico de realização. Segundo Xavier (1984, p. 31-32), podemos assumir que o sistema consolidado pela indústria cinematográfica antes da passagem para o sonoro operava 
“com a aplicação sistemática dos princípios da montagem invisível” e construía meticulosamente uma representação do "mundo a ser observada através da 'janela' do cinema", buscando criar no espectador a ilusão de estar diante do mundo representado "como se todos os aparatos de linguagem utilizados constituíssem um dispositivo transparente (o discurso como natureza)". Conforme aponta o autor, para produzir o específico efeito naturalista, este sistema reuniu três elementos básicos:

- a decupagem clássica apta a produzir o ilusionismo e deflagrar o mecanismo de identificação.

- a elaboração de um método de interpretação dos atores dentro de princípios naturalistas, emoldurado por uma preferência pelas filmagens em estúdios, com cenários também construídos de acordo com princípios naturalistas.

- a escolha de estórias pertencentes a gêneros narrativos bastante estratificados em suas convenções de leitura fácil, e de popularidade comprovada [...] (XAVIER, 1984, p. 31).

A proposição do sistema é escamotear os meios de produção da realidade criada pelas imagens e "montar um sistema de representação que procura anular a sua presença como trabalho de representação", abrir uma janela para mundo colocando o espectador na posição privilegiada de quem tem a sensação de participar diretamente daquela realidade. Ismail Xavier (1984, p. 31) ressalta o critério naturalista da representação, referindo-se em particular ao processo de

[...] construção de espaço cujo esforço se dá na direção de uma reprodução fiel das aparências imediatas do mundo físico, e à interpretação dos atores que busca uma reprodução fiel do comportamento humano, através de movimentos e reações "naturais".

Coerente com a proposição do sistema, conforme sintetiza Robert Stan (1981, p. 172), o som deveria intensificar e completar "a impressão de realidade oferecida pela imagem, a fim de reconstituir o mundo auditivo identificável emprestando à imagem a profundidade sonora". A lógica dessa representação pressupõe que a imagem "esteja acompanhada por sons 'naturais' gerados por essa mesma imagem na vida real". Portanto, no contexto de realização do cinema clássico, a captação do som exige a supressão de qualquer fonte sonora que denote o aparato de realização ou que sugira elementos discrepantes ao mundo criado (ou em processo de criação) pelas imagens e sons. Para responder a essa solicitação do sistema de representação, o esforço central dos estúdios, no início da transição para o sonoro, foi a 
criação de dispositivos e procedimentos de filmagem silenciosos que adequassem o set para as novas necessidades do processo de realização. Silenciar o equipamento de luz, a câmera e a construção de estúdios sonoramente isolados eram as principais demandas de realização do cinema clássico sonoro. Conforme aponta Bordwell (1997a, p. 333):

Teniendo en cuenta las necesidades del estilo clásico, el ruido de la cámara se convirtió en un problema engorroso: del mismo modo en que el espectador no debía ver el reflejo de una cámara en un espejo, tampoco debía oír el sonido de la misma.

- Silenciar o set - a substituição do sistema de iluminação.

O processo que culminou com a substituição das luzes de arco voltaico e de vapor de mercúrio pelas lâmpadas incandescentes (conhecido como "Testes Mazda",28, que se realizou no início de 1928) é a exemplificação do esforço coletivo dos estúdios nas mudanças de infraestrutura, adequando-se às novas demandas de realização. Como aponta Crafton (1997, p. 227):

During the transition to sound Hollywood changed to incandescent lights. Traditionally this infrastructural change has been linked to the need for noise reduction on the set because the arcs gave off a "fizz" or "sizzle", and the Cooper-Hewitts' transformers hummed.

Segundo o autor, em junho de 1928, antes da conversão unificada dos estúdios ao novo sistema de iluminação, a Warner Bros., à frente na corrida pela produção dos all talkies, já utilizava exclusivamente a iluminação incandescente, exemplificando a influência da demanda de realização na substituição do aparato técnico para o controle do espaço sonoro do set.

${ }^{28}$ Os "testes Mazda" foram realizados para avaliar a resposta do negativo pancromático sob a iluminação das lâmpadas incandescentes de tungstênio fabricadas pela GE conhecidas pelo nome de Mazda. Segundo Bordwell (1997b) além dos resultados técnicos obtidos, a importância do processo está no fato de ser o primeiro esforço coletivo dos estúdios pela busca de soluções padronizadas para o processo de realização. Bordwell aponta que a redução dos custos de produção, aliado ao menor nível de ruído das luzes incandescentes, determinaram a substituição dos sistemas de iluminação anteriores. Para maiores detalhes, ver Bordwell (1997b). 
- Silenciar o set - redução do ruído da câmera.

Considerada padrão do período que antecedeu a transição para o sonoro, a câmera fabricada pela Bell and Howell Company, com corpo e chassi metálico e valorizada pelos operadores pela perfeita estabilidade de imagem, era totalmente inadequada à filmagem com som sincrônico devido ao excessivo ruído produzido. Antes da conversão global para o sonoro e da busca de soluções coletivas organizada pela AMPAS, os estúdios buscaram soluções individuais para silenciar a câmera no set. Segundo Crafton (1997), a Warner passou a empregar câmeras da Mitchell Company com mecanismo adaptado, as quais produziam menos ruído. No entanto, para a completa extinção do ruído produzido pelo equipamento, a Warner optou por confinar a câmera em cabines à prova de som (soundproof booth). As grandes caixas vedadas ao som que continham a câmera e operador em seu interior ficaram conhecidas como sweat booth ou icebox. Elas eram desajeitadas e implicavam num set pouco ágil, com menor mobilidade da câmera e da equipe de filmagem. No entanto, questionando a lenda sobre a imobilidade do cinema sonoro da transição ${ }^{29}$, as cabines não eram totalmente estáticas e, no seu interior, as câmeras podiam realizar pequenas correções, acompanhando a ação dos personagens e reenquadrando a cena. Como afirma Crafton (1997, p. 230):

Mounted on wheels, it could be pushed around the soundstage with its cables dragging. The opening (covered with optically ground glass to reduce refraction) was wide enough to facilitate short pans and reframing movements. It was also possible to use the booth outdoors.

No interior das cabines, um ou dois operadores podiam ouvir o som da cena ou comunicavam-se com o engenheiro de som através de intercomunicadores. A maior distância das câmeras em relação à cena era compensada com a utilização de lentes com maior distância focal. A Foto 3 revela o interior de uma cabine de câmera à prova de som, à frente do operador pode-se ver a abertura de vidro para o enquadramento da cena.

\footnotetext{
${ }^{29}$ Bordwell (1997, p. 338), assim como Crafton (1997), contestam a ideia de que o cinema sonoro da transição era estático e carecia de montagem. Bordwell afirma que, "havia abundante montagem nos primeiros filmes falados, com muitos planos por cena", tomando como exemplo o primeiro all talkies produzido (Lights of New York, de 1928) para comprovar quantitativamente este questionamento. Bordwell revela que o primeiro longa-metragem totalmente falado contém em média 30 planos por cena e que a duração média dos planos é de 9 segundos, ficando apenas com 3 segundos a mais do que a média de duração dos planos dos filmes produzidos na década anterior que era de 6 segundos.
} 


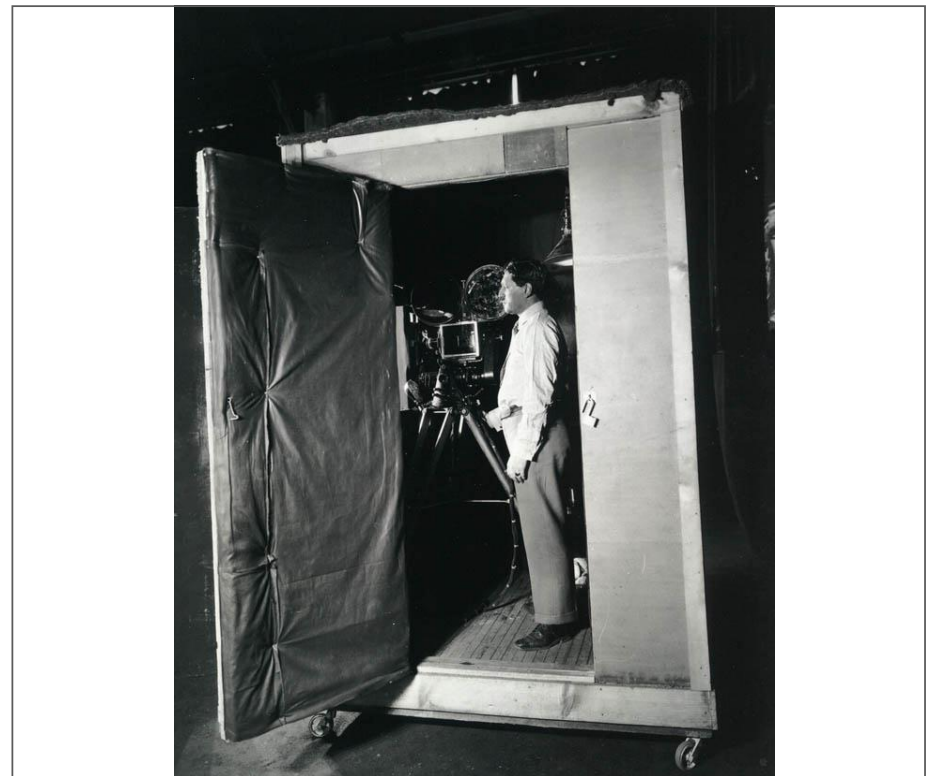

Foto 3 - A soundproof booth construída sobre rodas com revestimento interno para absorção do som.

Por sua vez, a Fox adotou uma solução mais flexível na redução do ruído das câmeras. Na produção inicial dos cines-jornais da Fox foram utilizadas mantas de material absorvente, denominadas "horse blankets", que cobriam a câmera no momento da tomada. Em 1930, o esforço coletivo dos produtores, técnicos e fabricantes, coordenados pelo ProducersTechnicians Committee da AMPAS, frutificou no desenvolvimento da câmera Mitchell NC, chamada "News Rell Camera", e de uma couraça antirruído constituída de fibra, também fabricada pela Mitchell Camera Corporation. Essa couraça (blimp) ajustava-se perfeitamente ao corpo da câmera, permitindo que o operador tivesse acesso ao comando de foco e ao visor e tornando-se o sistema padrão dos estúdios até o advento das câmeras "autoblimpadas", em 1934. Para viabilizar a operação das pesadas câmeras, driblando o sobrepeso do sistema, foram desenvolvidos diferentes dispositivos de suporte e transporte, tais como: dollies, tripé giratório com rodas, pequenas gruas. Bordwell (1997a, p. 341, tradução nossa) afirma que em 1933 as limitações técnicas trazidas pela necessidade de silenciar as câmeras já haviam sido superadas e que os dispositivos desenvolvidos permitiam "que a equipe preparasse um plano atrás do outro com a mesma facilidade da produção do filme mudo”. Segundo o autor, os dispositivos técnicos desenvolvidos para responder às demandas trazidas pelo som acabaram por influenciar no estilo visual das películas do período de transição. Os novos suportes das câmeras propiciaram meios para a realização de "uma quantidade surpreendente de 
movimentos de câmera" que se incorporariam definitivamente à estética do cinema clássico (BORDWELL, 1997a, p. 341, tradução nossa).

- O sistema de múltiplas câmeras - preservando a montagem.

A mudança de procedimento de realização que mais explicitamente revela a opção pela manutenção das premissas do cinema clássico na transição para o sonoro foi o emprego de múltiplas câmeras nas filmagens com registro de som sincrônico usando o Vitaphone. Como vimos anteriormente, a gravação em disco não permitia a interrupção da ação para a mudança da posição e do enquadramento da câmera. Como as técnicas de pós-sincronização ainda não haviam sido desenvolvidas, a forma encontrada para evitar planos longos e estáticos foi o emprego de múltiplas câmeras para a filmagem. Várias câmeras com diferentes enquadramentos registravam simultaneamente a ação que era executada de forma contínua. Uma opção complexa, que obrigava a iluminação da cena por diferentes ângulos, obtendo um resultado fotográfico pouco satisfatório. Também se mostrava dispendiosa com desperdício de material sensível, pois a captação sobreposta da cena gerava material duplicado, o qual era jogado fora, mas mesmo assim se impôs pela necessidade da manutenção do controle da narrativa por meio do binômio decupagem/montagem ${ }^{30}$. Como aponta Bordwell (1997a, p. 339) o cinema clássico de Hollywood havia estabelecido um vínculo estreito entre a narração e a montagem, "o desenvolvimento psicológico do drama" dependia da articulação fluida dos planos realizada pela montagem. Para o autor:

Dada la importancia capital del montaje en el paradigma clásico, la llegada del sonido supuso una amenaza. Por razones tanto económicas como de estilo, se hubo de preservar la opción del montaje. La tarea pasó a ser la de insertar sonido en el modelo cinematográfico ya existente. El resultado inmediato fue la estandarización del rodaje con múltiples cámaras (BORDWELL, 1997a, p. 339).

\footnotetext{
${ }^{30} \mathrm{Na}$ acepção empregada por Ismail Xavier, que entende que montagem e decupagem são logicamente equivalentes, pois uma pressupõe a outra e o "uso dos dois termos deve-se a uma ordem cronológica encontrada na prática, onde decupagem identifica-se com a fase de confecção do roteiro do filme e montagem, em sentido estrito, é identificada com as operações materiais de organização, corte e colagem dos fragmentos filmados" (XAVIER, 1984, p. 28).
} 
A filmagem com múltiplas câmeras foi a solução para garantir a manutenção da fluidez narrativa alcançada no período mudo por meio da decupagem/montagem que, se não foram totalmente recuperadas em função das características técnicas do sistema de registro sonoro e das dificuldades decorrentes de posicionamento das cabines de câmera em relação à ação, ao menos mantinham a possibilidade de representar a ação em vários planos e ângulos que mantinham os alicerces do padrão narrativo do sistema clássico. Filmar com "múltiplas câmeras foi uma prática dominante em Hollywood entre 1929 e 1931" até o abandono do sistema Vitaphone para a realização do registro sonoro. $\mathrm{O}$ desenvolvimento do registro óptico em suporte separado da imagem foi o encaminhamento técnico necessário para restaurar o potencial da montagem, permitindo a recuperação do controle sobre a construção do tempo e do espaço narrativo. Como sintetiza Bordwell (1997a, p. 336):

La victoria del sistema sonoro óptico de Movietone sobre el sistema de disco de Warner se debió, al menos en parte, al hecho de que poniendo sonido óptico sobre a película se podía realizar el montaje con a misma libertad que la banda visual. En 1930, Moviola produjo el primero de los numerosos modelos para sonido y en aquel mismo año se estaban montando diversas tomas sonoras para conseguir las mejores bandas de sonido.

Os procedimentos técnicos desenvolvidos para a inserção do som no contexto do sistema clássico deixaram heranças impressas no estilo dos filmes e nas práticas do set. Isso se exemplifica no caso do emprego de várias câmeras, pois a partir de 1932, após o abandono do procedimento sistemático da filmagem com múltiplas câmeras, instaurou-se como técnica padronizada de filmagem, a realização do plano máster (filmar a ação do começo até o final com um enquadramento geral) para depois realizar a decupagem da cena, com decomposição da ação em vários planos. Este procedimento é uma prática herdada do sistema de filmagem com multicâmeras, em que sempre existia uma câmera em plano geral, rodando ininterruptamente durante toda a ação. Conforme Bordwell (1997a, p. 343):

En el período mudo, era habitual filmar cada acción en un plano sin superposiciones considerables de acción entre unos planos y otros. El rodaje con múltiples cámaras, sin embargo, acostumbró a operadores y directores a llevar un registro de toda la acción en un plano general.

$[\ldots]$

Aunque el rodaje con múltiples cámaras dejó de utilizarse, el concepto de «plano máster» se mantuvo. Después de 1932, filmar a toda la escena de frente y en plano general se convirtió en una práctica estándar. Después las acciones clave se repetirían y se volverían a rodar a menor distancia. Este 
procedimiento permite, evidentemente, un mayor control en el montaje: se tiene la acción cubierta en todo momento y siempre hay un plano al que se puede recurrir.

Os novos procedimentos de filmagem desenvolvidos para incorporar o som na estrutura de produção preexistente, preservando o alicerce narrativo do sistema, reorganizaram o método de trabalho dos estúdios e influenciaram mudanças no estilo clássico cinematográfico.

\subsection{A TÉCNICA E OS PROCEDIMENTOS DE CAPTAÇÃO DE SOM NOS PRIMEIROS TEMPOS}

Com a possibilidade técnica de gravação e reprodução de som sincrônico com a imagem, o sistema de representação do cinema de estilo clássico se potencializou. Conforme afirma Ismail Xavier (1984, p. 27), o princípio do som sincronizado com a imagem 31 "era necessário para o aperfeiçoamento do método clássico", pois a possibilidade de "tornar audível o que já está sendo visto é uma forma de torná-lo mais convincente". Apesar das reações contrárias e das severas críticas ao uso do som sincrônico com a possibilidade da destruição da "cultura da montagem", como afirmava o manifesto de 1928 (Sobre o futuro do

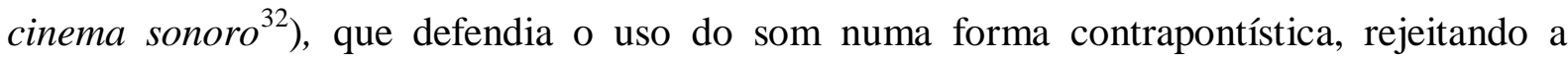
redundância com as imagens, o cinema industrial americano, percebido na prática da produção, reiterou o uso do som sincrônico, agregando recursos ao esquema de representação "fiel das aparências imediatas do mundo físico" a serviço da intensificação da impressão de realidade. Xavier (1984, p. 27) ressalta que, além da possibilidade de construção pormenorizada do ruído ambiente ${ }^{33}$, a possibilidade de sincronização da voz por meio da "presença efetiva da palavra, vem conferir mais espessura e corporeidade à imagem, aumentando o seu poder de ilusão".

\footnotetext{
${ }^{31}$ Conforme definição do autor, é o princípio que "estabelece a colocação das palavras e ruídos nos exatos momentos em que vemos funcionar a fonte emissora, de modo a produzir uma correspondência aceita como natural entre a imagem e o som" (XAVIER, 1984, p. 27).

32 A versão em português da crítica ao som sincrônico, assinado por Eisenstein, Pudovkin e Alexandrov, pode ser encontrada em Sergei Eisenstein, A forma do filme. Rio de Janeiro: Jorge Zahar, 1990. p. 217-219. A versão em Inglês em WEIS, Elisabeth, BELTON, John (Org.). Film Sound: theory and practice. New York: Columbia University Press, 1985, p. 833-85.

${ }^{33}$ Assumindo os avanços tecnológicos e os procedimentos que permitiram a montagem e a pósprodução do som.
} 
De acordo com Bordwell (1997a, p. 336, tradução nossa), coerente com as necessidades do modelo de narração do cinema clássico, em que “o diálogo constitui o principal veículo da ação narrativa e deve estar tão personalizado como o rosto, o corpo e o espaço", a voz passa a desempenhar papel fundamental na estrutura da narrativa, sendo assumida como o elemento de maior importância na trilha sonora, possuindo a mesma "relevância que a figura humana desempenha na imagem".

A partir de aspectos sensoriais, Michel Chion (2004, p. 17) explica a importância e a centralidade da voz na trilha sonora cinematográfica, característica que denominou de "vococentrismo cinematográfico". O autor afirma que "a presença de uma voz humana hierarquiza a percepção ao seu redor" e detalha que este mecanismo se processa em qualquer espaço sonoro que comporte uma voz humana. Segundo ele, nesta situação:

[...] el oído inevitablemente le presta atención, aislándola y estructurando en torno a ella la percepción del todo: trata de pelar el sonido para extraer el significado del mismo, intenta siempre localizar y si es posible, identificar la voz (CHION, 2004, p.18).

O argumento de Chion (2004) invoca a imantação sensorial exercida pela voz humana, referendando a opção do cinema clássico pela utilização da voz no diálogo como principal veículo da ação narrativa. Segundo o autor, é inerente ao mecanismo sensorial o desejo de se compreender o que se diz. Para o autor, refletindo esta condição, os procedimentos desenvolvidos pelo cinema clássico se orientam no sentido de intensificar a voz e o texto por ela sustentado, entregando-os em posição de destaque ao espectador. Baseado no potencial sensório, o autor argumenta que os procedimentos de captação buscam o controle artificial do nível e da presença da voz em relação às demais fontes sonoras, compensando a ausência de referências que permitiriam ao espectador, numa escuta direta, isolar a voz do diálogo dos demais ruídos ao redor. A captação de som que se desenvolve poderia ser entendida, na verdade, como os procedimentos de captação da voz, com o trabalho sistemático de controle e supressão dos outros elementos sonoros, revelando como "as normas técnicas e estéticas do cinema clássico se concebem implicitamente para colocar em destaque a voz e a inteligibilidade do diálogo" (CHION, 2004, p. 18).

Conforme Rick Altman (1992), em seu texto Sound Space, o que se verifica no estabelecimento do padrão estético do som sincrônico durante os primeiros anos do cinema sonoro é o embate entre as proposições professadas pelos engenheiros de som - responsáveis 
pelo desenvolvimento da tecnologia e pela implantação dos procedimentos de captação - e as práticas de trabalho que concretizaram a sonoridade do novo meio. Nos primeiros anos de implantação do sonoro, a proposição hegemônica, divulgada por meio de textos publicados nos boletins das entidades técnicas, advogava a necessidade da manutenção da "natural proporcionalidade entre imagem e som", baseada numa suposta percepção natural que "existe entre a imagem de alguém falando e a voz associada a ela". Essa proporcionalidade se materializaria por meio da diferença de presença e intensidade dos sons que acompanhavam as imagens, significando que a voz ouvida num plano próximo deveria soar mais intensa e mais presente do que a aquela ouvida em um plano geral. A proposição da adequação de proporcionalidade entre imagem e som, defendida pelos mais influentes engenheiros de som do período ${ }^{34}$, conforme Altman (1992, p. 49, tradução nossa), era reforçada por J. P. Maxfield, que proclamava que a "escala do som deveria sempre adequar-se à escala da imagem", justificado pela experiência da vida real.

Supporting his own argument that sound scale must always match image scale, Maxfield insisted repeatedly that the eyes and ears of a person viewing a real scene in real life must maintain "a fixed relationship" to one another (ALTMAN, 1992, p. 49).

Nessa proposta, a trilha sonora deveria preservar a percepção auditiva natural do ambiente representado pela imagem. Portanto, a perspectiva sonora era condicionada pela perspectiva revelada pela imagem. Segundo Altman (1992), no início da década de 1930, Maxfield já havia demonstrado a importância da reverberação acústica na representação da perspectiva sonora e sua influência na percepção global do fenômeno sonoro por parte dos espectadores, deixando claro que "[...] volume alone is insufficient marker of distance, Maxfield had earlier revealed the importance of reverberation (or more accurately, the ratio of reflected sound to direct sound) for determining of sound scale" (ALTMAN, 1992, p. 48).

A captação do som no set com a adequação entre as escalas de som e de imagem era normatizada por procedimentos técnicos definidos pelo próprio Maxfield, que propunha o uso de um único microfone, posicionado próximo à câmera e orientado na linha de visão da

\footnotetext{
${ }^{34}$ Entre os propositores da estética da manutenção da proporção entre som e imagem, Altman destaca Carl Dreher (engenheiro de som chefe do estúdio RKO), John L. Cass (técnico de som da RCA) e fundamentalmente, J. P. Maxfield (engenheiro chefe da ERPI) responsável, ainda em 1931, pela publicação das normas que determinam a distância para o posicionamento do microfone em ralação a fonte sonora, considerando a distância da câmera em relação ao objeto filmado e a distância focal da lente empregada, para a adequada relação de escala entre som imagem.
} 
câmera, de modo a, automaticamente, captar o som na forma correta aos pressupostos da proporcionalidade. Esse posicionamento do microfone permitiria a captação do som com variação de presença resultante da aproximação ou do afastamento dos atores em relação à câmera. Conforme Altman (1992, p. 50):

Characters approaching the camera automatically approach the microphone as well, thus matching closer image scale to closer sound scale; conversely, the character who speaks from the background demonstrates distant characteristics in sound and image alike.

Enquanto o uso de um único microfone fixo e "corretamente" posicionado garante a adequação entre as escalas do som e da imagem no interior de uma tomada, um conjunto de orientações é necessário para garantir a correta proporcionalidade entre som e imagem numa sucessão de planos com diferentes enquadramentos. De acordo com Altman (1992, p. 52), em 1931, Maxfield publicou uma sistematização de normas que determinam a distância para o posicionamento do microfone em relação à fonte sonora, levando em consideração a distância focal da lente empregada na tomada e a distância do ator em relação à câmera, como pode ser visto no Gráfico 1. O gráfico relaciona a distância focal da lente no eixo das abscissas em função da distância do microfone à fonte sonora (a distância do microfone é dada em termos da porcentagem da distância da câmera) no eixo das ordenadas. Segundo Maxfield ${ }^{35}$ (1931 apud ALTMAN, 1992, p. 52), os dados utilizados para a construção do gráfico foram originados da experiência prática de captação de som durante os primeiros anos do cinema sonoro.

${ }^{35}$ MAXFIELD. J. P. Some physical factors affecting the illusion in sound motion pictures. JASA, v. 3, n. 1 , p. 69-80, jul. 1931. 


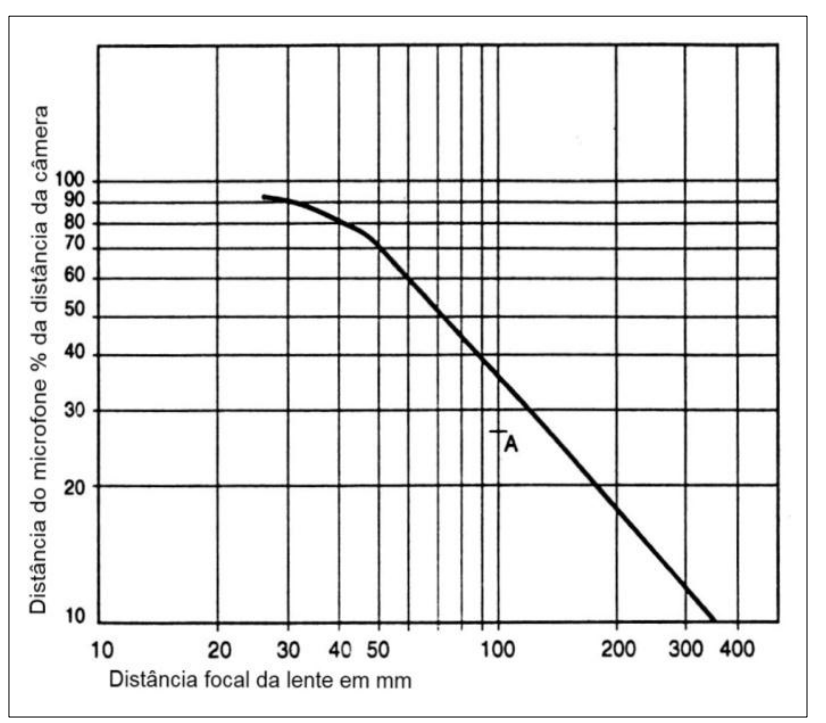

Gráfico 1 - Distância do microfone em função da distância focal da lente (adaptado a partir de ALTMAN, 1992, p. 52).

Os microfones inicialmente empregados na captação de som no início do cinema falado, no final dos anos 1920, produzidos pela RCA ou pela Wastern Electric, derivavam de equipamentos empregados em telefonia e radiodifusão. Nessas aplicações, a característica de captação omnidirecional desses equipamentos era compensada por meio do posicionamento da fonte sonora próxima ao microfone, gerando um sinal intenso que mascarava a reverberação e outras fontes de menor intensidade (HANDZO, 1985, p. 396-397). No entanto, na realização cinematográfica clássica, que pressupõe a ocultação dos dispositivos de realização, o posicionamento e a proximidade do microfone com a fonte sonora era determinada pela imagem: o microfone não podia ser visto em quadro. Para garantir a captação de vozes com presença e inteligibilidade, driblando a falta de direcionalidade dos microfones e a limitação determinada pela imagem, uma prática de filmagem recorrente era o posicionamento dos microfones próximos aos atores escondidos no interior do cenário. Este procedimento foi denominado por Carl Dreher como "prop ${ }^{36}$ pick-ups", microfones camuflados por "objetos de cena posicionados suficientemente próximos aos atores para garantir a captação das falas com qualidade aceitável” (ALTMAN, 1992, p. 53, tradução nossa). Exemplificando esta prática, Stephen Handzo (1985, p. 397) relata o procedimento

\footnotetext{
${ }^{36}$ Props ou properties são designações utilizadas no cinema norte-americano para denominar os pequenos objetos de cena utilizados para decorar o cenário das realizações ficcionais.
} 
adotado para a captação do som numa cena do longa-metragem Luzes de Nova Iorque (The Lights of New York $)^{37}$ :

In the earliest all-talking feature, The Lights of New York, the microphone actually is the mouthpiece of candlestick phone on the desk of a gangster barking orders to his henchmen ("Take him for a ride"). It was quite common in the earliest talkies for the mike to be concealed in flower-pots, fruits bowls, overhead light fixtures, or anything that would bring it close to the actors.

Buscando garantir a inteligibilidade das falas e contrariando a proposição da adequação de escalas, Altman (1992) afirma que durante os primeiros anos, em cenas captadas em plano único, empregando-se múltiplas câmeras, foi largamente utilizada a captação de som com o emprego de múltiplos microfones, os quais eram afixados fora de quadro, suspensos por corda, ligados a uma mesa de controle de volume operada pelo técnico de som. Controlando o volume dos microfones, o técnico de som acompanhava a movimentação do ator em cena e mixava os vários canais, abrindo o ganho do microfone que estivesse mais próximo do ator e garantindo a captação da voz com a máxima presença possível. Os defensores da "adequação de escalas" criticavam esse procedimento, alegando que a representação sonora obtida com o emprego de múltiplos microfones assemelhava-se a uma aberração auditiva. Segundo eles, não existia um ponto definido de audição, mas ao contrário, "seria o som ouvido por alguém dotado de cinco ou seis longas orelhas" como afirma John L. Cass, técnico de som da RCA, opondo-se ao emprego desta estratégia (ALTMAN, 1992, p. 49).

Ainda em 1930, na tentativa de potencializar a presença da voz e excluir ruídos indesejados na captação, Carl Dreher, da RKO, desenvolveu um sistema que alterava o padrão de captação dos primeiros microfones, tornando-os direcionais. O sistema foi denominado "concentrator microphone" ou "beam microphone" numa analogia entre o facho luminoso de um refletor e o eixo preferencial de captação criado pelo dispositivo de Dreher. Segundo Donald Crafton (1997, p. 238), era um sistema com captação eficiente, porém extremamente desajeitado, constituído por "um microfone posicionado no foco de um refletor parabólico de

${ }^{37}$ LUZES de Nova Iorque. Direção de Bryan Foy. 1928. 1 filme (57 min): son., P\&B,; 35 mm. Considerado o primeiro longa-metragem totalmente falado. Lançado pela Warner Bros. em 28 de julho de 1928. 
aproximadamente noventa centímetros de diâmetro que concentrava sobre o microfone as ondas sonoras de uma fonte posicionada à frente do parabólico".

No início de 1931, a RCA lançou os primeiros microfones direcionais que tornaram o parabólico obsoleto. Esses dispositivos eram conhecidos como microfones de fita (ribbon microphones) e apresentavam padrão de captação bidirecional. A amplificação eletrônica do sinal era realizada por um pesado pré-amplificador incorporado à estrutura do microfone. De acordo com Crafton (1997, p. 238), a concorrente, Western Electric, introduziu um microfone direcional eletrodinâmico que diferia dos anteriores por ser menor e mais leve, pois a amplificação do sinal do microfone era feita por um circuito eletrônico que não fazia parte do corpo do microfone e podia estar "até sessenta metros de distância". A redução do tamanho e do peso possibilitou a movimentação dos microfones por meio da utilização de suportes móveis (booms) que acompanhavam os atores durante a cena.

Donald Crafton (1997, p. 241-242) afirma que o emprego dos booms ocorreu de forma "espontânea" no seio da indústria cinematográfica quando os microfones se tornaram mais leves. Conforme relata o autor, o desenvolvimento de protótipos que permitiam a movimentação dos microfones aconteceu em diferentes estúdios, o que reforça a ideia de uma busca para solucionar uma demanda comum a toda indústria cinematográfica: tornar a voz presente e inteligível. O relato de E. C. Richardson, da Mole Richardson Company, (apud CRAFTON, 1997, p. 242) declara algumas das tentativas de tornar os microfones móveis e descreve o protótipo desenvolvido pela MGM, que orientou a construção do dispositivo que se tornaria o equipamento padrão utilizado pelos estúdios, fabricado pela Mole Richardson Company, a partir de 1930.

As the sets became larger it became necessary to use a plurality of microphones and to fade from one circuit to another as the actors moved about. This operation of fading from one microphone to another contributed to errors in recording which while excusable a year ago would be highly criticized today.

To obviate the use of plural microphones several devices were used. For instance, a microphone was sometimes suspended from the ceiling by means of a cord and moved about with a long pole, an operator quite obviously called "fishing". Some studios had their prop departments construct supporting arms or booms which would facilitate the quick placement of microphone. Most of these pieces of equipment were hurriedly made and crudely constructed and none too satisfactory in their operation.

[MGM is using a boom which] consists of a substantial base supporting a vertical column which in turn supports a lever arm having an adjustable portion which can be extended or retracted at will by operating a cable drum 
by means of a crank from the floor. The under-balanced portion of the boom and the weight of the microphone are counterbalanced by a fixed counterweight and the boom is operated upon its vertical and transverse axis by an operating lever (RICHARDSON ${ }^{38}, 1930$ apud CRAFTON, 1997, p. 242).

O boom permitiu a movimentação silenciosa e precisa do microfone, o qual seguia o percurso dos atores durante a cena com a realização de delicadas correções que asseguravam o posicionamento do microfone na menor distância possível em relação à fonte sonora. A utilização do boom tornava relativamente fácil a permanência do microfone fora do campo de visão da câmera, que trabalhava acima da linha superior do quadro e conservava praticamente a mesma distância em relação à fonte sonora durante toda a tomada. O boom era dotado de base com rodas ou suspenso por tripé com rodas, as quais agilizavam o posicionamento do microfone no set, como pode ser visto na Foto 4.

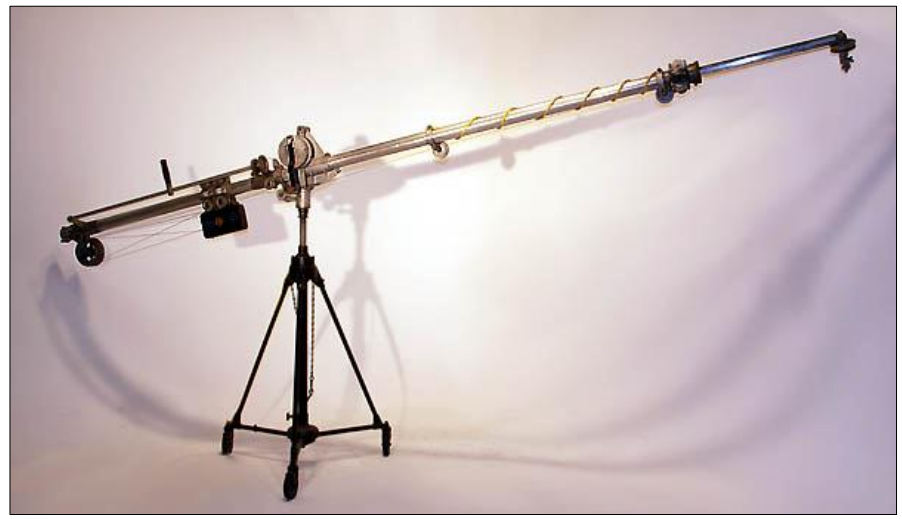

Foto 4 - Boom da Mole-Richardson - modelo 103B sustentado por tripé com rodas.

O emprego dos microfones direcionais móveis, operados pelo boom, modificou as características do registro do som sincrônico. Com o boom, o microfone era colocado o mais próximo possível dos atores e mantinha a mesma distância durante toda a tomada e a voz era captada com destaque e presença contínua. As características da tomada de som realizada com o emprego do boom diferenciavam-se significativamente daquela realizada com um único microfone imóvel. Como aponta Altman (1992, p. 53):

With a single microphone immobile mike, such as that championed by Maxfield, the spatial characteristics of the pro-filmic scene were already inscribed on the sound track. A character receding or turning away from the

${ }^{38}$ RICHARDSON, E. C. Film Daily. n. 7, may 1930, p. 6. 
mike was recorded with a higher ratio of reflected to direct sound; similarly, the size of the room had its effect on volume, reverberation, and frequency characteristics. With the new system, however, the microphone is perpetually kept within approximately the same distance of the speaker, thus cancelling out nearly all factors which the earlier system retained.

O emprego do direcional móvel reduz os indesejados ruídos do ambiente, assim como minimizam a presença dos ruídos da própria cena, resultando num plano sonoro com a qualidade característica de um permanente close-up. De acordo com Altman (1992, p. 53, tradução nossa), associada às aquisições tecnológicas surgidas ao longo da década de 1930 as quais permitiriam a pós-sincronização e mixagem de sons, utilizando processadores para a voz, equalizadores e reverberadores - essa nova estratégia de captação trazia "os benefícios econômicos e o indispensável controle relacionado ao sistema que possibilitava a construção da trilha sonora em vez de uma captação sincrônica já construída com todos os sons". O autor destaca as características do registro sincrônico que se tornariam os parâmetros de qualidade do som direto, definidos a partir do código de representação criado pelo cinema clássico durante este período. Segundo o autor:

Parallel to many image-treatment processes which permitted the Hollywood of the thirties to exercise control over the image while reducing the cost of its production, sound construction processes serve to enhance the ability of the boomed mike to provide a clean, clear, continuous sound record, oblivious to image scale but attuned to dialogue intelligibility, story continuity and freedom of action (ALTMAN, 1992, p. 53-54).

Altman (1992, p. 54) aponta que apesar da força das propostas para a constituição de uma representação sonora cinematográfica, baseada na experiência cotidiana da vida real, respeitando a adequação entre as escalas do som e da imagem, o modelo de representação que se tornou hegemônico, ao longo da década de 1930, buscava a inteligibilidade da voz. Segundo Altman (1992, p. 54), os procedimentos de captação desenvolvidos pelos técnicos de som

[...] having internalized a new standard, the technicians no longer sought to match sound scale to image scale through "correct" microphone placement, but instead sought to produce a continuous sound track of nearly level volume and unbroken close-up characteristics. Throughout the thirties it was for clarity of their sound tracks that sound technicians had been praised and rewarded, rather than for their spatial realism. 
Altman (1992, p. 59, tradução nossa) comenta três aspectos para justificar a predominância da inteligibilidade da fala sobre a adequação entre as escalas do som e da imagem. $\mathrm{O}$ primeiro aspecto relaciona-se à preponderância narrativa no cinema clássico. $\mathrm{O}$ autor afirma que a prioridade pela inteligibilidade da palavra com o sacrifício da fidelidade acústica do espaço fílmico representado na imagem sugere "que o referente do som do filme de Hollywood não é a cena em si, mas a narrativa construída que se desenvolve por trás da cena, é a narrativa que autoriza e produz a cena que nada mais é do que um significante da própria narrativa".

O segundo aspecto determinante na preponderância da inteligibilidade da fala relaciona-se ao código de realidade adotado para a representação do cinema clássico. De acordo com Altman (1992, p. 59, tradução nossa), a defesa da fidelidade sonora com a preservação da adequação entre as escalas do som e da imagem toma como referência um "código de realidade derivado do cotidiano", em que pessoas posicionadas a longa distância têm pequena intensidade de voz, em oposição às pessoas posicionadas proximamente, as quais apresentam voz mais intensa. Altman afirma que, a opção pela inteligibilidade da fala toma como referência o código de realidade representacional de outro sistema narrativo. Em suas palavras:

[...] the medium that taught the audiences of the twenties and thirties to expect visual narrative to provide intelligible dialogue. I speak of course of the theater, that old enemy of "pure cinema," back to haunt the faithful once again. For if sound cinema continued to practice intelligibility in spite of repeated appeals for acoustic fidelity, it was because cinema continued to find in the theater a long-consecrated code of reality applicable to audiovisual narratives (ALTMAN, 1992, p. 59).

O terceiro aspecto comentado por Altman (1992, p. 61) está relacionado com a função unificadora desempenhada pela trilha sonora na articulação estabelecida entre os sons e as imagens na montagem de estilo clássico. $\mathrm{O}$ autor salienta que o volume uniforme do registro sonoro contribui para a invisibilidade da montagem, potencializando o caráter ilusionista da representação cinematográfica clássica. Considerando ainda, como afirma Bordwell (1997a, p. 336), que até o final dos anos trinta a pós-sincronização das vozes por meio da dublagem oferecia escassa fidelidade, a maior parte dos diálogos era registrada através da captação sincrônica com as imagens e, portanto, o registro sonoro com volume uniforme era uma 
característica necessária que objetivava a norma geral proposta pelo sistema de representação do cinema clássico. Como afirma Rick Altman (1992, p. 61):

The construction of a uniform-level sound track, eschewing any attempt at matching sound scale to image scale, thus takes its place alongside the thirties' numerous invisible image-editing devices within the overall strategy of hiding the apparatus itself, thus separating the spectator from the reality of the representational situation, thereby making that spectator more available for reaction to the subject-placement cues provided by the fiction and its vehicle.

Os parâmetros que caracterizam a qualidade técnica do som direto na atualidade decorrem do código de representação estabelecido pelo cinema clássico constituído ao longo da década de 1930, o qual determina a busca por um registro sonoro limpo, claro e homogêneo, com a atenção voltada à perfeita compreensão da palavra falada. Esses parâmetros estão internalizados na prática profissional contemporânea como características técnicas inerentes ao som direto.

\subsection{NOVA TECNOLOGIA E NOVOS PROCEDIMENTOS NA CAPTAÇÃO DO SOM DIRETO}

A tecnologia magnética para gravação e reprodução sonora é introduzida na indústria cinematográfica após 1947. Por abranger um espectro de frequências mais amplo e por suportar uma variação dinâmica maior, quando comparada ao sistema óptico, a tecnologia magnética permite uma gravação/reprodução com maior fidelidade. A melhor qualidade na resposta sonora do sistema magnético determinou que os estúdios realizassem a conversão para a nova tecnologia.

Segundo Handzo (1985, p. 391), um ano após a conversão completa da Paramount, em 1950, a maioria dos grandes estúdios norte-americanos seguiu o mesmo caminho e passaram a utilizar a tecnologia magnética no processo de criação da trilha sonora cinematográfica: gravação, edição e mixagem. A gravação magnética apresentava claras vantagens sobre a antecessora óptica, além da maior fidelidade sonora. O suporte magnético apresentava menor ruído de fundo, assim a geração de cópias durante a pós-produção trazia menor deterioração do sinal gravado. Outra vantagem era a possibilidade do som ser ouvido imediatamente após a 
gravação, dispensando a necessidade de revelação e cópia do material, como acontecia no sistema óptico. O suporte físico empregado para o registro sonoro possibilitava a reutilização após ser desgravado. Como no processo de constituição da trilha sonora, desde a captação do som direto até a cópia de exibição, eram realizadas várias gerações do sinal de áudio gravado. As vantagens trazidas pela gravação magnética eram insuperáveis.

Para o emprego da tecnologia de registro sonoro magnético na realização cinematográfica foi desenvolvido como suporte de gravação à fita magnética perfurada (ver Foto 5). O "magnético perfurado" (magnetic sprocketed film) é uma fita constituída por uma base de celuloide coberta com emulsão ferromagnética, com o mesmo padrão de perfurações da película de imagem; as perfurações garantiam a sincronização mecânica entre os suportes do som e da imagem. Durante a captação, o controle da velocidade da câmera e do gravador de som era realizado por meio da utilização de motores sincrônicos alimentados a partir de uma mesma fonte de força, mesmo princípio utilizado anteriormente no double system soundon-film. A utilização do termo MOS, um acrônimo de motor only sinch, para denominar as cenas rodadas sem a captação de som, se origina do princípio de funcionamento desse sistema, que precisava do motor do gravador de som para estabilizar a velocidade da câmera a 24 quadros por segundo. Por isso, mesmo em cenas sem a captação de som, o motor do gravador precisava estar em funcionamento para garantir a velocidade estável da câmera. Nesta situação, o gravador de som "rodava" sem material sensível, daí o nome "motor apenas para sincronismo".

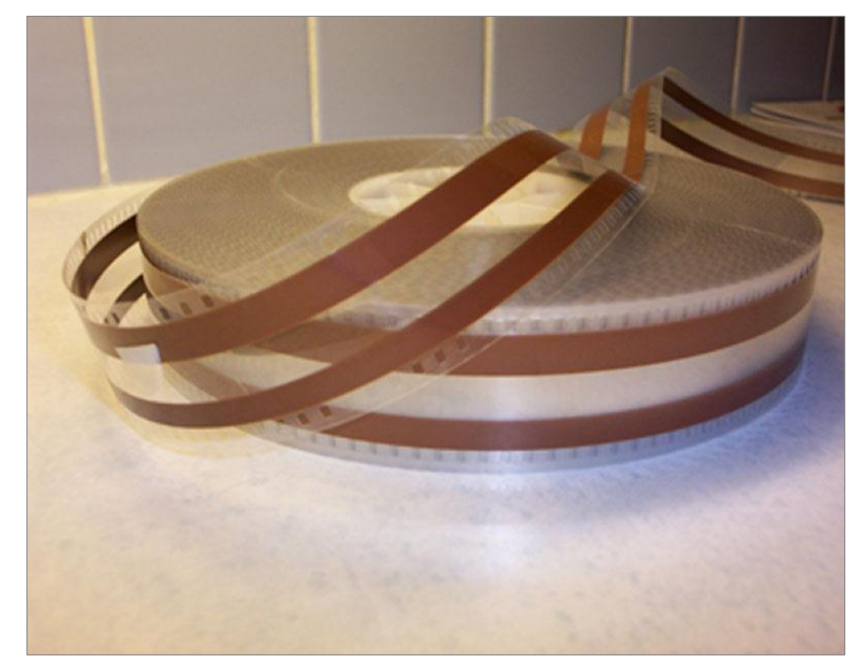

Foto 5 - Rolo de "magnético perfurado" com bitola $35 \mathrm{~mm}$. 
Para os procedimentos de edição, as mesas de montagem foram dotadas com "cabeças de leitura" magnéticas para a reprodução do som, utilizando a fita magnética perfurada. A melhor qualidade do sinal sonoro propiciada pela tecnologia magnética estimulou o uso do novo suporte na exibição. A tecnologia magnética do som permitiu o desenvolvimento de sistemas de projeção multicanais e a tentativa de implantação do uso da estereofonia na exibição cinematográfica por meio de complexos sistemas como o Cinerama e Todd-AO. Conforme dispõe Eduardo Mendes (2000, p. 15):

[...] Em 1952, o Cinerama utilizava um rolo de $35 \mathrm{~mm}$ com seis pistas independentes - cinco atrás da tela e a sexta em "surround". [...] Em 1955, o Todd-AO apresentava a mesma distribuição de canais do Cinerama, porém com bandas magnéticas aplicadas ao rolo de imagem de $70 \mathrm{~mm}$.

[...] todos os sistemas de reprodução magnética estereofônica custavam 70\% a mais do que o sistema ótico monofônico tradicional, sendo reservado para as grandes produções.

O alto custo de produção e de conversão das salas de exibição foi determinante para que a tecnologia do registro sonoro magnético ficasse restrita à captação e a pós-produção da trilha sonora enquanto o padrão dominante para a distribuição e exibição continuou sendo o sistema de som óptico.

Conforme destaca Clotilde Borges Guimarães (2008, p. 20), a substituição do registro óptico pelo sistema de gravação magnética não trouxe significativas modificações na rotina das filmagens e no método de trabalho empregado pela equipe de captação de som no Brasil. De acordo com a autora, os gravadores utilizados no registro magnético "ainda eram pesados (quase $30 \mathrm{Kg}$ ) e precisavam ser alimentados pela rede elétrica ou por geradores” para a manutenção do sincronismo entre a câmera e o gravador de som. A captação de som direto continuava demandando complexa infraestrutura e apresentando baixa portabilidade.

O depoimento ${ }^{39}$ do técnico de som direto Juarez Dagoberto, que iniciou a carreira em 1953, nos estúdios da Vera Cruz em São Paulo, relata aspectos da rotina da captação de som direto, empregando a tecnologia magnética e as dificuldades operacionais relacionadas com a baixa portabilidade do sistema empregado:

\footnotetext{
${ }^{39} \mathrm{O}$ depoimento foi colhido em entrevista realizada por Clotilde Borges Guimarães em sua pesquisa de mestrado.
} 
Os equipamentos magnéticos já tinham chegado na Vera Cruz no finalzinho dos anos 1940 e começo dos 1950, por aí. Na Vera Cruz tinha o sistema fixo ótico da RCA e também tinham os gravadores óticos que saíam no caminhão e iam para as locações, nas unidades externas e já tinham também os gravadores magnéticos de fita perfurada RCA. Eram magnéticos $35 \mathrm{~mm}$ perfurados e tinha o $17,5 \mathrm{~mm}$ perfurado. O $35 \mathrm{~mm}$ rodava a 90 pés, como as câmeras, por minuto, e com a fita perfurada o sincronismo era perfeito.

Tinha um gerador que acompanhava a gente que era o gerador do som, que era um gerador menor que abastecia de energia a câmera e o som. O sistema energético era centrado no caminhão de som. Era um caminhão inglês. Do caminhão de som, saía uma linha $220 \mathrm{~V}$ que abastecia o motor trifásico da câmera Mitchel e o sistema de som que estava plantado no caminhão. E o sincronismo era perfeito. Quem comandava a distribuição de energia era o caminhão de som. Quando o diretor pedia “câmera!", era o som que ligava. O operador, o recordista, ficava dentro do caminhão. Quando pedia "Câmera!", o recordista é que ligava a câmera e uma outra chave que ligava o gravador. Agora, o mixer, é daí que vem o termo sound mixer, ficava dentro do cenário. Então, do mixer até o caminhão vinham os cabos, e quem determinava os níveis de modulação era o sound mixer de dentro do cenário. Quando era externa era a mesma coisa. $\mathrm{O}$ sound mixer era quem modulava e o recordista, dentro do caminhão, gravava, ligava o Rec. [...] Esse gravador era chamado de portátil, mas era em termos, porque o conceito de portátil era poder andar no caminhão, porque era pesado pra burro. A gente tinha 17, 18 anos e tinha força bastante (GUIMAR ÃES, 2008, p. 20).

Mudanças nesse cenário começaram a ocorrer com o advento dos gravadores magnéticos portáteis sincrônicos de fabricação suíça, denominados "Nagra". Em 1958, a fabricante Kudelski Company disponibilizou no mercado a terceira geração de equipamentos de gravação de som portáteis, denominados "Nagra III", que se tornariam a referência para o registro de som sincrônico, permitindo novos procedimentos de trabalho e o surgimento de novas práticas de realização, em particular no âmbito da produção documentária.

Silvio Da-Rin (2004, p. 102-103) afirma que o advento dos gravadores de som portáteis, que posteriormente seriam amplamente utilizados na realização cinematográfica ficcional, resultou de uma demanda trazida pela produção do cine-jornalismo e potencializada pelo telejornalismo, a partir de 1950, por uma "tomada audiovisual direta". Segundo Da-Rin (2004, p. 102):

O newsreel, povoado por celebridades da política, dos esportes e dos espetáculos, esteve sempre em busca de melhores condições técnicas para dotar de voz as personalidades que focalizava. A reconstituição de acontecimentos verídicos em estúdio sonorizado, mesmo quando havia imagens diretas disponíveis, era em parte justificada pela dificuldade em obter em campo um registro sonoro sincrônico e de boa qualidade. Estes problemas foram potencializados com o advento da televisão. Não se tratava mais de produzir uma ou duas edições de alguns minutos por semana, mas 
várias emissões jornalísticas por dia, envolvendo política, esporte, variedades, entrevistas e reportagens dos mais diversos gêneros. Era urgente encontrar uma solução.

A necessidade pela "tomada audiovisual direta" estimulou a pesquisa para o desenvolvimento de uma tecnologia que permitisse a captação de imagens com sons sincrônicos, utilizando um aparato de produção menor e mais compacto do que aquele empregado nas realizações do cinema ficcional. Segundo Da-Rin (2004, p. 102-103), o início do telejornalismo demandava "câmeras leves e silenciosas", películas sensíveis à baixa luminosidade e gravadores magnéticos portáteis sincrônicos "que pudessem ser manipulados por equipes menos numerosas e mais ágeis", o aparato tecnológico para a nova prática de realização foi denominado como "grupo sincrônico cinematográfico leve". O advento do gravador Nagra III veio responder ao lado sonoro desta demanda.

Fernando Morais da Costa (2008, p. 132) comenta que os primeiros gravadores, Nagra I, fabricados pela Kudelski Company, foram utilizados com sucesso no jornalismo radiofônico das emissoras suíças a partir de seu lançamento, em 1952. O lançamento do Nagra III, em 1958, incorporaria avanços técnicos, desenvolvidos ao longo da década, que possibilitavam uma melhor monitoração do sinal gravado, o aumento na estabilidade da velocidade e a simplificação no fornecimento de energia, tornando a terceira geração dos gravadores Kudelski um equipamento largamente empregado na produção jornalística radiofônica. A grande procura pelo equipamento obrigou o aumento na capacidade produtiva da empresa para “dar conta do pedido de 240" unidades do gravador Nagra III no ano de 1958. As qualidades do equipamento determinam o rápido sucesso, passando a ser empregado pelas principais redes ${ }^{40}$ de jornalismo do mundo.

Apesar da fabricação do Nagra III ter sido inicialmente direcionada para as reportagens radiofônicas, o potencial técnico do equipamento foi rapidamente percebido por diferentes documentaristas que passam a utilizar o novo gravador em suas realizações no início da década de 1960.

A realização dos documentários Primárias (Primary) ${ }^{41}$, nos Estados Unidos, e Crônica de um verão (Chronique d'un été) ${ }^{42}$, na França, emblemáticos representantes das

\footnotetext{
${ }^{40}$ A RAI adotaria o Nagra III para a cobertura das Olimpíadas de Roma, realizadas em 1960. As redes norte-americanas $\mathrm{ABC}, \mathrm{CBS}$ e a inglesa $\mathrm{BBC}$ passaram a empregar o gravador como o equipamento padrão para captação de som portátil.

${ }^{41}$ PRIMÁRIAS. Direção de Robert Drew. Dist. VideoFilmes, 1960. 1 filme (60 min): son., P\&B,; 16 $\mathrm{mm}$. O filme acompanha as eleições primárias que escolheram o candidato do Partido Democrata à
} 
correntes documentárias denominadas Cinema Direto (Direct Cinema) e Cinema Verdade (Cinéma Vérité), respectivamente, empregaram basicamente a mesma tecnologia de captação $^{43}$ para a concretização de diferentes estéticas e diferentes modos de representação da realidade, em que sons e imagens são captados sincronicamente em situações do cotidiano impensáveis com a tecnologia anterior. Conforme Fernando Morais da Costa (2008, p. 134), "os documentários da passagem para a década de 1960 concretizaram, no cinema, a possibilidade da gravação sincrônica de sons e imagens virtualmente em qualquer lugar”, influenciando significativamente a prática da realização cinematográfica daquele momento em diante. Com o emprego do novo aparato técnico, continua o autor, "a filmagem parecia poder ser mais natural, capturadas as ações na própria locação, fora dos artificialismos dos estúdios". O novo aparato portátil permite abordagens que direcionam para um novo ideal de realismo. De acordo com Costa (2008, p. 134):

A maior fidelidade quanto à gravação das vozes, agora captadas, teoricamente, em quaisquer lugares e situações cotidianas, instaurava a crença em um tipo de cinema que capturava a realidade com cada vez menos artificialismo.

Silvio Da-Rin (2004, p. 105) comenta que ao contrário das reações de oposição ao som sincrônico, formalizadas por parte dos realizadores e por parcela da crítica no advento do cinema sonoro, a posição dos documentaristas diante da possibilidade de utilização quase irrestrita do som sincrônico trazida pela nova realidade técnica foi de total adesão. Segundo Da-Rin (2004, p. 105):

presidência dos Estados Unidos, em 1960, quando Kennedy enfrentou o senador Hubert Humphrey. Pioneiro no emprego dos equipamentos portáteis de captação de som e imagem nos Estados Unidos, Robert Drew renovou a tradicional estética documentária, abandonando a narração em voz over e as técnicas usuais de reportagem.

${ }^{42}$ CRÔNICA de um verão. Direção de Jean Rouch e Edgar Morin. Paris: Argos Film Anatole Bauman: Dist. First Run, 1960. (85 min), son., P\&B; 16 mm. A partir de uma enquete realizada nas ruas de Paris, com câmera e som captando as respostas dos pedestres, o documentário realiza a construção do retrato de um grupo heterogêneo de pessoas, que expressam as diferentes concepções sobre a vida e a política, suas dúvidas e angústias, seus cotidianos. A fronteira entre a ficção e o documentário é problematizada, reafirmando os princípios do método participativo de realização documentária com este filme.

${ }^{43}$ Segundo Clotilde Borges Guimarães, a câmera empregada por Robert Drew na realização de Primary era uma Auricom $16 \mathrm{~mm}$ blimpad, adaptada para trabalhar com bateria, enquanto na realização de Chronique d'un été foi usada a câmera KMT Coutant-Mathot Eclair, desenvolvida especialmente para a constituição do chamado "grupo sincrônico cinematográfico leve". A captação do som sincrônico foi realizada com o Nagra III com sistema de sincronização (Guimarães, 2008, p. 24-25). 
O princípio do assincronismo foi substituído pelo seu exato oposto, o princípio do sincronismo. O som direto era recebido como o preenchimento de uma lacuna que teria desde sempre impedido o trabalho espontâneo do documentarista.

No Brasil, da mesma forma que no contexto internacional, o aparato de captação sincrônico leve foi inicialmente empregado em produções documentárias e, assim como ocorreu fora do país, propiciou o arejamento estético da produção documentária brasileira, que graças ao novo potencial técnico possibilitou que as vozes dos personagens vistos na tela pudessem ser ouvidas com seus timbres, prosódias e acentos característicos sem a necessidade da tradicional locução explicativa sobre as imagens. Os diferentes sotaques do país começaram a ser ouvidos nos filmes documentários brasileiros a partir de 1962, quando uma unidade de captação sincrônica com um Nagra III aportou em solo brasileiro ${ }^{44}$.

- Nagra III - características técnicas e adequação às demandas de portabilidade

O Nagra III, lançado comercialmente em 1958, era um equipamento verdadeiramente portátil. O peso total do gravador com pilhas era em torno de $7 \mathrm{Kg}$, significativamente mais leve do que os equipamentos de gravação utilizados na realização cinematográfica até aquele momento. Os circuitos eletrônicos eram totalmente transistorizados, aumentando a resistência e reduzindo o consumo de energia do sistema. $\mathrm{O}$ fornecimento de energia podia ser feito por uma fonte de alimentação externa ligada à rede elétrica doméstica, regulável entre 110 ou $240 \mathrm{~V}$, ou ser alimentado internamente por um conjunto de 12 pilhas grandes. O funcionamento com pilhas comuns possibilitava o uso do gravador em praticamente qualquer lugar, sem restrições em relação à disponibilidade de energia. As dimensões ${ }^{45}$, o peso e o uso de pilhas tornavam o Nagra III adequado para as novas práticas cinematográficas que se estabeleciam.

\footnotetext{
${ }^{44}$ Sobre a chegada dos equipamentos para captação sincrônica no Brasil, e as primeiras realizações documentárias brasileiras com som direto, ver COSTA, 2008, p. 136-150. Sobre a formação dos profissionais para o emprego da nova tecnologia, ver GUIMARÃES (2008, p. 27-340).

${ }^{45}$ As dimensões do Nagra III e de seus sucessores (Nagra IV, o Nagra 4.2 e o Nagra IV-S) eram $34 \mathrm{~cm}$ de largura, $24 \mathrm{~cm}$ de profundidade e $12 \mathrm{~cm}$ da altura contando com a tampa acrílica.
} 
O suporte para a gravação era a fita magnética com $1 / 4$ de polegada de largura em carretéis abertos, as tradicionais "fitas de rolo". O equipamento permitia a utilização de carretéis de 5 ou 7 polegadas de diâmetro. Utilizando carretéis de 5 polegadas, que continham até 600 pés de material sensível, o equipamento podia funcionar com a tampa acrílica fechada, como visto na Foto 6. Nas situações de filmagem com deslocamento da equipe de captação, o gravador era carregado pendurado no ombro do operador por meio de uma alça de couro afixada nos parafusos laterais, próximos ao painel frontal.

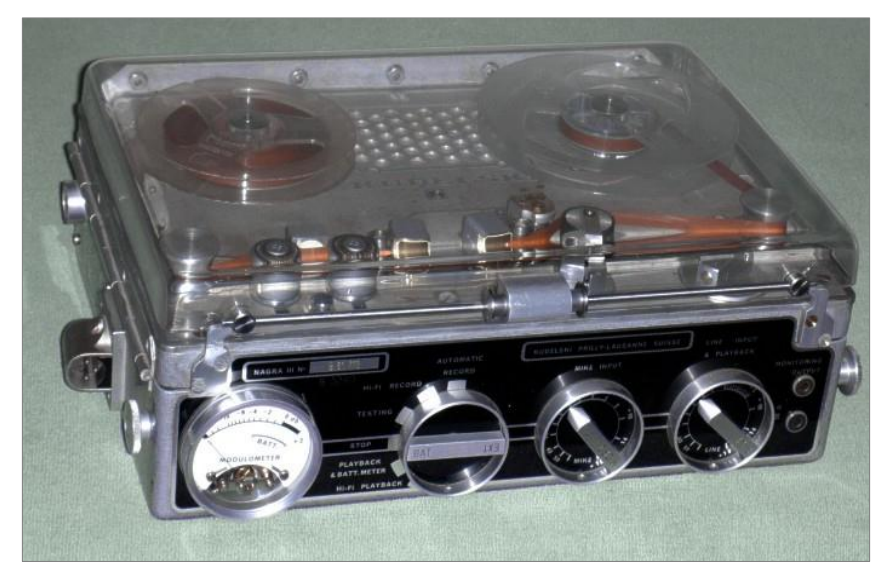

Foto 6 - Nagra III com carretéis de 05 polegadas de diâmetro.

O Nagra III possuía três velocidades de arraste da fita: 3 3/4 ips (inches per second), 71/2 ips e 15 ips. A velocidade influenciava diretamente a qualidade da gravação: quanto mais alta a velocidade, melhor o registro sonoro, pois no sistema analógico magnético, quanto maior a área de material sensível utilizado, melhor a qualidade da gravação.

A utilização de carretéis de 7 polegadas, com 1200 pés de material sensível rodando à velocidade intermediária (utilizada normalmente para a captação de diálogos), possibilitava gravações com 32 minutos de duração. Com carretéis de 7 polegadas, era necessário manter a tampa acrílica aberta, como vemos na Foto 7, num arranjo possível para tomadas sem deslocamento da equipe de captação. 


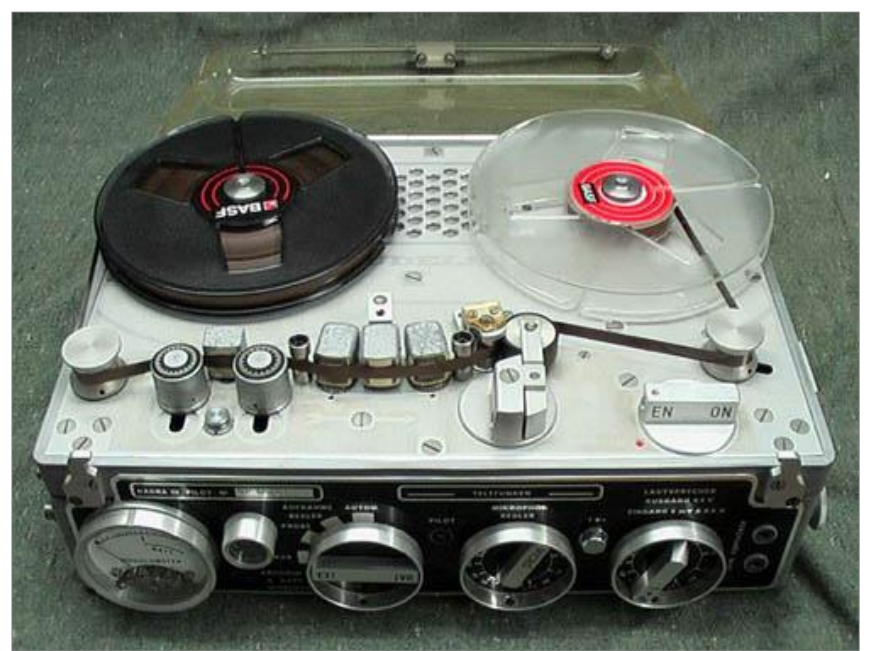

Foto 7 - Nagra III com carretéis de 07 polegadas de diâmetro.

A gravação do sinal de áudio no Nagra III, com qualidade considerada igual ou superior àquela obtida nos gravadores de fita magnética perfurada, era realizada em uma única pista que ocupava praticamente toda a largura da fita magnética. Este formato de gravação era denominado full track. O padrão "pista cheia" permitia apenas gravações monofônicas em um único lado da fita.

O Nagra III dispunha de uma entrada para sinal de microfone ${ }^{46}$ com o ganho controlado pelo potenciômetro da esquerda no painel frontal e uma entrada para sinal de linha ${ }^{47}$ (que podia ser convertida para sinal de microfone com a utilização de um acessório externo) com o ganho controlado pelo potenciômetro da direita. A chave seletora de funções ficava ao lado do modulômetro. O Nagra III podia receber, simultaneamente, o sinal de vários microfones com a utilização de uma mesa de mixagem conectada à entrada de linha. No processo de realização cinematográfica, o som direto original registrado pelo Nagra era transferido (regravado) para magnético perfurado para a montagem na moviola. As fitas originais do som direto eram armazenadas para futuras retranscrições.

O sistema de sincronização Pilotton, desenvolvido pela Kudeslki, em 1961, garantia perfeito sincronismo entre o Nagra III e as câmeras movidas por baterias que constituíam o "grupo sincrônico cinematográfico leve". O sistema consistia na gravação de um sinal "piloto", gerado no gravador a partir de uma referência extraída do pulso do motor da câmera,

\footnotetext{
${ }^{46}$ Sinal elétrico de pequena magnitude, geralmente medido em milivolts. O circuito eletrônico que recebe este sinal deve ser compatível com a sua grandeza.

${ }^{47}$ Sinal elétrico de maior intensidade, geralmente em torno de 1 volt. É o sinal disponibilizado na saída de outros gravadores ou das mesas de mixagem.
} 
simultaneamente ao registro do som da tomada. O sinal piloto gravado na fita era usado como referência para controlar a velocidade do gravador durante a reprodução do áudio na transcrição para o magnético perfurado. Se durante uma tomada a câmera rodasse sem nenhuma variação de velocidade, o sinal "piloto" não sofreria variação alguma e a velocidade do gravador seria mantida de forma constante durante a reprodução. No entanto, se a câmera sofresse alguma variação de velocidade, o sinal "piloto" registraria as variações que alterariam proporcionalmente a velocidade de reprodução do gravador durante a transcrição. Assim, câmera e gravador variariam igualmente, mantendo o sincronismo.

Com o Nagra III, o equipamento que comparava o sinal piloto gravado na fita e controlava a velocidade de reprodução durante a transcrição era denominado sincronizador. Se a variação da velocidade da câmera fosse muito grande, o som continuaria sincronizado, porém, em função da alteração de velocidade, ocorreria a mudança de timbre durante a reprodução. Em 1962 o sistema foi aperfeiçoado e rebatizado como "Neopilot". Inicialmente estes sistemas pressupunham a utilização de cabo entre o gravador e a câmera, o que resultava em amarras desconfortáveis para o processo de realização. Este obstáculo para a total liberdade entre câmera e gravador foi superado com o desenvolvimento dos motores de câmera controlados por osciladores de cristal de quartzo, criados pela Kudeslki, que mantinham a velocidade das câmeras sem variação. Para garantir a transcrição sincronizada, os gravadores Nagra III e seus sucessores (Nagra IV e 4.2) passariam a receber o sinal "piloto" de um gerador de cristal de quartzo interno ao gravador.

O modulômetro (modulometer) foi uma inovação da Kudeslki, que acompanhou o lançamento do Nagra III. O modulômetro é um preciso instrumento de medição visual do nível do sinal de áudio. Com sofisticada construção, o modulômetro indicava o nível médio de modulação e cada um dos picos do sinal que trafegava pelo circuito do gravador (mesmo transientes de curta duração). Este instrumento capacitava o técnico de som a controlar com grande exatidão o nível de gravação do som direto.

Para a monitoração auditiva, o Nagra III disponibilizava uma saída de fone de ouvido com um sinal claro e transparente. Durante a gravação, no modo default de monitoração, o sinal gravado (registro sonoro efetivamente impresso na fita - tape signal) proveniente da cabeça de reprodução era enviado diretamente aos fones de ouvido. Em função da distância que a fita percorria entre as cabeças de gravação e reprodução, esse sinal era percebido com um pequeno atraso em relação à ação que o originou. Apesar deste inconveniente, a monitoração do tape signal é de fundamental importância na prática profissional, pois permite 
ao técnico de som avaliar a qualidade do áudio efetivamente registrado na fita. Possíveis falhas na emulsão magnética ou alterações no timbre do som original, causadas por uma resposta irregular da fita, podem ser claramente percebidas quando o tape signal é monitorado. No Nagra III, por meio do acionamento de um interruptor de pressão localizado no painel frontal, era possível ouvir temporariamente o sinal direto recebido pelo gravador antes de ser gravado (direct signal). Um procedimento usual durante a gravação era a alternância entre os dois sinais (tape/direct signal), a qual permitia avaliar auditivamente a "coloração" sonora que uma determinada emulsão magnética gerava sobre o som captado.

O modelo "Nagra 4.2", lançado em 1971, aprimorou o sistema de monitoração auditiva, incorporando uma chave comutadora ${ }^{48}$ que permitia ao técnico de som escolher o sinal a ser ouvido durante a gravação. Essa função se tornou uma ferramenta obrigatória nos equipamentos destinados ao uso profissional.

O Nagra III e seus sucessores diretos (Nagra IV e Nagra 4.2) davam continuidade ao usual procedimento de gravação do som direto em uma única pista. Para a estratégia de captação de som com vários microfones simultaneamente era empregado um console de mixagem e os diversos canais eram mixados "ao vivo" durante a gravação. O técnico de som dosava o ganho de cada canal, aumentando ou diminuindo o nível de cada microfone, conforme o desenvolvimento da tomada. A única pista resultante era precisamente monitorada durante a captação, permitindo a exata avaliação da qualidade do registro sonoro. O potencial de erro envolvido neste procedimento era alto, pois as correções de ganho dependiam da habilidade e sensibilidade do profissional envolvido. Mesmo com o advento dos gravadores portáteis com duas pistas ${ }^{49}$, o procedimento tradicional não foi significativamente alterado. Em situações de captação com múltiplos microfones, o técnico de som roteava os canais para cada uma das pistas disponíveis, monitorando prioritariamente aquela que recebia o microfone (ou microfones) considerado mais importante na estratégia de captação adotada.

O som direto obtido a partir do arranjo "pista única" permitia ao técnico de som uma monitoração precisa do material captado, garantindo uma exata avaliação da qualidade do

\footnotetext{
${ }^{48}$ A chave comutadora denominada de "tape/direct switch" localizada no painel frontal do gravador, podia ser acionada a qualquer momento durante a gravação. O técnico de som selecionava o sinal que seria enviado aos fones de ouvido, assim podia monitorar o sinal gravado ou o sinal direto permanentemente.

${ }^{49}$ Em 1971, a Kudelski lançou o Nagra IV-S, equipamento com duas pistas de gravação (half track), inicialmente projetado para gravação musical estereofônica, que passou a ser largamente empregado na realização cinematográfica. Na década 1990, com o emprego da tecnologia do som digital, os equipamentos DAT foram padronizados com duas pistas de gravação.
} 
registro sonoro enviado à pós-produção. Esta prática de trabalho seria profundamente alterada com a chegada, no início da década de 2000, dos gravadores multipistas portáteis digitais.

- Superando a limitação do quadro - os microfones de lapela sem fio

Durante a década de 1970, a evolução da tecnologia e a miniaturização dos sistemas eletrônicos permitiram o desenvolvimento dos microfones de lapela, os quais podiam ser ocultados no corpo dos atores, geralmente sob a roupa, enviando o sinal de áudio ao gravador através de um sistema de radiotransmissão sem a necessidade de conexão física via cabos. Por isso, ficaram conhecidos como "microfones de lapela sem fio" (wireless microphone). No processo de realização do cinema convencional, o desenvolvimento destes dispositivos permitiu a superação da tradicional condição imposta ao som direto pelo posicionamento do microfone fora do quadro estabelecido pela câmera. Como usualmente os microfones não deveriam ser revelados em campo, o seu posicionamento era dependente da imagem. Com os microfones de lapela sem fio, a demanda pela captação das falas com sonoridade de contínuo close-up, manifestada desde os primórdios do cinema sonoro, pode ser satisfeita, mantendo o microfone constantemente próximo à fonte sonora independentemente do tamanho do quadro definido pela câmera. A despeito das considerações que faremos no próximo capítulo acerca da característica sonora dos microfones de lapela e dos problemas inerentes a sua utilização, esses dispositivos tornaram-se ferramentas indispensáveis ao trabalho do técnico de som direto.

A disseminação do uso dos microfones de lapela na década 1970 estimulou o surgimento de procedimentos de captação e registro do som direto, os quais diferiam da proposta usual de gravação em uma única pista. Um exemplo de experiência inovadora no registro sonoro cinematográfico, explorando o potencial de captação oferecido pelos microfones de lapela sem fio, foi o trabalho desenvolvido por Jim Webb em parceria com Robert Altman, que garantiu, em relação ao som direto, a concretização da proposta de direção buscada por Altman.

Em 1974, Webb passou a utilizar um sistema de gravação multipista, adaptando um equipamento de 8 pistas empregado originalmente em gravação musical para o registro 
sincrônico em produções cinematográficas de longa-metragem ${ }^{50}$. Esse sistema permitia a captação de até 8 canais de áudio sem a necessidade de mixá-los na gravação. O registro sonoro de cada um dos microfones captados simultaneamente podia ser trabalhado independentemente durante a edição e a mixagem, conforme o interesse narrativo/dramático definido pelo diretor. Jim Webb antecipou-se quase trinta anos em relação à mudança de procedimentos, que ocorreriam em meados da década de 2000, na captação e registro do som direto, resultante da popularização das plataformas digitais portáteis multipistas. A utilização do inovador sistema revelou precocemente à Webb a impossibilidade de monitorar o registro sonoro multipista com a mesma precisão empregada na gravação em pista única. Em entrevista concedida a Vincent LoBrutto (1994, p. 72), Jim Webb relata o procedimento empregado para monitorar e controlar os níveis da gravação multipista durante a filmagem de Jogando com a sorte (California Split) ${ }^{51}$. Segundo Webb:

The best way to describe trying to listen to eight things going in mono is really kind of a Tower of Babel. The best thing you could do was go through and sample everything just before the shot and make sure it was functioning. Then it became a matter of watching meters and laying tracks down at 100 percent. [...] I could use a selector switch and go through and sample each track. It was very awkward (WEBB apud LOBRUTTO, 1994, p. 72).

A resposta de Webb é reveladora da necessidade de uma mudança paradigmática no método de trabalho do técnico de som, que abdica da precisão auditiva na monitoração do sinal gravado para adequar-se ao novo sistema de gravação. Nesse sistema, o técnico de som tem menor possibilidade de avaliar com exatidão a qualidade do trabalho realizado durante a captação, transferindo para a pós-produção um material sonoro mais indefinido. As dificuldades oriundas desta mudança de paradigma seriam fortemente sentidas pelos técnicos de som que, na década de 2000, migraram para as plataformas digitais portáteis multipista.

\footnotetext{
${ }^{50}$ Para detalhes do desenvolvimento do sistema multipista criado por Webb e os filmes realizados em parceria com Robert Altman, ver LoBrutto, 1994, p. 69-82.

${ }^{51}$ JOGANDO com a sorte. Direção de Robert Altman. 1974. (108 min): son., color,; 35 mm.
} 
- A tecnologia digital aplicada ao som direto

Na década de 1990, com o avanço da tecnologia digital, a indústria eletrônica disponibilizou novos equipamentos para o registro sonoro, denominados "digital audio tape" (DAT). Estes gravadores acabaram por desbancar a hegemonia dos equipamentos Nagra na produção cinematográfica. Utilizando a tecnologia digital para a representação sonora, os gravadores DAT foram inicialmente desenvolvidos para o mercado fonográfico, porém rapidamente passaram a ser utilizados na captação de som direto. Os gravadores DAT apresentavam velocidade estável e excelente qualidade sonora sem o inconveniente ruído de fita (tape hiss ${ }^{52}$ ), característico das gravações analógicas magnéticas. Logo no início da década de 1990, a indústria disponibilizou modelos portáteis profissionais (ver Foto 8) a um preço médio $50 \%$ menor que o antecessor analógico, influenciando a gradual substituição de tecnologia.

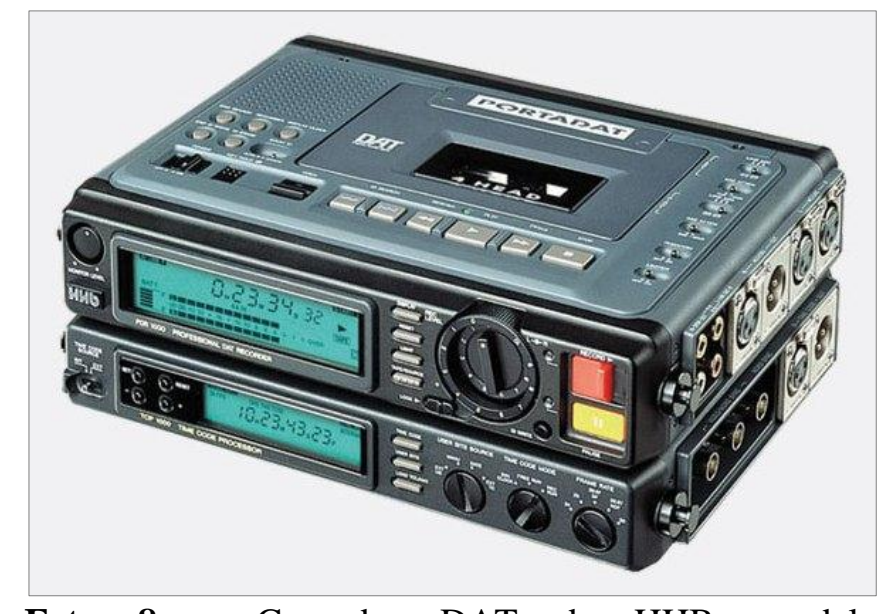

Foto 8 - Gravador DAT da HHB, modelo PORTADAT PDR 1000 com módulo de time code.

No início da década de 2000, novas plataformas de registro chegaram ao mercado e deram início a um processo de mudança de paradigma na captação e registro de som direto: os gravadores digitais portáteis multipista não lineares. Eles são máquinas portáteis, com excelente qualidade sonora, que registram a informação digital em mídias sólidas, possibilitando acesso não-linear ao material gravado e disponibilizando várias pistas

${ }^{52}$ Tape hiss é um ruído de alta frequência encontrado nas gravações magnéticas analógicas, resultante do atrito das partículas magnéticas na cabeça de gravação e reprodução durante o arraste da fita. $\mathrm{O}$ "ruído de fita" é inerente ao processo de gravação analógica e aumenta de intensidade a cada nova geração do sinal gravado. 
independentes de gravação. A chegada desses equipamentos modificou a prática de captação e registro do som direto, repercutindo também nos procedimentos de montagem e edição sonora.

Analisaremos o potencial dessa nova ferramenta e suas implicações na prática de trabalho do técnico de som direto durante a descrição das estratégias de captação de som empregadas na realização do longa-metragem Antônia, no capítulo 4. 


\section{A PRÁTICA DE CAPTAÇÃO DO SOM DIRETO}

Por definição, som direto é o som captado e registrado em sincronia com as imagens em uma realização audiovisual. O vínculo da captação simultânea entre som e imagem foi determinante no desenvolvimento das práticas de trabalho do som direto.

Conforme Bordwell (1997a, p.334) o advento do filme sonoro determinou mudanças nos procedimentos de realização cinematográfica. No período da transição para o sonoro, novas práticas foram estabelecidas para adequar a realização às necessidades de captação e de registro do som. Em algumas situações o som direcionou as estratégias de filmagem, como no emprego de múltiplas câmeras como tentativa de superar as limitações impostas pela tecnologia de gravação do som em discos, conforme visto no capítulo anterior. A tendência da indústria cinematográfica foi a de desenvolver tecnologia e adequar os procedimentos de trabalho no sentido de inserir o som num esquema de produção já estabelecido. Os avanços tecnológicos buscaram: aumentar a qualidade dos sistemas eletrônicos de captação e reprodução; criar equipamentos (câmeras e luzes silenciosas, suportes para microfone) e infraestrutura (estúdios acusticamente tratados) compatíveis com as necessidades do registro de som que se inseria, como um novo elemento narrativo, no sistema de representação solidamente constituído pelo cinema clássico de Hollywood.

A fidelidade na representação dos eventos acústicos é compartilhada por diversas áreas profissionais que lidam com a matéria sonora (indústria fonográfica, produção radiofônica, espetáculos musicais, etc.), e a qualidade do som direto é igualmente orientada por esta premissa. Porém, no som direto os procedimentos empregados estão condicionados à captação simultânea da imagem que, via de regra, determina que os dispositivos de captação estejam fora de quadro, limitando o posicionamento dos microfones. É com esta premissa que se organiza o método de trabalho do som direto.

Numa realização audiovisual convencional, espera-se que o áudio gravado pelo som direto: a) tenha um registro de voz claramente inteligível; b) ocupe um plano sonoro verossímil à imagem correspondente ou que possa ser manipulado em pós-produção para alcançar esta verossimilhança; c) entre os planos que constituem uma sequência, tenha continuidade de timbre e adequação com o espaço fílmico representado; d) forneça os elementos necessários para a edição de som, com os ambientes próprios das locações, com os planos sonoros de cobertura e com os ruídos de características especiais, difíceis de serem recriados na pós-produção. 
No atual estágio da realização cinematográfica ficcional, os técnicos responsáveis por essa função apresentam elevado grau de especialização e atuam na maioria das vezes como freelancers no mercado de trabalho. Estes profissionais têm a incumbência de determinar os procedimentos que objetivam a obtenção de registros sonoros com características técnicas que permitam integrá-los à trilha sonora finalizada. Não obstante as enormes diferenças orçamentárias existentes entre as produções ao redor do mundo, que determinam estruturas de realização bem distintas, é possível localizar procedimentos recorrentes que formam a base de uma prática de captação de som direto.

Neste capítulo serão apresentadas as diferentes configurações técnicas empregadas na captação de som direto e as atividades práticas realizadas pelo técnico de som desde a preparação desenvolvida na pré-produção até a etapa de captação propriamente dita.

\subsection{CONFIGURAÇÃO TÉCNICA E CONSTITUIÇÃO DA EQUIPE}

A realidade orçamentária, o objetivo do projeto audiovisual e as demandas do roteiro condicionam a configuração dos equipamentos e a constituição da equipe responsável pelo registro do som sincrônico. Além desses fatores, o tipo de suporte escolhido para o registro da imagem é também determinante. Atualmente, quando se trabalha captando a imagem em película usando câmeras cinematográficas, obrigatoriamente o registro sonoro será feito separadamente, em um gravador de som independente, numa configuração denominada de double system ${ }^{53}$. Em contraposição, nas produções audiovisuais, em que câmeras de vídeo digital são usadas para registrar a imagem, o som pode ser gravado conjuntamente no mesmo suporte, constituindo o chamado single system ${ }^{54}$.

Nas produções em vídeo digital, a opção por gravar o som e a imagem no mesmo suporte é uma decisão influenciada por questões que dizem respeito a: os custos de produção; a maior ou menor necessidade de "independência do técnico de som em relação à câmera"; o tempo disponível para a pós-produção; e qualidade técnica desejada, conforme apontam Alejandro Seba e Leandro Loredo no texto Sonido directo - algunas consideraciones (2005,

\footnotetext{
${ }^{53}$ A captação em double system foi uma prática dominante no registro cinematográfico desde o advento da captação óptica em câmera separada da imagem em meados de 1929.

${ }^{54} \mathrm{Na}$ prática da realização, o termo é normalmente empregado em inglês.
} 
p. 64). Diferentes configurações técnicas impõem ao profissional do som diferentes condições de trabalho, como veremos a seguir.

Considerando as produções em vídeo digital, a opção por registrar o som em double system significa arcar com custos de locação de um gravador de som, além do custo obrigatório com a câmera de vídeo. Apesar de existir uma infinidade de marcas e modelos de gravadores, com imensa variação de preço, alguns projetos audiovisuais de baixo orçamento só se viabilizam por meio de esquemas extremamente econômicos, os quais suprimem itens que isoladamente representam um pequeno valor. Além do custo de locação, o double system acarreta um custo a mais ao processo de realização audiovisual, pois cria a necessidade de sincronizar som e imagem antes de iniciar a edição; em contraposição, no single system som e imagem são fisicamente sincronizados no momento da captação. Nos projetos em que o tempo para a pós-produção é escasso, o carregamento do material na ilha de edição já sincronizado é um argumento fortíssimo em favor do single system.

A realização de matérias jornalísticas para a televisão tem como premissa a configuração single system em função da maior rapidez no processo de finalização. Considerando exclusivamente a qualidade do áudio digital, sabemos que, embora "a taxa de amostragem $^{55}$ e o bit depth ${ }^{56}$ sejam similares nas câmeras de vídeo digitais e nos gravadores de som, nestes últimos, por serem destinados exclusivamente ao registro sonoro, contarão com conversores analógico-digital/digital-analógico $(\mathrm{AD} / \mathrm{DA})^{57}$ de maior qualidade e outros acessórios que garantem melhores resultados" no registro sonoro digitalizado (SEBA; LOREDO, 2005, p. 64).

Podemos esquematizar as diferentes configurações técnicas para a captação de som direto, das mais simples às mais complexas, do seguinte modo:

\footnotetext{
${ }^{55}$ Taxa de amostragem ou sampling rate é a frequência de amostras do som original, colhidas para serem representadas numericamente. A taxa de amostragem normalmente empregada na captação de som direto é de $48 \mathrm{KHz}$. Na indústria fonográfica, a taxa de amostragem utilizada na confecção dos compact discs é de $44,1 \mathrm{KHz}$.

${ }^{56} \mathrm{O}$ bit depth é um dos parâmetros que determinam a qualidade do som digital. Bit depth é a magnitude de cada número utilizado para representar o som contido em cada pequena fração de tempo utilizada na amostragem - sampling rate - do sinal sonoro original. Quanto maior o bit depth, maior o intervalo dinâmico alcançado pelo som digital. Atualmente, na captação de som direto são empregadas taxas de 16 ou 24 bits.

${ }^{57}$ Conversores $\mathrm{AD} / \mathrm{DA}$ são microprocessadores que transformam sinais analógicos em sinais digitais e vice-versa. A qualidade do processo de conversão analógico-digital/digital-analógica é determinada pelas características técnicas desses dispositivos.
} 
- Single system - som e imagem gravados no mesmo suporte.

a. Microfones conectados diretamente à câmera de vídeo.

b. Microfones conectados a um mixer portátil que se conecta à câmera de vídeo.

-Double system - som e imagem registrados em suportes independentes.

a. Microfones conectados a um mixer portátil que se conecta a um gravador digital portátil. Equipamentos presos ao corpo do técnico de som. Alta portabilidade.

b. Microfones conectados a um mixer ou console de mixagem que se conecta a um gravador digital. Equipamentos instalados em plataforma fixa ou em um carrinho de som. Baixa portabilidade.

A primeira configuração é a mais vantajosa em termos orçamentários, porém limita muito o trabalho do técnico de som direto. O controle de ganho do sinal de áudio fica localizado no corpo da câmera, com difícil acesso para o técnico de som, impedindo correções de volume durante a captação da cena. Nessa configuração não é disponibilizado instrumento de monitoração visual do volume do som captado e a monitoração auditiva é de baixa qualidade e desajeitada, pois é feita por meio de uma longa extensão que conecta o fone de ouvido do técnico de som à saída de fone da câmera. Além dessas restrições, acrescenta-se o fato de que o número de microfones é determinado pela quantidade (geralmente dois) de canais de áudio disponíveis na câmera, e não pelas necessidades da cena. Essa configuração é usada apenas em produções de baixíssimo orçamento e sem maiores pretensões em relação à qualidade do som.

Um arranjo ainda mais simples que esse pode ser constituído pela fixação de um microfone no corpo da própria câmera, procedimento pouco usual em realizações profissionais, porém muito útil e eficiente em algumas situações particulares como veremos no próximo capítulo, na descrição do filme Contra todos.

O segundo arranjo do single system, com a presença de um mixer portátil, proporciona condições mais apropriadas ao trabalho do técnico de som direto. É disponibilizada no mercado dos produtos eletrônicos profissionais uma infinidade de modelos que atendem a 
diferentes necessidades de captação. Entre as características básicas, encontradas na maioria dos mixers, podemos citar: os potenciômetros que permitem o ajuste de ganho individual para cada canal, proporcionando o controle dinâmico do volume do áudio captado; os filtros para a atenuação de ruídos indesejados; os $\mathrm{VUs}^{58}$ e/ou os peakmeters ${ }^{59}$ que possibilitam a monitoração visual do nível do áudio captado; e a saída de fone de ouvido com sinal transparente, volume ajustável e ganho adequado que disponibilizam uma referência auditiva confiável do material captado. Além dessas ferramentas fundamentais para o controle da captação, os mixers portáteis, com grande variedade de modelos, oferecem até seis canais de entrada, possibilitando ao técnico de som o emprego de um maior número de microfones para a execução de estratégias mais complexas de captação. A maioria dos mixers portáteis possui duas saídas principais mixadas (master output), por meio das quais se envia o sinal de áudio para a câmera. A principal limitação dessa configuração é a conexão física, feita por intermédio de cabos, com a câmera de vídeo, situação que restringe o livre deslocamento e obriga o técnico de som a posicionar-se em função das escolhas da câmera. Esse "cordão umbilical" pode tornar-se um estorvo em situações com deslocamento intenso da equipe, como em gravações de rua ou festas populares, comuns nas realizações documentárias que empregam o single system com bastante frequência.

Uma configuração mais sofisticada desse sistema permite que a conexão entre o mixer e a câmera seja estabelecida via rádio, suprimindo o "cordão umbilical" que limita a movimentação da equipe. No entanto, sistemas de radiotransmissão eficientes são onerosos e criam uma exigência desgastante: a contínua monitoração do sistema de transmissão. Considerando que, o funcionamento do sistema de transmissão via rádio é dependente do fornecimento de energia de baterias internas dos transmissores e receptores, e que a interrupção do sinal, pela queda de energia, pode invalidar uma cena, cabe ao técnico de som, além de todas as atividades para a captação do som, dedicar atenção contínua para garantir o funcionamento ininterrupto do sistema de transmissão.

O double system possibilita a independência em relação à câmera e é a configuração técnica mais complexa. A existência de uma plataforma específica para o registro do áudio desfaz o "cordão umbilical" e possibilita o controle total sobre o registro do áudio com as

${ }^{58} V U$ é a abreviatura de Volume Unit, dispositivo padrão usado para medição do nível médio do sinal de áudio. Instalado em diversos equipamentos de som, ele possui tempo de resposta semelhante à audição humana, o que possibilita a avaliação da chamada "sensação de volume de um sinal de áudio". ${ }^{59}$ Peak Meter é um dispositivo de medição de intensidade sonora que reage instantaneamente aos sinais que transitam no sistema, propiciam a monitoração visual dos curtos transientes elétricos que podem causar distorção do sinal sonoro por excesso de intensidade. 
ferramentas adequadas para: a monitoração do registro sonoro, o ajuste do nível do sinal de áudio e a filtragem de ruídos.

Os equipamentos de som na configuração double system podem ser estruturados num arranjo compacto, com os aparelhos presos ao corpo do técnico de som direto, buscando o máximo de portabilidade. Essa conformação é largamente empregada em produções documentárias que normalmente exigem rapidez no deslocamento e uma estrutura enxuta de captação. Normalmente nessas situações, a equipe de som direto é constituída por um único profissional que executa todas as funções exigidas para o registro do som. A Foto 9 ilustra a configuração double system empregada na realização do documentário La terre et la peine ${ }^{60}$. Num típico arranjo para a realização documentária, o técnico de som realiza o registro sonoro, ao mesmo tempo em que opera o microfone. Na foto, é possível ver o uso do microfone direcional sustentado pelo boom $^{61}$.

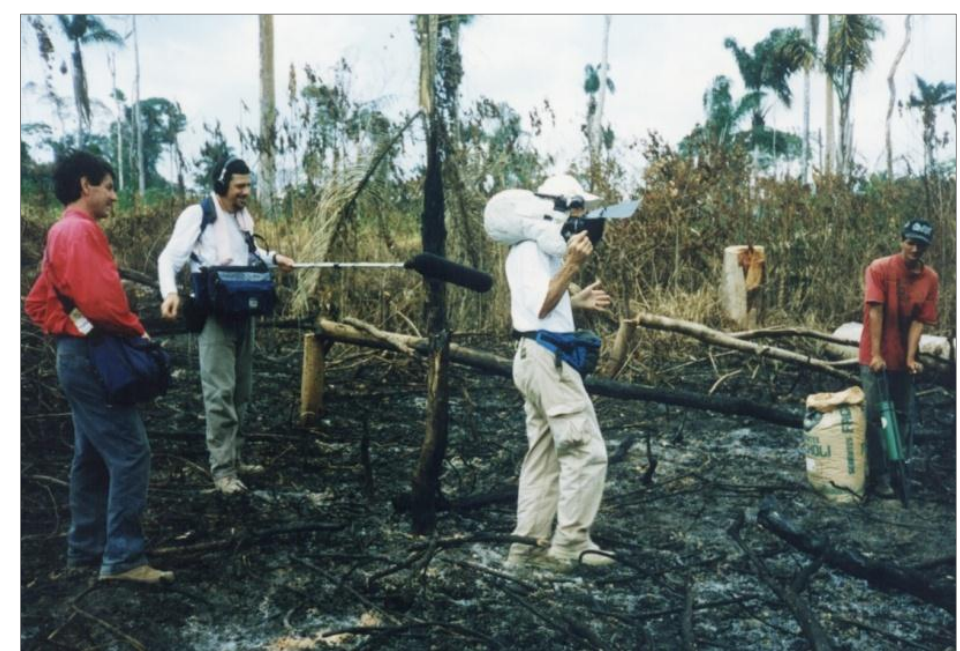

Foto 9 - Equipe de captação configurada em double system portátil com gravador analógico Nagra e câmera Aaton super $16 \mathrm{~mm}$.

Tecnicamente, essa configuração disponibiliza ao profissional do som as ferramentas adequadas para a realização do trabalho à custa de um enorme esforço físico. Cuidar ${ }^{60}$ A TERRA . Direção de Frédéric Létang. 1997. 1 filme (90 min): son., color,; 35 mm.

${ }^{61}$ No Brasil, o termo boom é usado para indicar o dispositivo tubular leve, com extensão ajustável e que suporta o microfone. O microfonista sustenta esse dispositivo com os braços, posicionando o microfone para a captação do som. Nos Estados Unidos, o termo boom é usado para designar o suporte de microfone, normalmente construído sobre rodas, com uma longa vara metálica, que carrega o microfone, sustentada por um eixo central. Esse sistema é operado pelo boom operator por meio de manivelas; seu emprego é muito comum em gravações de sitcom. Fishpole ou mic boompole, termo usado para designar o suporte de microfone leve, sustentado com os braços pelo boom operator. 
simultaneamente do registro sonoro e da operação do microfone direcional, carregando uma considerável sobrecarga de peso - que pode chegar facilmente a dez quilos -, exige disposição e resistência física.

A Foto 10 ilustra uma situação relativamente comum na realização documentária, na qual, durante uma tomada, o técnico de som necessita controlar o ganho do microfone. Dessa forma, com uma das mãos o técnico suporta o boom, mantendo o microfone na posição correta para a captação e com a outra faz o ajuste necessário para o controle do nível de gravação.

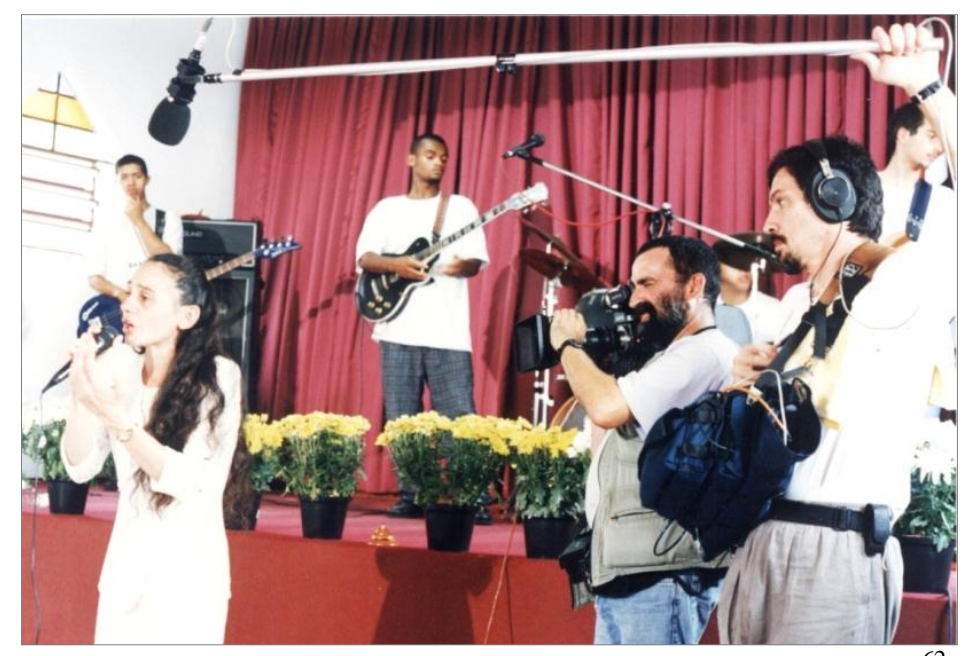

Foto 10 - Equipe de captação do documentário $F e^{62}$, configurada em double system portátil: gravador DAT, mixer e câmera Aaton super $16 \mathrm{~mm}$.

$\mathrm{Na}$ realização de longas-metragens ficcionais é empregada a configuração double system com os equipamentos de som, normalmente, num arranjo de menor portabilidade com o técnico de som direto trabalhando numa situação mais confortável. É comum a disposição dos equipamentos sobre uma plataforma móvel denominada "carrinho de som", que permite que os componentes (mixer, gravador, microfones) estejam conectados e prontos para uso. $\mathrm{O}$ “carrinho de som" possibilita a organização dos equipamentos e acessórios que são utilizados corriqueiramente e permite pequenos deslocamentos, com certa agilidade e pouco esforço, sem a necessidade de desmontar o sistema. Nessas situações, a quantidade de equipamentos alocados é normalmente maior, dependente da demanda e do orçamento da produção. São comumente empregados: amplo conjunto de microfones; mixer de mesa; gravador multipista;

${ }^{62}$ FÉ. Direção de Ricardo Dias. Superfilme: Dist. Riofilme, 1999. (91 min), son., color,; 35 mm. 
monitor de vídeo para referência visual da cena captada; sistema de comunicação com o microfonista; sistema de rádio para transmissão do áudio captado para a direção e continuísta; entre outros. As necessidades de realização determinam o tipo de arranjo técnico empregado, e a organização do sistema é fundamental para a eficiência do trabalho do som direto.

Na Foto 11, há o técnico de som, durante a tomada de uma cena, com os equipamentos dispostos sobre a plataforma móvel, "carrinho de som", num típico arranjo utilizado em longas-metragens. A composição da equipe de som direto varia também em função da realidade orçamentária da produção, porém, em geral, integram a equipe, além do técnico de som, ao menos um microfonista e um assistente de som com funções que seguem um protocolo rigidamente definido, como veremos adiante.

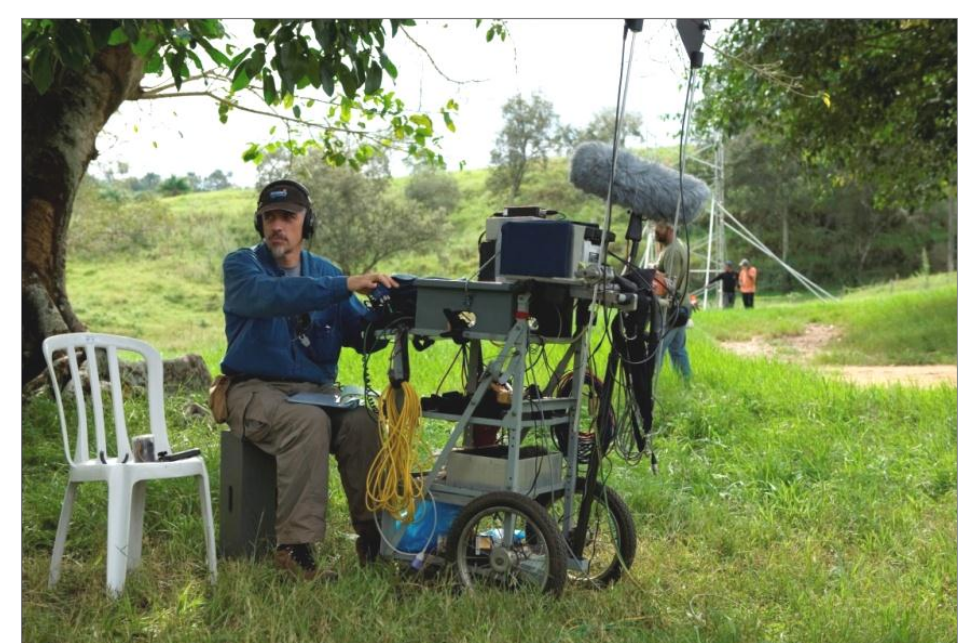

Foto 11 - Configuração double system com portabilidade reduzida. Tomada de cena do longa-metragem $O$ menino $d a$ porteira $^{63}$, em 2008, na cidade de Brotas/SP.

O emprego de arranjos de alta portabilidade não é exclusividade de realizações documentárias. Demandas específicas na realização ficcional exigem também esquemas ágeis e compactos. Entre os técnicos de som de São Paulo, é empregado o jargão "esquema voador" para designar estas configurações. Nessas situações, o técnico de som é assistido pelos demais componentes da equipe, porém, no momento da captação, opera o equipamento num arranjo semelhante àquele empregado nas realizações documentárias.

${ }^{63}$ O MENINO da porteira. Direção de Jeremias Moreira Filho. Moracy do Val: Dist. Sony Pictures, 2009. (94 min), son., color,; $35 \mathrm{~mm}$.. 
Como pode ser visto na Foto 12 e na Foto 13, nas quais foi utilizado o "esquema voador" para ocupar o interior do porta-malas do veículo usado na realização da cena com diálogo.

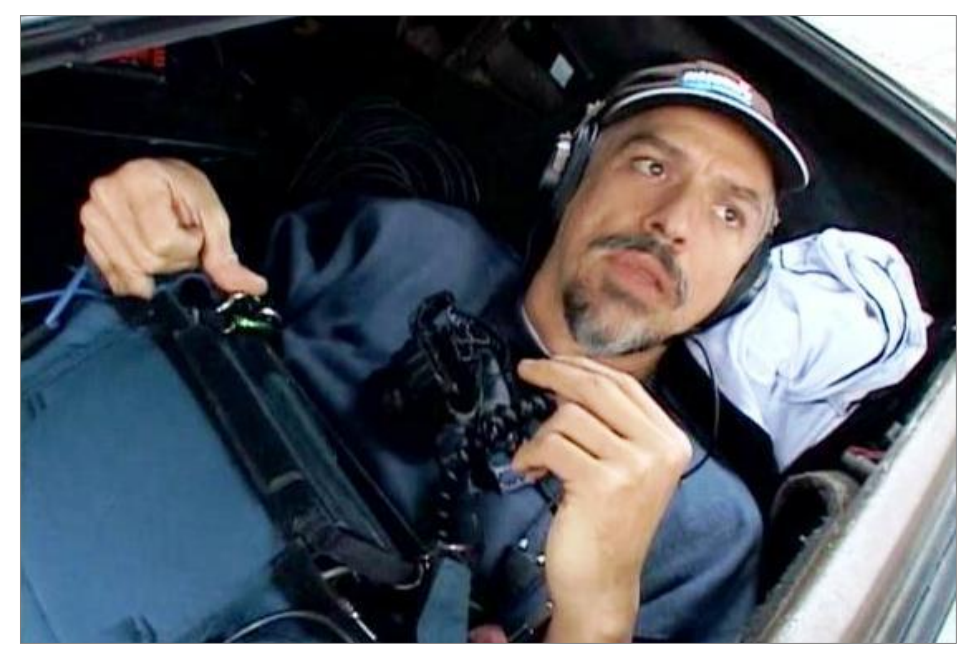

Foto 12 - Configuração double system com alta portabilidade. Tomada de cena do longa-metragem Não por acaso $^{64}$, em 2006, na cidade de São Paulo/SP.

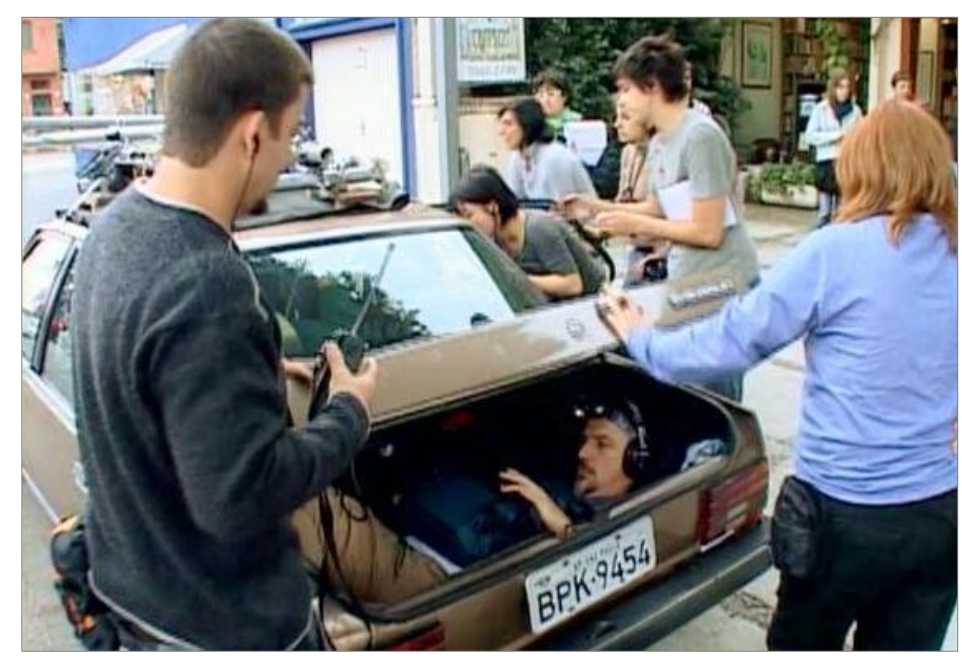

Foto 13 - Configuração double system com alta portabilidade.

A configuração dos equipamentos e as atividades desenvolvidas pelo técnico de som direto devem ser entendidas como rotinas de um método de trabalho que visa adequar-se às condições orçamentárias e à proposta estética da realização. Esse método tem procedimentos

${ }^{64}$ NÃO POR ACASO. Direção de Philippe Barcinski. Globo Filmes: Dist. Fox Filmes do Brasil, 2007. 2 filmes (90 min): son., color.; $35 \mathrm{~mm}$. 
comuns que se repetem em realidades de produção muito distintas, formando uma mesma base de trabalho compartilhada pela maioria dos profissionais da área. Porém, esses procedimentos apresentam aspectos particulares, desenvolvidos para solucionar as demandas específicas de cada produção.

Trabalha-se com a ideia de método que vai além daquele empregado pela ciência clássica, que entende o método como um programa que normatiza previamente uma série de procedimentos que serão realizados, prevendo erros evitáveis, objetivando um resultado prédeterminado. Esse sentido dado ao conceito de método é limitante e, segundo Edgar Morin (2000, p. 335), resulta da degradação de seu significado original, sofrido no seio da ciência clássica. Conforme afirma o autor, "na perspectiva clássica o método não é mais que um corpus de receitas, de aplicação quase mecânica, que visa a excluir todo o sujeito de seu exercício. O método degrada-se em técnica porque a teoria se tornou um programa".

Diante da infinidade de variáveis do processo de realização audiovisual, sabe-se que um método de trabalho entendido como uma "receita de bolo", mesmo se aplicada segundo um princípio rigoroso de controle dos diversos procedimentos, é insuficiente para a intrincada realidade dos processos de produção cinematográfica.

Para responder às demandas da realização audiovisual, entende-se que método é algo mais dinâmico e deve ser compreendido a partir do conceito apresentado por Morin (2000, p. 335 ) no contexto da teoria da complexidade, na qual

[...] uma teoria não é o conhecimento; ela permite o conhecimento. Uma teoria não é uma chegada; é a possibilidade de tratar um problema. Em outras palavras uma teoria só realiza seu papel cognitivo, só ganha vida com o pleno emprego da atividade mental do sujeito. É essa intervenção do sujeito que dá ao termo método seu papel indispensável.

Nesse contexto teórico, método e teoria complementam-se, "método é atividade pensante e consciente do sujeito" que reorganiza e reconstrói o próprio conhecimento (MORIN, 2000, p. 339).

Assim, entende-se que o trabalho do técnico de som direto na realização de uma produção específica pressupõe opções de "estratégia, iniciativa, invenção e arte" que se somam a uma base comum, historicamente desenvolvida e reiteradamente aplicada, conformando um método em contínua reconstrução. 
No próximo tópico serão apresentadas as atividades fundamentais que constituem o método de trabalho do técnico de som direto, tomando como referência a realidade da produção cinematográfica ficcional brasileira.

\subsection{MÉTODO DE TRABALHO}

A denominação do profissional do som direto varia conforme o país analisado. Nos Estados Unidos, esses profissionais são chamados de "production sound mixer" ou "sound recordist”; na França, de "ingénieur du son”; nos países de língua espanhola, de "sonidistas". Independentemente da nacionalidade e a despeito de diferenças orçamentárias dos filmes nos quais trabalham, esses profissionais empregam estratégias comuns, utilizando equipamentos similares e lidando com problemas semelhantes no cumprimento das atividades de captar e registrar o som das falas e demais sons produzidos pela ação dos atores ou objetos envolvidos na mise-en-scène. Na equipe de realização audiovisual, eles são os responsáveis por zelar pela qualidade do registro sonoro sincrônico.

No atual momento da produção cinematográfica ficcional brasileira, o técnico de som usualmente é contratado para atuar em duas fases do processo de realização: na chamada "pré-produção" e na filmagem propriamente dita. Na pré-produção, o técnico de som direto se incorpora à equipe para participar do processo de preparação da filmagem. Durante essa etapa, serão definidas detalhadamente as estratégias de trabalho que serão aplicadas posteriormente. Durante a filmagem, no set, o técnico de som direto é o responsável por executar os procedimentos da rotina de captação e registro do som sincrônico.

\subsubsection{Pré-produção: a definição das estratégias}

Durante a pré-produção, são feitas sessões de leitura do roteiro com a participação dos responsáveis pelas diversas áreas técnicas que constituem a equipe de realização (diretor, diretor de arte, assistente de direção, fotógrafo, técnico de som direto, diretor de produção, produtor de set, figurinista, entre outros). Essa análise técnica possibilita que cada profissional defina as necessidades, em suas respectivas áreas, a partir das indicações contidas no roteiro. 
Nesse momento, o técnico de som direto detalha todas as demandas necessárias e define as estratégias de captação, considerando os equipamentos, a equipe e os materiais necessários.

O trabalho da pré-produção é decisivo para o sucesso da etapa seguinte, pois é nesse momento que se define: quais as cenas com som direto; se as cenas são simples, constituídas apenas por diálogos e ambientes; se são cenas mais complexas, requerendo equipamentos específicos, como nas apresentações musicais ou coreografias; se são cenas em situações especiais de captação, como o interior de veículos em movimento. A leitura detalhada do roteiro permite o planejamento das estratégias de captação e a definição do número e do tipo de microfones, escolhidos em função do número de personagens que interagem e da mise-enscène pretendida, que serão necessários em cada cena.

Nessa fase, devem ser precisamente indicados os pontos de intersecção com as outras áreas técnicas da realização que podem interferir no trabalho do som direto e devem ser buscadas alternativas conjuntas para a criação de condições adequadas para a captação de som: a) com a fotografia: discussão do tipo de iluminação pretendida considerando a utilização de microfones aéreos operados pelo boom; b) com a direção de arte e a cenografia: atenção na construção dos cenários e na escolha dos objetos cenográficos (móveis e utensílios gerais), que não produzam ruídos indesejados durante as cenas e auxiliem na absorção do som; c) com a produção de set: apontamento das possíveis necessidades de controle do tráfego de veículos e a supressão de fontes sonoras indesejáveis, no caso de filmagens externas, locações, ou mesmo em estúdios sem isolamento acústico; d) com o departamento do figurino: apontamento da necessidade de roupas e adereços que não produzam ruídos e que possibilitem a ocultação dos microfones de lapela sem fio.

Um dos aspectos mais importantes dessa etapa é a compreensão da proposta estética e do estilo da direção que serão materializados nas ações concretas durante as filmagens (enquadramentos, movimentos de câmera, mise-en-scène, estilo de atuação, entre tantas outras variáveis à disposição da direção). O técnico de som deve elaborar estratégias que corroborem as premissas da direção e que permitam obter registros sonoros tecnicamente adequados e esteticamente coerentes com a proposta de realização. É também função do profissional do som o alerta ao diretor/produtor executivo sobre as proposições de direção que possam comprometer a captação de som direto com qualidade técnica para integrar a trilha sonora final.

$\mathrm{Na}$ fase de pré-produção, além da análise técnica, o técnico de som direto é responsável por avaliar as condições acústicas das locações (casas, apartamentos, escritórios e 
galpões) potencialmente interessantes para a demanda do roteiro e para a proposta de direção. São dois os parâmetros empregados nesta avaliação: o nível de ruído ambiente e o grau de reverberação. O baixo nível de ruído ambiente e um pequeno grau de reverberação são decisivos na escolha dos locais de filmagem. Nessa etapa do trabalho, cabe ao profissional do som apontar e solicitar soluções para melhoria das condições acústicas das locações. Se o profissional entender que as condições acústicas não apresentam os requisitos mínimos necessários para o desenvolvimento do trabalho, deve vetá-las. Essa última situação é muito delicada para o profissional do som, pois se uma locação atende às demandas de todas as outras áreas, existe uma pressão, às vezes pouco sutil, para que seja aprovada também pelo técnico de som, mesmo que não atenda completamente às suas necessidades.

A última etapa conjunta da fase de preparação é constituída pelas visitas técnicas ${ }^{65}$ a cada uma das locações previamente escolhidas. Essas visitas ocorrem pouco tempo antes do início das filmagens. Em cada tec scout o diretor apresenta a proposta de decupagem ${ }^{66}$ das cenas da locação. A decupagem apresentada na visita técnica é uma informação preciosa, pois é a referência mais palpável, desde o início da preparação, de como o diretor pretende materializar a cena descrita no roteiro, permitindo que cada departamento defina detalhadamente as necessidades para a concretização da proposta de direção. A partir da decupagem, o técnico de som direto revê as estratégias de captação elaboradas durante a análise técnica e detalha os procedimentos para a realização da cena. Ainda durante as visitas, o técnico de som discrimina as intervenções necessárias para criar as condições acústicas adequadas para a prática do som direto e solicita a execução das tarefas aos departamentos responsáveis.

As intervenções acústicas visam aumentar o isolamento sonoro e a diminuição da reverberação. Entre os procedimentos para a melhoria das condições acústicas, pode-se destacar: colocação de vidros antirruídos; fechamento de vãos para o exterior por meio de construção de paredes de alvenaria; manutenção de portas e janelas; colocação de borrachas

\footnotetext{
${ }^{65}$ Visita técnica se origina de technical scout ou tec scout, termo usado na realização audiovisual norte-americana para designar as visitas, organizadas pela produção, com todos os chefes de equipe às locações aprovadas. Nessas visitas, cada departamento detalha as necessidades operacionais e materiais para a filmagem. Em geral participam das visitas o diretor, o assistente de direção, o diretor de arte, o fotógrafo, o chefe de elétrica, o eletricista, o maquinista, o diretor de produção, o produtor de set e o técnico de som direto. No cotidiano da produção brasileira, o termo é normalmente utilizado em inglês.

${ }^{66}$ O termo "decupagem" é utilizado com o sentido de processo de decomposição da ação em planos que constituirão as unidades de montagem para a construção de uma sequência.
} 
de vedação em janelas pré-existentes; construção de grids $^{67}$ para a sustentação de mantas acusticamente absorventes. É durante o tec scout que o técnico de som, o gaffer $^{68}$ e o produtor de set, definem conjuntamente a posição e a distância do caminhão gerador para minimizar sua presença sonora durante a filmagem. Também é durante o tec scout que é solicitada a atenção dos departamentos de "maquinária" 69 e eletricidade em relação ao posicionamento dos reatores eletrônicos usados nos equipamentos de luz e em relação aos pontos de entrada dos cabos de energia para que não seja comprometido o isolamento acústico da locação. As decisões tomadas nas visitas técnicas são definitivas; o que não tiver sido previsto pelo técnico de som pode ser desastroso durante a filmagem. Da mesma forma, as orientações de decupagem assumidas pela direção devem ser mantidas para que a preparação executada por cada departamento tenha validade.

\subsubsection{Filmagem: a captação e o registro do som direto}

As estratégias de captação previstas na pré-produção serão efetivadas durante a filmagem. Nessa etapa, a equipe de som é constituída pelo técnico de som, um ou dois microfonistas e um assistente. Como chefe de equipe, o técnico de som responde perante a produção executiva pela qualidade do trabalho e pela eficiência de sua equipe. No set, as atribuições dos integrantes da equipe seguem um esquema definido, o qual pode ser resumido da seguinte forma: a) antes da tomada da cena, o técnico orienta sua equipe na execução da estratégia de captação e durante a tomada; monitora o sinal, garantindo o nível correto de gravação e avaliando a qualidade técnica e estética dos sons registrados; b) o microfonista auxilia o técnico na implementação da estratégia de captação, quando a opção for o uso do direcional suspenso pelo boom, é ele quem garante o posicionamento correto do microfone em relação à fonte sonora durante a tomada da cena; c) o assistente de som é responsável pela montagem/desmontagem e a organização dos equipamentos no set.

\footnotetext{
${ }^{67}$ Grid é o termo utilizado para designar uma estrutura quadriculada suspensa acima do cenário que permite a fixação de refletores e outros dispositivos necessários para a realização cinematográfica.

${ }^{68}$ Gaffer é o eletricista chefe, responsável pela coordenação das equipes de eletricistas e dos maquinistas. É o profissional responsável pela execução da iluminação das cenas.

${ }^{69}$ A "maquinária" é o departamento responsável pela instalação das estruturas para a fixação dos refletores de luz e pela operação dos equipamentos que movimentam a câmera, tais como, dollys e gruas.
} 
As estratégias de captação de som nas realizações ficcionais podem ser ordenadas segundo quatro arranjos básicos:

- Microfone direcional sustentado pelo boom por cima da cabeça dos atores, posicionado sobre a linha superior do quadro;

- Microfone direcional sustentado pelo boom abaixo da cabeça dos atores, apontando para cima, posicionado sob a linha inferior do quadro;

- Microfone direcional fixo ("plantado"), cobrindo uma área de captação no interior do cenário;

- Microfone de lapela, preso ao corpo dos atores.

O uso de microfone direcional se apresenta como a opção preferencial dos profissionais do som direto, especialmente em função da resposta obtida em relação à captação da voz humana que soa "mais natural" quando comparada à captação realizada com microfones de lapela. Essa representação "mais natural" decorre das características de captação desses microfones e são percebidas principalmente em dois aspectos: na fidelidade ao timbre original da voz e na preservação das características acústicas do espaço no qual a voz é captada. Os microfones direcionais captam, além do sinal direto da voz que chega até ele, o sinal do campo reverberante, resultado das reflexões das ondas sonoras da voz, do espaço no qual a cena se desenvolve. Essa característica dá ao som da voz captada com os direcionais a impressão de pertencimento ao espaço representado na imagem. Essa adequação entre a espacialidade do som e a imagem é denominada por Tomlinson Holman como "perspectiva do microfone". Segundo o autor, essa "perspectiva é a correspondência entre som gravado e as características da imagem, em particular a equivalência dos sons refletidos e das propriedades da reverberação em relação ao que vemos" (HOLMAN, 2002, p. 87, tradução nossa).

Entre as estratégias de captação com o uso de direcionais, o emprego do microfone no boom acima da cabeça dos atores é a preferida pelos técnicos de som direto, pois resulta numa sonoridade mais próxima daquela percebida quando se ouve uma pessoa falando; portanto, é mais natural. Segundo Tomlinson Holman, "nenhum sistema é capaz de 'capturar' o som de fontes sonoras reais em sua total complexidade espacial” (HOLMAN, 2002, p. 13, tradução 
nossa). Assim, resta ao técnico de som escolher uma posição de microfone que permita uma captação que, ao menos, "represente" a fonte sonora e garanta que ela seja reconhecida. O complexo padrão de radiação da voz no ar determina que, mesmo mantendo uma distância constante em relação à fonte, a voz captada pelo microfone soará diferente, caso ocorra movimento da fonte em relação ao microfone. Assim, na prática, de acordo com Holman (2002, p.13, tradução nossa), a posição do microfone "preferida na maioria dos casos é sobre a cabeça do ator, em frente à boca, num ângulo de $45^{\circ} \mathrm{em}$ relação ao horizonte, na posição de boom mike". Uma precisa operação do boom garante que a posição do microfone seja uniforme em relação à fonte, mesmo em situações de grande movimentação, permitindo a captação da voz sem variações de timbre. A execução dessa estratégia depende da competência do microfonista que, durante a tomada da cena, carrega a qualidade do som captado literalmente em suas mãos. David Lewis Yewdall aponta as habilidades e o conhecimento desses profissionais para a execução da complexa tarefa de posicionar corretamente o microfone usando o boom. Segundo Lewis:

The boom operator is an incredibly important position: if he or she does not get the microphone into the right position at the proper moment, the actor's voice is off-axis and sounds off-mike. There is no such postproduction "plug-in" to process off-mike dialog and correct it. Off-mike is off-mike! The boom operator must be strong and agile, as well as attentive and observant. He or she must know the exact positions of invisible boundaries below which the microphone must not dip down into the camera view. The boom operator must also memorize light throws and angles so as not to allow the shadow of the microphone to be seen on any surface of the area being photographed (YEWDALL, 2007, p. 58).

Nessa estratégia, o sucesso da captação depende do desempenho do operador de boom que, nas realizações cinematográficas ficcionais, decora o texto da cena e as respectivas posições dos atores, ponto a ponto, para obter o melhor resultado de captação. Segundo Holman (2002, p. 90, tradução nossa), a operação de microfone (booming) pode incluir “caminhar acompanhando o deslocamento dos atores, movimentar lateralmente o 'braço' do boom entre dois atores, fazer a rotação do microfone na ponta do boom", buscando o melhor posicionamento do microfone. Esses procedimentos devem ser precisamente realizados, conforme o autor, mantendo o "microfone fora de quadro e as sombras do microfone ou do boom em posições do cenário que não sejam fotografadas". Além disso, a movimentação do microfonista deve ser silenciosa e a manipulação do boom suave para não provocar ruídos no microfone. 
O uso do direcional suspenso pelo boom garante a correção da posição do microfone em relação à fonte emissora. Em uma cena com movimentação de atores, a manutenção do microfone na posição mais adequada para a captação é garantida pela ação precisa do microfonista, que dinamicamente reposiciona o microfone por meio de movimentos sutis, mantendo o eixo do microfone sempre voltado para a boca dos atores. Essa estratégia possibilita a captação da voz com intensidade e presença constante desde que o enquadramento se mantenha nas mesmas proporções ao longo da cena.

Se as condições no set impedem a utilização do boom acima da cabeça dos atores, tanto pela falta de espaço para o posicionamento do boom acima da linha superior do quadro quanto pela existência de luzes que projetem sombras visíveis em quadro, a opção do técnico de som é posicionar o boom abaixo da linha inferior do quadro, apontando-o para cima em direção à fonte sonora. Essa opção tem duas desvantagens evidentes em relação à primeira estratégia, são elas: com o microfone mais próximo do peito, são enfatizadas frequências médias e baixas e eventualmente perda dos agudos da voz humana, as quais modificam o timbre, tornando-o mais cavo e menos brilhante; a operação do boom por baixo é sempre mais difícil em função da existência de objetos do cenário ou de outros atores em cena, os quais obstruem a livre movimentação do boom, comprometendo o posicionamento do microfone. Em função das circunstâncias da filmagem, o técnico de som direto deve avaliar se o prejuízo causado pela mudança no timbre da voz é compensado pela melhoria da relação entre o sinal direto e o ruído de fundo, quando optar por essa estratégia. Uma situação que exemplifica essa condição é a captação de diálogos com atores caminhando num piso coberto por cascalho. Os microfones direcionais são muito sensíveis a esse tipo de ruído e normalmente intensificam sua própria presença, gerando um registro de voz fortemente contaminado pelo ruído de fundo. Nessa condição, se o enquadramento da cena permitir, a estratégia de captação com o direcional apontado para cima pode ser uma opção para tornar o diálogo mais claro e inteligível.

Quando as condições do set impedem a opção pelo boom, em função de um plano geral muito aberto ou, numa situação oposta, num espaço muito reduzido que impossibilita a operação do boom, pode-se optar pela colocação de um microfone fixo ("plantado") que não seja visível em quadro e que faça a cobertura para a captação do som de uma determinada área da cena. Essa estratégia não permite a realização de ajustes na posição do microfone durante a cena e o técnico de som fica dependente do posicionamento dos atores para a captação das falas. Em uma proposta de realização convencional, com cenas rigidamente 
"marcadas", o ator coloca-se nessas "marcas", favorecendo as necessidades da captação da imagem e do som. No entanto, produções que optam por cenas improvisadas diminuem a viabilidade dessa estratégia. O uso de um microfone "plantado" acrescenta uma variável ao processo de captação (o posicionamento dos atores), sobre a qual o técnico de som direto não exerce real controle.

Quando as condições de filmagem inviabilizam a captação do som utilizando o microfone direcional, o técnico de som deve lançar mão dos microfones de "lapela", presos ao corpo dos atores. Esses pequenos microfones são, na maioria das vezes, colocados sob as roupas dos atores, enviando o sinal de áudio para o gravador através de um sistema de transmissão via rádio; por isso, são comumente chamados de "microfones sem fio". Planos gerais que impedem a colocação do boom próximo à fonte sonora, situações de filmagem ruidosas ou com muita reverberação, podem ser resolvidas com o emprego dessa estratégia. A vantagem dessa opção é a proximidade do microfone em relação à fonte sonora que permite, mesmo em situações acústicas adversas, a captação da voz com forte presença do sinal direto em relação ao ruído de fundo, independentemente das mudanças de enquadramento. A voz captada por esses microfones, em geral, tem sonoridade de menor qualidade quando comparada à sonoridade obtida com os microfones direcionais.

No entanto, a principal crítica a esses microfones está relacionada à sua representação sonora. Tomlinson Holman (2002, p. 91, tradução nossa) considera que "essa é a última opção de captação, pois apesar de o ator poder ser ouvido, exceto em casos de muito ruído de fundo, não existe absolutamente nada de natural em relação à perspectiva sonora reproduzida por este arranjo". Com a captação feita por lapelas, as vozes mantêm-se sempre num primeiro plano independente da movimentação e da posição do ator em quadro, resultando numa voz “desencarnada da imagem". Em cada ator, com linha de diálogo em cena, deve ser instalado um microfone de lapela, pois, em geral, os microfones de lapela só captam a voz do ator no qual está instalado.

As principais dificuldades encontradas pelo técnico de som, em relação ao uso dos microfones de lapela, são as seguintes:

- A necessidade de esconder o microfone, às vezes sob várias camadas de roupas, modifica o timbre da voz captada com a perda de frequências agudas, tornando-a "apagada" ou sem "brilho". 
- Os atritos da roupa próximos ao microfone, ou diretamente sobre a cápsula do lapela, são captados como ruídos extremamente fortes, narrativamente injustificáveis, que comprometem a captação da voz. O uso de roupas adequadas e a correta colocação do microfone são fundamentais para evitar esse problema. $\mathrm{O}$ ruído provocado pelo atrito das roupas sobre a cápsula do microfone é o maior temor do técnico de som ao optar por essa estratégia. Não existe um procedimento "mágico" que solucione esse problema. É uma variável aleatória sobre a qual o técnico exerce pouco controle. Cenas com muita movimentação dos atores potencializam esse problema.

- O movimento de um ator ou o contato físico entre os atores durante a tomada da cena pode gerar choques mecânicos, que serão convertidos e intensos ruídos, contra a cápsula dos microfones, colocadas normalmente na altura do tórax dos atores. É comum a ocorrência dessa situação durante a cena sem que nunca tenham acontecido durante os ensaios. No "calor da ação" esses eventos são de difícil controle e, quando ocorrem simultaneamente com a fala, inviabilizam o som direto captado.

- O tipo de cápsula do microfone de lapela e a proximidade em relação à fonte podem gerar uma captação com sinal distorcido ou com variação de timbre. Se num momento da cena, o ator projetar muito a voz, a intensa pressão sonora pode provocar a saturação do sinal elétrico na cápsula e gerar a distorção do som captado, desfigurando completamente a voz registrada. A impossibilidade de afastamento da cápsula durante a cena, deixa o técnico sem controle sobre essa situação. A movimentação da cabeça do ator gera mudanças no timbre da voz captada se a cápsula do microfone de lapela estiver colocada no centro do tórax. Ao movimentar a cabeça lateralmente durante a fala, a fonte sonora se aproxima e se afasta do microfone, gerando perceptíveis mudanças no timbre e na intensidade da voz captada. O problema será ainda maior se a movimentação de cabeça for para cima e para baixo, nessa situação, com a cabeça posicionada para cima, a voz fica "fora do microfone" (off-mike); com a cabeça posicionada para baixo, a fonte sonora fica colocada muito próxima da cápsula do microfone, enfatizando as baixas frequências e alterando fortemente o timbre da voz.

- Os sistemas de radiotransmissão, que enviam o sinal de áudio do microfone de lapela à plataforma de gravação, são potenciais fontes de problemas na qualidade 
do som captado, entre os mais comuns podem ocorrer: perda momentânea do sinal de transmissão (dropout); interferência com outras fontes de radiofrequência (telefones celulares, sistemas de comunicação usados pela equipe); demasiada compressão no sinal de áudio para a transmissão via rádio. A qualidade dos sistemas de transmissão é diretamente proporcional ao custo de aquisição.

A estratégia de captação com microfones de lapela via rádio é normalmente carregada de tantos inconvenientes que a sua adoção é feita quando não resta outra opção. Nessas circunstâncias, o técnico de som abre mão das sutilezas de uma representação sonora com maior adequação acústica, possibilitada pelos microfones direcionais, a favor de um registro sonoro "limpo" e inteligível, propiciado pelos microfones de lapela. Cenas improvisadas, com vários atores contracenando, são situações nas quais os microfones sem fio se tornam ferramentas de trabalho preciosas para o técnico de som direto. Dependendo da complexidade da cena, o técnico de som pode combinar livremente cada uma das estratégias descritas para viabilizar a captação do som direto.

A nova tecnologia de gravadores digitais portáteis multipista tem fomentado a tendência do uso dos microfones de lapela concomitantemente ao boom como segurança ou reforço do registro sonoro captado pelo microfone direcional. A tecnologia multipista permite a captação de várias fontes em canais separados, gerando registros sonoros independentes que podem ser usados complementarmente na pós-produção. Registros independentes de várias fontes simultâneas modificam um procedimento fundamental no método de trabalho do técnico de som direto: a monitoração da qualidade do registro sonoro. Como vimos no capítulo anterior, na prática usual historicamente estabelecida do som direto, o registro sonoro era feito em uma ou, no máximo, duas pistas. Mesmo operando com vários microfones simultâneos, o técnico fazia a mixagem das fontes e a resultante sonora era monitorada precisamente durante a gravação. Na captação em multipista, o técnico de som precisa desdobrar-se em "multiorelhas" para avaliar precisamente as várias pistas registradas simultaneamente. É uma mudança paradigmática na prática de trabalho do som direto. A monitoração de vários canais independentes é um procedimento ainda não padronizado pelos técnicos de som. Diferentes soluções são aplicadas, indicando uma reestruturação do método de trabalho. Alguns técnicos optam por ouvir os microfones de lapela enquanto o microfonista monitora o direcional que está operando; outros trafegam pelas várias pistas durante a 
gravação, buscam ouvir um trecho de fala de cada microfone e criam um ciclo de monitoração, muitas vezes, pouco preciso.

O potencial trazido pelos gravadores digitais portáteis multipista estimulou o surgimento de propostas de edição que tendem a priorizar o uso dos microfones de lapela em detrimento dos microfones direcionais. Em linhas gerais, essa tendência defende que a sonoridade mais "limpa", obtida pela captação com os microfones de lapela, permite maior liberdade no processo de edição, reduzindo os inconvenientes ruídos e "espacialidades" que acompanham as captações realizadas com os direcionais. A reconhecida falta de espacialidade na voz captada pelos microfones de lapela é, nessa proposta de edição, compensada por meio da utilização de processadores de som que, durante a mixagem, acrescentam a reverberação necessária na voz para a criação de uma espacialização acústica coerente com a imagem.

Foge do interesse desse trabalho discutir a pertinência técnica ou estética dessa proposta de edição, o que interessa a este trabalho é discutir como essa opção interfere no trabalho de captação de som direto. A opção por captar o som direto de um projeto cinematográfico de longa-metragem, utilizando essencialmente microfones de lapela, limita o espaço de atuação do profissional do som, restringindo-o a uma dimensão ainda mais técnica. A participação criativa do profissional do som se dá a partir da escolha das diferentes estratégias de captação, do emprego de diferentes microfones direcionais (com "colorações" próprias) e das inúmeras intervenções acústicas nos espaços de filmagem que imprimem no som direto uma textura particular, que resulta da sensibilidade do profissional do som. A restrição dessa atuação reduz o potencial criativo e normatiza a rotina de trabalho do técnico de som.

\subsubsection{A rotina de trabalho do som direto no set}

No set de uma realização cinematográfica ficcional, a captação do som direto é estruturada a partir de um conjunto de procedimentos regulares que visam à qualidade do registro do áudio sincrônico. Esses procedimentos são dinamicamente empregados pelos membros da equipe de som, constituindo-se em uma rotina de trabalho. As diferentes realidades de produção geram adaptações dessa rotina, porém não a modificam substancialmente. Os procedimentos de captação estão em consonância com a preparação realizada durante a pré-produção, que envolve, entre outras decisões: a escolha e o tratamento 
acústico das locações; a definição das estratégias e a configuração do aparato técnico; a infraestrutura de produção.

Serão sistematizados, a seguir, os principais procedimentos que caracterizam a rotina de trabalho da equipe de som direto.

- Montagem, checagem e configuração dos equipamentos. No início do dia de trabalho é realizada a "montagem dos equipamentos" (cabeamento de todos os dispositivos que serão utilizados), quando é testado o funcionamento de cada um. O técnico de som: a) gera sinais de referência a partir de geradores de frequência de som do próprio sistema; b) testa a qualidade do áudio que chega aos fones de ouvido; c) ouve a resposta de cada um dos microfones que serão empregados na cena, avaliando a fidelidade da captação; d) monitora, atentamente, a existência de algum ruído elétrico (hum) indesejável que possa trafegar no sistema e busca eliminá-lo. Empregando a tecnologia atual para o registro sonoro (gravadores digitais multipista), o técnico de som faz a checagem da configuração dos parâmetros para a digitalização do som; organiza o roteamento das entradas de sinal para os canais de gravação; configura os dispositivos de contagem de tempo e envia o sinal de time code para a câmera.

- Posicionamento do equipamento. A base de trabalho do técnico de som direto é montada em local estratégico que permite a visualização da cena ou, no mínimo, o acesso rápido ao set. $\mathrm{O}$ posicionamento do equipamento também considera a passagem dos cabos para o microfonista e para o vídeo assist $t^{70}$ de forma prática e segura.

- Avaliação das condições acústicas do set. Antes de iniciar as tomadas de cena, o técnico de som direto faz uma varredura para localizar fontes sonoras indesejadas e organiza esforços para eliminá-las. São checados: refletores ou reatores elétricos utilizados na iluminação da cena; sistema de ar condicionado; objetos de cena ruidosos (geladeiras, computadores, mesas e cadeiras); o posicionamento do gerador de energia elétrica. Quando o set está montado em locações ou estúdios com tratamento acústico deficiente, o técnico de som avalia a

\footnotetext{
${ }^{70}$ Vídeo assist é o sistema de vídeo que registra a imagem e o som da tomada e permite ao diretor assistir a cena captada.
} 
necessidade de aprimoramento nas intervenções acústicas, tais como: a colocação de mantas de som extras em janelas e portas para reduzir os ruídos externos; a disposição de mantas de som no entorno da cena para minimizar a reverberação. O técnico de som também monitora a existência de ruídos pontuais externos que necessitem da intervenção da produção para silenciá-los.

- Controle sobre o ruído produzido pela atividade da equipe. Durante a captação dos diálogos, mesmo com uma experiente equipe de filmagem, é necessária a atenção do técnico de som direto para combater os ruídos produzidos pela atividade da equipe de realização. Um controle cuidadoso é realizado, solicitando a cooperação dos profissionais envolvidos, para evitar a presença de ruídos provenientes da operação de equipamentos como dolly e grua ou mesmo o ruído provocado pela movimentação da equipe durante a captação da uma cena com câmera na mão.

- Controle sobre o ruído produzido pelos atores em cena. Ao gravar os diálogos, o técnico de som dedica especial atenção sobre os ruídos produzidos pela ação dos atores em cena. Na busca por diálogos inteligíveis e "limpos", o técnico de som interfere na realização da cena na tentativa de minimizar a produção de ruídos que prejudiquem a clareza das "falas", tais como: as batidas de porta e a manipulação de objetos ruidosos (talheres, pratos, panelas). O técnico de som atua diretamente sobre a fonte geradora de ruídos tentando suprimi-la, por exemplo: o ruído proveniente da batida de uma porta é diminuído com a colocação de feltros autoadesivos nos batentes e com a lubrificação das dobradiças; copos e xícaras são tratados com borrachas autoadesivas ou fita dupla face de silicone; o ruído dos passos é normalmente reduzido por meio da colocação de feltros autoadesivos nas solas dos sapatos ou por intermédio da colocação de carpetes/mantas de som no caminho que será percorrido pelos atores e membros da equipe que necessitem deslocar-se durante a cena. Esse procedimento parece contraditório, pois normalmente os ruídos relacionados com a ação dos personagens serão pós-sincronizados durante a edição de som, porém, dessa forma é alcançada total independência entre as "falas" e os ruídos para o controle de nível e equalização que ocorrerão durante a mixagem. Quando os ruídos de cena são incontroláveis, o técnico de som solicita a colaboração dos atores para que o texto não seja proferido durante a ocorrência dos ruídos (como 
as batidas de porta, por exemplo). Sempre, por meio do diretor ou do assistente de direção, o técnico de som roga aos atores delicadeza e cuidado ao manipular louças, talheres e outros objetos de cena ruidosos. Em certas situações é necessário solicitar aos atores maior projeção de voz.

- Definição da estratégia de captação. A definição da estratégia de captação é feita a partir da análise das condições acústicas do set, da mise-en-scène e do enquadramento definido pela direção. A estratégia de captação prevista na préprodução é colocada em prática, adequando-se às condições objetivas encontradas no set. A implementação da opção do uso do microfone direcional operado pelo boom é feita conjuntamente pelo técnico de som e pelo microfonista, definindo, entre outros: o melhor posicionamento do operador de boom; a movimentação e a angulação do microfone; a área de cobertura e o deslocamento a ser realizado pelo operador. A necessidade de reposicionamento de peças do cenário (como lustres e móveis, por exemplo), para permitir a livre movimentação do boom durante a cena, é negociada com a direção de arte e com a direção de fotografia. A aplicação de estratégias híbridas é avaliada com o microfonista a partir dos ensaios da cena.

- Colocação dos microfones de lapela. Quando os microfones de lapela com transmissão via rádio são necessários, o técnico de som comunica a assistência de direção, que determina o momento no qual a cápsula do microfone de lapela e o radiotransmissor serão instalados no ator. A instalação deve ser feita com cuidado, evitando que a cápsula fique coberta por tecido pesado e livre do atrito das roupas sobre ela. O transmissor de radiofrequência é firmemente afixado no corpo do ator por meio de cintos elásticos, evitando que ele se movimente ou se solte durante a cena. A colocação do transmissor sob a roupa do ator deve ser feita com muito respeito para evitar constrangimentos. Quando necessário, é solicitada a ajuda da figurinista ou da camareira para realizar a colocação dos transmissores no corpo das atrizes. O técnico de som deve informar a necessidade de uso do microfone de lapela e pedir a colaboração dos atores, os quais, normalmente, sentem-se incomodados com a presença desse equipamento junto ao corpo; em particular, atrizes com figurino mais justo. Em situações como essa, é necessário encontrar soluções para acomodar o transmissor confortavelmente sob a roupa, sem prejudicar a aparência da atriz. 
- Realização de ensaios. O técnico de som direto solicita sempre a realização de ensaios antes da realização da tomada da cena. Durante o ensaio, o técnico de som avalia se a estratégia de captação escolhida é adequada. O ensaio é o único momento, antes da tomada da cena, no qual a condição de silêncio no set se aproxima daquela que existirá durante a captação. Essa condição de silêncio alcançada para o ensaio possibilita ao técnico de som avaliar, entre outras coisas: a existência de alguma fonte sonora indesejável que não tenha sido percebida antes; se a ação envolve a manipulação de objetos que produzam ruídos indesejáveis. Durante o ensaio, o microfonista conhece a movimentação dos atores em cena, o momento das falas e as correções necessárias para o posicionamento do microfone.

- Checagem do nível de ruído ambiente. Antes de "rodar" o som, após a ordem de comando dada pela assistência de direção para gravar, o técnico de som deve avaliar por alguns segundos (com o set livre do ruído da equipe de filmagem) o grau de silêncio do ambiente. O técnico de som ouve brevemente, através dos fones de ouvido, o nível de ruído do ambiente e determina se as condições são adequadas ao registro sonoro. Ele foca a atenção para qualquer ruído indesejável, tais como: carros, motos ou aeronaves em aproximação. Só após a constatação das condições adequadas, ele inicia a gravação e anuncia que “o som está rodando!”.

- Captação monofônica dos diálogos. A captação dos diálogos pelo som direto é monofônica mesmo com o emprego de múltiplos microfones e plataformas de gravação multipista. Usualmente, na captação das vozes não interessa a criação de uma representação que localize a posição da fonte sonora no espaço. Essa localização é obtida na pós-produção durante a mixagem com a panoramização dos elementos sonoros. Porém, geralmente os diálogos são mixados para serem reproduzidos pelo alto-falante posicionado no centro da tela, nas salas de exibição.

- Relato dos problemas de captação. Qualquer problema durante a captação que inviabilize a utilização do plano de som é prontamente informado à direção e devidamente anotado no relatório de som. O técnico de som busca explicar as causas do problema e propor alternativas que permitam corrigi-lo.

- Captação de "coberturas de diálogos". O técnico de som indica a necessidade da realização da captação de trechos curtos do diálogo (pick up wild lines), que 
porventura tiveram a qualidade comprometida durante a tomada da cena em função da ocorrência de algum ruído inconveniente (batida de uma porta, buzina de um carro). As coberturas de som podem ser usadas na edição, substituindo os trechos de diálogo dos planos com problemas. A pertinência desse procedimento será exemplifica na descrição dos procedimentos de captação de som direto da sequência 27 do filme Contra todos, no próximo capítulo.

- Captação do ruído de fundo. Após a tomada da cena com diálogos, o técnico de som grava o ruído de fundo (room tones ou presence fill) do local onde a cena foi captada, utilizando o mesmo microfone empregado na tomada. Os room tones são fundamentais para o processo de edição dos diálogos, fornecendo elementos sonoros para a ocultação dos cortes entre os planos de som editados ou para preencher trechos de diálogo que porventura venham a ser dublados. Dependendo das condições de filmagem, o técnico de som pode realizar a captação do som ambiente, estereofonicamente, para prover a pós-produção com matéria-prima para a construção das paisagens sonoras que acompanham os diálogos e os demais elementos na constituição da trilha sonora finalizada.

- Captação de ruídos particulares. O técnico de som indica a necessidade da captação dos ruídos de objetos ou de máquinas pertencentes à cena, os quais possam ter interesse narrativo ou dramático. No set, o registro à parte de ruídos particulares proporciona, à edição de som, elementos sonoros com timbre genuíno e espacialidade coerente com a das vozes captadas pelo som direto; fornece matéria-prima que enriquece as possibilidades de articulação entre som e imagem estabelecida pela montagem. Na gravação do ruído captado no set fica impressa a indicação de pertencimento ao espaço do qual se origina. Além do valor estético, esse procedimento pode resultar em grande economia no processo de edição de som, porém a sua realização é dependente de disponibilidade de tempo durante a filmagem.

- Confecção do relatório de som. Durante as tomadas de cena, o técnico de som direto registra em boletins impressos - com diagramação adequada ao suporte de gravação utilizado -, as informações sobre o processo de captação, as quais serão posteriormente usadas para orientar os profissionais da montagem e da edição de som. Nos "boletins de som”, como é possível ver na Figura 3, são indicados, entre outros: a configuração dos parâmetros de digitalização do som; a plataforma 
de gravação utilizada; as sequências, os planos, as tomadas realizadas e os respectivos microfones utilizados; o roteamento empregado nos gravadores multipista; a realização de coberturas, gravações de ambientes ou ruídos; todas as observações relevantes sobre a qualidade dos registros sonoros. Os "boletins de som” são os mapas de gravação que trazem as principais informações sobre o som captado.

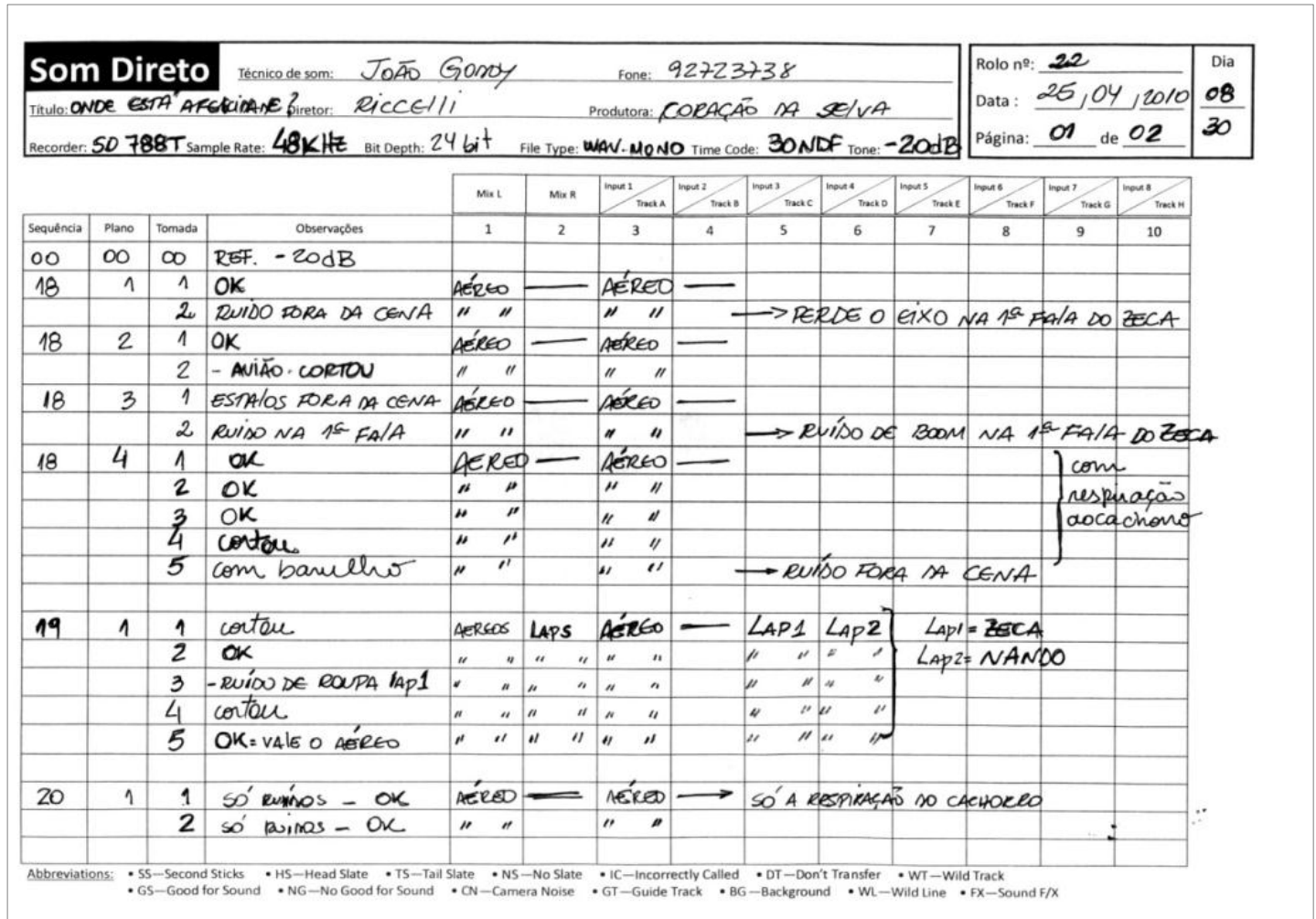

Figura 3 - Boletim de som direto diagramado para captação com plataforma multipista.

\subsubsection{A monitoração do som direto}

Durante a tomada da cena, a principal atividade do técnico de som é avaliar a qualidade do registro sonoro. A qualidade do som direto é caracterizada pela fidelidade ao fenômeno acústico que representa, pela inteligibilidade da voz e pelo grau de editabilidade que possui. A qualidade do som direto, determinada pelo código de representação do cinema narrativo, é checada dinamicamente pelo técnico de som durante a tomada da cena. Após finalizar a tomada, o técnico pode solicitar a conferência do material gravado, no entanto, o ritmo intenso do set impõe que a avaliação da gravação seja feita durante o processo de 
captação. O julgamento deve ser certeiro, os problemas com a captação precisam ser explicitados claramente para a direção, assim como as alternativas para resolvê-los. Esse é o momento crucial do trabalho de captação, o qual exige certeza e determinação do profissional do som direto.

Mesmo dispondo de indicadores visuais para o controle da intensidade do sinal que trafega no sistema captação-gravação, tais como VU ou Peak Meter, o principal equipamento utilizado para monitorar a qualidade da captação é o fone de ouvido. Essa ferramenta disponibiliza a resposta acústica do áudio que é gravado, fornecendo os dados para que a sensibilidade auditiva do técnico julgue a adequação do registro sonoro. O fone de ouvido é um equipamento fundamental à percepção do técnico; ele deve oferecer uma resposta plana ${ }^{71}$ ao longo do espectro de frequências da audição humana ${ }^{72}$ e garantir forte isolamento acústico do mundo circundante. Além dessas características técnicas fundamentais, a "personalidade" sonora do fone deve ser familiar ao técnico, pois é a partir do estímulo acústico fornecido por esse equipamento que o profissional do som avalia todo o sistema de captação/registro e julga a fidelidade do áudio em relação à fonte sonora original.

\subsubsection{As relações no set}

A obtenção de condições adequadas para captação de som no set está na dependência do conjunto de ações tomadas ao longo da etapa de pré-produção. As orientações do técnico de som, na escolha das locações, nas intervenções acústicas determinadas, na construção dos cenários, na escolha de figurinos adequados, estimulam a atenção e organizam os esforços de todas as áreas técnicas em relação às demandas do som direto. No entanto, durante a filmagem, as relações de trabalho estabelecidas no set são fundamentais para conquistar a cumplicidade e o apoio da equipe técnica para as necessidades do som direto.

A tendência do som direto é a de ser tratado como órfão no set. O resultado da predominância da imagem sobre as atividades da equipe de filmagem obriga o técnico de som a desenvolver estratégias de trabalho que garantam as condições para a captação sem colidir com as necessidades da fotografia e da direção de arte. Para não reforçar o estigma de

\footnotetext{
${ }^{71}$ Resposta plana é a característica de um sistema de áudio em captar ou reproduzir um sinal sem alterar a intensidade das frequências que o compõe.

${ }^{72}$ Espectro de audição é o intervalo de frequências, audíveis para os seres humanos, que se estende de 20 a 20.000 Hertz.
} 
"estorvo da filmagem", a equipe de som direto deve antever situações problemáticas e tentar resolvê-las antes que o set esteja pronto para filmar. Buscar silenciar fontes sonoras no momento que o diretor vai gravar é "mortal" para as relações entre o técnico de som e a direção. Assim como solicitar a mudança de posição do caminhão gerador, depois que todos os cabos de força tiverem sido estendidos, cria uma situação de intenso atrito com a equipe responsável. A presença do técnico de som e do microfonista no set durante a preparação para a tomada da cena é uma maneira de demonstrar a disponibilidade para o trabalho e de orientar os demais técnicos sobre as necessidades da captação de som. Assim, acompanhar o posicionamento dos refletores de luz no set, indicando a necessidade de espaço para operação do boom e, logo que os refletores são acesos, identificar os equipamentos causadores de ruídos e buscar uma solução para o problema são procedimentos de set que conquistam a colaboração da equipe técnica para as necessidades do som.

A equipe de som acompanha a marcação da cena, indicando ao diretor e ao fotógrafo as demandas do som direto para a realização da tomada e buscando soluções negociadas que atendam às necessidades de todas as áreas. Atento aos ensaios, o técnico de som organiza as ações de reforço do tratamento acústico e identifica a existência de ruídos provocados pela movimentação dos atores ou da equipe técnica. A habilidade do técnico de som em alcançar o apoio das demais áreas, mantendo um ambiente agradável de trabalho, é fruto de uma concepção de trabalho, que entre outros aspectos, entende que: a atividade de realização cinematográfica é uma ação coletiva; o resultado final é mais importante que o resultado de cada uma das áreas técnicas em separado; o som direto é influenciado e depende de todas as outras áreas para a sua efetivação; a negociação é a forma mais eficiente para resolver os impasses no set.

\subsection{A OPÇÃO PELO SOM DIRETO}

Como está sendo visto ao longo deste capítulo, a clareza, a limpeza e a homogeneidade que caracterizam a qualidade do registro sonoro direto só são alcançadas com condições apropriadas de filmagem.

O profissional responsável por zelar pelo registro sonoro é o técnico de som, no entanto, a criação das condições para filmar com som direto deve ser entendida como uma atividade coletiva da equipe de realização, e não como uma "penitência" executada 
isoladamente por um único profissional. Nas produções em que a opção pelo som direto é valorizada pela direção, o compromisso da equipe de filmagem com as condições de trabalho do técnico de som é maior. A equipe se organiza na busca de bons resultados para o som e para a imagem. Nessas circunstâncias, o técnico de som é visto como um integrante da equipe técnica, o qual orienta os esforços para a criação das condições de captação, propondo soluções para os problemas e estabelecendo os limites técnicos do registro sonoro. Respeitado na função que desempenha, ele é assumido como um colaborador para o desenvolvimento do trabalho coletivo, ao contrário do entendimento comumente verificado no seio da realização audiovisual, em que o técnico de som normalmente é tratado como um obstáculo para o cumprimento do cronograma de produção e responsabilizado pelos atrasos, como se o som direto fosse um apêndice e não fizesse parte do processo de realização.

É indiscutível que filmar com som direto torna o set mais complexo e demorado, pois são mais variáveis que precisam ser satisfeitas simultaneamente. Além das necessidades da imagem, há, também, as necessidades do som; portanto, a demanda de tempo para obtenção do resultado desejado é maior. Os diretores que valorizam a opção do som direto reconhecem as vantagens estéticas e orçamentárias do direto sobre o dublado e, compreendendo as limitações técnicas da captação, estabelecem procedimentos de filmagem que possibilitam o registro sincrônico.

A seguir, serão analisados alguns procedimentos de direção que influenciam na qualidade do som direto.

\subsubsection{Sobreposição das falas}

O usual recurso de decupagem $/$ montagem $^{73}$ de uma sequência com diálogo em campo e contracampo, com a câmera assumindo "o ponto de vista de um, ora de outro dos interlocutores, fornecendo uma imagem da cena através da alternância de pontos de vista" (XAVIER, 1984, p. 26), pode gerar sérios problemas de montagem se durante as tomadas dos planos individuais ocorrer a sobreposição das falas. Na medida em que é quase impossível que os atores acavalem as falas sempre no mesmo ponto de uma tomada para outra, essas sobreposições aleatórias vão restringir os pontos de corte para a montagem da sequência. Isso quer dizer que, se num determinado plano, além da fala do ator que é visto em quadro, é

\footnotetext{
${ }^{73} \mathrm{Na}$ acepção empregada por Ismail Xavier (1984, p. 28).
} 
ouvida a voz sobreposta daquele que está fora de quadro ou de costas para a câmera. O corte para a alternância de ponto de vista deverá ocorrer de tal forma que no plano seguinte (fala do ator) que passa a ser visto, continue exatamente do mesmo ponto em que foi ouvida no plano anterior. Essa amarração criada pela sobreposição das falas dos dois atores durante a captação pode inviabilizar a montagem pela inexistência de pontos de corte. A forma convencional de direção cria a sobreposição dos diálogos durante a montagem com total liberdade para a escolha do momento de corte. Nessa opção de direção, durante a tomada da cena, o ator que está de costas para a câmera movimenta a boca sem emitir som, enquanto o ator que está enquadrado frontalmente emite sua fala. Na montagem, a sobreposição das falas é forjada com a inserção de trechos do áudio do plano do enquadramento frontal, no plano de imagem em que o ator está de costas. Com esse procedimento de direção, o técnico de som capta o som direto do ator que está em quadro sem a presença da voz daquele que está de costas ou fora de quadro.

Desde que não impeça a compreensão do texto, a sobreposição das falas durante a tomada da cena não se configura num problema para o som direto. $\mathrm{O}$ cuidado do técnico de som em alertar sobre o acavalamento das falas está relacionado com a montagem e é, em última análise, uma opção de direção. Se por necessidade de uma atuação mais natural o diretor optar pelo acavalamento das vozes, o técnico de som deve cuidar para que as falas sejam captadas com a mesma presença, independentemente de o ator estar dentro ou fora de quadro, pois, caso os atores consigam reproduzir a sobreposição do texto sempre no mesmo ponto, a montagem da sequência não será dificultada pela diferença na intensidade ou na textura das vozes.

\subsubsection{Figuração silenciosa}

Captar o diálogo dos atores principais em cenas com a presença de grande contingente de figurantes pode tornar-se um problema para o som direto. Normalmente, em cenas como essas é pressuposta a compreensão das falas e, portanto, o padrão de qualidade da captação do som direto segue o protocolo convencional: obter um diálogo nítido e o mais destacado possível do ruído de fundo. Figurantes profissionais conseguem simular conversas convincentes de forma silenciosa, o que permite ao técnico de som obter uma relação adequada entre o sinal direto e o ruído de fundo. Durante a montagem, a pós-sincronização de 
um ambiente sonoro com vozerio constante, captado durante a própria filmagem ou gravado na dublagem, permite reforçar a materialidade das ações da figuração em cena. No momento da tomada da cena, o técnico de som grava o diálogo "limpo", prestando atenção para que a potência da emissão e a intenção das vozes dos atores sejam coerentes com o nível de ruído do vozerio que existirá após a sequência montada, garantindo verossimilhança à atuação. A tendência da atuação em uma situação como essa é a gradual diminuição no volume da voz em função do baixo nível de ruído no momento da captação; no entanto, os atores devem "falar alto, acima do nível de ruído que não existe lá" (HOLMAN, 2002, p.108, tradução nossa).

Alguns diretores apontam que as ações de uma figuração silenciosa não são convincentes, provavelmente pelo baixo grau de profissionalismo da figuração empregada, e por isso optam por ações "reais", com emissão de falas que resultam na produção de intenso ruído de fundo. Sob essas condições, que decorrem da opção de direção, a qualidade do som direto será comprometida.

\subsubsection{Ações potencialmente ruidosas}

Quando o som direto é valorizado, as cenas potencialmente ruidosas são planejadas conjuntamente pelas áreas técnicas envolvidas com o objetivo de encontrar soluções que satisfaçam as suas necessidades. Cenas do cotidiano doméstico, com os personagens preparando ou realizando alguma refeição, por exemplo, são frequentes e muito problemáticas para a captação do som direto. A manipulação de utensílios de cozinha de metal e de vidro (panelas, pratos, talheres) geram intensos ruídos e são desastrosos para a captação de diálogos simultâneos. A solução para a realização de cenas como essas envolvem, entre outros procedimentos: uma decupagem adequada; a atenção dos atores para o momento exato entre a execução das ações e a emissão das falas; a escolha de objetos de cena que contribuam com a minimização dos ruídos. Com um pouco de atenção, é possível perceber o emprego desses procedimentos em diversas realizações audiovisuais. Para ilustrar essa situação, foi escolhido um trecho do filme Momento de decisão (MOMENTO, 1977) ${ }^{74}$, no qual os procedimentos para garantir a captação do som direto são facilmente percebidos.

\footnotetext{
${ }^{74}$ Momento de decisão (The turning point ) conta a história de duas bailarinas, Deedee e Emma, que seguem caminhos diferentes na vida, a primeira constitui família e a outra carreira profissional. $\mathrm{O}$
} 
Na cena, há a esposa, interpretada por Shirley MacLaine, na cozinha com uma espátula na mão preparando uma refeição. Enquanto mexe continuamente o alimento na frigideira, ela conversa com seu marido, interpretado por Tom Skerrit, que está sentado ao fundo de quadro, em frente a um balcão de madeira, servindo-se de café. O diálogo é contínuo. As ações realizadas em cena poderiam facilmente prejudicar a captação das falas se não fossem executadas considerando o som direto. Para servir-se de café, as ações do ator são cuidadosas e ocorrem nos intervalos das falas. O movimento de mexer o café com a colher é feito suavemente, e a cafeteira de vidro é colocada sobre um apoiador de tecido, estrategicamente colocado à frente do ator, que amortece o impacto sobre o balcão sem provocar nenhum ruído. A ação da esposa misturando o alimento na frigideira surpreende pelo baixo nível de ruído produzido. Isso é possível graças à leveza dos movimentos e à utilização de uma espátula de silicone que não produz ruído ao entrar em contato com o metal da frigideira. Na Foto 14, é possível ver, ao fundo de quadro, o ator colocando a cafeteira de vidro sobre o apoio de tecido. Na Foto 15, é possível ver a espátula de silicone usada para preparar o alimento.

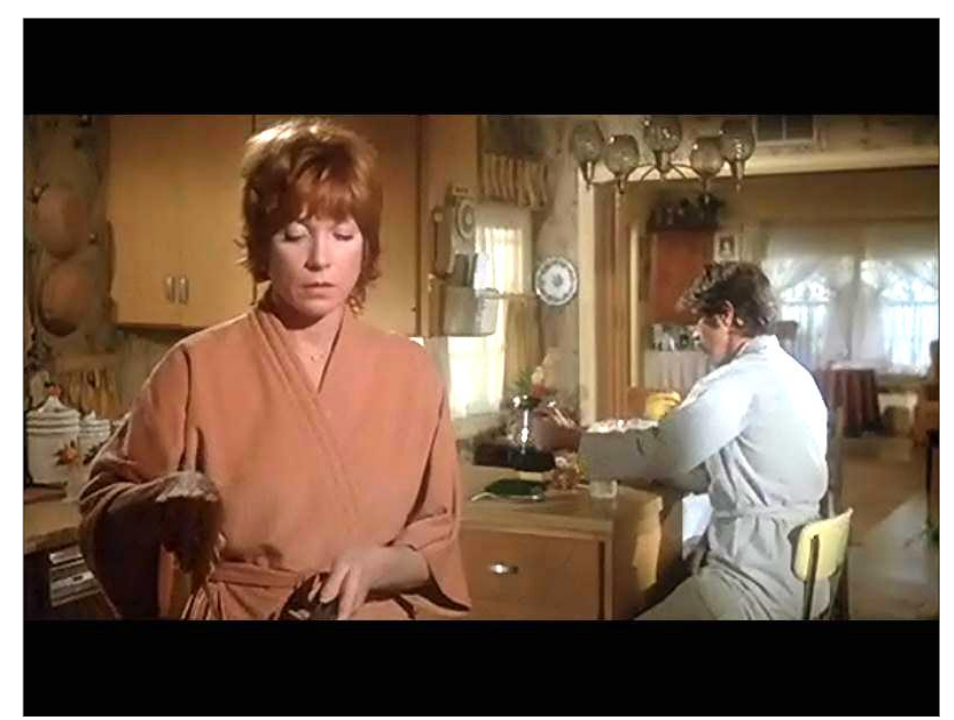

Foto 14 - Cena do filme Momento de decisão (MOMENTO, 1977).

contato entre as duas é reatado quando Emilia, a filha de Deedee, tem a chance de dançar na companhia pertencente a Emma. 


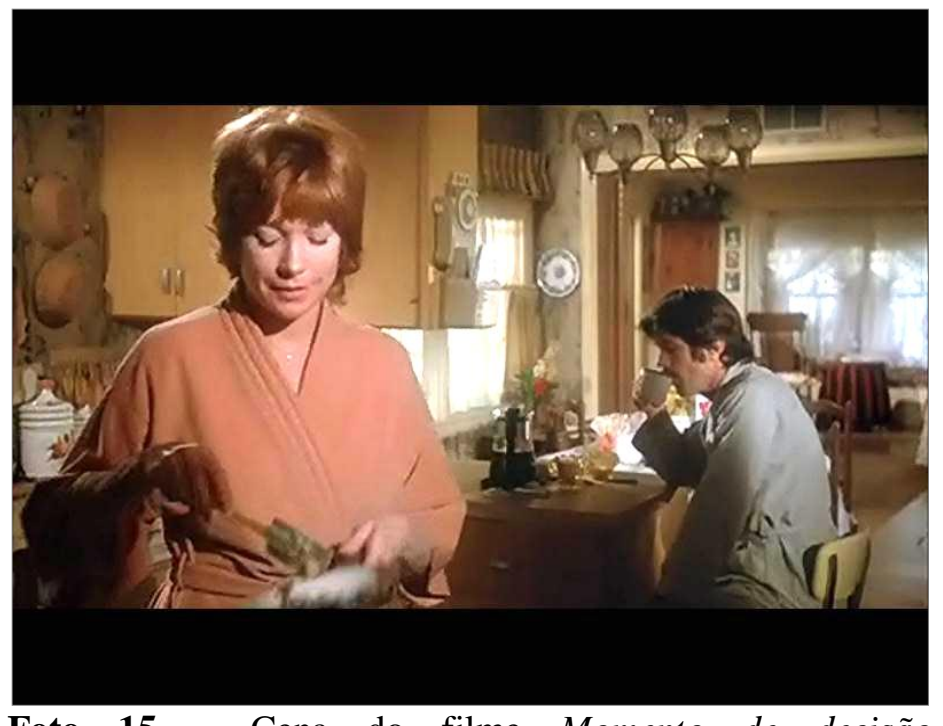

Foto 15 - Cena do filme Momento de decisão (MOMENTO, 1977).

Objetos de cena apropriados, como o apoiador de tecido para a cafeteira e a espátula de silicone, são soluções simples que resultam do trabalho integrado da equipe, viabilizam a mise-en-scène e garantem as condições para a captação dos diálogos.

\subsubsection{Opção de decupagem e a viabilidade do som direto}

Certas demandas de roteiro (como as cenas em que se vê em quadro: carros, máquinas ou motores em real funcionamento) podem prejudicar a inteligibilidade do diálogo captado pelo som direto.

A presença de elementos cênicos "barulhentos" gera, normalmente, planos sonoros com nível de ruído de fundo muito próximo do nível do registro das falas. Em situações extremas, esse ruído de fundo pode ocasionar o "mascaramento" total da voz ou, no mínimo, restringir a possibilidade de edição do material, pois ao integrar uma sequência, o corte de cada plano revelará a interrupção do ruído de fundo que dificilmente será o mesmo para as diferentes posições que o microfone ocupou em cada tomada. Uma solução para camuflar essa descontinuidade sonora é aplicar, durante a edição, o mesmo ruído de fundo, ao longo dos vários planos da sequência, para criar a impressão de continuidade. O limite desse recurso é dado pelo nível total do ruído, resultante da soma do ruído pré-existente no som direto mais o que foi pós-sincronizado na edição. O efeito pode ser uma sequência insuportavelmente 
ruidosa, comprometendo a compreensão das falas proferidas e obrigando a dublagem do som direto durante a pós-produção.

Por razões estéticas ou orçamentárias, a dublagem é evitada por alguns diretores que buscam soluções de filmagem que viabilizem a captação de som direto, mesmo com a existência de elementos ruidosos em cena. Diretores que valorizam o uso do registro direto decupam a cena de forma a adequar a filmagem às necessidades da captação do som direto. Um exemplo desse procedimento pode ser percebido na sequência Despedida na plataforma do início do filme A testemunha $(1985)^{75}$. Uma breve descrição dessa sequência permitirá a identificação dos procedimentos de decupagem que garantiram o registro das falas pelo som direto em uma cena em que um trem está chegando na plataforma da estação.

A Despedida na plataforma é constituída por dezoito planos. No plano 1, acompanhase a caminhada de Daniel na plataforma da estação até o encontro com a família Amish. A câmera caminha com Daniel, revelando os passageiros que aguardam a chegada do trem, a linha férrea e, ao fundo, a família Amish. A caminhada termina quando Daniel toca as costas de Eli, o avô. Ouvimos um ambiente calmo e com vozes indistintas; a voz de Daniel com mais destaque, dizendo "bitte" ao cruzar por duas mulheres na estação; o apito curto de uma buzina distante; e uma música etérea com timbre eletrônico que suavemente permanecerá até o final da sequência.

No plano 2, a câmera aponta para fora da plataforma e ao fundo vemos a linha férrea. Vemos e ouvimos Eli cumprimentando, com certa surpresa, Daniel, que responde ao cumprimento, e em seguida, de forma reverente, cumprimenta Rachel que educadamente responde. A "posição particular da câmera" permite perceber que as falas ("Guten morgen!") mantêm perfeito sincronismo labial com as fontes emissoras. Ouvimos, ainda, em off vozes femininas indistintas um pouco mais distantes e a música que continua.

No plano 3, a câmera numa posição mais baixa e apontando em diagonal para a plataforma, mostra Samuel, que atento acompanhava o dialogo dos adultos. De costas, vemos Daniel abaixando, dirigindo sua atenção ao garoto. Ouvimos a voz de Daniel, sem referência de sincronismo labial, dizendo "So, first time to the big city?". Samuel movimenta a cabeça afirmativamente. As vozes, do diálogo das mulheres, continuam sendo ouvidas ao longe.

\footnotetext{
${ }^{75}$ A testemunha (Witness) narra a história de um garoto Amish que testemunha um assassinato que envolve corrupção policial. A sobrevivência do menino depende da ação de um honesto policial, interpretado por Harrison Ford.
} 
No plano 4, a câmera, na mesma altura do plano anterior, aponta para o interior da plataforma. Vemos e ouvimos Daniel dizendo, a Samuel, com entusiasmo: "You'll see so many things". Vemos a fonte emissora da fala e percebemos o perfeito sincronismo labial. $\mathrm{O}$ diálogo das mulheres continua, e a música sofre pequena variação aumentando a densidade emocional.

No plano 5, com a câmera na mesma posição do plano 3, vemos Samuel e ouvimos a voz de Daniel, em off, dizendo a Samuel: "Close your eyes". A música continua com densidade emocional elevada.

No plano 6, com a câmera na mesma posição da do plano 4, vemos e ouvimos os ruídos provocados pela movimentação de Daniel, que busca um objeto guardado no bolso. Muito distantemente, começa a ser ouvido o ruído cadenciado das rodas metálicas sobre os trilhos, indicando que a composição ferroviária se aproxima da plataforma.

No plano 7, a câmera apontando para baixo, vemos em detalhe a mão de Daniel sobre a mão de Samuel, entregando uma peça de madeira com o desenho de um cavalinho branco. Ouvimos Daniel dizendo: "Open”. Ouvimos ruídos provocados pela movimentação das mãos e a interjeição de surpresa de Rachel ao ser revelado o presente. Em perfeita continuidade, o ruído cadenciado das rodas metálicas sobre os trilhos torna-se mais presente, indicando que a composição ferroviária continua se aproximando da plataforma.

No plano 8, vemos e ouvimos a reação de felicidade de Samuel, que agradece efusivamente: "Danke!". Vemos Rachel abaixada e sorrindo ao lado do filho. Em continuidade com o plano anterior, ouvimos o ruído cadenciado, que fica gradualmente mais intenso, das rodas do trem. Um apito grave e intenso atrai a atenção de Rachel e Samuel, os quais desviam o olhar para a direção na qual o trem se aproxima.

O plano 9, com a câmera apontando na diagonal oposta à do plano 3, num enquadramento maior, revela a chegada à estação da imponente locomotiva que puxa a composição. Vemos e ouvimos o trem. O início do plano é sonoramente preenchido pelo apito que ressoa desde o plano anterior e pelo estalar cadenciado das rodas metálicas sobre os trilhos. Vemos Samuel correndo pela plataforma, ouvimos seus passos e, com extrema clareza, ouvimos a voz de Rachel, que está fora de quadro, pedindo atenção ao filho: "Samuel, careful!’"

No plano 10, vemos Rachel sorrindo, admirada com a alegria de Samuel. Em total continuidade de ação com o plano anterior, vemos o trem em movimento, passando as costas 
de Rachel. O ruído das rodas metálicas sobre os trilhos mantém a mesma cadência e intensidade do plano anterior. Sem falar, Rachel sorri largamente.

No plano 11, a câmera aponta para o interior da plataforma. Vemos Daniel, que dirige a atenção a Rachel, falando suavemente: "You come back soon.”. Ouvimos em off o estalar cadenciado do trem em continuidade com plano anterior.

No plano 12, vemos Rachel olhando fixamente em silêncio para Daniel. O trem continua em movimento atrás dela, porém o estalar das rodas sobre os trilhos tem a sua cadência reduzida, torna-se menos intenso e compartilha o espaço sonoro com estridentes guinchados metálicos provenientes do atrito causado pelo acionamento dos freios. $\mathrm{O}$ som revela que a composição está prestes a parar.

No plano 13, com enquadramento semelhante ao do plano 11, apontando para o interior da plataforma, vemos Daniel em silêncio, sorrindo e acompanhando com o movimento de cabeça a saída de Rachel, que caminha em direção ao filho. Com forte presença sonora, ouvimos em off a voz de Rachel chamando: "Samuel". A cadência e a intensidade das rodas metálicas diminuem significativamente e são totalmente mascaradas pelos guinchos metálicos da frenagem que se estendem até o final do plano. Após a voz de Rachel, ouvimos o ruído de liberação de ar das válvulas dos compressores do sistema de freios.

No plano 14, com a câmera apontando para a mesma direção da do plano 9, num enquadramento mais próximo, vemos Samuel em frente à porta do vagão do trem que se encontra completamente parado. Alguns passageiros descem pela escada, deixam o vagão e cruzam o quadro. Com a mesma intensidade, mantendo continuidade direta com o plano anterior, é ouvido o ruído das válvulas de ar dos freios, o qual eficientemente reforça a completa parada do trem e une os planos com fluidez. Vemos Rachel aproximar-se, um pouco aflita e cuidando do filho; ouvimos seus passos no piso da plataforma e os passos metálicos de Samuel subindo a escada do vagão. Na despedida com o sogro, vemos e ouvimos o conselho enfático, proferido por Eli: “And you be careful out among the English”, ao qual Rachel retribui sorrindo. Rachel sobe no primeiro degrau da escada do vagão e dirige o olhar para a direção de Daniel.

No plano 15, a câmera aponta na direção oposta da plataforma, ponto de vista de Rachel. Vemos Daniel olhando para Rachel e cumprimentando-a simpaticamente. Ouvimos ruídos metálicos, de pequena intensidade, provenientes de passos nas escadas de acesso aos 
vagões. A música, que se manteve presente desde o início da sequência, é agora percebida pela ausência de outras informações sonoras mais significativas na trilha sonora.

No plano 16, a mesma posição de câmera e a continuidade direta da ação do plano 14 indicam que é um mesmo plano de captação que foi desmembrado em dois planos pela montagem. Vemos Rachel retribuir ao cumprimento e encaminhar-se ao interior do vagão. Além dos ruídos provocados pela movimentação da personagem, percebemos um ruído metálico mais intenso indicando ações paralelas que não são visualizadas.

O plano 17 mantém a mesma posição de câmera do plano 15. Vemos Daniel reagir ao olhar de Rachel e, com expressão marota, encaminha-se para fora da estação. Por meio do som inicia-se a partida do trem. Ouvimos dois disparos de ar das válvulas dos compressores do sistema de freios, seguidos de um ruído metálico que remete ao sistema de engate, sucedido por mais dois disparos de ar - com o mesmo ritmo dos anteriores, porém mais intensos -, completando sonoramente a preparação para a saída do trem. A caminhada de Daniel coincidentemente só se inicia após o segundo par de disparos de ar.

No plano 18, a câmera baixa, próxima à linha férrea, revela a locomotiva que já está em movimento. Ouvimos os estalos metálicos das rodas sobre os trilhos iniciando seu compasso ritmado. A música que permaneceu discreta ao longo da sequência assume novo arranjo, torna-se mais imponente, estimulando novas sensações para o início da viagem. Fim da sequência.

A sequência descrita é marcada pela concisão de informações e pela clareza na construção do espaço diegético. A precisa decupagem estruturada pela direção e a habilidosa articulação entre sons e imagens, estabelecida pela montagem, permitem que as intenções sutis que estimulam a progressão da narrativa se revelem na ação dos personagens e descrevem, de forma econômica, a imponente chegada e saída do trem na plataforma. Por meio da aplicação rígida das regras de continuidade física entre os planos, cria-se a impressão de uma ação contínua, possibilitando a compreensão do espaço físico representado. A relação complementar estabelecida entre os sons e as imagens antecipa algumas informações visuais, dinamizando o discurso narrativo, potencializando e unificando os planos de imagem por intermédio do estabelecimento de fluxos sonoros contínuos. 
Coerente com a representação naturalista adotada pelo filme, a sequência Despedida na plataforma é construída segundo os códigos da decupagem clássica ${ }^{76}$ que, com rigorosa manutenção das "famosas regras de continuidade", busca "estabelecer uma combinação de planos de modo que resulte uma sequência fluente de imagens", tornando a montagem invisível a serviço da criação de uma forte impressão de realidade (XAVIER, 1984, p. 24).

Antes de analisarmos especificamente como as opções de decupagem permitiram a captação de som direto na cena, destacamos a importância que a trilha sonora desempenha nessa sequência, resultante da habilidosa articulação, estabelecida pela montagem, entre os sons e as imagens. Em perfeita continuidade, a ação do trem (aproximação, chegada e parada) é descrita de forma ágil e econômica. Para descrever a chegada do trem são usados apenas três planos com a imagem do trem em movimento (planos 9, 10 e 12). O restante da ação é representado por ruídos naturalistas, portanto, identificados ao objeto "trem" que, precisamente dispostos ao longo da sequência, dinamizam a ação representada. A presença do trem é constante, sua aproximação é construída a partir do plano 1, quando é ouvido um apito distante. A chegada do trem na plataforma é feita inicialmente pelo som, por meio do ruído cadenciado das rodas que são ouvidas distantemente no plano 6 e que se prolonga em continuidade até o plano 13, quando é substituído pelos ruídos das válvulas de ar dos freios que indicam a completa parada da composição.

No final do plano 8, o ruído de um apito mais intenso chama a atenção, reforçando a proximidade do trem e provocando a reação de olhar dos personagens, o que impulsiona a narrativa a revelar, pela primeira vez no plano 9, a imagem do trem entrando na plataforma. A reação dos personagens no final do plano 8 evidencia a articulação entre som e imagem determinada pela decupagem que previu, para a situação de filmagem, o momento correto da reação de olhar dos personagens, criando a impressão, após a montagem com o apito póssincronizado, de continuidade espaço-temporal. Durante a filmagem, os atores ouvem e reagem a um apito de trem que só existirá após a sequência montada e sonorizada. A impressão da chegada do trem em ação contínua é construída pelo conjunto de ruídos póssincronizados associados ao trem que estabelecem um fluxo sonoro constante, unificando os planos de imagem. A mesma concisão é percebida na representação da parada do trem, a qual é construída inicialmente apenas pelo som nos planos 11 e 12 - com a substituição

\footnotetext{
${ }^{76}$ Como definido por Ismail Xavier, "o que caracteriza a decupagem clássica é seu caráter de sistema cuidadosamente elaborado, de repertório lentamente sedimentado na evolução histórica, de modo a resultar num aparato de procedimentos precisamente adotados para extrair o máximo rendimento dos efeitos da montagem e ao mesmo tempo torná-la invisível" (XAVIER, 1984, p. 24).
} 
progressiva do estalar das rodas pelos sons metálicos e, posteriormente, pelo ruído das válvulas de ar até a extinção de todos os sons que indicam o movimento do trem. A imagem do trem, já estacionado na plataforma no início do plano 14, ratifica sua parada.

A opção em filmar a cena em vários planos é uma escolha da direção que, entre outras consequências, propicia condições para a captação dos diálogos pelo som direto. A mesma ação, filmada em plano sequência, com o trem chegando em tempo real, inviabilizaria a captação de som direto. Decupar a sequência em planos permite à direção estabelecer os momentos e os enquadramentos para os diálogos. A partir desta definição, os planos com captação de diálogos - nos momentos em que o trem está presente na diegese - são enquadrados de forma a não revelar a sua imagem, podendo ser filmados sem a presença real do trem, evitando os ruídos indesejados e garantindo ao som direto uma captação "limpa" das falas. Com a mesma lógica de decupagem, nos planos em que vemos a imagem do trem em movimento, com a presença real do objeto, não existe a ocorrência de falas com referência de sincronismo labial e, portanto, a tomada da cena não necessita da captação de som direto. Essa lógica de decupagem é verificada ao longo da sequência.

O início do diálogo no plano 2 (cumprimentos entre os personagens), ocorre num momento da diegese em que o trem está distante da plataforma e, portanto, não existe restrição em relação à posição da câmera. A linha férrea é revelada sem a presença do trem, possibilitando a captação simultânea dos diálogos. A continuação da cena, com o diálogo entre Daniel e Samuel (planos 3, 4, 5, 6, 7 e 8, nos quais o trem completa a aproximação da plataforma), é filmada sem revelar a direção da linha férrea da qual o trem se aproxima. Esse posicionamento de câmera desobriga a presença real do trem, permitindo a captação dos diálogos. O ruído das rodas cadenciadas que ouvimos na sequência montada é póssincronizado, permitindo total controle dos níveis relativos das vozes e dos ruídos durante a mixagem.

No plano 9, com a presença real do trem na plataforma, a voz que ouvimos está em off, portanto, sem necessidade de captação de som direto na tomada. Nos planos 11 e 12, com a imagem do trem em movimento, a solução da decupagem é deixar Rachel reagir em silêncio, eximindo a necessidade de captação de som direto. A fala de Daniel no plano 11 é o exemplo emblemático dessa opção de decupagem. A voz emitida com pequena intensidade, coerente com a ação e intenção do personagem, ocorre no momento da diegese em que o trem, muito próximo a ele, está em movimento na plataforma. No entanto, o enquadramento escolhido (câmera apontando para o interior da plataforma) permite que a cena seja rodada 
sem a presença real do trem, garantindo as condições necessárias para que o registro da fala, mesmo com baixa intensidade, seja inteligível. Considerando a realidade do mundo físico, a presença tão próxima do trem em movimento e o ruído por ele produzido exigiriam que o personagem projetasse a voz com um pouco mais de intensidade para ser ouvido. Contudo, no contexto da diegese, a ação é verossímil. As falas finais (o conselho do avô) são proferidas com o trem em quadro. Porém, a hábil decupagem coloca o trem já estacionado, possibilitando que durante a tomada da cena a locomotiva esteja desligada sem produzir ruídos.

Mesmo que parte da sequência tenha sido dublada, o que não parece, a análise realizada não se invalida. A decupagem estabelecida pela direção possibilita que os planos com fala sincrônica sejam captados independentemente da presença real do trem. A articulação estabelecida pela montagem com a pós-sincronização dos ruídos cria a ilusão de continuidade da chegada do trem. A decupagem da sequência Despedida na estação denota a prioridade da direção pelo registro sonoro direto, criando condições adequadas para a captação de falas inteligíveis nessa complexa situação de filmagem. Filmar com som direto obriga a realização de escolhas que viabilizem o trabalho de captação. 

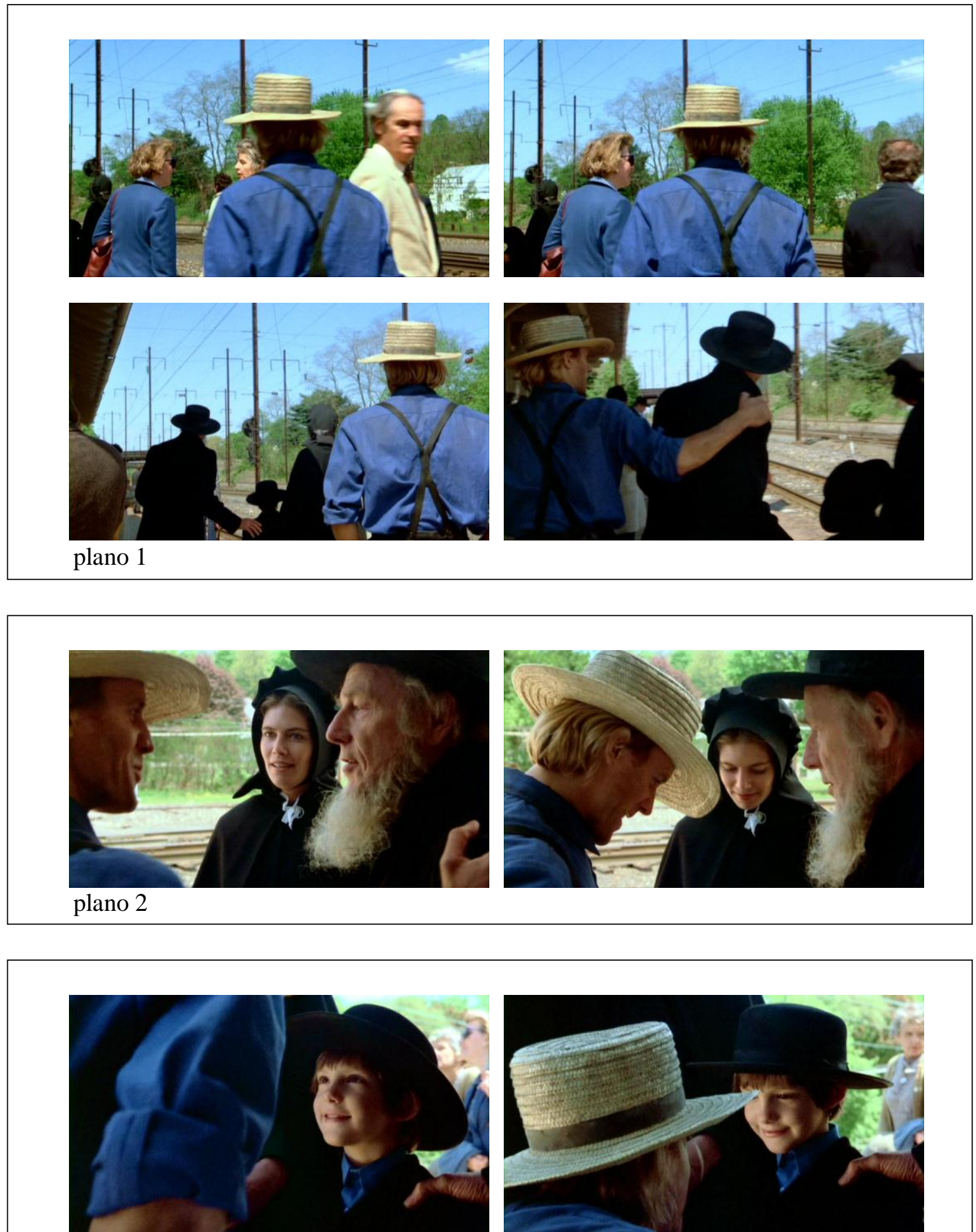

plano 3 

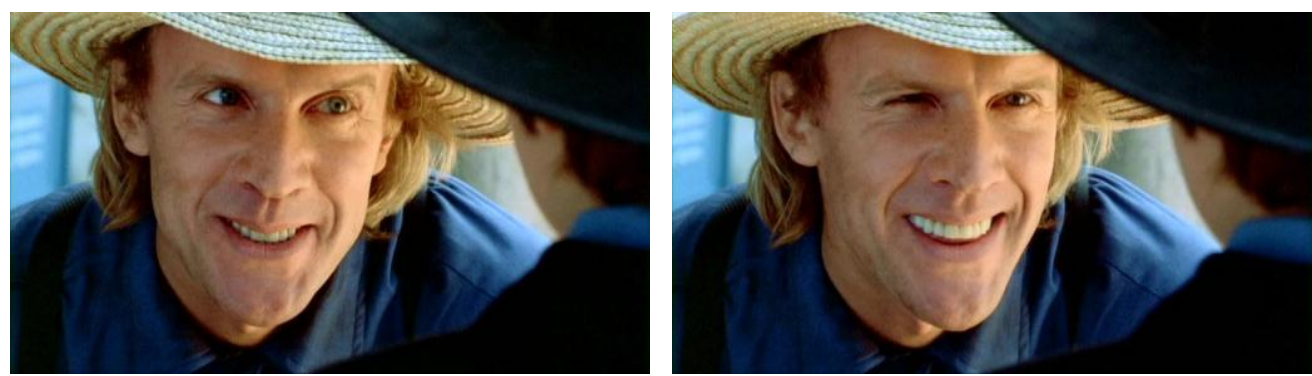

plano 4
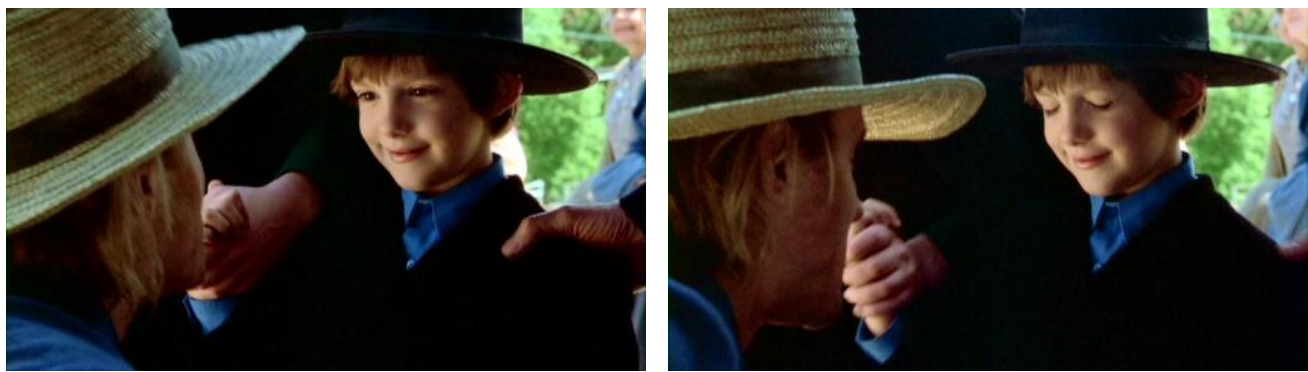

plano 5

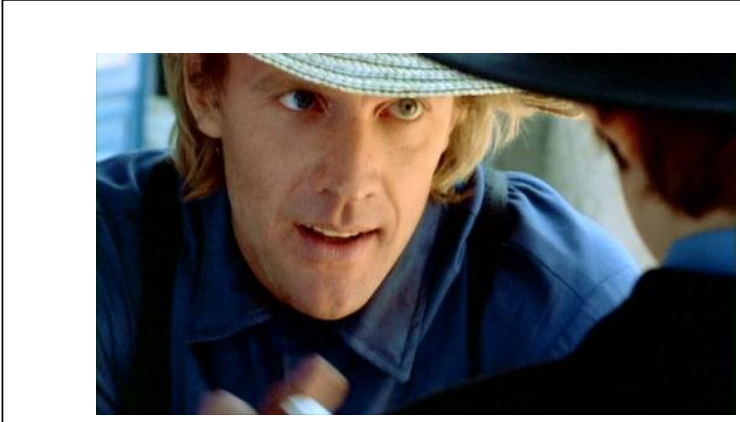

plano 6
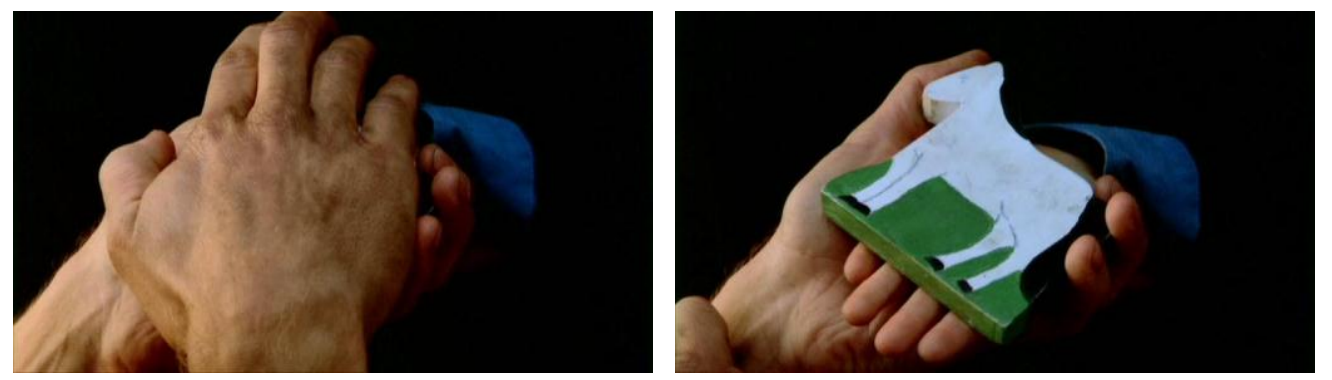

plano 7 

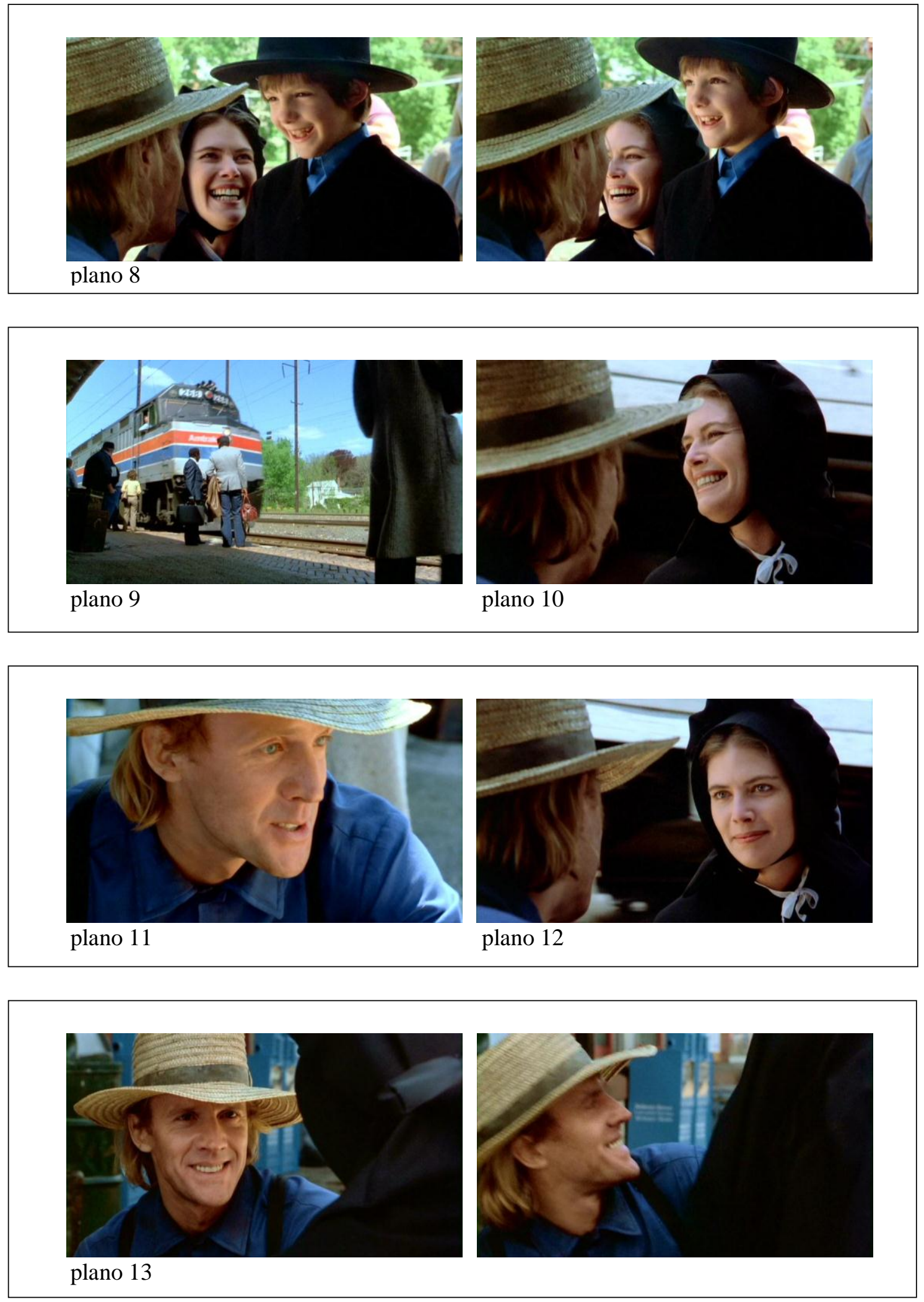

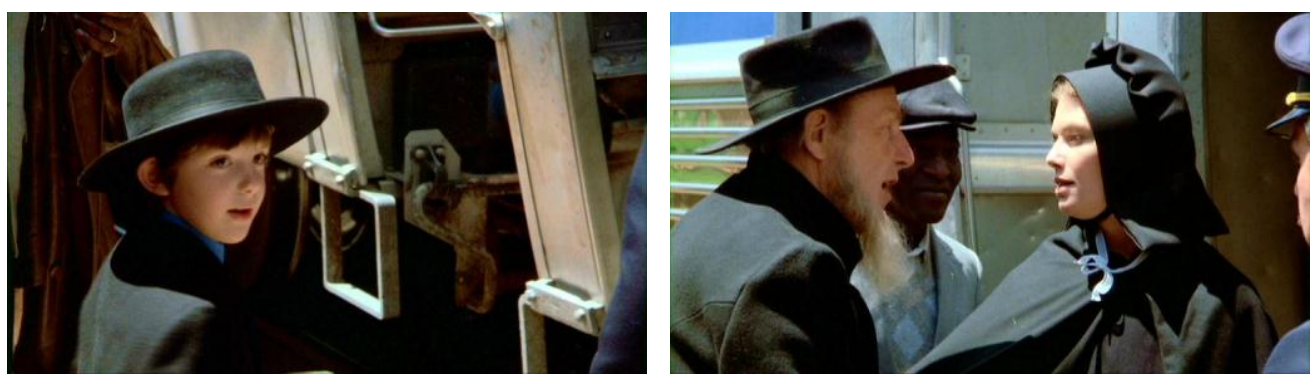

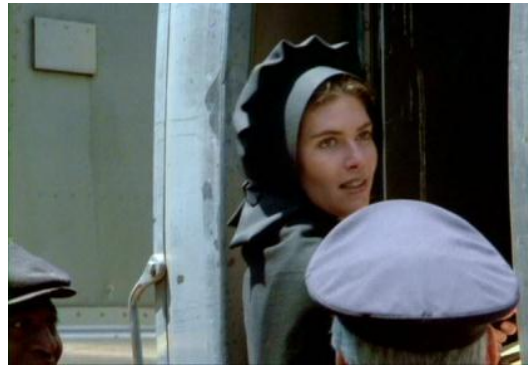

Plano 14

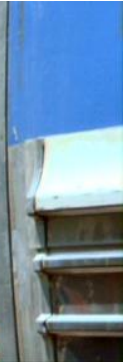

plano 15
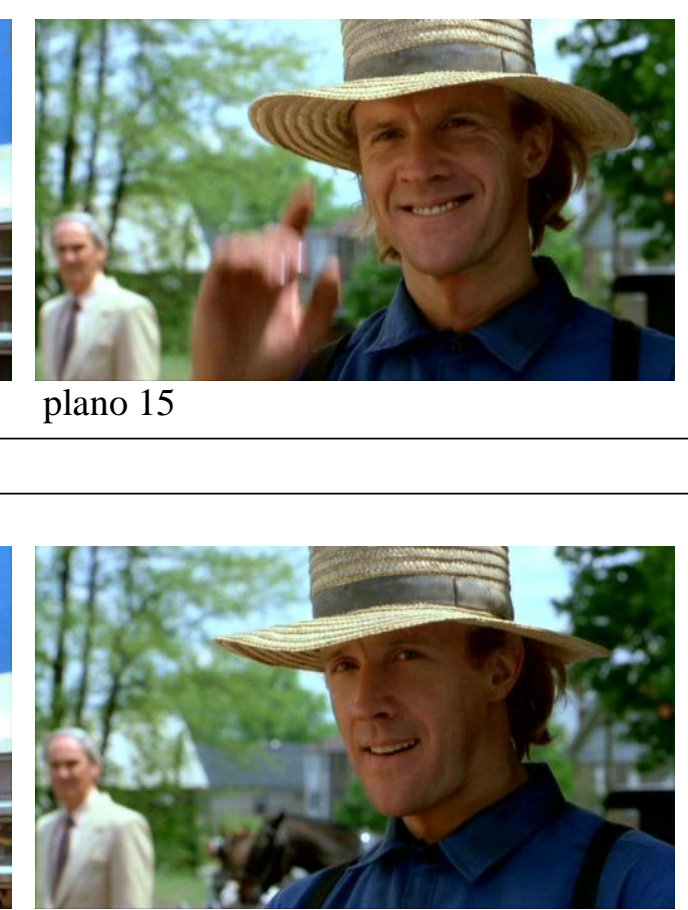

plano 17

Plano 16
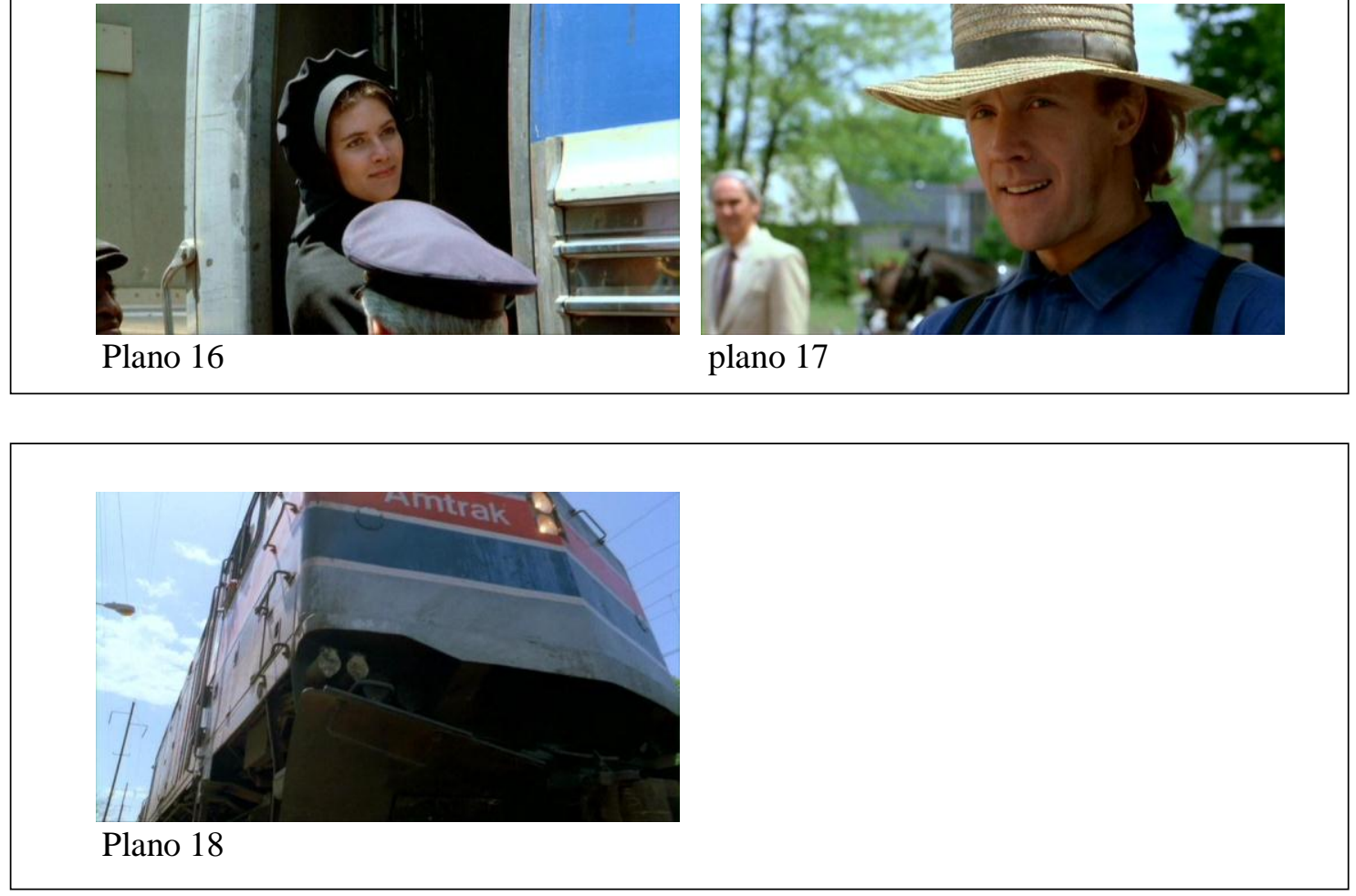

Fotogramas 1 - Sequência Despedida na plataforma do filme A testemunha (1985). 


\section{A CAPTAÇÃO DO SOM DIRETO NOS LONGAS-METRAGENS: CONTRA TODOS E ANTÔNIA}

As propostas estéticas dos longas-metragens Contra todos e Antônia geraram necessidades de realização extremamente complexas para a captação do som direto. Com temáticas e condições de produção distintas, elas exigiram a estruturação de estratégias específicas que atendessem às exigências estéticas e as realidades orçamentárias de cada projeto. Ao longo deste capítulo, será apresentado como as diferentes necessidades dessas produções estimularam a organização e o desenvolvimento do trabalho de captação do som direto, por mim realizado, buscando a adequação técnica e a pertinência estética do som sincrônico nestes filmes.

A análise do trabalho de captação realizado nos dois filmes permite cotejar os diferentes procedimentos empregados e perceber a influencia dos avanços tecnológicos ocorridos entre a realização de Contra todos, em 2002, e de Antônia, em 2005. O registro do som direto de Antônia foi realizado com plataforma de gravação digital portátil multipista, que viabilizou as estratégias de captação empregadas. A altíssima taxa de aproveitamento do som direto na trilha sonora final, apesar da imensa complexidade de realização, foi determinante na escolha, para descrição e análise, desses longas-metragens.

A seguir serão descritos os procedimentos de trabalho empregados em cada um dos filmes e serão apresentadas as condicionantes estéticas que nortearam a realização do som direto. 


\subsection{A REALIZAÇÃO DE CONTRA TODOS}

Rodado em setembro e outubro de 2002, o filme Contra todos é o primeiro longametragem do diretor Roberto Moreira. O filme foi captado principalmente em locações situadas no bairro de Aricanduva, em São Paulo, local onde se passa a história narrada pelo filme. O registro das imagens foi realizado com câmera de vídeo digital ${ }^{77}$, que foi justificada pela proposta estética e orçamentária da produção. O projeto de realização foi premiado no edital da Prefeitura de São Paulo para filmes de baixo orçamento e contou com pouco mais de quinhentos mil reais para a etapa de filmagem. A proposta de realização e a sua justificativa estética decorrem do trabalho realizado para a tese de doutoramento, com o título Deus contra todos, defendida pelo diretor, em 2002. A produção executiva de Contra todos é assinada por Geórgia de Araujo Costa, sócia da produtora Coração da Selva.

\subsubsection{Aspectos narrativos}

A trama narrada pelo longa-metragem Contra todos é inspirada na realidade violenta das grandes cidades. O filme revela um cotidiano de mentiras e traições, envolvendo a vida de uma família de classe média moradora no bairro de Aricanduva, na Zona Leste da cidade de São Paulo. Interpretado por Giulio Lopes, Teodoro é o chefe da família, um pai violento que responde agressivamente às provocações da filha; Soninha é a filha adolescente, interpretada por Sílvia Lourenço; e Cláudia é a mulher adúltera, interpretada por Leona Cavalli.

Teodoro ganha a vida como "justiceiro" ou "matador de aluguel" e tem como parceiro de assassinatos Waldomiro, interpretado por Ailton Graça, que nutre uma paixão não confessada por Cláudia. Teodoro alimenta o desejo de mudar de vida e se envolve extraconjugalmente com a evangélica Terezinha, interpretada por Martha Meola. Cláudia combate o tédio da vida conjugal traindo o marido com Júlio, interpretado por Ismael de Araujo. O cotidiano familiar é rompido com o brutal assassinato de Júlio, fato que desencadeia uma sucessão de eventos que desagregam completamente o já esgarçado núcleo familiar, que culminam com a morte de Teodoro e Cláudia. A total falta de princípios que rege a conduta dos personagens se explicita na sequência final com Waldomiro, que se casa

\footnotetext{
${ }^{77}$ Foram usadas câmeras Sony DSR PD 150 na opção DVCAM.
} 
com Terezinha, a ex-namorada de Teodoro, assumindo uma falsa conversão religiosa e satisfazendo-se ao conquistar os desejos almejados pelo sócio assassinado.

A forte impressão de realidade provocada pelo longa-metragem é o aspecto mais comentado de Contra todos. Esse "novo realismo" do cinema paulista, como foi denominado pelo crítico José Geraldo Couto ${ }^{78}$, é alcançado pela textura despojada das imagens captadas em vídeo digital, pela fluidez do olhar que acompanha as cenas (obtidas por meio da habilidosa câmera na mão do fotógrafo Adrian Cooper), pela simplicidade das locações, e, ainda, pela notável naturalidade das interpretações, resultado do ousado processo de preparação de atores $^{79}$ desenvolvido para o filme. José Geraldo Couto aponta que o despojamento formal é fundamental no realismo alcançado pelo longa, remetendo aos preceitos estéticos defendidos pelo movimento Dogma $95^{80}$. Normalmente associada a aspectos da constituição das imagens, é pouco notada a contribuição da trilha sonora, em particular do som direto, na construção da estética realista do filme. A naturalidade das interpretações se manifesta também na sonoridade das falas dos personagens, as quais são captadas com clareza e numa perspectiva coerente com a imagem, materializando a sensação de "verdade" impressa na cena.

\subsubsection{Condicionantes estéticas}

O início da minha participação no processo de realização de Contra todos foi em uma reunião preparatória, com o diretor Roberto Moreira, na qual foram expostas as premissas estéticas que orientavam a produção do longa-metragem. Em linhas gerais, as questões trazidas pelo diretor orientavam o processo de realização no sentido de construir um filme que fosse marcado por uma profunda impressão de realidade; que privilegiasse a força da atuação naturalista dos atores na representação de um drama ancorado na vida real; que criasse uma narrativa ficcional com traços estéticos do documentário audiovisual. Como publicado posteriormente no site oficial do filme, a premissa central para a realização do Contra todos

\footnotetext{
${ }^{78} \mathrm{Na}$ crítica publicada no caderno Folha Ilustrada, do jornal Folha de São Paulo, em 24 de junho de 2003, intitulada "Dogma Zona Leste".

79 Sobre o processo de preparação dos atores para longa-metragem Contra todos ver http://ideiadoator.sites.uol.com.br/.

${ }^{80}$ Movimento cinematográfico lançado a partir do Manisfesto Dogma 95 assinado pelos cineastas dinamarqueses, Thomas Vinterberg e Lars von Trier. O Manifesto listava uma série de restrições técnicas que preconizavam o resgate de uma estética mais realista e menos comercial.
} 
era a criação de imagens "que transmitissem ao espectador a impressão de que foram flagradas da realidade" 81 .

Nesse encontro, foi apresentada a principal referência fílmica do projeto: o longametragem dinamarquês Festa de família ${ }^{82}$. A partir dessa referência estética foram apontadas as demandas do projeto que implicavam diretamente sobre os procedimentos de trabalho do som direto. Assim como em Festa de família, a infraestrutura técnica deveria garantir a total liberdade de ação para os atores. Não deveriam existir as "amarras" técnicas que tradicionalmente limitam a atuação dos atores durante a tomada das cenas em realizações cinematográficas convencionais. Considerando ainda as necessidades dos atores, era requisito da realização que as reconfigurações do set, para mudança de enquadramento, fossem ágeis, evitando os "tempos mortos" que interferem no trabalho do ator e "esfriam" a atuação. Para satisfazer essas proposições de realização, o suporte de captação da imagem seria o vídeo digital, com câmeras de pequeno porte operadas na mão (a câmera nunca seria usada sobre o tripé). A partir dessas considerações, surgia o desafio de configurar os procedimentos que garantiriam a agilidade e a qualidade necessária ao processo de captação do som direto.

A análise da trilha sonora da referência fílmica permitiu definir os parâmetros de qualidade que regeriam a captação do som direto em Contra todos. A despeito da evidente descontinuidade das imagens e de uma visualidade rude - característica marcante dos filmes alinhados ao movimento Dogma 95 -, a trilha sonora do Festa de família caminha num sentido inverso. Mesmo sem compreender o dinamarquês, pode-se perceber que o som das falas é presente, destacado do ambiente de fundo, e a montagem descontínua das imagens é suavizada pela sensação de continuidade criada pela trilha sonora. No Festa de família, a trilha sonora serve de lastro para os voos descontínuos e fragmentados realizados pela imagem, mesmo que tenha seguido as regras do Manifesto em relação à trilha sonora ${ }^{83}$, a característica do som direto não se distanciava significativamente das premissas seguidas em

\footnotetext{
${ }^{81}$ Roberto Moreira, em entrevista no site oficial do filme.

${ }^{82}$ FESTA de família. Direção de Thomas Vinterberg. Brigite Hald: Dist. October Films, 1998. (105 min), son., color,; $35 \mathrm{~mm}$. Esse filme o primeiro longa-metragem lançado seguindo os preceitos do Manifesto Dogma 95. Festa de Família narra a comemoração de aniversário de sessenta anos do patriarca Helge, em grande estilo reúne toda a família em uma bela propriedade no campo. A expectativa de um encontro amistoso e fraterno é gradualmente revertida a partir das inesperadas e traumáticas recordações que se revelam. A rusticidade estética, fiel aos princípios do Manifesto Dogma 95, imprime um forte tom realista, potencializando o drama e as tensões habilmente alinhavadas pela narrativa.

${ }^{83}$ Segundo o Manifesto Dogma 95 o som jamais deveria ser produzido separadamente da imagem ou vice-versa, assim como, a música não poderia ser utilizada a menos que ressoe no local onde se filma a cena.
} 
realizações convencionais. Portanto, para não correr o risco de perder o alicerce de sustentação da representação audiovisual, buscaríamos, em Contra todos, a captação do som direto com o padrão de qualidade tradicional: registro da voz claramente inteligível; plano sonoro verossímil com a imagem; e homogeneidade entre diferentes planos de uma sequência.

Para garantir a premissa básica de Contra todos foram definidos procedimentos para organizar o processo de realização. O Dogma Zona Leste que visava resguardar o espaço de criação dos atores pode ser sistematizado nos seguintes tópicos:

- Criação dos personagens por meio de jogos de improvisação. Os atores trabalhariam na construção dos personagens sem conhecimento prévio do roteiro do filme, cada ator teria total liberdade para criar as motivações de seu personagem.

- O roteiro apresentava a progressão das cenas sem diálogos redigidos. O detalhamento da ação e a criação dos diálogos seriam improvisados durante a tomada das cenas. Os conteúdos das falas seriam elaborados durante a própria captação.

- Simplificação do aparato técnico de captação de imagem. Opção pelo vídeo digital DV com redução dos custos com material sensível. Câmera leve para ser operada na mão. Aparato técnico de iluminação reduzido para propiciar agilidade no processo de captação. Despojar o processo de produção para concentrar os esforços no trabalho dos atores e na construção das cenas.

- A equipe técnica seria o mais "enxuta" possível.

- A atenção da câmera e do som seria conduzida pela mise-en-scène. A câmera assumiria a posição de observador participativo interagindo com a ação. A câmera e o som estariam a serviço da cena até o limite das possibilidades técnicas de cada suporte de captação.

- As cenas seriam captadas por meio de longos planos-sequências, com ação e diálogos improvisados, que se desenvolveriam sem prévia decupagem. Coerente com os pressupostos da improvisação ${ }^{84}$, cada cena seria captada uma única vez.

\footnotetext{
${ }^{84}$ A realização de cenas improvisadas, sem texto previamente escrito e sem falas decoradas, objetivava alcançar atuações naturais e intensas. A coerência com esse procedimento determinava que apenas
} 
- Os espaços das cenas seriam estruturados em locações onde a trama se desenvolveria. A cenografia das locações seria constituída a partir de elementos pertencentes às próprias locações ou com referência na realidade da vizinhança. Cada ator participaria do processo de criação cenográfica do espaço cênico de seu personagem.

Esses procedimentos visavam à constituição de uma estética realista ao mesmo tempo em que se harmonizavam com a realidade orçamentária do projeto.

\subsubsection{Pré-produção}

A proposição do Dogma Zona Leste de formar uma equipe de filmagem reduzida determinou que a equipe de som direto fosse constituída por mim e por Adriano Kakazu, que faria seu primeiro longa-metragem como microfonista. As tradicionais funções executadas pelo técnico de som e pelo microfonista foram, por diversas vezes, invertidas com o técnico de som assumindo a operação do boom e o microfonista responsabilizando-se pelo registro do som. A inversão de funções foi realizada em cenas mais complexas, que envolviam intenso deslocamento e vários atores contracenando simultaneamente. Nessas circunstâncias, em geral, o único espaço para posicionamento do operador de microfone era atrás do fotógrafo, passando o boom por cima da câmera. A viabilização dessa estratégia exigia grande experiência e estatura física adequada.

Em função das demandas do roteiro, percebidas durante a análise técnica, foi definida a constituição de dois conjuntos de equipamentos que seriam utilizados no processo de realização: uma configuração portátil que garantiria a mobilidade necessária para as cenas externas e uma configuração fixa para as captações internas. A definição do cronograma de filmagem possibilitou o estabelecimento com precisão de períodos de uso de cada um dos conjuntos, o que reduzia os gastos com equipamentos locados de terceiros e adequava as necessidades de infraestrutura técnica aos limites impostos pelo baixo orçamento da produção.

uma tomada de cada cena fosse realizada, pois, em tese, a repetição da cena seria incoerente com o princípio da improvisação e tenderia a criar atuações mecanizadas e sem vigor. 
A despeito do uso de câmera de vídeo digital para a captação das imagens, o registro de som foi feito em plataforma independente, configurando um double system. As limitações impostas pelo single system, analisadas no capítulo anterior, determinaram a opção pela plataforma independente para a gravação do som. A plataforma para o registro sonoro, utilizada em Contra todos, foi um gravador digital com duas pistas independentes de gravação da marca inglesa HHB, modelo PORTADAT PDR1000TC ${ }^{85}$. A gravação de som digital baseada em fita magnética DAT (digital audio tape) era a tecnologia mais empregada nas produções audiovisuais na época da realização do filme.

A configuração dos equipamentos para as cenas externas era constituída pelo mixer portátil da empresa norte-americana PSC, modelo Alphamix $-4^{86}$, e por um conjunto de microfones com direcionalidade mais fechada. Nas situações de caminhadas pelas ruas com a câmera posicionada ao longe, estava prevista a utilização de um microfone de lapela sem fio. Da mesma forma que na captação de documentários, esse arranjo estaria preso ao corpo do técnico de som para garantir total mobilidade. A configuração destinada à captação das cenas internas previa o uso de equipamento de mixagem de mesa e um conjunto de microfones com direcionalidade mais aberta. A plataforma de registro seria a mesma nas duas configurações.

A escolha das locações foi resultado de um cuidadoso trabalho de pesquisa, o qual considerou aspectos relacionados às necessidades narrativas, a logística e a adequação técnica para a captação da imagem e do som. Seguindo as premissas de realização, as locações deveriam estar no bairro de Aricanduva. Após visita e avaliação, várias locações, previamente selecionadas pela produção, foram vetadas por mim, por não apresentarem condições adequadas para a captação de som direto.

Por ordem de importância, no roteiro, as duas principais locações eram: Casa de Teodoro, onde a maior parte do filme seria rodado, aproximadamente três de um total de cinco semanas, e Casa de Teresinha, na qual cenas de extrema dramaticidade estavam previstas, porém com menor incidência no roteiro. A locação escolhida para a Casa de Teodoro ficava em uma área mais antiga do bairro, pouco adensada e, portanto, com nível de

${ }^{85}$ O PORTADAT PDR1000TC, da HHB, dividia o mercado dos gravadores digitais profissionais portáteis com a Fostex que produzia, na época da realização do Contra todos, o modelo PD4 que, em vantagem sobre o PORTADAT da HHB, possuía um mixer embutido que possibilitava a entrada de até três microfones que podiam ser mixados para duas pistas de gravação independentes.

${ }^{86}$ O Alphamix-4 é um mixer portátil, profissional, com a tradicional configuração com 4 canais de entrada e duas saídas principais. Oferece os principais recursos de alimentação de microfone, de filtragem dos sinais de entrada e a possibilidade de monitoração auditiva e visual independente de cada canal. 
ruído ambiente relativamente baixo. Algumas fontes de ruídos intermitentes, tais como, o ponto final de uma linha de ônibus e um lava rápido de automóveis, não invalidaram a escolha. A locação escolhida para a Casa de Teresinha era um imóvel térreo, situado em uma área mais adensada do bairro e, portanto, com um nível de ruído ambiente um pouco mais intenso. Para atenuar a incidência dos ruídos provenientes da rua, propus que utilizássemos como espaço cênico apenas os cômodos mais afastados da rua, o que tornou a locação tecnicamente viável para o som.

Para diminuir a reverberação e a incidência de ruídos externos, as duas locações sofreram intervenções acústicas antes do início das filmagens. Para redução da reverberação foi montada, em todos os cômodos, uma estrutura apelidada de tenda árabe ${ }^{87}$, que nada mais é do que uma forração de tecido próxima ao teto, cobrindo o set. Em conformidade com as necessidades da imagem, foram instaladas peças de tecido de cor branca.

Este tipo de tratamento, quando comparado com as técnicas usualmente empregadas, apresentava-se mais adequado à proposta de realização de Contra todos. A estratégia mais comum é a colocação de mantas de $\operatorname{som}^{88}$ ao redor do set, nos locais que não serão enquadrados pela câmera. Essa opção gera uma estrutura que ocupa muito espaço, dificulta a locomoção da equipe e dos atores e impede a livre movimentação da câmera, pois cria um anteparo de tecido próximo à cena. Em Contra todos, a almejada liberdade de ação dos atores, acompanhada agilmente pela câmera, conflitava com a utilização do método tradicional para a redução da reverberação.

Na locação Casa de Teodoro, além do tratamento para baixar a reverberação, foram instalados vidros temperados por fora das janelas de cada um dos cômodos do imóvel. Foi criado um sistema de fixação que permitia a rápida colocação ou remoção dos vidros, dependendo da necessidade das cenas. Esse tratamento propiciou um poderoso isolamento sonoro do mundo exterior. As demais locações do filme, as com menor ocorrência no roteiro (por exemplo: quarto de hotel no centro de São Paulo, açougue na periferia, hospital, e bar na

\footnotetext{
${ }^{87}$ Nessa versão da tenda árabe, o tecido foi sustentado por uma estrutura constituída por fios de barbante paralelos que atravessavam os cômodos no sentido da largura, sobre esses fios foram dispostos tecidos, formando ondas, com aproximadamente $30 \mathrm{~cm}$ de raio, que ocupavam toda a área do teto criando uma poderosa superfície de absorção.

${ }^{88}$ Esses artefatos são grandes peças de tecido acolchoado, medindo aproximadamente $3 \mathrm{~m}$ por 1,5m, sustentados por sarrafos de madeira que, por sua vez, são suspensos por tripés. Além de reduzirem a reverberação pela capacidade de absorção sonora, as mantas de som são utilizadas como isolantes acústicos para o fechamento de vãos de portas e janelas, diminuindo a incidência de ruídos externos.
} 
periferia) receberam tratamento acústico no dia da filmagem por meio do uso das mantas de som dispostas convenientemente para cada uma das situações de filmagem.

\subsubsection{Estratégias de captação}

Os procedimentos de captação do som direto foram organizados para garantir total liberdade de ação para os atores. A realidade orçamentária da produção e a busca por uma sonoridade que materializasse a "impressão de que foram flagradas da realidade" determinaram que a captação fosse prioritariamente realizada com microfones direcionais operados por boom. A representação sonora mais natural obtida por esses microfones, graças à preservação das características acústicas do espaço no qual a fonte sonora é captada, foi decisiva no predomínio dessa opção. A escolha do tipo de microfone empregado e a estratégia de captação foram condicionadas pela mise-en-scène e pelas características do espaço cênico, gerando inúmeras configurações particulares.

Nas captações internas foram priorizados microfones com direcionalidade mais aberta, foram empregados: o microfone da fabrica alemã Sennheiser modelo MKH 435, um cardioide curto, com sonoridade brilhante; e o microfone modular ${ }^{89}$, da fábrica Alemã Schoeps, com a cápsula cardioide $\mathrm{MK}^{90}$. O microfone modular Schoeps com cápsula MK4 e o acessório denominado Swivel GVC $^{91}$ (ver Foto 16) foi a configuração mais funcional, devido à reduzida dimensão que o microfone adquire, para as longas cenas nas quais os atores se deslocavam pela casa, passando debaixo dos batentes das portas enquanto proferiam suas falas.

\footnotetext{
${ }^{89}$ Microfones modulares são os microfones com cápsulas intercambiáveis. Consistem na combinação de duas unidades básicas: cápsula e amplificador. Entre a cápsula e o amplificador podem ser inseridos diversos acessórios como cabos, atenuadores e filtros.

${ }^{90}$ A cápsula MK4 tem direcionalidade mais aberta sendo pouco restritiva aos sons fora de eixo.

${ }^{91}$ O Schoeps Swivel GVC é um acessório que apresenta duas peças articuladas que podem ser anguladas entre $0^{\circ}$ até $120^{\circ}$, trabalhando com o "cotovelo" a $90^{\circ}$ é possível operar o microfone no boom, acima da linha superior do quadro, em espaços extremamente reduzidos.
} 


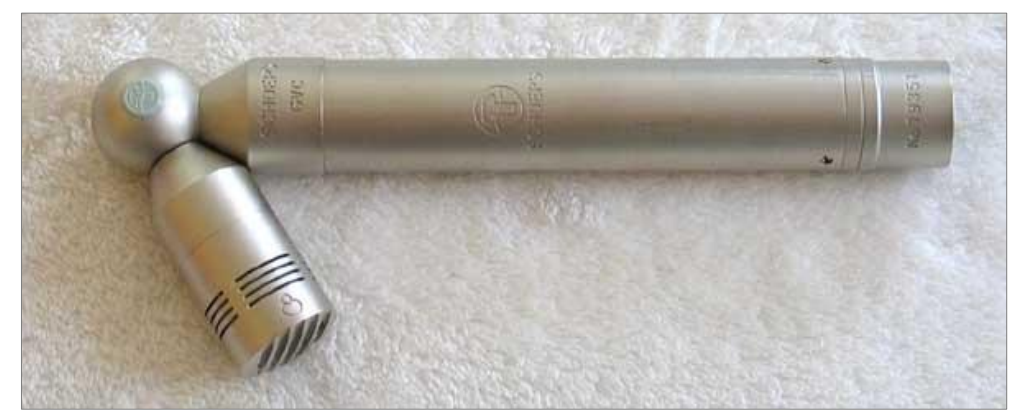

Foto 16 - Microfone modular da Schoeps com o swivel entre a cápsula e o amplificador.

Foi decisiva a escolha de microfones direcionais com ângulo de captação mais aberto para a realização de Contra todos, que se baseava em cenas improvisadas, sem decupagem e com vários atores contracenando simultaneamente. Com os microfones cardioides mais abertos, a manutenção do eixo de captação em relação à fonte sonora pode ser garantida com pequenas correções na posição do boom, favorecendo uma captação com presença homogênea das vozes mesmo com vários atores em cena.

Nos longos planos-sequências com o acompanhamento do deslocamento dos atores através dos diversos cômodos da Casa de Teodoro, aconteceu um problema que não havia sido previsto durante a análise técnica. Dependendo da mise-en-scène no interior da casa, a partir de certo momento da tomada, os cabos de áudio que faziam a conexão entre o boom e a mesa de som eram enquadrados pela câmera. Essa situação inviabilizava uma das propostas básicas da realização de Contra todos. Para solucionar esse problema, foi adaptado um sistema de radiotransmissão para enviar o sinal do microfone, operado pelo boom, para a mesa de som. O sinal obtido por esse sistema era menos cristalino que o sinal enviado por cabo, no entanto, garantia uma importante premissa de realização do filme.

A portabilidade foi o principal atributo considerado na configuração do equipamento para a captação das cenas externas. A partir de experiências anteriores em realizações documentárias, foi montada uma configuração que visava garantir agilidade na execução das tarefas, preservando a mesma fidelidade sonora do restante do trabalho. Nas cenas com grandes deslocamentos, a estratégia para a captação de som se aproximava dos procedimentos realizados em documentários com a utilização do mixer portátil e do gravador presos ao corpo e o boom operado pelo próprio técnico de som. Nessas situações, a minha sintonia com o fotógrafo era fundamental, pois eu acompanhava os movimentos de câmera, antecipando-me às correções de enquadramento. Nas cenas externas, foi priorizado o uso de microfones direcionais com ângulo de captação mais fechado e foram empregados dois modelos de 
microfones supercardioides da marca alemã Sennheiser, o MKH $416^{92}$ e o MKH $816^{93}$. No cotidiano do trabalho, esses microfones são simplesmente chamados de 416 e 816.

O detalhamento do processo de realização de algumas sequências do Contra todos, que será feito a seguir, permite revelar as variáveis que interagiram na determinação dos procedimentos de captação e analisar os resultados obtidos com a estratégia adotada. As sequências selecionadas representam um painel diversificado das situações encontradas, exemplificando o método de trabalho do som direto na realização do Contra todos.

\subsubsection{Sequência 01 - Assistindo vídeo na casa de Teodoro}

Na sequência de abertura do longa-metragem, há Teodoro, Soninha, Júlio e Waldomiro conversando e assistindo a um vídeo familiar na sala da casa de Teodoro. Cláudia está na cozinha preparando o jantar.

\footnotetext{
${ }^{92}$ O microfone Sennheiser MKH 416 é um direcional com padrão de captação supercardioide. Ele é conhecido no mercado pela extrema versatilidade, tem sonoridade brilhante e alta discriminação entre o sinal direto e o ruído de fundo. A direcionalidade do microfone é obtida por meio do princípio acústico denominado tubo de interferência. O MKH 416 mede $20 \mathrm{~cm}$ de comprimento, sendo denominado no mercado norte-americano como short shotgun microphone.

${ }^{93}$ O microfone Sennheiser MKH 816 é um direcional com padrão de captação supercardioide. Com altíssima discriminação entre o sinal direto e o ruído de fundo. A maior direcionalidade desse microfone é determinada por um tubo de interferência com o comprimento de $54 \mathrm{~cm}$ sendo, por isso, conhecido no mercado norte-americano como long shotgun microphone. Apesar da incrível sonoridade, a sua utilização é restrita em função do comprimento e do peso que limitam a sua operação pelo boom.
} 

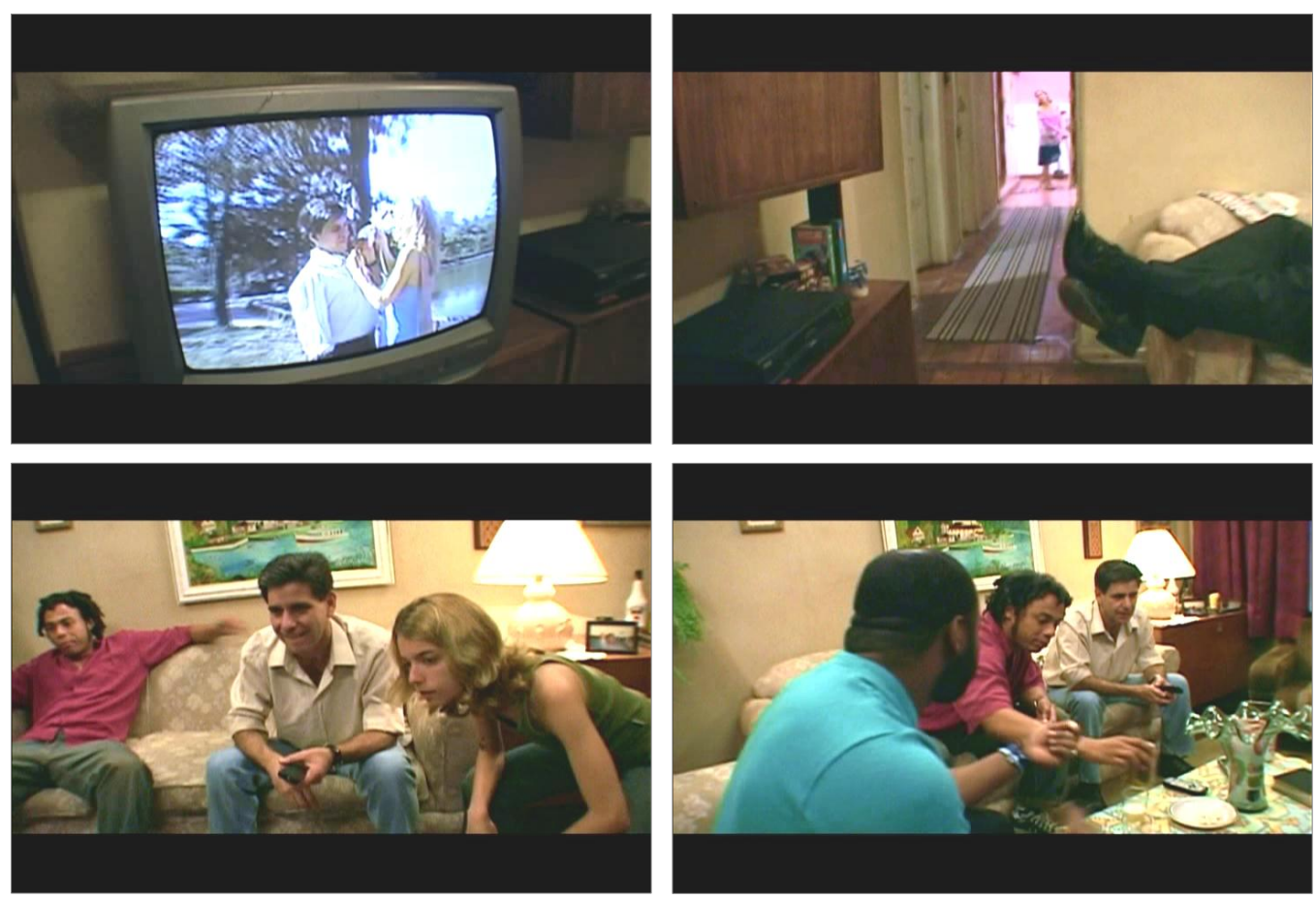

Fotogramas 2 - Sequência 01, Assistindo vídeo na casa de Teodoro (CONTRA, 2005).

A cena se inicia com a imagem da televisão, onde se vê um vídeo de Cláudia e Teodoro em cenas românticas. A correção lateral da câmera mostra ao fundo do corredor Cláudia, que pede a ajuda de Soninha para finalizar o jantar. A câmera continua a correção lateral, enquadrando a sala com Waldomiro, Júlio, Soninha e Teodoro, que zombam animadamente das imagens assistidas na televisão. Soninha se levanta, atendendo ao chamado de Cláudia, e, ao passar por Júlio, é provocada por ele e reage intensamente. Vemos Soninha caminhando pelo corredor em direção à cozinha e na sequência acompanhamos o diálogo de Waldomiro e Teodoro, que provocam Cláudia em relação ao jantar. Waldomiro e Júlio saem de quadro em direção à cozinha, fica Teodoro compenetrado, assistindo ao vídeo. O som da sequência antecede a imagem. Sob as cartelas de abertura, ouvimos o ruído da chuva, vozes e risadas. Entendemos que as vozes ridicularizam as imagens vistas na televisão e a atenção da câmera é desviada pela voz de Cláudia. Nitidamente, é possível notar a existência de vozes que emanam do espaço da sala e de vozes que vêm do aparelho televisor. As brincadeiras entre os personagens denotam um clima de descontração e amizade. Acompanhamos, pelo som, a caminhada de Waldomiro e Júlio até a cozinha.

Captar o som direto dessa sequência envolveu equacionar as seguintes questões: a cena acontecia em ação contínua registrada em plano-sequência; existia a participação de quatro personagens próximos à câmera e um personagem distante, todos com falas 
improvisadas; mesmo fora de quadro os personagens continuavam participando da ação, por meio de falas em off; a câmera realizava um movimento complexo que revelava quase todo o espaço da sala por intermédio de correções panorâmicas e de um deslocamento frontal.

A captação de som da cena foi feita com o emprego de dois microfones gravados em pistas separadas no gravador DAT. Para garantir a presença da voz de Cláudia, foi afixado um microfone na cozinha, próximo ao final do corredor, com o eixo de captação orientado na direção da personagem, foi empregado MKH 416 sustentado por um pedestal. As paredes da cozinha que estavam fora de quadro foram cobertas com mantas de som para redução da reverberação. Para garantir a presença equilibrada das vozes dos personagens na sala, foi usado o microfone MKH 435, que possuía eixo de captação mais aberto e estava sendo operado pelo boom. Além do tratamento acústico feito com a tenda árabe, o mobiliário e as cortinas reduziram o campo sonoro difuso, aumentando a presença das vozes.

O correto posicionamento do boom, para garantir o eixo de captação e a consequente sensação de presença homogênea das vozes, foi resultado de uma habilidosa movimentação do microfone. Nessa cena, houve a necessidade de inversão de funções entre o microfonista e eu, o técnico de som, situação em que realizei a operação do microfone. . Escolhidos os microfones, o grande desafio para a captação de som da cena foi encontrar a mecânica de movimentação que viabilizasse o posicionamento do boom em harmonia com o deslocamento e os enquadramentos realizados pela câmera. A minha movimentação junto ao operador de câmera foi precisamente coreografada. Essa cena foi rodada no primeiro dia de filmagem, durante a sua realização percebemos as dificuldades impostas pelo Dogma Zona Leste e a necessidade de flexibilizar o método de realização em algumas situações. Para garantir a qualidade do som dessa sequência, solicitei que as falas de Cláudia na cozinha fossem sempre proferidas em direção ao corredor, favorecendo a posição do microfone que estava colocado na cozinha, o que de certa forma era coerente com a ação, na medida em que a personagem estava conversando com as pessoas que estavam na sala. Além disso, foi solicitado que os personagens permanecessem em silêncio durante a caminhada no corredor, pois aquela área não possuía cobertura de microfone. Assim, quando Soninha vai para a cozinha, suas falas terminam no momento que ela entra no corredor e não interferem no diálogo que acontece a seguir entre Waldomiro e Teodoro. Após a saída de Waldomiro e Júlio da sala, ouvimos a voz de Waldomiro discutindo com Cláudia. Waldomiro caminhou em silêncio no corredor e esperou chegar à área coberta pelo microfone da cozinha para proferir seu texto. 
A dificuldade da manutenção das vozes com presença homogênea pode ser percebida, no filme montado, no momento da cena em que a câmera reenquadra a sala e vemos Waldomiro em primeiro plano e Teodoro ao fundo. A voz de Waldomiro dizendo: "E aí, vamos ficar só nos amendoins, não vai sair o rango, não?!”, é ouvida com forte presença. Já a resposta de Teodoro fica distante e o início de sua fala é quase inaudível, resultado da impossibilidade de aproximação do boom. Essa diferença de presença pode ser justificada pela perspectiva da imagem, no entanto, tecnicamente, é uma deficiência de captação.

As vozes provenientes da televisão e o som da chuva ouvida na trilha sonora foram pós-sincronizados durante a edição. A sonoridade da voz de Cláudia, captada em primeiro plano pelo microfone colocado na cozinha, foi devidamente ajustada (controle de nível e equalização) durante o processo de mixagem da trilha sonora para adequar-se à perspectiva da imagem.

O primeiro dia de filmagem de Contra todos foi decisivo para a definição do método de trabalho com a revisão de algumas premissas do Dogma Zona Leste. Após a captação da primeira cena, a resposta à clássica pergunta da direção (se o som havia valido) não foi muito animadora. O som direto do plano-sequência apresentava bons momentos e alguns trechos inaproveitáveis, causados por diferentes motivos, tais como: atraso na correção do microfone, ruído da manipulação do boom, ocorrência de ruídos fora de cena ou ruídos provocados pela própria equipe que prejudicavam a compreensão das falas ou revelavam o processo de realização, inviabilizando aquele trecho do plano de som. Ficou evidente que naquelas condições de realização (longos planos-sequências e atuação improvisada) seria praticamente impossível garantir um registro sonoro com qualidade do início ao fim do plano. A única solução para garantir o som direto de toda a ação seria a repetição das tomadas. Assim, solicitei à direção que refizéssemos a tomada daquela cena, o que forneceria material sonoro para a montagem, pensando na possibilidade de utilizar sons oriundos de tomadas diferentes. Porém, essa proposta rompia com a premissa de uma única tomada por cena, o que objetivava preservar o frescor do improviso. Diante da solicitação do som direto, a direção decidiu flexibilizar o método de trabalho, assumindo a repetição das tomadas. A cada nova tomada de cena, a câmera centraria a atenção sobre um personagem e os atores não deveriam preocuparse com a manutenção exata das falas ou dos movimentos de uma tomada para outra.

Durante a montagem de Contra todos, foi verificado o acerto na mudança do método de trabalho, pois as várias tomadas de cada plano-sequência forneceram matéria-prima para a edição de imagem, criando várias opções de cortes dos planos-sequências que permitiram à 
montagem escolher o ritmo do filme, o que seria inviável se a premissa original de filmagem tivesse sido mantida.

\subsubsection{Sequência 18 - Teodoro espanca Soninha}

Na sequência 18, Teodoro e Cláudia conversam na cozinha antes do jantar. A chegada de Soninha com uma postura desafiadora desencadeia uma das cenas mais violentas de Contra todos.
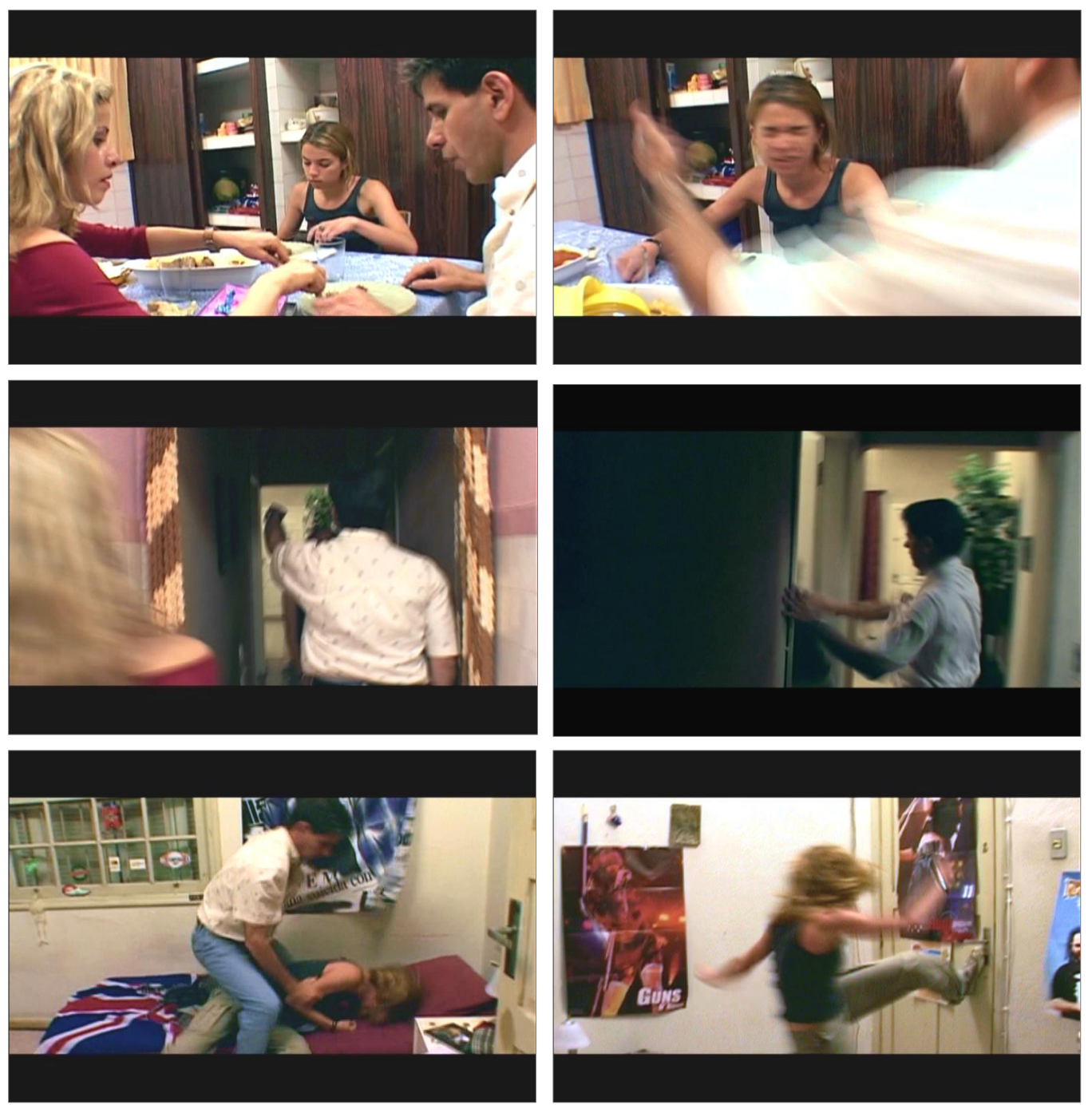

Fotogramas 3 - Sequência 18, Teodoro espanca Soninha (CONTRA, 2005). 
A sequência se inicia com Teodoro entrando na cozinha, onde encontra Cláudia que está preparando o jantar. Teodoro presenteia Cláudia, que reage calorosamente. O clima de alegria rapidamente se desfaz quando Cláudia, desconfiada, percebe uma corrente de ouro no pescoço do marido. Cláudia põe a mesa e Teodoro chama a filha para jantar. Soninha se senta à mesa e desafiadoramente se contrapõe ao pai. À provocação de Soninha, Teodoro reage de forma explosiva, espancando a filha violentamente. Aos socos e pontapés, Soninha é conduzida ao quarto. Transtornados, pai e filha se recolhem em seus respectivos quartos.

Em função da contusão sofrida pela atriz, durante a ação do espancamento, a cena foi repetida apenas duas vezes, gerando dois longos planos-sequências. Na montagem, o planosequência foi editado: foi suprimida grande parte da surra que ocorreu no interior do quarto e foi antecipado um plano do final da sequência (Cláudia em pé na cozinha vista do corredor) para garantir a continuidade da ação. A despeito dos cortes, considera-se a cena como um plano-sequência, respeitando o processo de captação que se desenvolveu de forma contínua. O plano de Soninha chutando a porta foi captado em tempo real por uma segunda câmera, posicionada no fundo do quarto, que registrava a ação da filha após Teodoro deixar o quarto, sendo acompanhado pela câmera principal.

A realização dessa cena apresentou três grandes desafios para a captação do som direto: o primeiro: acompanhar a intensa movimentação dos personagens em espaços muito reduzidos, com inversões de enquadramentos que revelavam quase todos os cantos da casa; o segundo: registrar a reação de Soninha em tempo real dentro do quarto após a surra enquanto Teodoro era acompanhado de volta à cozinha; o terceiro: acomodar num registro fiel a dinâmica sonora existente na cena - desde falas suaves no momento romântico entre o casal até a fortíssima intensidade durante a briga entre pai e filha.

A estratégia de captação foi montada com emprego de dois microfones supercardioides MKH 416, que prioritariamente seriam destinados às cenas externas; no entanto, entre os microfones disponíveis em nossa configuração, os MKH 416 eram os que suportavam o maior nível de pressão sonora, característica fundamental para a intensa dinâmica da cena. Assim, um microfone foi colocado no boom para acompanhar, junto à câmera, a intrincada mise-en-scène; o outro foi instalado diretamente na segunda câmera, posicionada no fundo do quarto de Soninha.

O deslocamento dos personagens e a movimentação da câmera exigiram extrema habilidade para viabilizar a captação com o direcional operado pelo boom. Como vemos no plano montado, a câmera realiza várias inversões de enquadramento durante a sequência, 
obrigando o operador de microfone a deslocar-se em harmonia com a câmera, ao mesmo tempo em que posiciona o boom corretamente. A primeira inversão de quadro se dá quando Cláudia vem da cozinha para a copa para receber o presente de Teodoro. A câmera contorna a mesa e reenquadra a cena, com pequenas acomodações, e se mantém nessa posição até Teodoro chamar a filha para jantar. Nesse momento, a câmera se reposiciona para receber Soninha. O quadro se mantém até Teodoro desferir o tapa no rosto da filha. O início da caminhada no corredor não é acompanhado pelo microfone, que fica limitado pela câmera à espera da passagem de Cláudia. Após a movimentação da câmera, o boom é rapidamente reposicionado para buscar Teodoro e Soninha, corrigindo o eixo de captação para o interior do quarto onde a cena se desenvolve. A câmera se posiciona na porta do quarto enquanto o operador de microfone, com a ponta do boom dentro do quarto, circunda a câmera, abrindo espaço para o próximo quadro que revelará o corredor com a cozinha ao fundo.

A utilização do boom para a captação da cena se deparou com uma questão insolúvel: para alcançar as ações mais distantes, o boom telescópico precisaria estar aberto; no entanto, para realizar as manobras exigidas pela mise-en-scène nos pequenos espaços, precisaria estar com tamanho reduzido. O resultado é percebido na flagrante perda de eixo da voz de Cláudia na cozinha, quando se dirige à geladeira dizendo "eu vou pegar aqui [...]". O comprimento do boom não permitiu a antecipação do microfone para a manutenção da presença e do brilho da voz. Essa diferença se torna ainda mais perceptível, pois a última palavra da frase “[...] salada", é dita na direção de Teodoro, favorecendo o eixo de captação do microfone, o que torna a voz de Cláudia clara e brilhante.

Durante a captação da primeira tomada, a intensa pressão sonora dos gritos da briga distorceu o sinal gravado. Como grande parte da briga não tem referência de sincronismo labial, a solução para o problema foi encontrada durante a edição de diálogos, a qual mesclou as falas da primeira e da segunda tomada, descartando aquelas com distorção e, ao mesmo tempo, intensificando a tensão da briga, aumentando a quantidade de gritos e xingamentos. $\mathrm{O}$ som da segunda câmera foi usado para os chutes da Soninha e para as falas ouvidas em off.

Para minimizar os ruídos dos objetos de cena, os pés das cadeiras e da mesa foram tratados com feltros autoadesivos e, por baixo da toalha da mesa, foi colocado um tecido acolchoado para amortecer o impacto de pratos e talheres. O ruído provocado pelo deslocamento da equipe, ao acompanhar a movimentação dos personagens, não foi percebido em função da forte projeção de voz dos atores durante a briga. 


\subsubsection{Sequência 22 - Oração na casa do enfermo}

Na sequência 22, um grupo de evangélicos faz uma oração no quarto de um enfermo. Vemos Teodoro e Terezinha participando da reunião. Em coro, a oração é repetida algumas vezes e pontuada por exclamações de louvor. Ao final da sequência, o coro é substituído pelo solo de uma mulher que clama enfaticamente pelo reestabelecimento do doente.
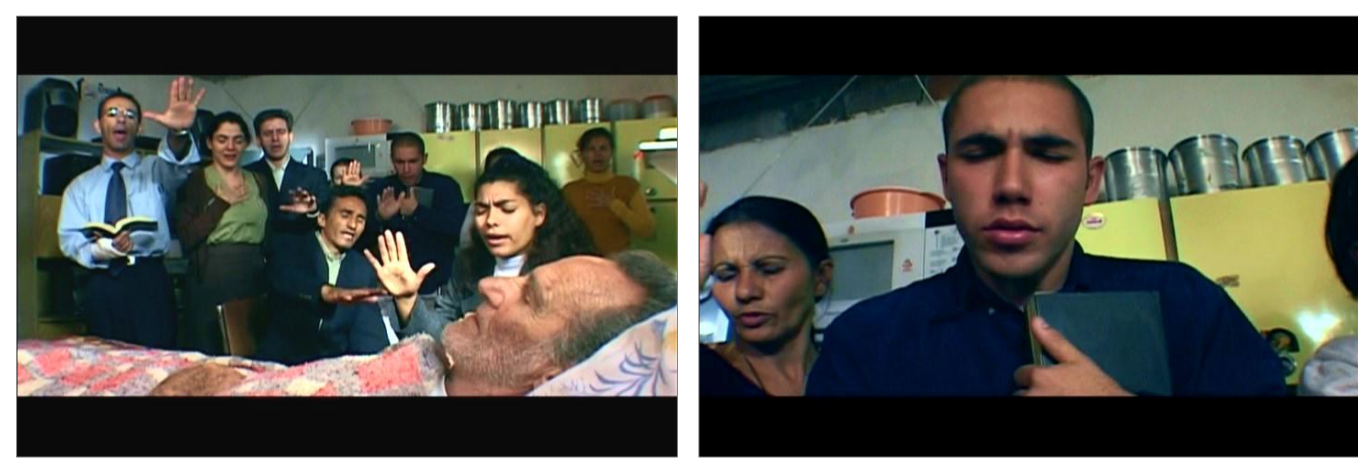

Fotogramas 4 - Sequência 22, Oração na casa do enfermo (CONTRA, 2005).

Com a ação contínua da oração, com diferentes enquadramentos, foram captadas várias tomadas do grupo. Durante a montagem, os planos-sequências foram editados, estruturando a sequência com vários planos curtos.

A locação utilizada era um cômodo com paredes e piso de concreto e com teto baixo, o que resultava numa acústica muito desagradável. A conformação do espaço criava ondas sonoras estacionárias muito perceptíveis que prejudicavam a captação do som direto. $\mathrm{O}$ tratamento acústico da locação foi feito por meio da instalação de grossas mantas de som em todo o piso, o que atenuou significativamente a reverberação e, além disso, eliminou o ruído dos passos provenientes do deslocamento da equipe de câmera durante as tomadas.

A captação foi realizada com o microfone Schoeps. Na tentativa de garantir uma presença homogênea para todo o grupo, foi empregada a cápsula menos direcional que dispúnhamos, a MK4. O principal problema para a captação era a intensa pressão sonora produzida quando todos os participantes oravam em coro, gerando, em alguns momentos, sobremodulação na cápsula do microfone. A forma de atenuar esse problema foi posicionar o microfone o mais distante possível e aproximá-lo rapidamente para obter o detalhe das vozes 
solistas, acompanhando o enquadramento mais fechado da câmera. A aproximação do microfone só podia ser feita depois que o grupo terminava a oração coletiva.

\subsubsection{Sequência 27 - Soninha caminha com a amiga e encontra Marcão}

Na sequência 27, Soninha e a amiga Regininha conversam amenidades enquanto caminham por uma ladeira do bairro. Ao final da descida avistam Marcão. Soninha vai ao encontro dele, que atravessa perigosamente o canal. Estabelecem um joguinho de sedução que culmina com um beijo. Após o beijo, Soninha parte abruptamente, correndo ao longo da avenida. Marcão tenta alcançá-la, mas desiste.
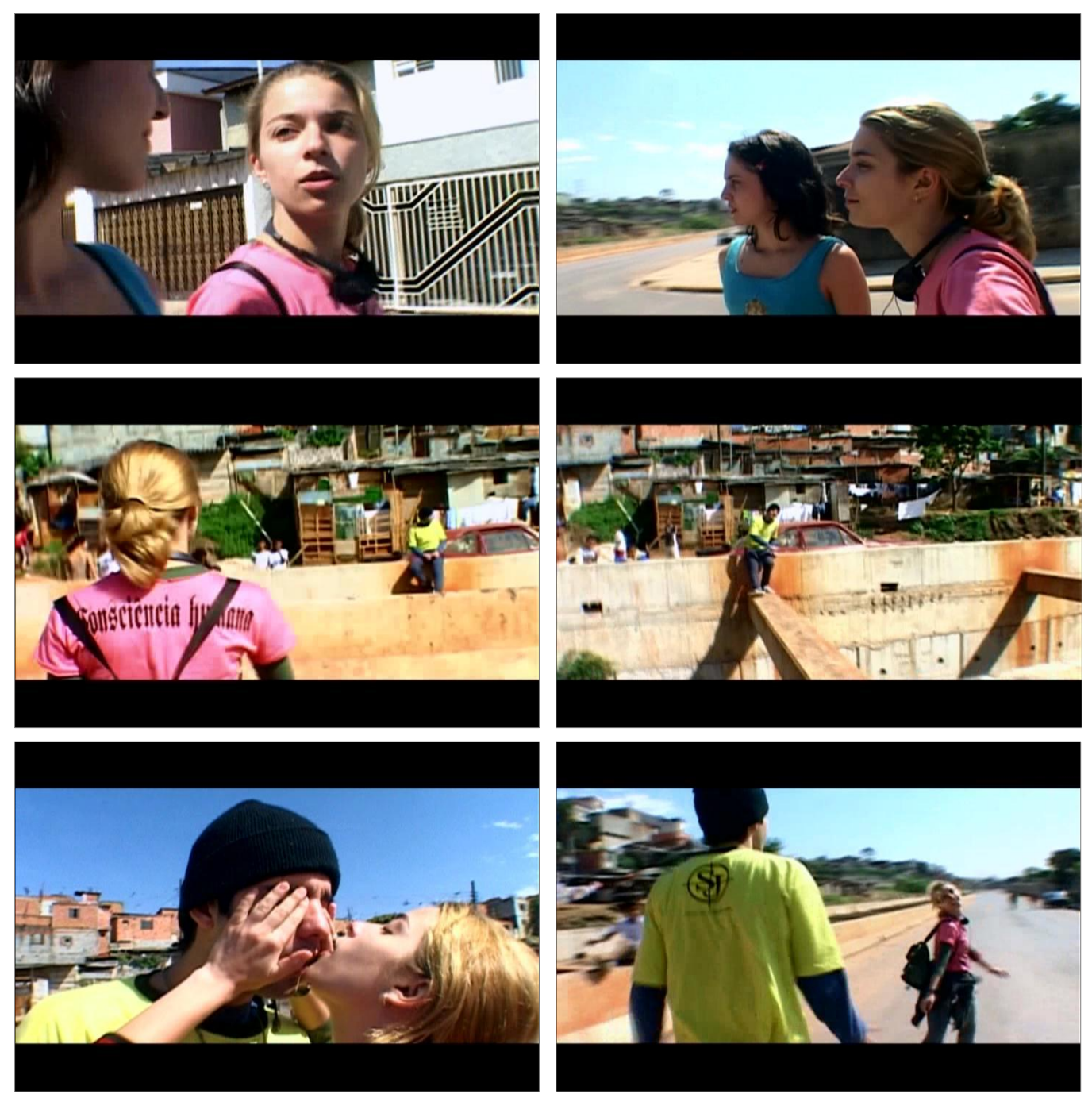

Fotogramas 5 - Sequência 27, Soninha caminha com a amiga e encontra Marcão (CONTRA, 2005). 
A cena foi captada em planos-sequências de longa duração. Para acompanhar a grande caminhada que constituía a cena, foi estruturada uma estratégia de captação num arranjo de alta portabilidade, com o equipamento de som preso ao corpo, numa configuração que normalmente é empregada em realizações documentárias. Nessa sequência, o equipamento foi sustentado pelo microfonista, que monitorava visualmente o áudio captado e regulava o nível de gravação por meio dos controles de ganho do mixer portátil. Realizei a operação do microfone, monitorando auditivamente o sinal captado por meio do fone de ouvido. A equipe de som conectada por intermédio de cabos, se harmonizava com os movimentos realizados pelo operador de câmera, que determinava o deslocamento da equipe de captação. A livre movimentação da câmera exigiu extrema atenção e habilidade da equipe de som, que precisava antecipar-se aos reenquadramentos para manter-se fora de campo e, ao mesmo tempo, garantir o correto posicionamento do microfone.

Foi empregado long shotgun microphone da Sennheiser modelo MKH 816. O intenso nível de ruído ambiente (provocado pela atividade dos moradores, pela passagem de carros e caminhões que trafegavam nas vias próximas) foi determinante na escolha do microfone mais direcional que dispúnhamos. A altíssima capacidade de discriminação dos sons fora de eixo, característica marcante do MKH 816, resultou num recorte definido das vozes que se destacaram do ruído de fundo. Esse destaque da voz, alcançado pelo emprego do supercardioide MKH 816, pode ser comparado ao efeito obtido na fotografia quando se utiliza lentes (as teleobjetivas) com grande distância focal, aproximando os objetos focalizados e achatando a perspectiva da imagem. Essa característica, que determinou a escolha do supercardioide, foi responsável também por uma grande dificuldade percebida logo na primeira tomada: as vozes de Soninha e Marcão, no momento que ficavam se seduzindo na beira do canal, vinham carregadas com um forte chiado, provocado pelo movimento da água do canal. O posicionamento do supercardioide, apontando para baixo, sobre a linha superior de quadro e a proximidade dos atores em relação ao canal favoreciam a captação do ruído da água que escorria no fundo do córrego, assumindo proporções incômodas em relação às vozes. Além disso, a intensidade do ruído variava intensamente à medida que o microfone era reposicionado para a manutenção das vozes no eixo de captação. A alternância de posição entre os atores, os enquadramentos realizados pela câmera e a posição do sol limitavam a movimentação do microfone, de forma a evitar o ruído da água.

A solução encontrada para minimizar a presença da água foi solicitar aos atores que se afastassem ligeiramente da fonte de ruído antes de realizarem o diálogo. Na tomada usada na 
montagem, é perceptível a caminhada de Marcão afastando-se da murada do canal para iniciar o diálogo com Soninha.

No final da sequência, a saída de Soninha, seguida por Marcão, em desabalada carreira inviabilizou a captação de som direto, pois a câmera permanecia fixa e o quadro se tornava extremamente amplo à medida que os atores se afastavam. Foram feitas algumas tentativas de captação de som direto, posicionando-nos na lateral direita de quadro, o que resultou numa captação de péssima qualidade: distante em relação à fonte e com muito ruído de fundo, proveniente da comunidade do outro lado do canal. Como no final da cena os atores estão de costas para a câmera e, portanto, não existe compromisso com o sincronismo labial, a opção adotada foi rodar o som guia durante a captação da imagem, em seguida foi realizada a gravação de várias coberturas de som. Foram gravadas separadamente, a ação de Soninha correndo e rindo para Marcão, os gritos de Marcão chamando por Soninha e, por último, os ruídos produzidos pela corrida de Marcão. A captação dessas coberturas gerou material sonoro que conservou o timbre e a mesma composição do ruído ambiente encontrados no som direto, além de carregar a exata força expressiva da atuação por ter sido gravada in loco e com os atores realmente vivenciando a ação. Durante a edição de diálogos, o som guia foi substituído pelo material das coberturas, o qual mostrou adequação com as imagens e homogeneidade com os demais elementos sonoros da cena.

\subsubsection{Sequência 43 - Waldomiro e Cláudia no quarto do hotel}

Na sequência 43, Cláudia e Waldomiro conversam no quarto do hotel. Cláudia, profundamente indignada, acusa Teodoro pelo assassinato de Júlio enquanto Waldomiro contemporiza. 

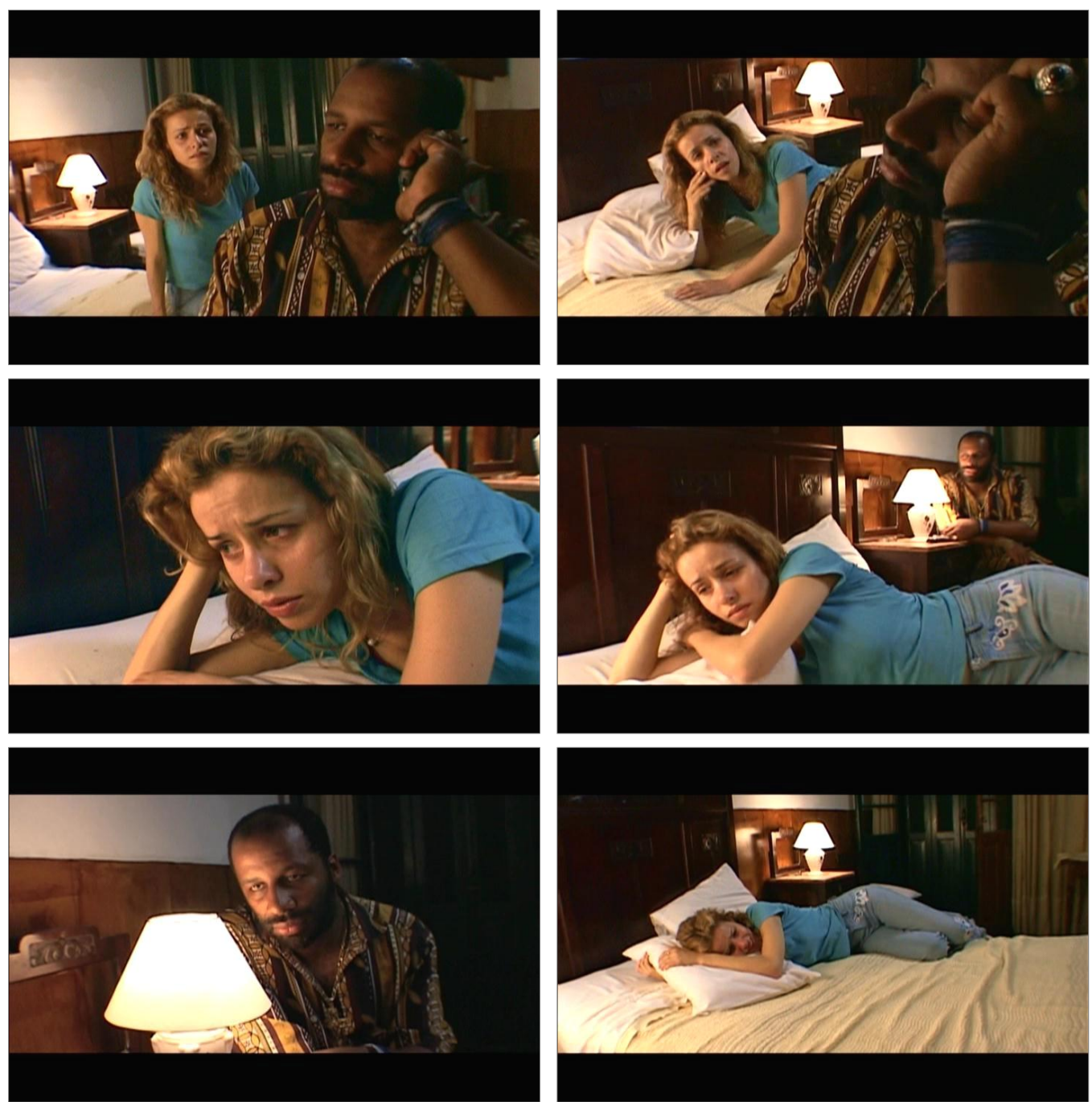

Fotogramas 6 - Sequência 43, Waldomiro e Cláudia no quarto do hotel (CONTRA, 2005).

A sequência 43 é constituída pela sucessão de nove planos. Alguns revelando os dois personagens juntos e outros que enquadram Cláudia e Waldomiro separadamente. A montagem desta sequência pode dar a impressão de uma filmagem convencional, com planos previamente definidos, alternando a presença dos personagens. No entanto, o processo de realização seguiu o mesmo padrão das demais sequências analisadas: diálogo improvisado, captado sempre em plano-sequência e com a câmera assumindo diferentes enquadramentos em cada uma das tomadas: ora privilegiando Cláudia, ora Waldomiro.

Apesar de a distância entre os personagens ser relativamente pequena, a posição assumida por eles em cena (Cláudia deitada na cama, voltada para a frente de quadro e Waldomiro ao fundo) dificultava a captação das vozes com a mesma presença, utilizando um único microfone. Além disso, no diálogo improvisado, as falas se sobrepunham, 
impossibilitando o reposicionamento do microfone para captar cada um dos personagens. Essas condições determinaram a opção pela utilização de dois microfones simultâneos, registrados em pistas independentes. Foram empregados os direcionais MKH 416 da Sennheiser, cada um deles operado por um boom. O espaço do set foi dividido para o posicionamento correto dos microfones. Os booms cobriam áreas pré-definidas, garantindo a presença e a clareza das falas mesmo quando sobrepostas ou em off. O equipamento de som (a mesa de mixagem e o gravador) foi montado próximo à cena, permitindo o disparo da gravação e o monitoramento da captação enquanto um dos booms era operado.

A sequência 43 foi rodada no quarto de um antigo hotel no centro de São Paulo, localizado na Avenida São João, próximo à Praça do Correio. O quarto utilizado como set ficava aos fundos do prédio, com a janela fazendo vista para a Rua Abelardo Pinto, uma pequena rua que liga o Largo do Paissandu ao prédio do Correio Central, o qual, no dia da filmagem, estava em obras. Para atenuar a presença dos ruídos intermitentes provenientes da obra, foi colocada uma dupla camada de mantas de som no lado de fora da janela do quarto, criando um eficiente anteparo acústico. Por sorte, os apartamentos tinham um pequeno terraço que permitia a instalação da estrutura de sustentação das mantas de som.

\subsubsection{Sequência 52 - Teodoro assassina Marcão}

A sequência 52 se inicia com Teodoro em primeiro plano, encostado em um poste. Em perspectiva, vemos uma longa viela e em seu extremo oposto está Marcão, caminhando em direção a Teodoro. 

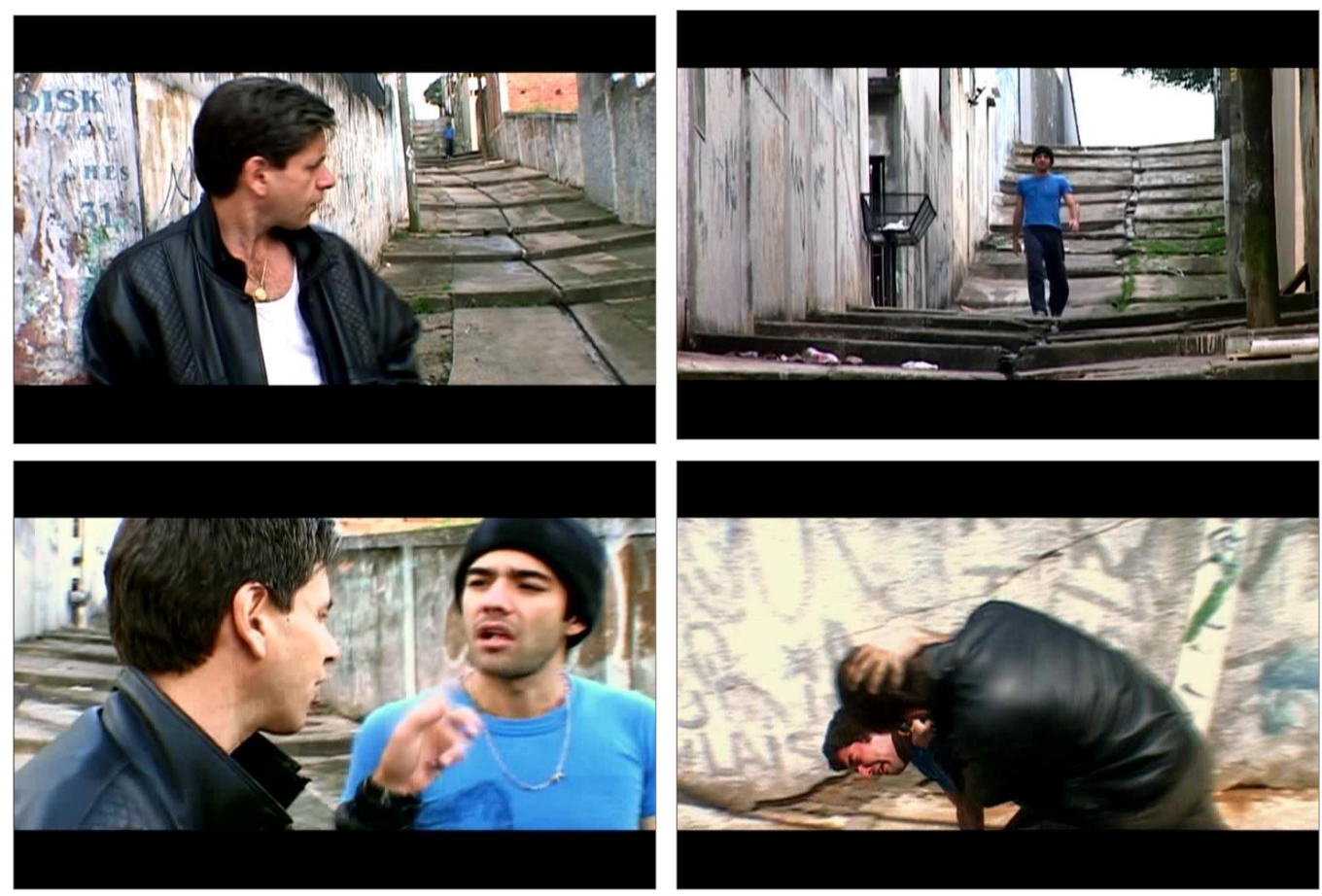

Fotogramas 7 - Sequência 52, Teodoro assassina Marcão (CONTRA, 2005).

Teodoro sobe a viela em direção a Marcão. A câmera revela o encontro dos personagens no ponto intermediário da viela, onde se desenvolve um diálogo curto, culminando com o assassinato de Marcão, que morre com um tiro na cabeça desferido por Teodoro. O diálogo é intenso e carregado de emoção; as vozes assumem entonações extremamente contrastantes, com um grande intervalo dinâmico. A estratégia de captação da cena foi montada com a utilização do supercardioide MKH 816. A escolha desse microfone foi determinada fundamentalmente pela necessidade de registrar as vozes dos personagens totalmente isoladas do ambiente, coerentemente com a representação construída pela imagem que revela apenas os dois personagens. Esse isolamento deveria ser ratificado por um som direto "silencioso", constituído unicamente pela presença das vozes dos personagens. O silêncio do ambiente circundante reforça a verossimilhança da ação, pois denota um espaço ermo, que cria as condições para o matador executar o seu trabalho. A forte discriminação do MKH 816 para os sons fora de eixo foi essencial para captar exclusivamente os sons produzidos pelos personagens. A rejeição dos sons fora do eixo de captação pode ser sentida na perda de presença na fala de Teodoro, quando é empurrado por Marcão no início da briga. Ao se afastar da câmera, percebe-se claramente a "perda de eixo" da voz de Teodoro enquanto é ouvida a fala de Marcão em primeiro plano, mesmo com ele em off. 
A cena foi captada em plano-sequência desde o encontro dos personagens até um pouco antes do tiro. A interrupção da cena nesse momento era necessária para a instalação, no corpo do ator, do dispositivo que cria o efeito do sangue espirrando após o disparo da arma. $\mathrm{Na}$ interrupção da tomada, o microfone era trocado: o sensível MKH 816 era substituído pelo microfone dinâmico Beyer M69. Este microfone de pequeno porte e de baixa sensibilidade se mostrava mais adequado à situação final da cena, que envolvia a captação dos gritos com fortíssima pressão sonora e necessitava de reposicionamento do microfone para favorecer a disposição dos atores em cena. A mudança de posição dos atores, no momento que antecede o tiro, obrigava a inversão da posição de captação, colocando o microfone por baixo da linha inferior de quadro, direcionando o eixo de captação para cima, mas as dimensões do MKH 816 dificultavam esta manobra.

A operação de microfone foi realizada por mim, que monitorava o sinal captado através dos fones de ouvido. O comando do gravador e o controle do nível do áudio foram realizados pelo microfonista, que operava o equipamento na base de trabalho montada no imóvel ao lado direito da viela. A conexão entre o boom e o equipamento de gravação foi estabelecida por meio de longos cabos de microfone, que chegavam ao set pelo muro do imóvel para deixar o campo livre para eventuais enquadramentos realizados pela câmera.

Além das vozes gravadas, o som direto da sequência trazia elementos que contribuíam para a construção da tensão existente na cena. O ruído dos passos durante a caminhada reforçava a ação dos personagens. Durante a luta, os ruídos dos corpos se chocando, o farfalhar das roupas atritadas, os estalos percussivos produzidos pelos pés em contato com o chão intensificam a ação. Após o tiro, restou o ambiente silencioso, entrecortado pela presença sonora de cachorros que latem, ao longe, excitados pelo som dos gritos que antecederam o disparo da arma de fogo. Os ruídos captados pelo som direto têm uma dinâmica clara, que parte de uma situação de tranquilidade, atinge um clímax explosivo para em seguida recuperar parcialmente a característica inicial, contrastada pela presença pontual dos latidos. Essa dinâmica contida no som direto foi potencializada pela edição de som, que reforçou alguns dos ruídos pré-existentes e acrescentou outros (durante a captação da cena não havia o estampido do disparo da arma de fogo). O desenho de som da cena realizado pela pós-produção já estava esboçado nos ruídos registrados pelo som direto. 


\subsection{A REALIZAÇÃO DE ANTÔNIA}

Antônia é o terceiro longa-metragem da diretora Tata Amaral. O filme foi lançado comercialmente em fevereiro de $2007^{94}$, aproximadamente dois anos após o início das atividades de pré-produção, em janeiro de 2005. A proposta de realização do filme estava relacionada com a continuidade do trabalho sobre a representação dos arquétipos femininos desenvolvido nos dois longas-metragens anteriores ${ }^{95}$ da diretora. Em Antônia, o foco de atenção era a representação do arquétipo do nascimento/juventude. A questão central do projeto de realização era apresentar uma visão positiva da periferia paulistana, a partir da perspectiva feminina "da mulher que luta pela sua realização - fiel a si mesma" (informação pessoal) ${ }^{96}$. O universo abordado no filme gira em torno da produção musical do movimento hip-hop.

A principal etapa de captação do filme ocorreu entre o final de fevereiro e o início de abril de 2005. As filmagens foram realizadas principalmente em locações no bairro da Brasilândia, na zona Noroeste da cidade de São Paulo. Uma segunda etapa de captação, com uma semana de duração, foi realizada no mês de março de 2006, após a montagem indicar a necessidade de algumas cenas adicionais. A captação da imagem foi realizada em película cinematográfica no formato super $16 \mathrm{~mm}$, usando câmeras Aaton de fabricação francesa.

A proposta de direção para a realização de Antônia envolvia a captação de apresentações musicais ao vivo, sequências com diálogo e música ocorrendo simultaneamente, atuação improvisada registrada através de longos planos sequências sem prévia marcação de cena. Essas opções de direção geraram situações extremamente desafiadoras, que exigiram cuidadosa preparação e o emprego de estratégias variadas para alcançar o resultado desejado com o total aproveitamento do som direto na trilha sonora finalizada.

\footnotetext{
94 A primeira exibição de Antônia em São Paulo foi em outubro de 2006, durante a $30^{\mathrm{a}}$ Mostra Internacional de Cinema, onde o filme foi premiado como melhor longa-metragem de ficção pelo voto do público, recebendo o Prêmio Petrobras Cultural de Difusão.

${ }^{95}$ Um céu de estrelas (arquétipo da vida) e Através da janela (arquétipo da morte). UM CÉU de estrelas. Direção de Tata Amaral. Casa de Produção: Dist. Riofilme, 1996. (70 min): son., color,; 35 mm. ATRAVÉS da janela. Direção de Tata Amaral.Van Fresnnot: Riofilme, 2000. (82 min): son., color,; $35 \mathrm{~mm}$.

${ }^{96}$ Informação fornecida por Tata Amaral em São Paulo, em 2010.
} 
A produção executiva do longa-metragem foi realizada por Geórgia Costa Araujo, que teve papel determinante na escolha da plataforma de registro de áudio utilizada no filme.

\subsubsection{Aspectos narrativos}

O filme conta a história de quatro jovens mulheres negras, moradoras do bairro da Brasilândia, na zona Norte da cidade de São Paulo, que encaram um cotidiano pobre e violento para realizar o sonho de viver da música rap. Amigas desde a infância, Preta (Negra Li), Barbarah (Leilah Moreno), Lena (Cindy) e Mayah (Quelynah) querem deixar de cantar como backing vocals de um conjunto de rap formado por homens para montar sua própria banda, o grupo Antônia.

Ao longo da narrativa, são seguidos os primeiros passos da formação do grupo musical: o pedido para abrir o show da banda em que fazem backing vocals, o ensaio para a apresentação na Brasilândia e o sucesso da estreia. Porém, a possibilidade de uma carreira promissora por meio da música é frustrada em função de uma sucessão de conflitos, que resultam na separação gradual de cada uma das integrantes do grupo e o abandono do trabalho musical. São acompanhados: o acesso de ciúme de Preta, que rompe a amizade com Mayah; a pressão sofrida por Lena, que cede às exigências de seu companheiro e deixa de cantar após descobrir que está grávida; a prisão de Barbarah, após assassinar o agressor de seu irmão em uma briga de rua; por último, a desistência de Preta, que abandona o trabalho musical e vai à luta pela sobrevivência. Quando as pressões do meio parecem fechar todas as possibilidades, um final otimista e esperançoso é alcançado graças à força e a determinação de Preta, que reúne as antigas amigas e reestrutura o grupo Antônia.

\subsubsection{Condicionantes estéticas}

O início da minha participação em Antônia foi em janeiro de 2005, durante as reuniões de análise técnica. Naquele momento, ainda não existia o roteiro final, com diálogos e cenas detalhadas, o qual, normalmente, orienta essa etapa do trabalho e determina o estabelecimento das necessidades e estratégias de realização de cada departamento. O instrumento que guiou 
nosso trabalho foi uma escaleta ${ }^{97}$ das sequências e uma descrição sumária das cenas, a qual se constituía como um "esqueleto" para o roteiro final. A ousadia da proposta estética apresentada pela diretora foi extremamente impactante, tanto para o diretor de fotografia, Jacob Solitrenic, quanto para mim, responsável pela captação do som direto. Durante a semana de trabalho, buscamos traduzir as premissas defendidas pela direção em procedimentos que pudessem constituir um método de trabalho que orientasse a realização.

A principal premissa defendida pela diretora para a realização do filme "era garantir total liberdade de ação para os atores e atrizes" (informação verbal) ${ }^{98}$. Não poderia existir o habitual engessamento das ações em função das limitações impostas pelo aparato técnico do processo de realização cinematográfica. A câmera e o som deveriam estar a serviço da cena, aproximando-se, assim, do método de captação verificado em alguns documentários, em que a equipe de filmagem segue os acontecimentos sem interferir no desenvolvimento da ação. A opção estética defendida pela direção se expressava na proposição, "vamos correr atrás dos personagens" (informação verbal) ${ }^{99}$. Antônia deveria ser um filme urbano, jovem, com diálogos criados a partir de improvisos, com não-atores atuando sem impostação. A direção enfatizava que o filme deveria criar a impressão de "um olhar que flagra eventos que estão se desenvolvendo" independentemente de uma orientação ou construção externa. Segundo Tata Amaral, "o filme deveria ir atrás de algo que está acontecendo e não colocar a realidade à disposição da realização" (informação verbal) ${ }^{100}$.

A proposição estética da direção se materializava em orientações concretas, tais como: a iluminação de interiores seria realizada apenas por luzes que pudessem ser justificadas pela diegese; nunca seriam empregados refletores para iluminar uma cena, pois, segundo a argumentação da direção, a infraestrutura para a instalação dos equipamentos de luz criaria sempre alguma limitação que tolheria a liberdade para o desenvolvimento da cena. Essa proposta e suas consequentes implicações fotográficas motivaram calorosas discussões entre o diretor de fotografia e a diretora, na tentativa de encontrar soluções que resguardassem os preceitos de direção e não comprometessem o resultado fotográfico do filme.

Em oposição aos filmes em que os eventos encenados ocorrem claramente para a câmera, em Antônia era defendido "um olhar que perseguisse as cenas" que poderia resultar

${ }^{97}$ É um resumo ordenado, em uma escala rigorosa, das cenas e/ou sequências de um filme que é normalmente empregado no processo de desenvolvimento de um roteiro.

${ }^{98}$ Proposição de Tata Amaral durante reunião de análise técnica, em janeiro de 2005.

${ }^{99}$ Idem.

${ }^{100}$ Idem. 
num registro imagético com imperfeições, tais como, perda de foco, quadro com composição irregular, subexposição ou superexposição que seriam incorporadas ao filme, aproximando-o formalmente de algumas obras do campo documentário que assumem expressivamente essas limitações do processo de captação. Influenciada pela realização da vídeoinstalação denominada Jukebox 2: um esboço para Antônia ${ }^{101}$, Tata Amaral propunha que o processo de realização deveria ser tão importante quanto a obra finalizada e defendia que Antônia poderia conter uma instância narrativa que mostrasse o ato de construção da própria ficção: um filme dentro do filme, que revelasse o processo de realização, assumindo, assim, a possibilidade de explicitação dos dispositivos de realização durante as cenas ficcionais de Antônia.

O desafio proposto para a equipe técnica era a "criação de um método de trabalho que possibilitasse a confecção de uma obra que rompesse com a representação tradicional" 102 . Para a imagem, existiam algumas indicações que norteavam essa proposta (câmera na mão, iluminação justificada diegeticamente, enquadramento "imperfeito"); no entanto, em relação ao som direto, não se sabia, exatamente, como essa estética se materializaria. Seria possível assumir baixa inteligibilidade para as vozes? Seriam aceitáveis planos de som sem nenhuma possibilidade de edição em função da existência de intenso ruído de fundo? Quais "impurezas" do som direto seriam incorporadas à trilha sonora final como integrantes da estética de Antônia? Haveria para o som alguma correspondência da "estética documentária" que se vislumbrava para a imagem? Durante o trabalho de análise técnica, não se chegou a conclusões definitivas. Porém, assim como em Contra todos, defendi que mesmo em uma representação não tradicional, que poderia resultar numa visualidade rude, o som direto deveria, ao contrário, ser limpo e inteligível, preservando o padrão de qualidade definido para as representações convencionais. Portanto, o desafio que se impunha à captação em Antônia era garantir o padrão de qualidade convencional "sem criar amarras" que limitassem o processo de realização das cenas.

A busca por uma estética que fugisse da representação tradicional somada à experiência acumulada na realização do documentário VinteDez ${ }^{103}$ definiram para a direção que as personagens principais de Antônia fossem vividas por cantoras que estivessem ligadas ao universo da musica rap ou da chamada "black music". Daí a escolha das jovens, Negra Li,

\footnotetext{
${ }^{101}$ Vídeo instalação realizada em 2004 que reflete sobre a importância do processo de realização em relação à obra finalizada (o processo como obra).

${ }^{102}$ Proposição de Tata Amaral durante reunião de análise técnica, em janeiro de 2005.

${ }^{103}$ Documentário codirigido por Tata Amaral e Francisco Cesar Filho, lançado em 2001, sobre a cultura hip hop da grande São Paulo.
} 
Leilah Moreno, Cindy Mendes e Quelynah que na vida real batalhavam por suas carreiras artísticas. Coerente com a proposta de uma representação carregada de vitalidade, a direção determinou que todas as apresentações musicais previstas na escaleta fossem captadas ao vivo pelo som e pela imagem. Essa opção partia do entendimento que o método convencional empregado na filmagem de apresentações musicais utilizando playback ${ }^{104}$ resulta em cenas que "são originalmente desprovidas de verdade". ${ }^{105}$ Segundo a diretora, mesmo se alcançássemos um resultado convincente em relação ao sincronismo, nunca teríamos a força da interpretação que advém da energia e da pulsação alcançada pelos cantores e músicos quando estão de fato executando uma canção. A opção pelo "ao vivo" foi determinante na configuração técnica montada para o filme e demandou estratégias de captação diferenciadas para a sua realização, conforme será visto adiante.

Para tornar o trabalho do som direto ainda mais complexo, no show de abertura e na sequência Festa de rua na Brasilândia, além da captação ao vivo das músicas, o som da apresentação musical deveria realmente ser ouvido através do sistema de $\mathrm{PA}^{106}$ durante as cenas com diálogo. A amplificação do som do palco era justificada pela direção para garantir que a figuração e os não-atores reagissem mais intensamente, estimulados pela música que seria realmente ouvida durante a tomada da cena. Como técnico de som de Antônia, caberia a mim buscar uma estratégia que garantisse a inteligibilidade dos diálogos, porém desde o início alertei a direção que os planos de som captados nessas circunstâncias teriam baixa "editabilidade", pois as vozes estariam originalmente atreladas aos trechos musicais executados durante a captação e percebidos ao fundo do registro das vozes. Essa opção de direção restringia a montagem dessas cenas.

As cenas seriam captadas exclusivamente por meio de planos-sequências que câmera e o som direto buscariam registrar sem intervenção. A proposta original era radical e não aventava a possibilidade de decupagem convencional das cenas. Na montagem, as sequências

\footnotetext{
104 Playback é a estratégia de realização normalmente empregada para filmagem de cenas com execuções musicais. A música ou canção é previamente gravada e no momento da tomada da cena reproduzida (playback) por meio de um sistema de caixas acústicas, os atores acompanham a gravação, simulando que estão cantando ou tocando enquanto a câmera registra as imagens. Na pósprodução, a sincronização da música pré-gravada com a imagem editada cria a impressão que os personagens estão realmente executando a peça musical ouvida.

${ }^{105}$ Proposição de Tata Amaral durante reunião de análise técnica, janeiro de 2005.

${ }^{106}$ PA é o termo usado para designar o sistema de amplificação eletrônica e as caixas acústicas usadas para reforçar o som em apresentações públicas, deriva do termo inglês public address system ou PA system.
} 
seriam editadas com cortes elípticos no interior do próprio plano (jump cut) ${ }^{107}$. No entanto, ao longo do processo de realização, essa premissa foi flexibilizada, em função das ponderações apresentadas pela montadora Idê Lacreta, que editava o material enquanto filmávamos. Assim, após a primeira semana de filmagem, algumas cenas passaram a ser captadas empregando-se uma decupagem convencional com campo e contracampo e, em algumas situações, planos de detalhes que permitiriam opções de montagem. Porém, o princípio de captar em plano-sequência foi mantido na maioria das cenas realizadas, como pode ser percebido em várias sequências do filme montado, tais como: nas longas caminhadas pelas ruas da Brasilândia, na sequência de abertura, na briga de entre Barbarah e Robinho ou, ainda, na mudança de Preta.

\subsubsection{Pré-produção}

A equipe de som direto do Antônia foi constituída por mim, como técnico de som, por um microfonista e um estagiário. O microfonista Tiago Bittencourt, com quem eu já havia realizado o longa-metragem Cabra cega ${ }^{108}$, foi fundamental no processo de realização, não só pela extrema habilidade na operação do boom, mas também pela participação na definição das estratégias de captação. Os estagiários de som foram: Tatiana Custódio, que integrou a equipe durante as quatro primeiras semanas, e Vinicius Casimiro, que participou durante as duas últimas semanas de trabalho.

As propostas de direção criaram demandas extremamente complexas para a captação do som direto em Antônia: longas caminhadas captadas em plano-sequência, vários personagens em cena com diálogos improvisados, ações sem marcas pré-definidas e, ainda, captação ao vivo das apresentações musicais. Independentemente das possíveis "imperfeições" da imagem, foi definido que o som direto deveria buscar o mesmo padrão de qualidade estabelecido nos filmes convencionais. Portanto, inteligibilidade e "editabilidade" seriam os atributos que norteariam as estratégias de captação com a agilidade e a flexibilidade exigidas pela direção.

\footnotetext{
${ }^{107}$ Jump cut é o termo empregado para designar cortes de imagem realizados no interior de um mesmo plano, suprimindo pequenos intervalos de tempo da ação filmada. A supressão de um curto trecho da ação determina pequenos pulos na imagem que caracterizam esta opção montagem e evidenciam a presença do corte.

${ }^{108}$ CABRA-CEGA. Direção de Toni Venturi. Olhar Imaginário: Dist. Europa Filmes, 2005. (107 min), son., color,; $35 \mathrm{~mm}$.
} 
$\mathrm{Na}$ época, a recém-chegada tecnologia de registro digital multipista não-linear foi decisiva para a captação do som direto em Antônia. A possibilidade de gravação de vários canais em pistas independentes viabilizava a estratégia de captação, que previa a utilização de direcionais e microfones de lapela simultaneamente. Com os equipamentos convencionais, uma ou duas pistas de gravação, a captação com vários canais obriga o técnico de som direto a misturar os sinais dos microfones durante a tomada da cena, endereçando-os a pistas disponíveis no gravador. Para evitar que os microfones endereçados para uma mesma pista somem seus ambientes de fundo ou ruídos de roupa, no caso dos microfones da lapela, os técnicos fazem uma mixagem da cena, abrindo e fechando os canais no momento exato da fala de cada um deles. Esse procedimento é possível em cenas ensaiadas, com texto previamente definido e com o técnico de som operando com precisão os controles do mixer. As longas caminhadas captadas em plano-sequência com os diálogos improvisados exigiam a utilização de vários microfones, mas inviabilizavam a mixagem dos canais durante a tomada, indicando a necessidade da plataforma multipista para solucionar as demandas de realização de Antônia.

A possibilidade de uso de um gravador portátil multipista passou a ser vislumbrada pouco antes do encerramento das atividades de análise técnica, no final de janeiro de 2005, em função das negociações estabelecidas entre a produção executiva e o representante dos equipamentos Aaton no Brasil, o qual dispunha do recém-lançado gravador Cantar-X para locação. Cercada de muita expectativa, a Aaton havia colocado no mercado um gravador de som multipista que incorporava o mesmo diferencial das câmeras cinematográficas da fábrica francesa, com destaque para a notável ergonomia, a resistência e a portabilidade. Respaldado pela excelência técnica dos produtos Aaton, o Cantar-X era anunciado como o novo paradigma para a captação de som direto. No entanto, minha inexperiência com a nova tecnologia e a complexidade dos recursos disponibilizados pelo equipamento geraram certa apreensão em relação à troca de plataforma de gravação. Estimulados pela produtora executiva, que apostava na inovação técnica para responder às demandas de Antônia, iniciamos um processo de experimentação e treinamento com o gravador. Foram quinze dias de trabalho intenso, antes das filmagens, para entender o funcionamento e desvendar as rotinas de configuração que, após certo tempo, se mostraram lógicas e amigáveis, tornando a operação do equipamento ágil e prática. Percebemos que a qualidade técnica superava as expectativas que e os recursos presentes faziam do Cantar-X uma poderosa ferramenta para os desafios propostos para a realização do Antônia. 
O Cantar-X (Foto 17) é uma plataforma digital portátil multipista não-linear que grava os arquivos de som em disco rígido em até oito pistas independentes. Ele possui nove potenciômetros, rotativos na parte superior, que individualmente controlam o ganho das nove entradas analógicas: cinco entradas para sinal de microfone e quatro entradas para sinal de linha.

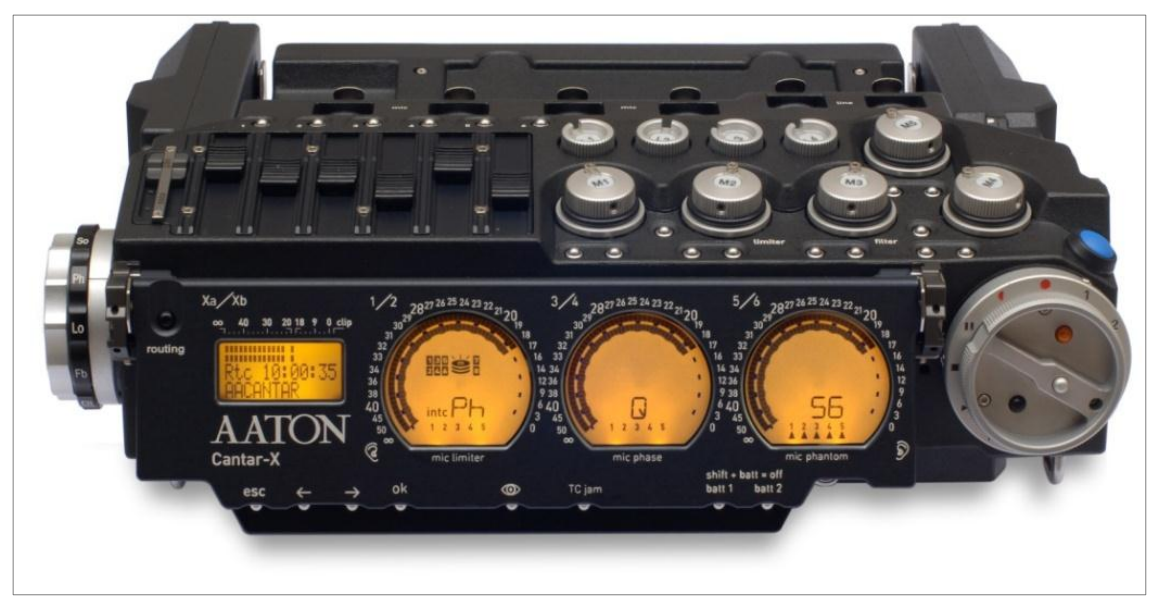

Foto 17 - Vista frontal superior do gravador Cantar-X.

As dimensões e o posicionamento dos potenciômetros permitem acesso fácil e controle de volume preciso, mesmo com o equipamento pendurado no ombro em cenas com intenso deslocamento. O painel frontal com articulação basculante, onde estão localizados os módulos de monitoração, possibilita a fácil leitura dos níveis de gravação de cada uma das pistas e das informações de configuração do equipamento, tanto trabalhando num carrinho de som quanto no ombro. O fornecimento de energia é feito por duas baterias laterais que protegem o disco rígido e garantem excelente autonomia para o gravador. Uma máquina com altíssima qualidade sonora que permite a utilização de até cinco microfones ligados diretamente ao gravador e, também, sinais de linha registrados em oito pistas. Os excelentes pré-amplificadores de microfone e a prática estrutura para o roteamento de sinais no Cantar-X dispensam o uso de um mixer, permitindo uma configuração compacta com alta portabilidade.

A definição do Cantar-X como a plataforma para o registro do som direto em Antônia permitiu o detalhamento das estratégias de trabalho. Em linhas grais, a captação de som seria realizada, sempre que necessária, com a utilização simultânea de microfones direcionais e microfones de lapela com transmissão via rádio. Foi definido que seriam quatro sistemas de microfones de lapela via rádio, disponíveis durante toda a filmagem, potencializando, dessa 
forma, o uso do gravador que permitia até cinco microfones conectados diretamente. Foram locados dois sistemas da Lectrosonics, modelo 190, e dois sistemas da Sennheiser, modelos SK50 e SK250. Cada sistema sem fio possuía duas cápsulas com características particulares que se destinavam às diferentes condições de captação. O trabalho desenvolvido na préprodução sistematizou as necessidades do som direto junto a cada departamento e definiu as linhas gerais para a captação que podem ser resumidas nos seguintes tópicos:

- Definição e preparação das locações. A escolha e a preparação das locações para Antônia foram um processo complexo. A grande quantidade de locações e suas constituições particulares determinaram a aplicação de estratégias variadas para alcançar as condições acústicas adequadas e garantir o controle de fontes sonoras indesejadas. As casas dos personagens na Brasilândia deveriam ter a cidade de São Paulo como paisagem de fundo, portanto, a escolha dessas locações foi determinada pelas necessidades da imagem. A alta densidade populacional e a configuração topográfica do bairro resultavam num ambiente ruidoso, com a presença de sons gerados a longas distâncias. A principal questão para a escolha de uma locação na Brasilândia era a possibilidade de controle sobre as fontes de ruído próximas, como: cães, crianças, oficinas mecânicas, serralherias, marcenarias, entre outros. A produção de set seria responsável pela remoção de animais e o controle de atividades domésticas e profissionais dos vizinhos durante a filmagem. As locações na Brasilândia que tinham maior incidência na escaleta receberiam intervenção acústica permanente com a instalação da tenda árabe, como pode ser visto na Foto 18, além da contribuição da direção de arte por meio de cortinas e móveis que ajudassem na absorção sonora. As demais locações (o ginásio para a sequência do Ensaio, a casa para a Festa de burguês, o bar Coppola Music para as sequências das apresentações musicais do desfalcado grupo Antônia) receberiam tratamento acústico por meio da instalação de mantas de som nos dias de filmagem. Como as locações apresentavam dimensões e características acústicas muito diferentes entre si, foram estabelecidos três conjuntos denominados "kits mantas de som", com quantidades de mantas e acessórios adequadas para as necessidades de cada espaço. A partir do cronograma de filmagem a sua utilização foi mapeada até o final das filmagens. 


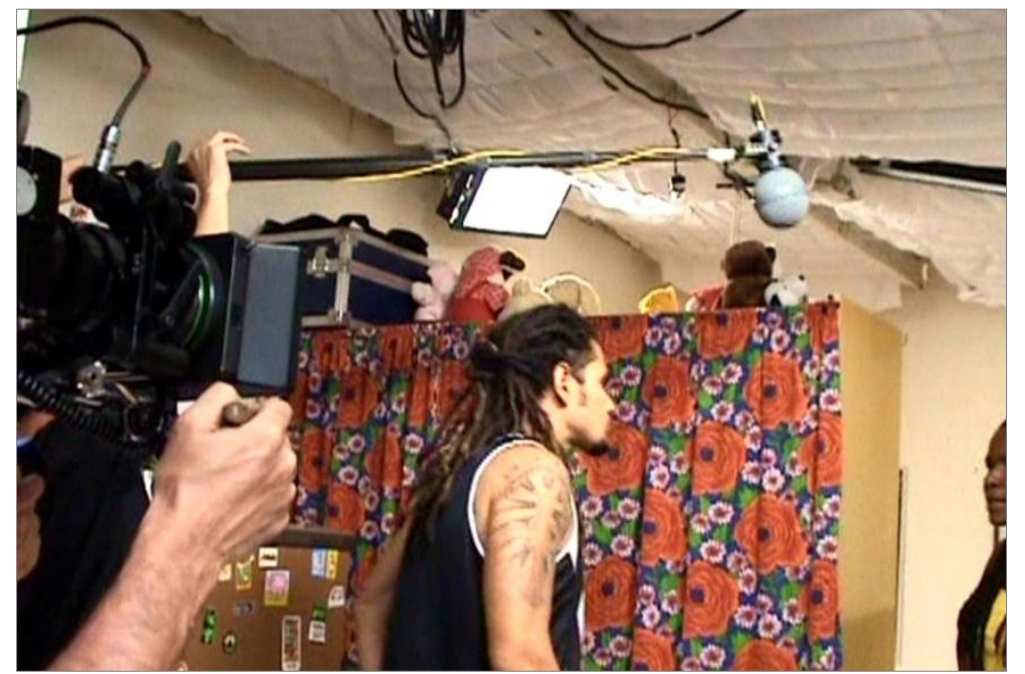

Foto 18 - Tenda árabe cobrindo o teto da locação casa de JP, tomada de cena sequência 51 - Lena e Maionezi brigam. Frame extraído do making of do filme Antônia (2007).

- Figurino das personagens. A previsão de uso constante dos microfones de lapela sem fio determinava que o figurino e os adereços das protagonistas fossem silenciosos e que permitissem a ocultação do radiotransmissor. Sabendo da tendência para roupas justas e exíguas, foram previstas alternativas que garantissem a instalação do equipamento junto ao corpo das personagens, tais como: a utilização de moletons amarrados na cintura ou pequenas bolsas, que abrigassem os transmissores dos microfones, carregadas junto ao corpo.

- Preparação dos veículos de cena. Como as cenas com veículos em movimento seriam realizadas com os carros em real funcionamento, foram estabelecidas as condições para a realização dessas cenas. A despeito de parecerem velhos, os carros deveriam ter perfeitas condições mecânicas, além de motor, escapamento e suspensão silenciosos. O percurso para a tomada deveria ser plano, com asfalto liso, e a velocidade durante a cena deveria ser baixa. Além disso, os veículos receberiam um tratamento interno com a instalação de espumas e mantas de som para reduzir as trepidações e diminuir a reverberação.

- Captação das apresentações musicais. Com a escolha do Cantar-X estabelecemos que as apresentações musicais com até oito fontes sonoras simultâneas seriam captadas e registradas pela equipe de som direto. As apresentações musicais com mais de oito fontes simultâneas seriam registradas por uma equipe especializada na gravação de shows ao vivo. Foram criadas as 
categorias shows pequenos e shows grandes, as quais sistematizavam as duas configurações de realização. Os shows pequenos da sequência 21 (Festa de burguês / Killing me softly), da sequência 31 (Coppola Music / Ela é demais) e da sequência 37 (Coppola Music / Como uma onda no mar) seriam registrados pela equipe de som direto, utilizando os recursos do Cantar-X. Os shows grandes da sequência 2 (Show de abertura), da sequência 15 (Festa de rua), da sequência 54 (Show presídio) e da sequência 55 (Show final) seriam registrados pelo técnico de som Roberto Marques, o Zorro, em seu estúdio móvel em até 64 pistas independentes. Além da gravação das fontes sonoras do palco, a utilização do estúdio móvel garantiria a captação e o registro das reações da plateia e a ambiência do show em pistas separadas que na pós-produção seriam utilizadas para criar o surround sonoro da cena.

\subsubsection{Estratégias de captação}

Os procedimentos de captação do som direto foram norteados pela premissa central de realização de Antônia: "garantir total liberdade de ação para os atores e as atrizes" (informação verbal) ${ }^{109}$. As profundas diferenças de mise-en-scène entre as diferentes sequências determinaram a adoção de estratégias variadas com configurações particulares que atendessem às características de cada cena. A busca por uma representação sonora que conservasse a perspectiva acústica dos ambientes determinou que utilizássemos, em todas as cenas, microfones direcionais operados pelo boom, mesmo quando a captação principal da ação era realizada por microfones de lapela sem fio.

A captação dos diálogos nas cenas com caminhadas pelas ruas da Brasilândia exigiu o emprego de uma configuração de alta portabilidade, com o gravador Cantar-X preso ao corpo, eu acompanhava o deslocamento da cena, caminhando com o microfonista que operava $o$ microfone direcional sustentado pelo boom. Na maioria das vezes, o sinal do microfone direcional era enviado ao gravador via cabo, como pode ser visto na Foto 19. Nessas situações, normalmente foi empregada a captação simultânea do microfone direcional operado pelo boom e dos microfones de lapela para garantir maior presença das vozes.

\footnotetext{
${ }^{109}$ Proposição de Tata Amaral durante reunião de análise técnica, em janeiro de 2005.
} 


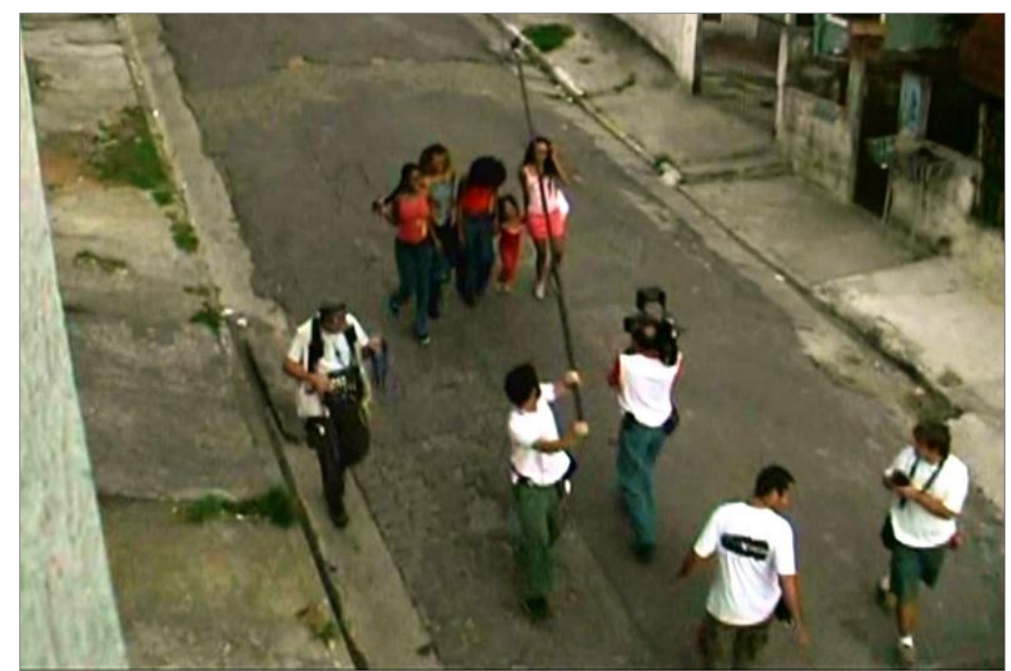

Foto 19 - Tomada de cena da sequência 14 - Caminhada para a festa de rua (primeira filmagem). Frame extraído do making of do filme Antônia (2007).

Essa configuração foi utilizada em sequências em que participavam até quatro personagens ao mesmo tempo, limite determinado pelo número de lapelas sem fio disponíveis e pela quantidade de entradas de microfone existentes no Cantar-X. Entre as sequências nas quais foi empregada essa estratégia, podemos citar: sequência 16 (Caminhada de volta para casa. Preta e Barbarah), sequência 23 (Na Brasilândia, caminhada para casa. Preta, Barbarah e Lena), sequência 33 (Caminhada Brasilândia / Provocação Robinho), entre outras. Uma variação da estratégia descrita anteriormente foi empregada na sequência 13 (Mudança de Preta). Esta sequência foi captada como um longuíssimo plano-sequência que iniciava dentro da casa de Preta, durante os preparativos para a mudança, e terminava, depois de extensa caminhada, com o grupo de amigos descendo a ladeira após contornar a esquina em direção à casa de Barbarah. Em função do número de participantes optamos por captar a cena com dois microfones direcionais sustentados por booms. O microfone operado pelo microfonista enviava o sinal de áudio para o gravador através de um sistema de radiotransmissão; o microfone operado por mim estava conectado ao gravador via cabo. Para tentar garantir a presença homogênea dos seis personagens, foram estabelecidas zonas de captação para cada um dos microfones.

Os direcionais operados por boom nas externas foram os microfones Sennheiser MKH 416, com os acessórios para proteção contra vento. Esses short shotgun se mostravam mais adequados aos rápidos ajustes de posicionamento, necessários para garantir o eixo de captação das várias personagens, do que os direcionais mais longos. Nas cenas interiores, foram usados 
microfones direcionais menos restritivos. Foram empregados os microfones da Schoeps com cápsulas MK41.

Nas cenas sem deslocamento, foi empregada a configuração de menor portabilidade com o gravador e os acessórios dispostos sobre o carrinho de som, como pode ser visto na Foto 20.

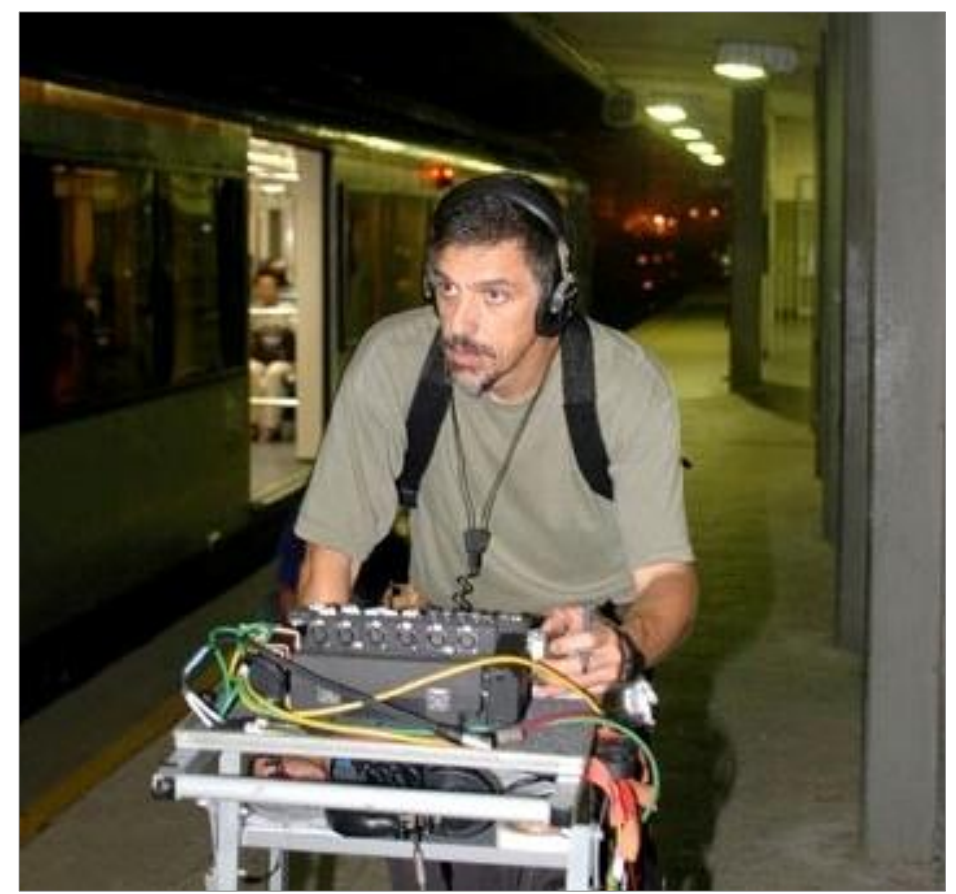

Foto 20 - Tomada de cena da sequência 8 - Espera do trem na estação.

Nos shows pequenos, durante a execução das canções, as vozes das cantoras foram captadas pelos microfones dinâmicos, sustentados pelos pedestais, que são vistos em quadro. Esses microfones se conectavam diretamente ao gravador e eram registrados em pistas independentes. O acompanhamento musical executado pelo teclado era registrado estereofonicamente em duas pistas do Cantar-X; os sinais de áudio do teclado eram enviados por cabos e acessavam o gravador através das entradas de linha. A captação da ambiência da cena, realizada simultaneamente à execução da canção, era feita por um microfone estereofônico ou um microfone monofônico, dependendo disponibilidade de entradas do gravador.

A seguir, serão detalhados os procedimentos de captação de algumas sequências de Antônia, apontando as principais dificuldades de realização e avaliando os resultados obtidos. 
Essas sequências representam um painel diversificado das situações encontradas, exemplificando as principais estratégias empregadas.

\subsubsection{Sequência 03 - Na van pedido para abrir o show do grupo O Poder}

A sequência 03 acontece no interior da van que, após o show de abertura, transporta o grupo O Poder. No veículo estão os sete integrantes da banda: Preta, Barbarah, DJ Anjo, Dante, Lena, Mayah e DJ Cocão. Durante o trajeto, eles discutem caoticamente questões relativas à apresentação, até o momento em que Mayah pede que as moças façam a abertura do próximo show do grupo, que será na Brasilândia, com uma composição delas. Quando descem da van na estação de trem, ficamos sabendo que o pedido foi aceito. 

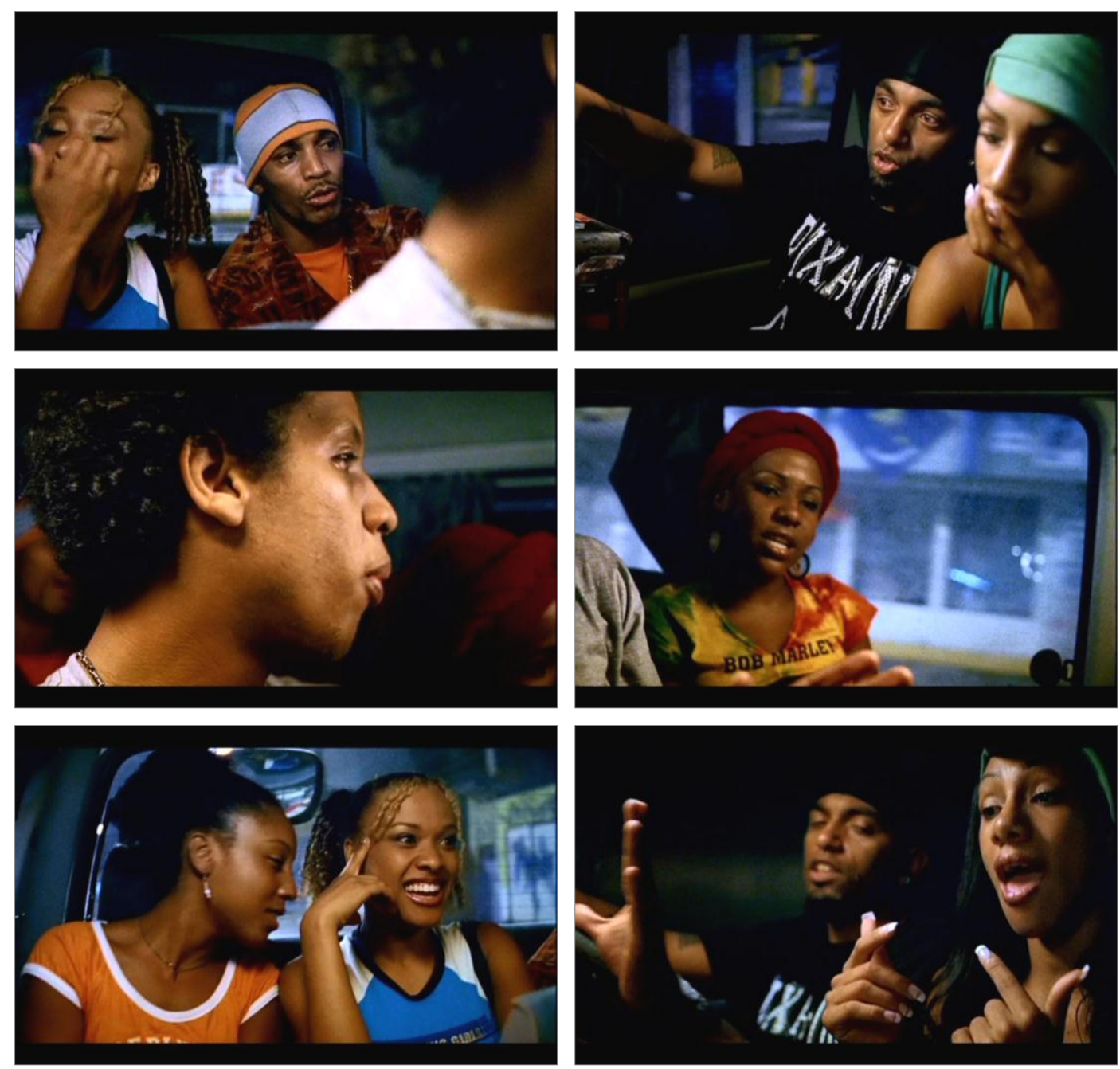

Fotogramas 8 - Sequência 03, Na van pedido para abrir o show do grupo O Poder, (ANTÔNIA, 2007).

$\mathrm{O}$ veículo em funcionamento e com sete personagens interagindo com texto improvisado tornava extremamente complexa a captação do som direto da sequência. A única marcação pré-definida de texto era a fala de Mayah, que faria o pedido para a abertura do show. A disposição dos personagens no interior do veículo e a atuação improvisada inviabilizavam a utilização de um único microfone operado por boom para cobrir toda a ação, não haveria tempo e nem espaço para correção da posição do microfone para captar, por exemplo, a fala de DJ Anjo, que estava posicionado ao fundo da van, seguida de uma fala de DJ Cocão, que estava sentado no banco da frente.

A proposta inicial da direção era a captação da cena em um único plano-sequência, que iniciaria no interior do camarim da casa de show e acompanharia toda a caminhada do grupo com a entrada na van e, finalmente, o diálogo durante o trajeto até a estação de trem. Percebida a inviabilidade técnica, tanto para o som quanto para a imagem, optamos por 
desmembrar a ação em dois planos-sequências. Assim, durante a tomada, a sequência se iniciava com os personagens já posicionados no interior do veículo em movimento.

A captação de som da cena foi realizada por meio de uma estratégia mista que empregou simultaneamente quatro microfones de lapela com fio, afixados no teto da van, e um microfone cardioide aberto suspenso pelo boom. Foi usado o microfone direcional da Schoeps CMC6 com a cápsula MK4, da mesma forma como citado anteriormente, com o acessório de articulação Swivel GVC (ver Foto 16), que diminuiria o comprimento do microfone e permitiria movimentá-lo no reduzido espaço que havia entre a linha superior de quadro e o teto do veículo. Dois microfones de lapela cobriam a área dos assentos traseiros onde estavam Preta, Barbarah e DJ Anjo; e outros dois cobriam a parte dianteira onde estavam Mayah e DJ Cocão. Foram coladas, internamente no teto da van, pequenas placas retangulares de acrílico, nas quais foram afixadas as cápsulas dos microfones de lapela. As placas de acrílico criam uma superfície reflexiva que modifica o padrão de captação dos microfones de lapela, simulando o comportamento de um microfone boundary layer $^{110}$. Os lapelas ficaram responsáveis pelas zonas de captação extremas onde o direcional teria maior dificuldade chegar.

A instalação dos microfones de lapela foi realizada na tarde que antecedeu a filmagem, enquanto aguardávamos a finalização dos preparativos para rodar a sequência 2 (Show de abertura). Durante a preparação, além dos microfones de lapela no teto, o assoalho da van foi forrado com mantas de som e todos os vidros das janelas foram "calçados" com borracha. Como estabelecido durante a análise técnica, a velocidade do veículo e a rotação do motor seriam baixas, garantindo o menor nível de ruído possível.

Para a captação da cena, o fotógrafo se instalou, com a câmera na mão, no espaço que dá acesso à parte traseira do veículo, entre os bancos e a porta de correr da van. Dessa posição, ele corrigia o enquadramento por meio de movimentos laterais, dividindo o espaço com o assistente de câmera.

\footnotetext{
${ }^{110} \mathrm{O}$ boundary layer microphone é um microfone que apresenta sensibilidade para altas e médias frequências e tem padrão de captação semiesférico independente do posicionamento da cápsula em relação à fonte sonora. $\mathrm{O}$ funcionamento desse microfone é baseado no princípio físico da duplicação da pressão sonora do campo direto ao longo de uma superfície refletora. A cápsula que é colocada diretamente sobre uma superfície refletora irá responder com intensidade duas vezes maior que uma cápsula que está suspensa no meio do campo acústico direto. Como a resposta para o campo acústico difuso permanece inalterada, é acentuada a clareza na captação de uma fonte sonora a uma determinada distância.
} 
Posicionei-me de joelhos no assento dianteiro, ao lado do motorista, com o corpo voltado para trás e o gravador colocado sobre o banco. A operação de boom era restrita e a vara não podia estar muito aberta para alcançar os personagens no fundo da van, pois isso impossibilitava o posicionamento do microfone para os personagens que estavam sentados na frente. As opções assumidas foram: deixar o boom com pequena extensão e garantir a captação dos quatro personagens que estavam mais próximos à câmera, coerente com a perspectiva da imagem. O microfone direcional acompanhava o olhar da câmera, priorizando o eixo de captação para o personagem que era visto em quadro. Os demais que falavam simultaneamente eram captados pelos microfones de lapela. A direcionalidade mais aberta do microfone foi importante para garantir a presença homogênea da voz dos quatro personagens. Durante a captação, monitorei auditivamente apenas o microfone direcional, vivenciando a difícil questão que cerca a metodologia multipista: como monitorar todas as fontes que estão sendo captadas simultaneamente? $\mathrm{Na}$ medida em que é impossível avaliar a qualidade de captação de cada uma das fontes, ouvindo-as misturadas, a opção é eleger uma única pista. $\mathrm{O}$ gravador Cantar-X possibilita um recurso extremamente útil que permite configurar a monitoração, pré-selecionando as pistas ou canais que se deseja ouvir. Essa seleção é acessada durante a gravação por meio de um comando rotativo posicionado na lateral do gravador, porém é necessário ter livre, pelo menos, uma das mãos para realizar esta operação. Nessa cena, a solução foi monitorar o aéreo durante as tomadas e realizar uma checagem rápida das outras pistas nos intervalos entre as tomadas.

\subsubsection{Sequência 12 - Ensaio do Antônia no ginásio}

Na sequência 13, acompanhamos o ensaio das meninas para a estreia do grupo Antônia. A sequência se inicia com Lena chegando atrasada no ginásio onde as amigas a esperam. As meninas organizam a coreografia, dançam e cantam ao som da base musical reproduzida pelo aparelho de $\mathrm{CD}$. Acompanhando o ensaio, há Emilia, que se diverte descontraidamente. Elas conversam sobre o figurino, revelando a intenção de usar roupas ousadas e sensuais para a apresentação. A montagem fragmentada acelera a cena, acentuando a descontração do encontro.

A sequência muda de tom quando Barbarah reforça o convite para que Preta e Emília se mudem para casa dela. 

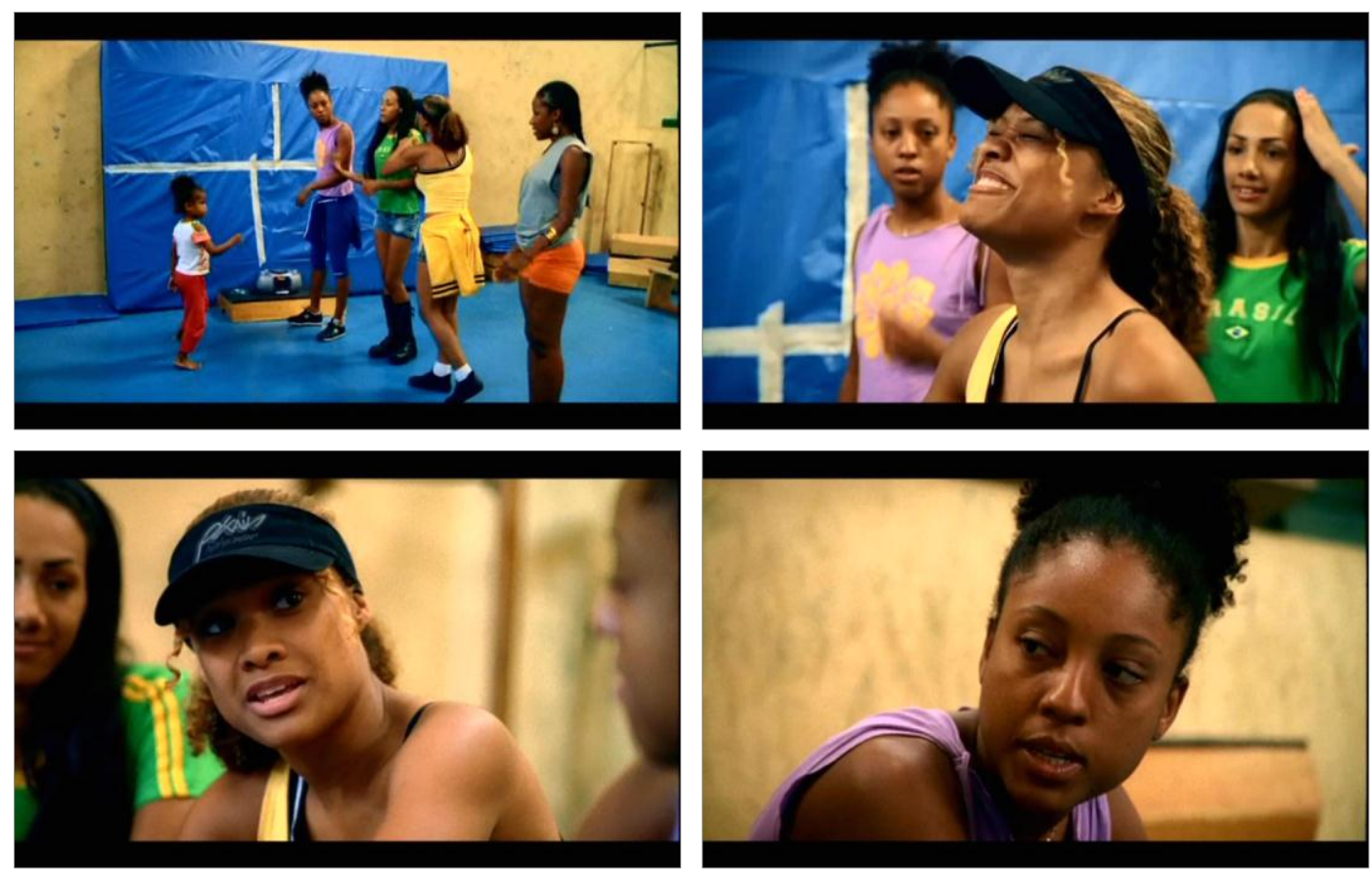

Fotogramas 9 - Sequência 12, Ensaio do Antônia no ginásio (ANTÔNIA, 2007).

A cena foi realizada no ginásio de um conjunto poliesportivo da prefeitura de São Paulo, localizado no bairro da Brasilândia. Durante a pré-produção foi observada a alta reverberação do ginásio e o intenso nível de ruído externo, o que dificultaria a captação de som da cena. Questões de produção foram imperativas na definição desta locação. O som direto teria que buscar soluções técnicas que viabilizassem a captação.

O modo usual para a redução da reverberação por meio da construção de um teto de mantas de som suspenso por um grid estava triplamente descartado: em função das restrições orçamentárias, das necessidades da fotografia que utilizaria as luzes do próprio ginásio para iluminar a cena e, ainda, pela liberdade de enquadramento desejada pela direção. O tratamento acústico possível foi a instalação de mantas de som suspensas por tripés, formando um varal de mantas, cobrindo a única parede que não seria enquadrada às costas da câmera. Para baixar a reverberação, foi solicitada a colaboração da direção de arte, que utilizou objetos cênicos que auxiliavam na absorção do som (colchões, tatames e tecidos). O nível de ruído externo era muito variável e sem controle. A localização do ginásio próximo a ruas de grande movimento, inclusive rota de ônibus, gerava forte descontinuidade no ambiente sonoro de fundo.

A estratégia de captação adotada para contornar as condições acústicas desfavoráveis empregou quatro microfones de lapela via rádio, um para cada personagem, gravados em 
pistas separadas. Simultaneamente foi empregado o microfone direcional da Shoeps MK41 (cardioide mais fechado), operado por boom, para restaurar um pouco da naturalidade das vozes captadas com os microfones lapelas. Como este direcional é menos sensível ao campo sonoro difuso, quando comparado ao Sennheiser MKH 416, ele se tornava a melhor opção de microfone direcional. Foram utilizadas as cinco entradas de microfones disponíveis no Cantar-X.

Os microfones de lapela restringiram, em parte, a captação da reverberação e dos ruídos de fundo, permitindo que as vozes tivessem maior presença e clareza, aspectos fundamentais para aumentar a inteligibilidade das falas. A opção pelo microfone direcional, completando a estratégia, objetivou municiar a pós-produção com material que permitisse a restituição de uma sonoridade mais natural para as vozes, dosando a espacialidade do ambiente na mixagem coerente com a proposta estética do filme.

Em espaços muito reverberantes, a monitoração do microfone direcional e dos microfones de lapela feita por uma única pessoa, mesmo que alternadamente, é uma atividade que embaralha a referência auditiva. $\mathrm{O}$ contraste entre as sonoridades disponibilizadas por essas diferentes classes de microfones confunde a percepção do técnico, criando uma sensação enganosa, na qual a sonoridade do direcional parece estar carregada com uma quantidade ainda maior de reverberação, enquanto o som do microfone de lapela parece ser extremamente "seco" e antinatural, o que dificulta a avaliação da qualidade do material captado. Para preservar a referência auditiva e a possibilidade de julgamento do material, optoamos por dividir a monitoração por classes de microfones. Durante as tomadas dessa sequência a monitoração auditiva do microfone direcional foi realizada exclusivamente pelo microfonista, enquanto os microfones de lapela foram individualmente monitorados por mim, com o emprego do comando rotativo do Cantar-X.

A realização da cena envolveu ainda a execução de uma base rítmica que marcava o andamento musical para guiar a ação das personagens durante o ensaio. O caráter diegético da música é justificado pela presença do CD player, trazido por Lena, que é ligado em cena por Barbarah antes de começarmos a ouvi-la na narrativa. Durante as tomadas, a base musical foi reproduzida a partir de um laptop operado pelo técnico de som e amplificada por uma caixa acústica posicionada fora de quadro. O volume de reprodução da música e o posicionamento da caixa acústica eram as variáveis que precisavam ser controladas para garantir que as cantoras fossem devidamente estimuladas e, ao mesmo tempo, a captação das vozes não fosse prejudicada pelo volume excessivo da base musical. Além de ser gravada ao fundo das vozes, 
pelo "vazamento" em cada um dos microfones, a base musical foi simultaneamente transmitida via cabo para uma entrada de linha do Cantar-X, onde foi registrada em pista separada.

\subsubsection{Sequência 14 - Caminhada para a festa de rua}

É final de tarde, num cruzamento das ruas da Brasilândia, quando as meninas se encontram e caminham eufóricas para o show de estreia do Antônia. No início da sequência, com a típica paisagem da Brasilândia ao fundo, vemos ao longe Preta e Barbarah, caminhando juntas, Mayah segue na direção delas quando chega Lena, completando o quarteto.
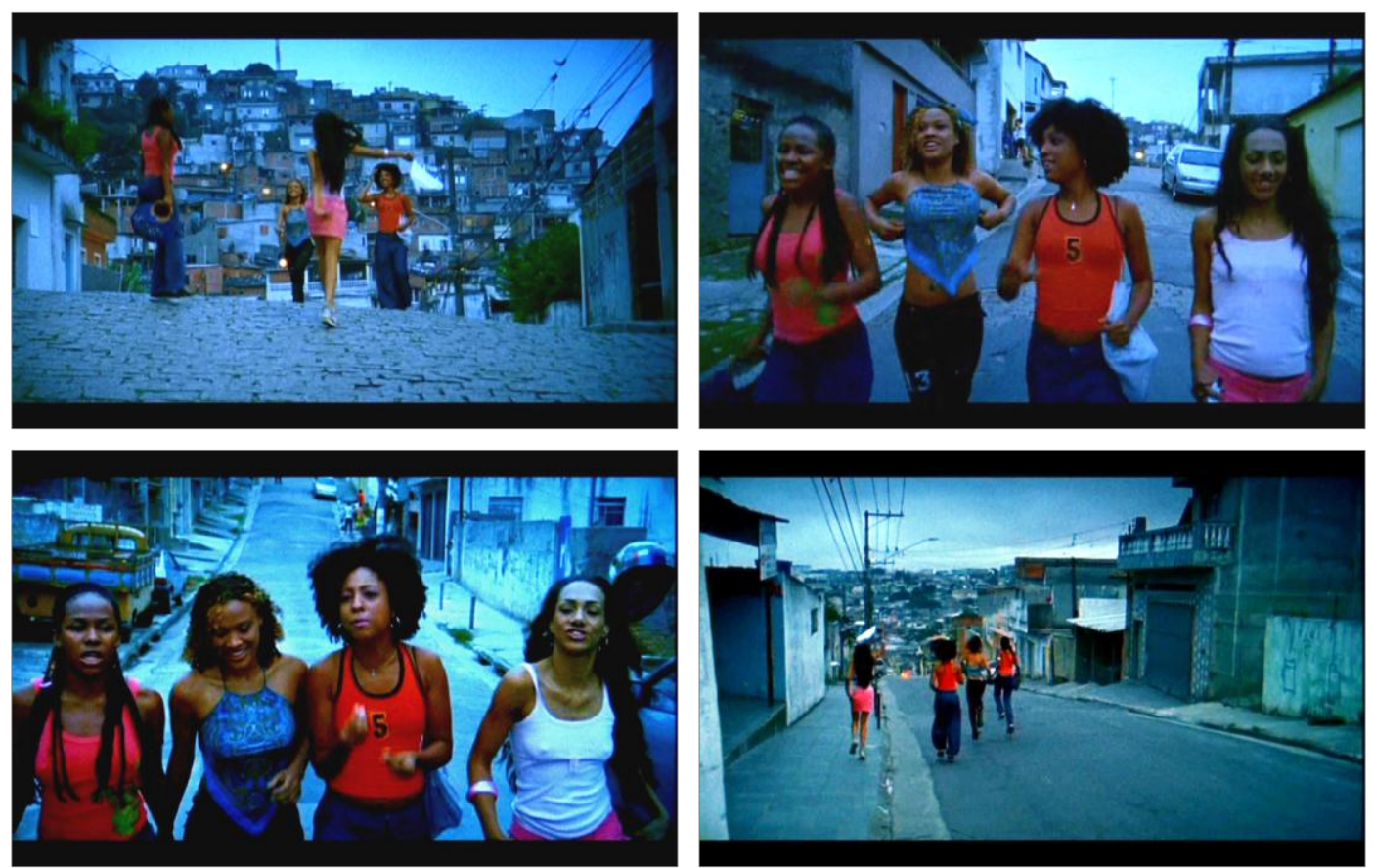

Fotogramas 10 - Sequência 14, Caminhada para a festa de rua (ANTÔNIA, 2007).

O encontro é animado, ouvimos a distância os comentários de Barbarah a respeito da roupa de Mayah. Descem a rua caminhando em direção à câmera que passa a acompanhá-las ao longo de todo o trajeto. A expectativa e a alegria com a estreia são contagiantes. A vitalidade da cena é potencializada por dois jump cuts que abreviam a caminhada. No final da sequência, vemos as meninas de costas, descendo a ladeira, e a música ouvida ao fundo 
durante parte da caminhada se torna mais presente, introduzindo a próxima sequência: Festa de rua.

Coerente com a proposta geral de realização de Antônia, a cena foi captada por meio de um longo plano-sequência. A partir de uma posição fixa inicial, a câmera operada na mão e o som direto numa configuração de alta portabilidade acompanharam, sempre frontalmente, a caminhada das personagens ao longo de toda a rua. Próximo ao final do quarteirão, as personagens ultrapassavam a câmera que corrigia o enquadramento, acompanhando o sentido do deslocamento das meninas que se afastavam descendo a rua.

A tomada do plano-sequência Caminhada para a festa de rua, utilizada no filme, foi obtida por meio de uma refilmagem da cena. Problemas de continuidade percebidos durante a montagem, que ocorria paralelamente à filmagem, inviabilizaram a utilização das tomadas captadas originalmente. A cena foi refilmada no final de uma diária, em uma pequena brecha do cronograma de trabalho. Em função disso, o refazer da cena ocorreu em tempo extremamente reduzido.

Na primeira filmagem da sequência (ver Foto 19), foi usada a estratégia prevista para as cenas com caminhadas pelas ruas da Brasilândia: microfones de lapela em cada uma das personagens e o microfone aéreo operado pelo boom. A instalação dos microfones de lapela nas quatro personagens tomava de meia hora a quarenta minutos de trabalho. Na refilmagem, com a proximidade do final do dia, o tempo ficou escasso para a preparação, e a queda da luz do sol nos obrigou a desistir dos microfones de lapela e a utilizar exclusivamente o microfone direcional no boom. O microfone utilizado foi o Sennheiser MKH 416 com acessórios de proteção contra a incidência de vento. Na refilmagem da cena, parecíamos estar fadados ao fracasso pela impossibilidade de uso dos microfones de lapela. Porém, por uma feliz coincidência, a utilização exclusiva do direcional foi incrivelmente favorecida durante a tomada graças à presença de nuvens que nublaram o céu e permitiram a colocação do microfone na melhor posição para a captação das vozes, sem projetar sombra sobre as personagens. O plano sonoro obtido é coerente com a perspectiva da imagem, permite a intelecção das falas iniciais, mesmo ao longe, e preserva a espacialidade do ambiente, resultando numa composição sonora que reforça a naturalidade da cena. Captar apenas com o direcional tornou o processo de realização da tomada muito mais confortável. Pude me concentrar na monitoração da única fonte captada e avaliar com precisão a qualidade do sinal registrado. A operação do microfone foi extremamente complexa em função do longo e acelerado deslocamento realizado pelas personagens. 


\subsubsection{Sequência 15 - Festa de rua}

A longa sequência Festa de rua reúne a maioria dos personagens que participam da trama de Antônia; também apresenta os principais eventos dramáticos que impulsionarão o desenvolvimento da narrativa. Acompanhamos a chegada das meninas na embalada festa, Lena encontra o JP e Barbarah encontra o irmão Duda. Na lateral do palco, o quarteto aguarda o grande momento da estreia, a alegria é momentaneamente interrompida com a chegada do furioso Ermano, que vem tomar satisfações com Preta. O bafafá é controlado e as meninas são chamadas para o palco. A apresentação é um sucesso, apesar da manifestação de machismo na plateia. Após a apresentação, a comemoração é intensa - com direito a um candidato a empresário (Marcelo Diamante) -, porém curta, em função do desentendimento entre Preta e Mayah causado pelo ataque de ciúmes de Preta.
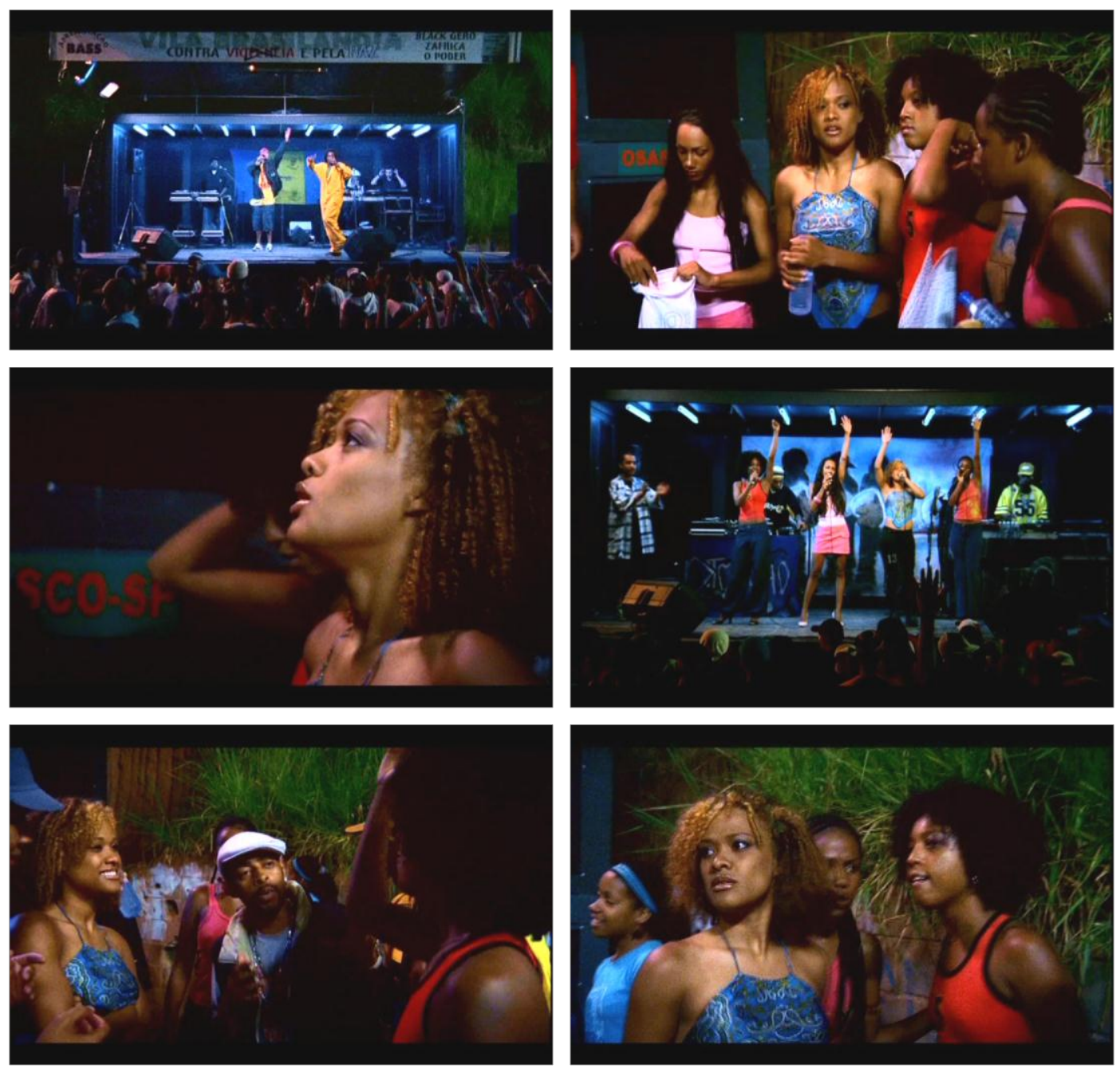

Fotogramas 11 - Sequência 15, Festa de rua (ANTÔNIA, 2007). 
Festa de rua foi a sequência com a realização mais complexa em todo o filme. Além das óbvias complicações de produção, envolvidas em uma filmagem noturna exterior com mais de trezentos figurantes, a proposta da direção de filmar "ao vivo" amplificava as dificuldades e tornava o trabalho de captação do som direto um desafio. A direção apostava que a captação em tempo real das apresentações musicais no palco e das ações que aconteceriam fora dele traria maior intensidade expressiva à cena. Assim, as ações com diálogos seriam realizadas simultaneamente ao show, que estaria sendo captado ao vivo e amplificado para a plateia. A questão aparentemente insolúvel era garantir o registro inteligível dos diálogos que ocorreriam ao lado do palco com a proximidade das caixas acústicas que forneceriam intensa pressão sonora para estimular a figuração e propiciar o retorno de som aos músicos durante a apresentação. Para a captação em tempo real seriam utilizadas duas câmeras, uma delas registraria prioritariamente as performances musicais, a partir de uma posição fixa frontal ao palco, e a outra acompanharia o desenrolar das ações das personagens. Em função da complexidade da sequência, foi realizado no dia anterior à filmagem um ensaio geral para a checagem e afinação das estratégias elaboradas para a sua realização. A partir do ensaio, ficou definido que a sequência seria captada por meio de quatro longos planos-sequências que cobririam a sucessão dos eventos que constituiriam a cena: da chegada das meninas até a briga entre Ermano e Preta; a subida ao palco e a apresentação do grupo Antônia; a comemoração após a estreia até a chegada de Marcelo Diamante; e a briga entre Preta e Mayah até o desabafo de Preta.

O registro sonoro das apresentações musicais ficou a cargo do estúdio móvel operado pelo técnico de som Roberto Marques, o Zorro, que utilizou em média dezoito pistas independentes para a gravação das músicas e da ambiência do show.

As condições eram totalmente desfavoráveis à captação do som direto. Foi explicitado para a direção que a possibilidade de edição dos planos sonoros captados nestas condições seria muito limitada. Para garantir, ao menos, a inteligibilidade dos diálogos, seria necessário uma relação satisfatória entre o nível de pressão sonora das vozes e o nível de pressão sonora da amplificação do palco. Assim, a estratégia para a captação do som direto da sequência envolveu primeiramente o controle do som amplificado do palco por meio dos seguintes procedimentos: o volume de saída do PA foi menor do que aquele encontrado em um show 
real; as caixas acústicas para a plateia ${ }^{111}$ foram posicionadas na linha do palco, porém distantes da área onde ocorriam os diálogos; as caixas acústicas de retorno do palco foram niveladas para atuar no limiar da audição dos músicos de modo a interferirem pouco na captação do som direto, gerando algumas queixas dos cantores; além disso, foi filtrada ${ }^{112}$ a saída do PA, amenizando a presença da música num intervalo de frequência fundamental para a compreensão da voz humana. Esses procedimentos não interferiram na qualidade do registro da música na medida em que eram realizados apenas na saída da amplificação do palco, após a captação pelo estúdio móvel.

A captação do som direto foi realizada por dois microfones supercardioides dinâmicos, modelo M69, fabricados pela Beyerdynamic, instalados em dois booms. O microfonista era responsável pela operação de um dos microfones, e o segundo boom era operado por mim. Esses microfones, originalmente desenvolvidos para serem usados no palco para a captação de vozes e instrumentos musicais de sopro, apresentam sonoridade cristalina, porém possuem baixa sensibilidade quando comparados aos direcionais condensadores normalmente empregados na captação com boom. Por isso, são normalmente chamados de microfones "duros", respondendo bem às altas pressões das fontes em primeiro plano e desprezando fontes com menor intensidade sonora.

A estratégia de captação apostava na baixa sensibilidade dos microfones e no controle da relação entre o nível sonoro das vozes e do nível da amplificação do palco. Assim, a eficiência dessa estratégia dependia também da intensidade das falas dos não-atores, que deveriam projetar as vozes como se estivessem realmente imersos em um ambiente extremamente ruidoso, numa atuação coerente com o que é vista na imagem e com o que seria ouvida posteriormente na trilha sonora mixada. Além disso, para extrair o melhor resultado da baixa sensibilidade (“dureza") do microfone escolhido, o enquadramento deveria favorecer o posicionamento do microfone o mais próximo possível ${ }^{113}$ da fonte sonora captada.

\footnotetext{
${ }^{111}$ As grandes caixas acústicas posicionadas nas laterais do palco, as quais podem ser vistas nos planos gerais do show cumpriam apenas função cenográfica. As caixas que geravam o som para plateia estavam posicionadas sobre tripés e eram dispostas conforme a necessidade de captação do som direto. ${ }^{112}$ Um equalizador gráfico com 31 bandas de frequência, instalado na saída da amplificação de som do palco, atenuava fortemente as frequências entre 300 e $5.000 \mathrm{~Hz}$, diminuindo a presença da música neste intervalo do espectro de frequências audíveis, "abrindo espaço" para a captação das falas pelo som direto.

${ }^{113}$ Nas condições acústicas da sequência, a distância ideal para a captação ficava entre 20 a 30 centímetros da fonte sonora.
} 
A Foto 21 permite visualizar o posicionamento do microfone durante a captação da cena da briga entre Ermano e Preta, ao lado do palco, antes da apresentação do grupo Antônia. A intensa projeção das vozes e a proximidade do microfone "duro" possibilitaram um registro com presença e inteligibilidade. Para garantir um "espaço sonoro livre" para a captação das vozes, a caixa acústica ao lado do palco, vista atrás do grupo, estava desligada durante a cena da briga, cumprindo apenas função cenográfica.

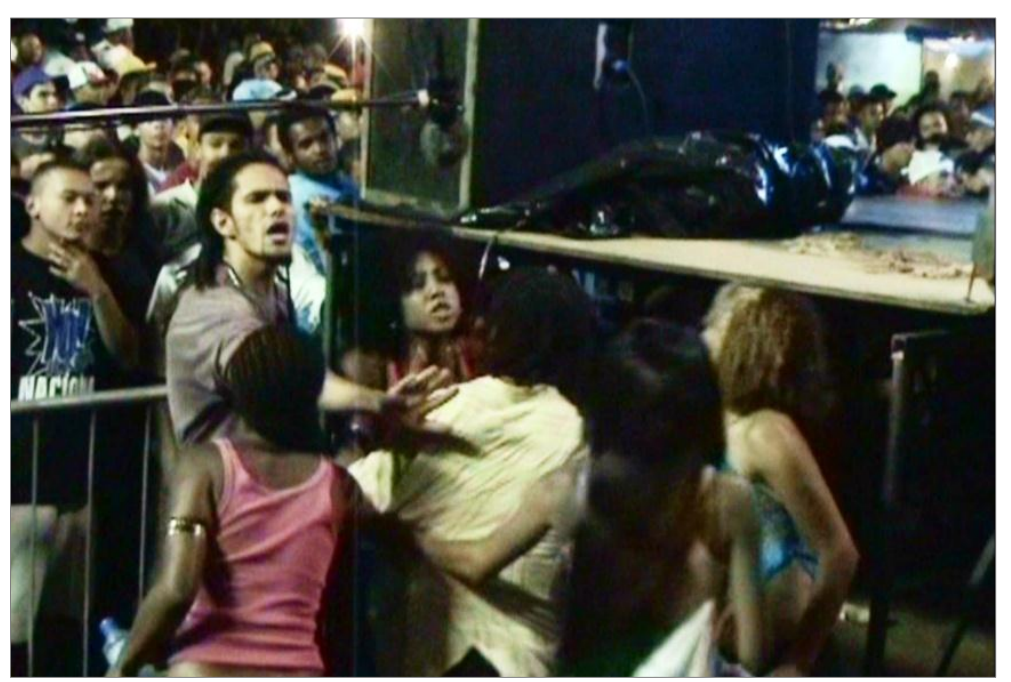

Foto 21 - Microfone sustentado pelo boom. Captação da sequência 15 - Festa de rua. Extraído do making of do filme Antônia (2007).

Os microfones operados pelos booms acompanhavam o deslocamento da câmera e captavam o som dos eventos enquadrados. Cada boom cobria uma área pré-determinada. $\mathrm{O}$ boom operado pelo microfonista era responsável por cobrir a região à esquerda de câmera, enviando o sinal para o gravador através de um sistema de radiotransmissão, enquanto o microfone operado por mim cobria as ações que ocorriam ao lado direito de câmera e estava conectado ao gravador via cabo. A Foto 22 permite visualizar a minha posição e a do microfonista em relação à câmera. No momento da foto, enquanto a câmera enquadrava a saída de Duda com o namorado, o microfonista posicionado à esquerda de câmera captava a cena. Na continuidade da ação, com a chegada de Ermano e até o final da briga com Preta, a captação foi realizada pelo microfone operado por mim. 


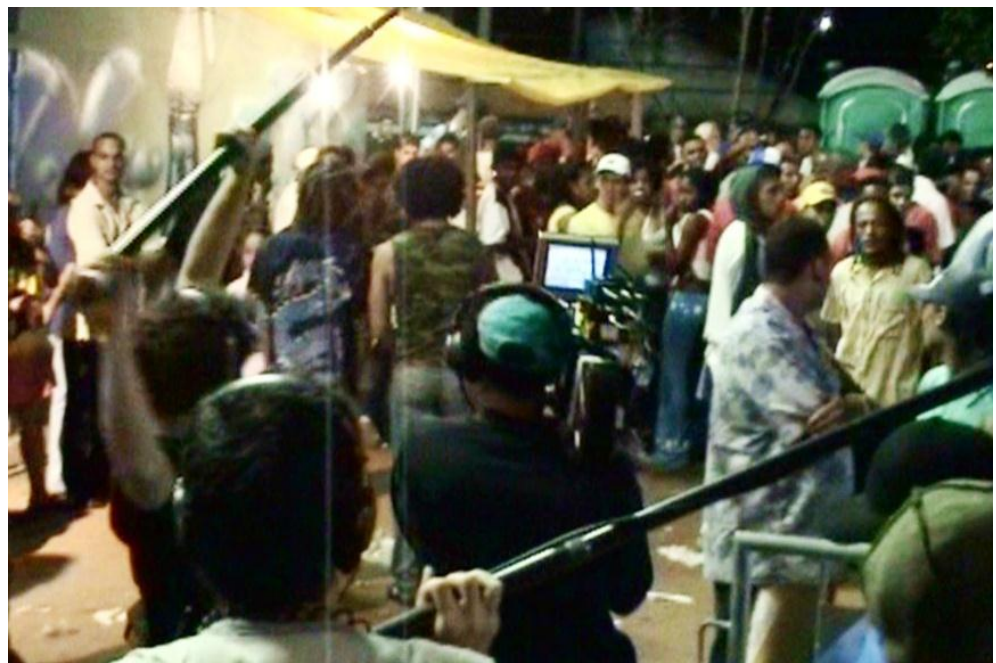

Foto 22 - Captação do som com dois booms cobrindo áreas diferentes. Captação da sequência 15 - Festa de rua. Extraído do making of do filme Antônia (2007).

A intensa movimentação da cena exigiu o emprego da configuração de alta portabilidade, com os equipamentos sustentados por mim, como pode ser visto na Foto 23.

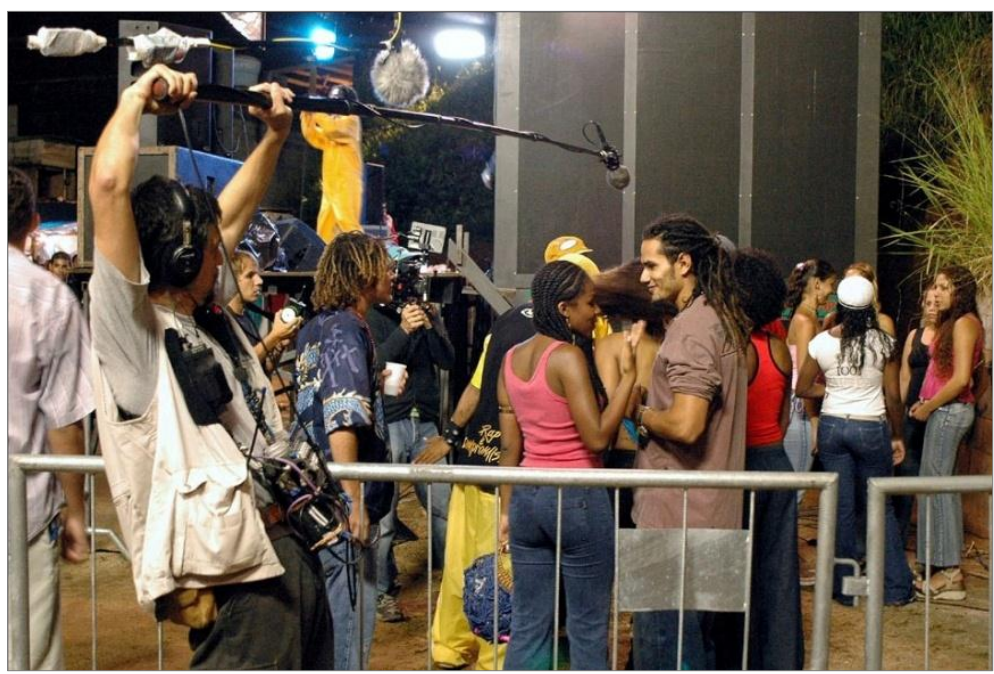

Foto 23 - Captação da sequência 15 - Festa de rua (ANTÔNIA, 2007). Arranjo de alta portabilidade, gravador e receptores dos sistemas de radiotransmissão presos ao corpo. 


\subsubsection{Sequência 19 - Preta chega à casa da mãe / Canto evangélico}

Na sequência 19, Preta chega à casa da mãe para pegar Emília. Acompanhamos a chegada de Preta abrindo a porta da sala e deparando-se com o coral evangélico, regido por sua mãe, ensaiando na sala. Contemplamos o coral por certo tempo até Preta fechar a porta e dirigir-se aos fundos, contornando a casa externamente. Preta encontra o pai sentado no quintal próximo à cozinha. Eles conversam brevemente, depois ela entra em casa e se deita com Emilia, que está dormindo na cama dos avós. O coral é ouvido durante toda a sequência.
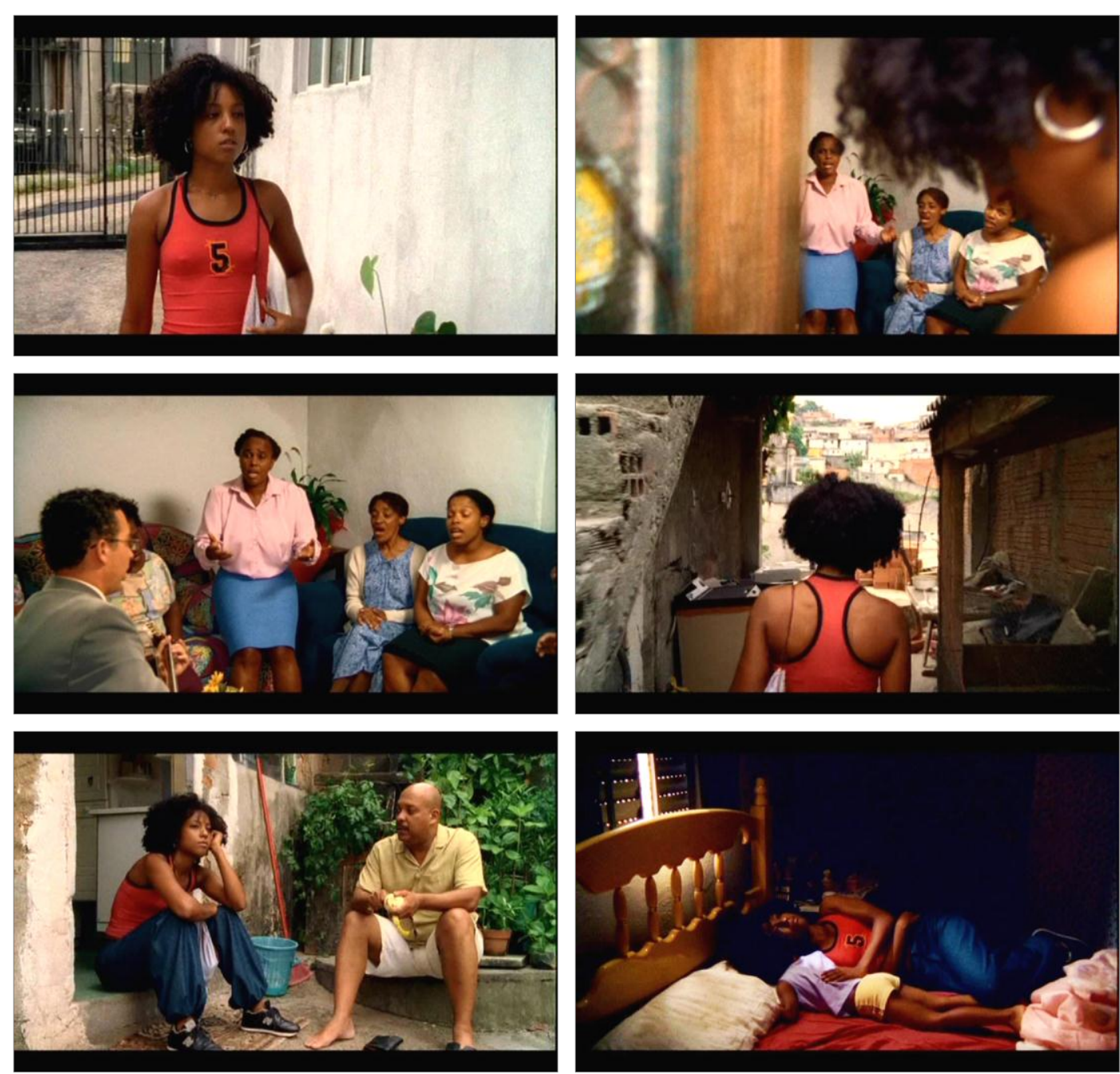

Fotogramas 12 - Sequência 19, Preta chega à casa da mãe / Canto evangélico (ANTÔNIA, 2007).

A cena foi rodada em plano-sequência utilizado integralmente no filme montado. $\mathrm{O}$ coro evangélico foi captado ao vivo. A estratégia de trabalho do som direto precisava equacionar a questão da captação do diálogo na porta da cozinha simultaneamente ao coro 
evangélico, garantindo a inteligibilidade das vozes de Preta e do pai, os quais dividiam o "espaço sonoro" com cântico. Além disso, era necessário captar e registrar o coro independentemente e com presença homogênea para que durante a mixagem ele pudesse ser direcionado livremente às pistas do surround ou às pistas frontais, em função da movimentação e do posicionamento de Preta no espaço diegético ao longo do planosequência.

Como não havia controle sobre a intensidade do som do coro evangélico na cozinha, a forma de reforçar a presença das vozes de Preta e do pai durante o diálogo foi por meio da utilização de microfones de lapela. Cada um dos personagens foi captado por um microfone de lapela com transmissão via rádio. Para manter a espacialidade da cena e municiar a edição de som com os ruídos da ação desenvolvida por Preta, foi utilizado, simultaneamente, um microfone direcional no boom operado pelo microfonista que acompanhava todo o percurso realizado pela personagem, captando também o diálogo final. O microfone utilizado foi um Sennheiser MKH 416 com acessórios de proteção contra vento conectado ao gravador por meio de cabo. Carregando o Cantar X e os receptores dos sistemas de rádio acompanhei o microfonista durante todo o trajeto, garantindo excelente recepção do sinal dos microfones de lapela.

Como a plataforma de gravação estaria em movimento durante o plano, foi determinado que o registro do cântico fosse realizado por uma segunda unidade de gravação, operada pela estagiária Tatiana Custódio, que estaria sediada no interior da casa. Foi utilizado um gravador DAT com duas pistas de gravação, da marca inglesa HHB, modelo PORTADAT PDR1000TC. A captação das vozes foi realizada pelo microfone Sennheiser MKH 435, um microfone cardioide aberto com sonoridade brilhante e cristalina, afixado no teto, bem no centro da sala, apontado para baixo. A captação do som do violão foi realizada por um microfone de lapela, com fio afixado próximo da abertura da cavidade de ressonância do instrumento. As vozes do coro e o som do violão foram gravados independentemente nas pistas do DAT para serem dosadas e processadas durante a mixagem.

Como ao longo do plano-sequência, a sala seria visualizada em quase sua totalidade. A intervenção acústica foi realizada por meio da instalação da tenda árabe no teto, que nunca seria enquadrado, e pela utilização de objetos de cena com forte coeficiente de absorção sonora (cortina, tapetes e móveis estofados recobertos com tecido), os quais contribuíram significativamente para a redução da reverberação, propiciando condições acústicas adequadas para a captação do coro. 


\subsubsection{Sequência 21 - Festa de burguês / Killing me softly}

$\mathrm{Na}$ sequência 21, o grupo Antônia, agenciado por Marcelo Diamante, canta profissionalmente em uma festa de aniversário de classe média alta. Já desfalcado pela ausência de Mayah, as cantoras interpretam Nada pode me parar, hit do grupo, para uma audiência indiferente. $\mathrm{O}$ total desinteresse da plateia é desconfortante. $\mathrm{O}$ anfitrião sobe ao palco para dedicar desafinadamente uma canção à aniversariante e é salvo pelo generoso auxílio musical do grupo Antônia, que canta harmoniosamente a música Killing me softly. A interpretação da canção inesperadamente reverte o estado de animo, arrancando entusiasmados aplausos da plateia.

A cena foi realizada com duas câmeras simultaneamente e captada como planosequência desde a apresentação da canção das meninas até o final de Killing me softly. Os planos de cobertura da festa, do tecladista e de Marcelo Diamante, foram rodados posteriormente para serem usados como inserts na montagem. 

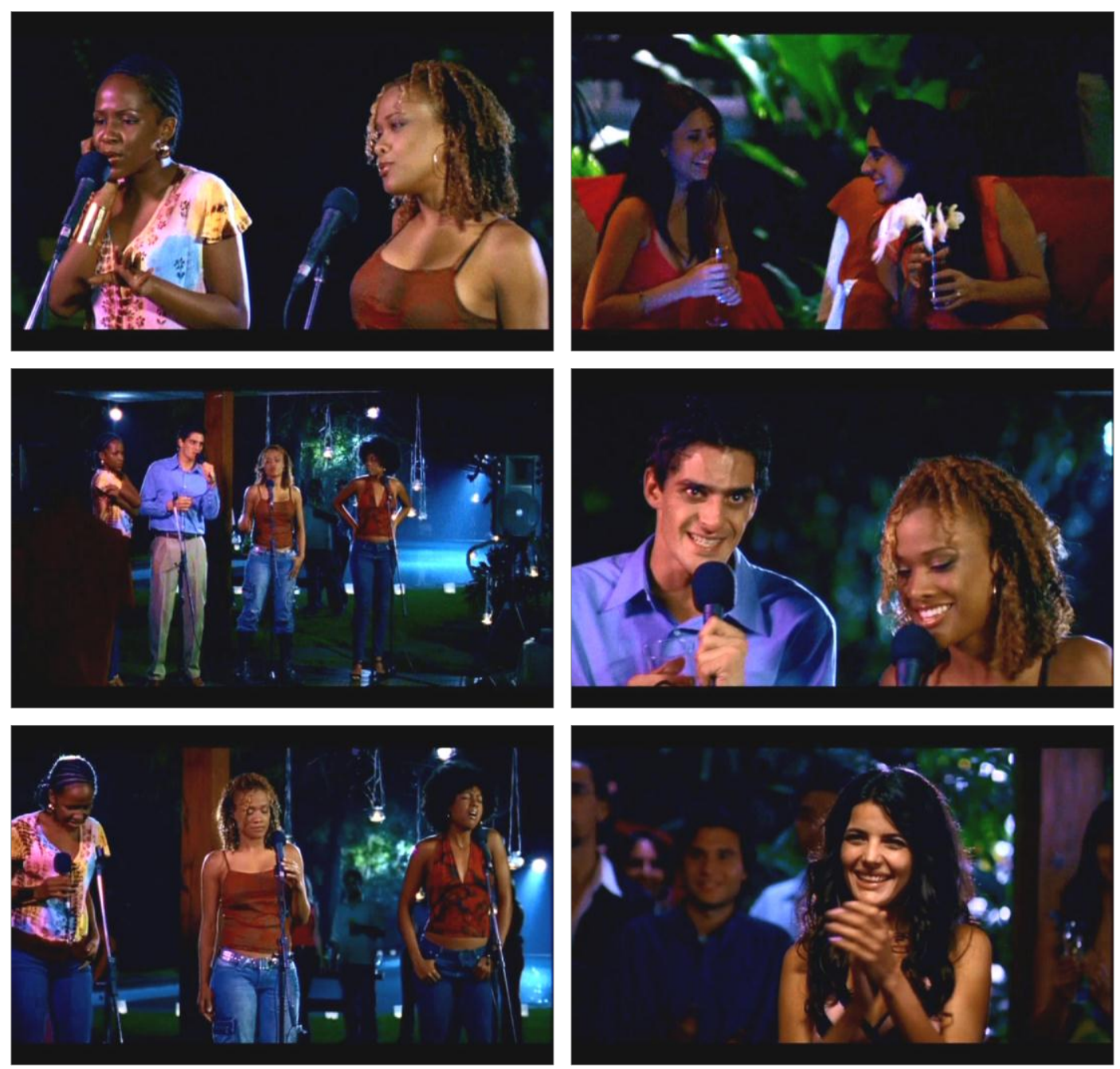

Fotogramas 13 - Sequência 21, Festa de burguês / Killing me softly (ANTÔNIA, 2007).

A estratégia para a captação de som seguiu o protocolo definido para os shows pequenos, com a equipe de som direto responsável pelo registro da apresentação musical. A captação das vozes foi realizada pelos três microfones que são vistos em cena nos pedestais sobre o palco. Foram empregados microfones dinâmicos, originalmente desenvolvidos para esta finalidade: dois modelos M69 da Beyerdynamic e um modelo SM58 da Shure, com características sonoras semelhantes. Além destes microfones, foi utilizado um microfone direcional de alta sensibilidade (Shoeps CMC6 com cápsula MK4) suspenso pelo boom, para captar a ambiência da apresentação, posicionado ao fundo da sala, apontando para as caixas acústicas dispostas ao lado do palco. Os microfones foram registrados independentemente, utilizando quatro pistas do gravador Cantar-X.

Além dos sinais dos quatro microfones, foram usadas duas pistas para gravar estereofonicamente a base rítmica da canção Nada pode me parar e duas pistas para gravar o 
acompanhamento musical de Killing me softly, executado ao vivo pelo teclado. O som da cena foi registrado utilizando as oito pistas do Cantar-X com as fontes sonoras conectadas diretamente ao gravador que liberava um retorno das pistas pré-mixadas para o sistema de PA, que amplificava o som para a audiência e para o palco.

\subsubsection{Sequência 33 - Caminhada Brasilândia - Provocação Robinho / Sequência 35 -}

\section{Caminhada Brasilândia - Espancamento Robinho}

Retornando para casa após uma apresentação musical, Barbarah e Preta encontram Robinho, que começa a provocá-las insistentemente. Ao descobrir que o rapaz foi o responsável pelo espancamento de seu irmão, Barbarah, passa a agredi-lo com violência.
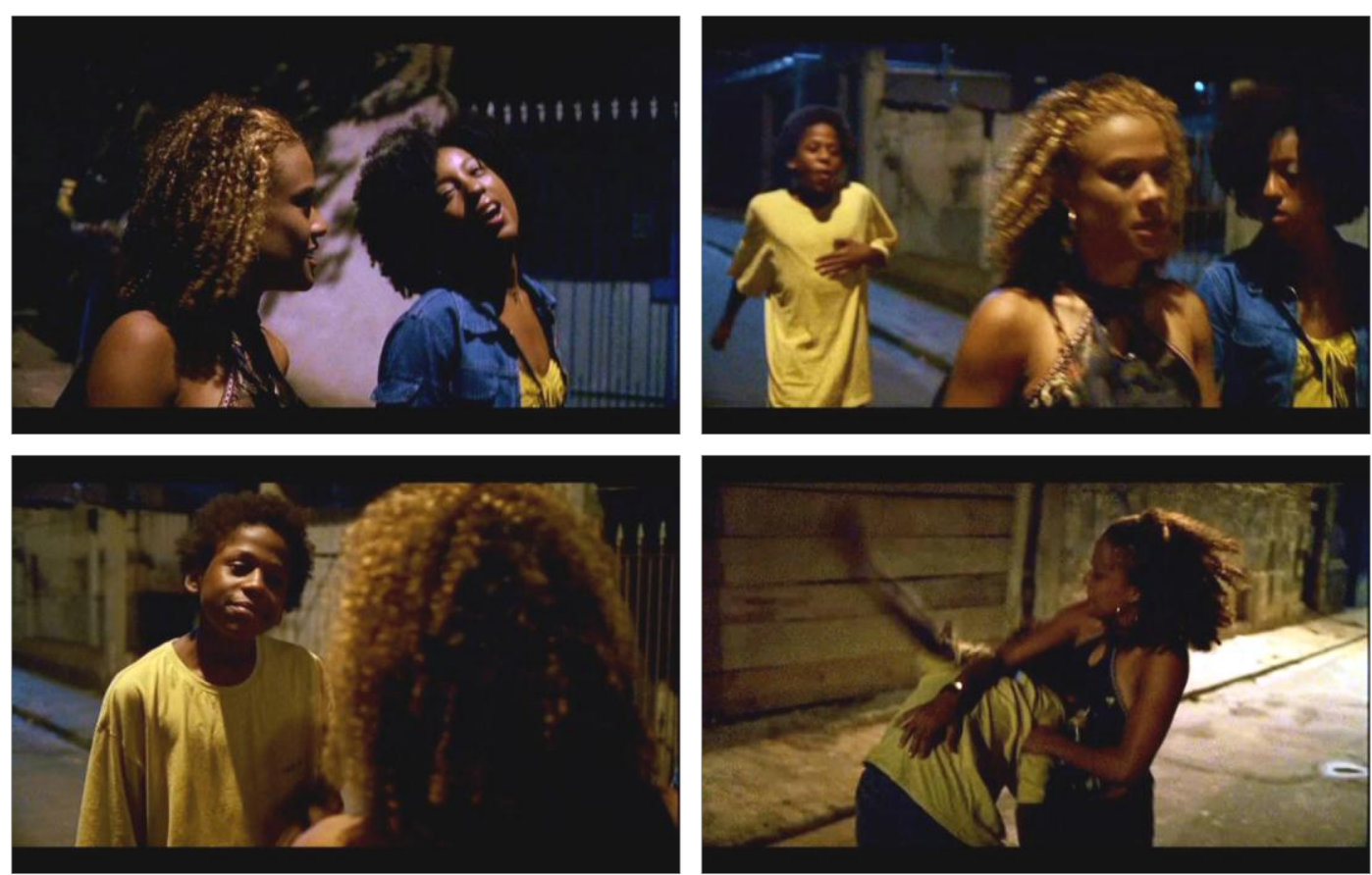

Fotogramas 14 - Sequências 33 e 35, Caminhada Brasilândia - Provocação Robinho e Espancamento Robinho (ANTÔNIA, 2007).

A sequência se inicia com a chegada do carro de Marcelo Diamante trazendo as meninas de carona à Brasilândia. Depois da troca de sapatos, Preta e Barbarah caminham para casa. Após o primeiro corte de imagem, acompanhamos a caminhada por meio de um longo plano-sequência, que é interrompido, temporariamente, pelo flashback de Robinho relembrando o confronto com Duda e retorna ao presente da ação diegética com a explosão de 
raiva de Barbarah, que avança sobre o rapaz. A seguir, será descrita a estratégia de captação do plano-sequência desde a caminhada até a briga com Robinho.

O plano-sequência foi realizado ao longo de um percurso de aproximadamente 300 metros de distância. Iniciava-se com o diálogo de Preta e Barbarah e prosseguia com a incorporação de Robinho à ação. A mise-en-scène estabelecida pelos três tornava a captação das vozes com o microfone direcional operado pelo boom muito difícil, pois as personagens femininas, que caminhavam à frente, algumas vezes "davam suas falas" mantendo a posição do rosto no sentido do deslocamento. Porém, em outros momentos, giravam o corpo em direção a Robinho para responder às suas provocações. Essas ações improvisadas, obrigavam a realização de bruscas correções do boom para a manutenção do eixo do microfone corretamente posicionado para a captação homogênea das vozes. Porém, a operação do boom era restringida em função da presença dos refletores de luz instalados nos postes da rua, que simulavam a própria iluminação pública, criando ao longo do percurso zonas intensamente iluminadas que projetavam a sombra do zeppelin ${ }^{114}$ sobre o corpo dos personagens, impedindo, assim, o correto posicionamento do boom. Essa limitação ao movimento do boom comprometia a qualidade da captação realizada pelo direcional, obrigando-nos a lançar mão da captação mista com o uso simultâneo dos microfones de lapela sem fio. No entanto, a utilização dos microfones de lapela também apresentava limitações. Como a ação era muito movimentada, o atrito das roupas sobre as cápsulas dos microfones gerava os incontroláveis ruídos que comprometiam o registro de algumas falas. Além disso, a opção pelos microfones de lapela determinava a interrupção do plano-sequência, antes do inicio da briga entre Robinho e Barbarah, para a retirada dos transmissores e das cápsulas para proteger os atores e evitar danos ao equipamento.

Assim, até o início cena da briga, a captação de som do plano-sequência foi realizada com a utilização de três microfones de lapelas sem fio e o microfone direcional (Sennheiser MKH 416), registrados em quatro pistas independentes no gravador. Durante a briga, a captação de som foi realizada exclusivamente pelo microfone direcional no boom.

O emprego da técnica mista apostava na complementação das qualidades de cada uma das captações e na supressão das suas imperfeições durante a edição de diálogos na pósprodução, ou seja, acreditava-se que o som dos microfones de lapela, devidamente editado para a eliminação dos ruídos de roupa, trouxesse a presença homogênea para todas as falas,

${ }^{114}$ Zeppelin é o no me dado ao acessório de proteção contra o vento, com formato fusiforme, usado para abrigar o microfone shotgun em cenas externas. 
cobrindo a deficiência do microfone direcional, e que o som do microfone direcional restituísse a desejada espacialidade natural para a sonoridade das vozes captadas com os microfones de lapela, auxiliando, também, na edição dos indesejáveis ruídos de roupa. Durante as tomadas, monitorei os microfones de lapela enquanto o microfonista monitorou o direcional.

A realização da cena envolveu a cooperação silenciosa da equipe de câmera e maquinária, que reduziu o número de participantes aos elementos essenciais para execução das tomadas e caminharam em silêncio, atendendo aos meus pedidos. . 


\section{CONSIDERAÇÕES FINAIS}

No percurso desenvolvido por este estudo pudemos perceber a influência dos aspectos financeiros e a preponderância da lógica empresarial como elementos determinantes para as notáveis mudanças, de ordem operacional e tecnológica, ocorridas na prática da produção cinematográfica norte-americana na transição do cinema silencioso para o cinema sonoro.

A mesma determinação empresarial que impulsionou o advento do cinema sonoro definiu os parâmetros de qualidade do som captado em sincronia com a imagem, que nos primeiros tempos do filme "falado" constituía a totalidade da trilha sonora cinematográfica. A inserção do som como um novo elemento narrativo no consolidado sistema de representação do cinema clássico norte-americano determinou as características técnicas do som direto, atendendo às necessidades estéticas de um código de representação já estruturado que demandava: fidelidade sonora em relação ao evento acústico representado; a presença contínua da voz como garantia da inteligibilidade da palavra falada; e um registro sonoro homogêneo nos planos constituintes de uma sequência.

As demandas sonoras do código de representação do cinema clássico forjaram a "naturalização" do padrão técnico do som direto que se perpetuou ao longo do tempo e pode ser percebido na prática profissional contemporânea. A busca pela captação e o registro de "um bom som direto" se materializa por meio de uma prática comum, partilhada por uma comunidade profissional de técnicos que empregam, em diferentes cinematografias, os mesmos procedimentos de trabalho que, em seu conjunto, constituem o método de trabalho de captação de som direto.

O "natural" padrão de qualidade do som direto orienta a rotina de trabalho do técnico de som que, partindo de uma base comum, desenvolve procedimentos específicos para adequar-se às demandas e as realidades orçamentárias de cada projeto. Assim, o conceito de método que sustenta nossa compreensão sobre o trabalho de captação de som é mais complexo do que aquele que estabelece que a simples repetição de normas pré-estabelecidas é suficiente para alcançar resultados previsíveis. Esse sentido limitante dado ao conceito de método, que excluí a atividade pensante e criativa do sujeito que o executa, é insuficiente para as demandas da realização audiovisual. $O$ conceito de método que pressupõe a constante renovação dos procedimentos e a adequação às demandas particulares, considera a inserção consciente do sujeito que o realiza num processo de atividade participativa e criadora. 
A rotina do método de trabalho do som direto se caracteriza pela aplicação sistemática de procedimentos que visam criar as condições necessárias para a captação do som sincrônico. Integrando a equipe de realização, o técnico de som direto define, junto às demais áreas técnicas, as demandas operacionais e infraestruturais para a obtenção das condições que viabilizem o trabalho. A conquista da atenção e o cuidado da equipe de realização para as especificidades do som no processo de realização cinematográfica são condições necessárias para a obtenção de "um bom som direto".

A singular circunstância da captação do som em sincronia com a imagem, subordinado às necessidades da composição visual e do enquadramento da cena, cria um vínculo de dependência entre o som direto e as demais áreas técnicas da realização. Somente o trabalho conjunto da equipe, assumindo o som direto como parte integrante do processo de realização e respeitando as particularidades físicas da matéria sonora, possibilita a superação dos inerentes obstáculos ao processo de captação e registro do som direto. A opção por filmar com som direto implica em procedimentos específicos que harmonizem as áreas técnicas envolvidas no processo de realização, esculpindo as condições necessárias para a captação sincrônica do som. Como o conflito original da captação de som direto é insuperável, com o posicionamento do microfone tradicionalmente definido pela imagem, as opções de direção e produção determinam o espaço de atuação do técnico de som, influenciando profundamente a qualidade do som direto. Esta compreensão do processo deveria orientar o trabalho de direção na escolha de locações silenciosas e decupagens adequadas para que cenas, com diálogos essenciais para a condução da narrativa, possam ser captadas garantindo a essência do trabalho do som direto: a inteligibilidade da palavra falada.

No método de trabalho do som direto, a captação e o registro da voz ocupam posição de destaque, tornando-se, no set, o principal foco de atenção do técnico de som. A tendência natural da voz em destacar-se de qualquer massa sonora e organizar a percepção auditiva ao seu redor é a justificativa sensorial dada por Michel Chion para o vococentrismo da trilha sonora cinematográfica. A presença da voz atrai a atenção do ouvinte que busca extrair seu significado. A importância da voz no som cinematográfico está principalmente associada ao conteúdo semântico que veicula. Por sustentar a expressão verbal e se constituir como o principal veículo da ação narrativa, a inteligibilidade da fala se torna o aspecto central no método de trabalho do técnico de som direto. A importância ocupada pela voz se manifesta em cada etapa do processo de constituição da trilha sonora cinematográfica. Na captação do som direto a intensidade e a presença das falas são controladas artificialmente em relação às 
demais fontes sonoras, como forma de compensar a falta de referências que permitem ao espectador/ouvinte, numa escuta direta, isolar a voz do diálogo dos ruídos circundantes e extrair seu significado. O método de trabalho do som direto prioriza a busca pela inteligibilidade sem esforço da palavra falada, por meio de procedimentos sistemáticos de controle e supressão dos outros elementos sonoros.

A homogeneidade da trilha sonora cinematográfica, fundamentalmente da voz (nos primeiros tempos do sonoro) que, segundo Altman, reforçava a invisibilidade da montagem e potencializava o caráter ilusionista da representação cinematográfica clássica, consolidou o método de captação do som direto. Assim, os parâmetros que caracterizam a qualidade técnica do som direto na atualidade decorrem do código de representação estabelecidos pelo cinema clássico, o qual determina um registro sonoro limpo, claro e homogêneo, com a atenção voltada para a perfeita compreensão da palavra falada. Esses parâmetros orientaram o desenvolvimento das ferramentas técnicas que satisfizessem às demandas de trabalho e foram internalizados na prática profissional como características inerentes ao som captado sincronicamente.

Nos procedimentos empregados pelo técnico de som direto, é considerada a característica peculiar do som que, diferentemente da luz ao se propagar, contorna e envolve os objetos, determinando um comportamento "indisciplinado" da matéria sonora. Em comparação com a imagem, as fronteiras do "quadro sonoro", durante a captação, não são tão precisas quanto as do quadro da imagem delimitado pela câmera. Assim, ao contrário do que imagina o senso comum, o emprego dos microfones direcionais, mesmo os hipercardioides, apenas atenua os ruídos que se encontram fora do eixo de captação do microfone, porém não consegue suprimi-los completamente. Para o técnico de som direto, a única forma efetiva de "delimitar o quadro" sobre o som desejado (a voz) é aproximando o microfone da fonte (a boca do ator) para que as palavras sejam captadas com intensidade predominante e mascarem o ruído ambiente circundante. Os avanços tecnológicos, com a tendência geral à miniaturização dos dispositivos de captação, permitindo o desenvolvimento dos pequenos microfones de lapela (possíveis de serem escondidos sob a roupa dos atores) e o aprimoramento dos sistemas de radiotransmissão do sinal de áudio captado pelos microfones, disponibilizaram ao técnico de som ferramentas para a superação da tradicional limitação imposta pela imagem para a colocação do microfone na melhor posição de captação em relação à fonte sonora na realização cinematográfica ficcional. Estas ferramentas contemplam 
as especificidades físicas da matéria sonora e respondem à demanda técnica/estética do som sincrônico.

Os microfones de lapela sem fio, associados à recente aquisição tecnológica, disponibilizada pela indústria eletrônica (gravadores portáteis digitais multipista) criam sistemas de captação e registro sonoro que satisfazem a necessidade original do cinema clássico: a almejada sonoridade das falas em contínuo close up. Ao garantir uma captação com presença destacada e o registro independente das vozes, estas ferramentas respondem à demanda original do som direto de propiciar a perfeita inteligibilidade da fala, respeitando a convenção de manter o microfone fora do campo de visão da câmera. As mudanças no método de trabalho pela disseminação dos novos sistemas de captação/registro de som direto ainda estão em curso, o multipista portátil digital modificou o procedimento de monitoração e a precisão na avaliação da qualidade do material registrado, as consequências são percebidas nos estágios subsequentes da realização, montagem da imagem e edição de som, que recebem uma quantidade significativamente maior de material proveniente da captação do som direto num grau de acabamento menos definido, obrigando a renovação dos procedimentos de trabalho também nestas etapas.

O potencial trazido pela nova tecnologia tende a estimular as práticas de captação e de edição de som que adotam o emprego indiscriminado dos microfones de lapela sem fio na busca por uma sonoridade do registro direto mais limpo e ainda mais homogêneo. Se esta tendência for verificada, o espaço de atuação criativa do técnico de som direto que resulta na constituição de texturas sonoras particulares, fruto da sensibilidade e das escolhas (estratégias de captação, tipo de microfone empregado, intervenções acústicas nos espaços de filmagem) realizadas pelo profissional do som direto, se tornará mais restrito e muito mais normatizado.

No som direto captado nos longas-metragens Contra todos e Antônia prevaleceram as características técnicas/estéticas do hegemônico cinema narrativo. Nestas realizações, os procedimentos de trabalho empregados pelo som direto, pautados pelo padrão de qualidade herdado do cinema clássico, buscaram obter um registro sonoro limpo, claro e homogêneo, priorizando a presença destacada da voz e a consequente inteligibilidade sem esforço das falas. Rever os processos de realização de Contra todos e Antônia suscita uma indagação: por que em filmes com propostas de realização tão ousadas, que questionavam modelos convencionais de realização/representação, o método de trabalho do som direto foi pautado pelo padrão técnico tradicional? 
Durante a preparação de cada um dos filmes existiam dúvidas acerca do padrão estético do som direto. Seriam aceitas descontinuidades do ruído ambiente ou situações de pouca inteligibilidade das falas? Qual textura sonora se adequaria àquelas propostas de realização? As demandas de realização impregnariam o som direto com características particulares ou seria possível preservar o padrão tradicional na captação de som? A impossibilidade de conceber outra estética para o som direto, resultado da prevalência do padrão "natural", e a certeza de que o som direto com as características técnicas tradicionais garantiria matéria-prima sonora para qualquer opção estética da trilha sonora que fosse definida ao longo da pós-produção, determinaram a opção pelo padrão técnico tradicional, o qual balizou os procedimentos de trabalho na captação do som direto dos filmes realizados.

Os procedimentos de trabalho foram organizados de forma a responder às demandas trazidas pelas realizações, garantindo o cumprimento das premissas definidas pelos diretores (total liberdade de ação para os atores e atrizes; inexistência de amarras técnicas para a realização das cenas; impressão de flagrar a realidade). A portabilidade e a flexibilidade para a captação foram os atributos centrais na escolha do aparato técnico, na constituição das equipes e na definição das estratégias de captação.

A decisão pelo padrão técnico/estético tradicional na realização de Contra todos e Antônia se mostrou acertada, a evidente função narrativa desempenhada pelos diálogos no desenvolvimento das histórias destes filmes se realiza plenamente, por meio da fácil compreensão das falas dos personagens que, a despeito das ações desenvolvidas com movimentação e textos improvisados, foram captadas com presença viabilizando a chamada "audição semântica"115. Atuando num nível sensório mais sutil, a fidelidade das vozes associada à adequada representação sonora dos espaços dos quais emanam, graças à preservação das particulares reverberações impressas nas vozes, como "impressões digitais sonoras" dos espaços que as contêm, conformam um potente estímulo auditivo para a impressão de "verdade" alcançada por estas películas.

A homogeneidade sonora, típica característica do som direto tradicional, foi fundamental em algumas sequências de Contra todos para a suavização dos cortes bruscos entre os planos de imagem, decorrentes dos jump cuts empregados na montagem dos planossequências. O efeito de amenizar as passagens descontínuas da imagem, atenuando a desconfortável sensação de vertigem causada pela sucessão fragmentada da ação, foi

115 “Audição semântica" é definida por Chion (1994, p. 28) como a forma de escuta que interpreta uma mensagem textual, carregada pelo estímulo sonoro da voz, no contexto de uma língua. 
percebido durante o trabalho, por mim realizado, de edição de diálogos, na segunda sequência de Contra todos (Jantar - casa de Teodoro). A primeira tentativa da edição dos diálogos desta sequência seguiu literalmente os cortes de imagem que reiterava as transições abruptas entre os planos, causando desconforto e distanciamento da cena montada. Para atenuar esta sensação foi realizada a edição dos diálogos, objetivando suavizar as passagens bruscas realizadas pela imagem. A homogeneidade do som direto permitiu a utilização da técnica do cross fade sonoro nos cortes entre os planos de imagem, suavizando a fragmentação da montagem por meio de uma maior fluidez sonora.

O advento da tecnologia digital portátil multipista foi essencial na captação/registro sonoro direto em Antônia. A concretização da proposta de direção, de Tata Amaral, só se viabilizaria por meio das ferramentas disponibilizadas por estas plataformas de registro sonoro. A possibilidade de registrar vários canais (microfones direcionais aéreos sustentados por boom e lapelas sem fio) em pistas independentes (sem a necessidade de mixá-los durante a captação) criou as condições técnicas para implementação das estratégias de captação desenvolvidas para responder às complexas demandas de realização de Antônia. Dessa forma, buscar a relação entre o potencial técnico destes equipamentos e as mudanças, a longo prazo, no método de trabalho do som direto é um possível desdobramento desta pesquisa.

O espaço de atuação criativa do técnico de som direto na realização cinematográfica ficcional não é tão evidente quanto às outras áreas envolvidas na produção, tais como: a fotografia ou a direção de arte. A invisibilidade da matéria sonora não facilita a percepção da atuação criativa que o profissional do som sincrônico pode desempenhar na equipe de realização. Além disso, os procedimentos constituintes da rotina básica do som direto, por mais importantes que sejam para a qualidade do registro sonoro, são desprovidos de qualquer pretensão artística. A rotina de controle e supressão das fontes sonoras indesejadas (interrompendo as atividades periféricas no set; silenciando solas de sapato, xícaras e pratos; solicitando que os atores controlem os ruídos produzidos durante a cena) é fundamental para a obtenção de um "bom som direto" e está presente na prática de trabalho desde o início deste ofício. Estes procedimentos, ainda que necessários e importantes, implicam apenas na repetição de um protocolo que, no máximo, exige a atenção e o cuidado do técnico de som, mas nenhuma competência criativa.

No entanto, contrapondo-se a esta dimensão estritamente mecânica do trabalho do técnico de som, podemos afirmar que a aplicação do conjunto destes procedimentos, associados à escolha dos microfones; a distância do microfone em relação à fonte; ao controle 
da reverberação, entre outras possíveis decisões, conformam a textura sutil do som direto, que possibilita a este registro reforçar a impressão de pertencimento de uma fonte sonora ao espaço do qual emana. Mesmo assumindo a dependência do som direto em relação as demais instâncias da realização cinematográfica (demandas de roteiro, opções de direção), a sonoridade (qualidade impalpável) da gravação, resulta das escolhas do profissional do som direto.

Se a referência básica para os procedimentos de trabalho do técnico de som é explicitada como a procura por um som em contínuo close up, uma atuação sutil - invisível, inclusive, para a maioria dos componentes da equipe de realização cinematográfica -, que depende da sensibilidade, da experiência e do potencial criativo do profissional do som direto, busca a fidelidade da voz com a preservação da particular textura do espaço de onde esta voz emana para alcançar uma representação sonora adequada à imagem captada sincronicamente. 


\section{REFERÊNCIAS}

ALTMAN, Rick. Sound space. In: ALTMAN, Rick (Org.). Sound theory: sound practice. New York: Routledge, 1992. p. 46-64.

ANTÔNIA. Direção de Tata Amaral. Coração da Selva: Dist. Playarte Home Video, 2007. (90 min): son., color,; $35 \mathrm{~mm}$.

A TESTEMUNHA. Direção de Peter Wier. Edward S. Feldman: Dist. Paramount Pictures, 1985. (119 min), son., color,; $35 \mathrm{~mm}$.

BORDWELL, David. La introducción del sonido. In: BORDWELL, David, STAIGER, Janet, THOMPSON, Kristin. El cine clásico de Hollywood. Barcelona: Paidós, 1997a. p. 331356.

Las pruebas Mazda de 1928. In: BORDWELL, David, STAIGER, Janet, THOMPSON, Kristin. El cine clásico de Hollywood. Barcelona: Paidós, 1997b. p. 327-330.

CHION, Michel. Audio-vision: sound on screen. New York: Columbia University Press, 1994.

. El Cine y sus oficios. Madrid: Ediciones Cátreda, 1992.

La voz en el cine. Madrid: Ediciones Cátreda, 2004.

CONTRA todos. Direção de Roberto Moreira. Coração da Selva: Dist. Warner Bros., 2004. (95 min), son., color,; $35 \mathrm{~mm}$.

COSTA, Fernando Morais. O som no cinema brasileiro. Rio de Janeiro: 7 Letras, 2008.

CRAFTON, Donald. The Talkies: American cinema's transition to sound 1926 - 1931. Berkeley, University of California Press, 1997.

DA-RIN, Silvio. Espelho partido: tradição e transformação do documentário. Rio de Janeiro: 2004. 
GOMERY, Douglas. The coming of Sound: Technological Change in the American Film Industry. In: WEIS, Elisabeth; BELTON, John (Org.). Film sound: theory and practice. New York: Columbia University Press, 1985. p. 5-24.

GUIMARÃES, Clotilde Borges. A introdução do som direto no cinema documentário brasileiro na década de 1960. 2008. Dissertação (Mestrado em Cinema) - Escola de Comunicações e Artes, Universidade de São Paulo, São Paulo, 2008.

HANDZO, Stephen. Appendix: A narrative glossary of film sound technology. In: WEIS, Elisabeth; BELTON, John (Org.). Film sound: theory and practice. New York: Columbia University Press, 1985. p. 383-425.

HOLMAN, Tomlinson. Sound for film and television. Boston: Focal Press, 2002.

LOBRUTO, Vincent. Interviews with creators of film sound. Westport: Praeger Publishers, 1994.

MENDES, Eduardo Simões dos Santos. Walter Murch: a revolução no pensamento sonoro cinematográfico. 2000. Tese (Doutorado em Cinema) - Escola de Comunicações e Artes, Universidade de São Paulo. São Paulo, 2000.

MOMENTO de decisão. Direção de Herbert Ross. Hera Production: Dist. 20 th Century Fox, 1977. (119 min), son., color,; $35 \mathrm{~mm}$.

MORIN, Edgar. Ciência com consciência. Rio de Janeiro: Bertrand Brasil, 2000.

SCHATZ, Thomas. O gênio do sistema: a era dos estúdios em Hollywood. São Paulo: Companhia das Letras, 1988.

SEBA, Alejandro; LOREDO, Leandro. Sonido directo: algunas consideraciones. In: Kane 02 - ciudad universitaria. Buenos Aires: Imprenta Triñanes, 2005, p. 62-70.

STAN, Robert. O espetáculo interrompido: literatura e cinema da desmistificação. São Paulo: Paz e Terra, 1981.

XAVIER, Ismail. $O$ discurso cinematográfico: a opacidade e a transparência. São Paulo: Paz e Terra, 1984. 
YEWDALL, David Lewis. Practical art of motion picture sound. Boston: Focal Press, 2007. 


\section{BIBLIOGRAFIA COMPLEMENTAR}

ALTMAN, Rick. Introduction: sound's dark corners. In: ALTMAN, Rick (Org.). Sound theory: sound practice. New York: Routledge, 1992. p. 171-177.

Introduction: sound/history. In: ALTMAN, Rick (Org.). Sound theory: sound practice. New York: Routledge, 1992. p. 113-125.

The evolution of sound technology. In: WEIS, Elisabeth; BELTON, John (Org.). Film sound: theory and practice. New York: Columbia University Press, 1985. p. 44-53.

(Org.). Yale french studies: cinema/sound. New Haven: Yale University, n. 60, 1980.

AUMONT, Jacques et al. A estética do filme. Campinas: Papirus, 1995.

BELTON, John. Technology and aesthetics of film sound. In: WEIS, Elisabeth; BELTON, John (Org.). Film Sound: theory and practice. New York: Columbia University Press, 1985. p. 63-72.

1950s Magnetic sound: the frozen revolution. In: ALTMAN, Rick (Org.). Sound Theory - Sound Practice. New York: Routledge, 1992. p. 154-170.

BERNARDET, Jean-Claude. Cineastas e imagens do povo. São Paulo: Companhia das Letras, 2003.

BERNARDET, Jean-Claude. O som no cinema brasileiro. Filme e cultura, Rio de Janeiro, n. 37, p. 2-34, jan./mar. 1981.

BORDWELL, David; STAIGER, Janet; THOMPSON, Kristin. El cine clásico de Hollywood. Barcelona: Paidós, 1997.

BORDWELL, David. O cinema clássico hollywoodiano: normas e princípios narrativos. In RAMOS, Fernão (Org.). Teoria contemporânea do cinema: documentário e narratividade ficcional. São Paulo: Editora SENAC São Paulo, 2005.v. 2. 
BORDWELL, David; THOMPSON, Kristin. Fundamental Aesthetics of Sound in the Cinema. In: WEIS, Elisabeth; BELTON, John (Orgs.). Film sound: theory and practice. New York: Columbia University Press, 1985. p. 180-199.

BURCH, Noel. Práxis do cinema. São Paulo: Perspectiva, 1992.

CAVALCANTI, Alberto. Filme e realidade. São Paulo: Livraria Martins Editora, 1953.

CHION, Michel. El sonido. Barcelona: Ediciones Paidós Ibérica, 1999.

COFFEY, John. An open letter from your sound department. Disponível em: <www.filmsound.org/production-sound/openletter.htm>. Acesso em: 20 nov. 2008.

COSTA, Flavia Cesarino. O primeiro cinema: espetáculo, narração e domesticação. São Paulo: Scritta, 1995.

DOANE, Mary Ann. A voz no cinema: a articulação de corpo e espaço. In: XAVIER, Ismail (Org.). A experiência do cinema. Rio de Janeiro: Edições Graal - Embrafilmes, 1983. p. 457475.

EISENSTEIN, Sergei, PUDOVKIN Vsevolod, ALEXANDROV Grigori. A Statement. In: WEIS, Elisabeth, BELTON, John (Orgs.). Film Sound: theory and practice. New York: Columbia University Press, 1985. p. 83-85.

HOLMAN, Tomlinson. 5.1 Surround Sound: up and running. Boston: Focal Press, 2000.

LABRADA, Jeronimo. Registro sonoro: técnica básica. San Antonio de Los Baños: Escola Internacional de cine y TV, 1989.

LASTRA, James. Reading, writing and representing sound. In: ALTMAN, Rick (Org.). Sound theory : sound practice. New York: Routledge, 1992. p. 65-86.

LITLE, Michael. The sound track of the rules of the game. In: WEIS, Elisabeth, BELTON, John (Orgs.). Film sound: theory and practice. New York: Columbia University Press, 1985. p. $312-322$.

PASQUARIELO, Nicholas. Sound of movies: interviews with the creators of Feature Sound Tracks. San Francisco: Port Bridge Books, 1997. 
PRODUCTION sound essential (or how eggs should be sucked). Disponível em: <www.amps.net/technical/Essentials.htm>. Acesso em: fev. 2009.

RATCLIFF, John. Time code: a user's guide. Boston: Focal Press, 1999.

SHEPHERD, Ashley. Pro Tools for video, film, and multimedia. Boston: Musk \& Lipman, 2003.

THOM, Randy. ADR Discussion. Disponível em: <www.filmsound.org/QA/ADRDiscussion.htm>. Acesso em: 10 jan. 2009.

WEIS, Elisabeth; BELTON, John (Orgs.). Film sound: theory and practice. New York: Columbia University Press, 1985.

WURTZLER, Steve. She sang live, but the microphone was turned off - The live, the recorded, and the subject of representation. In: ALTMAN, Rick (Org.). Sound theory: sound practice. New York: Routledge, 1992. p. 87-103. 


\section{APENDICE A - LISTA DAS SEQUÊNCIAS DE CONTRA TODOS}

A divisão em sequências utilizada nesta pesquisa foi realizada a partir do filme montado, lançado em DVD, em 2005, e tem como parâmetro as mudanças espaciais de cada uma das unidades dramáticas e seus particulares procedimentos de captação. É uma divisão funcional que atende às necessidades de organização deste trabalho.

Lista de sequências de Contra Todos:

1. Assistindo vídeo na casa de Teodoro.

2. Jantar - casa de Teodoro.

3. Créditos de abertura.

4. Soninha passeia na Galeria do Rock.

5. Cláudia arruma-se para sair.

6. Cláudia caminha pela rua.

7. Claudia no açougue.

8. Teresinha e Teodoro chegam com a mudança - casa de Terezinha.

9. Soninha caminha nas ruas do centro de São Paulo.

10. Cláudia canta Bwana - casa de Teodoro.

11. Soninha no ônibus.

12. Cláudia e Júlio transam - casa de Teodoro.

13. Terezinha e Teodoro relembram primeiro encontro - casa de Terezinha.

14. Soninha no ônibus.

15. Soninha caminhando para casa.

16. Soninha chega em casa e encontra com Júlio - casa de Teodoro.

17. Teodoro implica com Soninha - casa de Teodoro.

18. Teodoro espanca Soninha - casa de Teodoro.

19. Teodoro no quarto - casa de Teodoro.

20. Cláudia na cozinha - casa de Teodoro.

21. Soninha no quarto - casa de Teodoro.

22. Oração na casa do enfermo

23. Despedida em frente à casa do enfermo.

24. Teodoro lê a Bíblia com Soninha - casa de Teodoro.

25. Teodoro e Cláudia transam - casa de Teodoro. 
26. Soninha vai ao banheiro - casa de Teodoro.

27. Soninha caminha com a amiga e encontra Marcão.

28. Teodoro e Cláudia conversam na cozinha - casa de Teodoro.

29. Soninha no campinho.

30. Claudia estende roupas avista movimento de policiais.

31. Soninha relata a morte de Júlio - casa de Teodoro.

32. Cláudia passando roupa chega Waldomiro - casa de Teodoro.

33. Claudia sofre pela morte do Júlio - casa de Teodoro.

34. Teodoro e Waldomiro são contratados.

35. Teodoro e Waldomiro no carro.

36. Teodoro e Waldomiro executam Tião.

37. Teodoro e Waldomiro tomando cerveja.

38. Teodoro encontra a casa destruída - casa de Teodoro.

39. Soninha vasculha a casa - casa de Teodoro.

40. Soninha toma banho e assume o lugar de Cláudia - casa de Teodoro

41. Waldomiro encontra Cláudia na rua.

42. Teodoro no bar procurando Cláudia.

43. Waldomiro e Cláudia no quarto do hotel.

44. Teodoro briga no bar.

45. Teodoro dorme no carro.

46. Cláudia caminha nas ruas do centro de São Paulo.

47. Cláudia conhece Lindoval - recepção do hotel.

48. Cláudia e Lindoval transam no chuveiro.

49. Soninha e Waldomiro conversam na sala - casa de Teodoro.

50. Soninha e Waldomiro almoçam na cozinha - casa de Teodoro.

51. Açougueiro contrata os serviços de Teodoro.

52. Teodoro assassina Marcão.

53. Teodoro avisa que vai se casar - casa de Teodoro.

54. Teodoro e Waldomiro conversam no quarto - casa de Teodoro.

55. Cláudia e Lindoval no quarto do hotel.

56. Lindoval espancado por carecas.

57. Soninha pinta o quarto. Diálogo com Regininha - casa de Teodoro.

58. Cláudia procura por Lindoval - recepção do hotel.

59. Terezinha conta à amiga que vai se casar. 
60. Cláudia no hospital à procura de Lindoval.

61. Terezinha recebe fita de vídeo.

62. Cláudia visita Lindoval no hospital.

63. Teodoro estupra Terezinha - casa de Terezinha.

64. Waldomiro experimenta novo carro.

65. Waldomiro e Soninha comemoram - casa de Teodoro.

66. Waldomiro e Soninha transam - casa de Teodoro.

67. Morte de Teodoro - casa de Teodoro.

68. Teodoro chega a casa e encontra Cláudia (flashback).

69. Waldomiro encontra Teodoro e Cláudia mortos (flashback).

70. Waldomiro flagra Cláudia e Júlio transando (flashback).

71. Soninha mostra vídeo com Teodoro e Cláudia transando (flashback).

72. Waldomiro foge com dinheiro de Teodoro (flashback).

73. Festa de casamento de Waldomiro e Terezinha

74. Créditos finais 


\section{APENDICE B - LISTA DAS SEQUÊNCIAS DE ANTÔNIA}

A divisão em sequências utilizada nesta pesquisa foi realizada a partir do filme montado, lançado em DVD, em 2007, e tem como parâmetro as mudanças espaciais de cada uma das unidades dramáticas e seus particulares procedimentos de captação. É uma divisão funcional que atende às necessidades de organização deste trabalho.

Lista de sequências de Antônia:

1 Meninas caminham na Brasilândia final de tarde.

2 Show de abertura. Camarim / palco / saída.

3 Na van pedido para abrir o show do grupo O Poder (na van).

4 Chegada à estação de trem - estação fechada.

5 Preta e Ermano brigam (flashback).

6 Barbarah e Duda treinam Kung Fu (flashback).

7 Entram na plataforma da estação.

8 Espera do trem na plataforma / cantam Olhos Coloridos.

9 Trem chegando / título.

10 Lena e Maionezi no chuveiro.

11 Duda expulsa Robinho - futebol na quadra.

12 Ensaio do Antônia no ginásio.

13 Mudança de Preta.

14 Caminhada para a festa de rua.

15 Festa de rua. (show grande).

16 Caminhada de volta para casa Preta e Barbarah.

17 Duda e Namorado feridos / Levados ao hospital.

18 Chegada ao hospital / Relato médico.

19 Preta chega à casa da mãe / Canto evangélico.

20 Marcelo Diamante contrato de trabalho.

21 Festa de burguês / Killing me softly (show pequeno).

22 Retorno à Brasilândia de carro - conversam no carro.

23 Caminhada para casa. Preta, Barbarah e Lena - na Brasilândia.

24 Preta e Hermano discutem - no portão da casa de Barbarah.

25 Preta chora / Amanhece - na laje.

26 Duda volta para casa / Lena chama Barão - casa de Barbarah. 
27 Chegada de Duda / Festa com bolo - casa de Barbarah.

28 Meninas conversam na laje. Lena deixa o grupo.

29 Lena e Maionezi discutem a gravidez (flashback).

30 Meninas conversam na laje. Lena deixa o grupo.

31 Preta e Barbarah cantam Ela é demais - no Coppola Music (show pequeno).

32 Chegada de carro à Brasilândia - Preta e Barbarah descem do carro.

33 Caminhada Brasilândia / Provocação Robinho.

34 Briga Robinho e Duda (flashback).

35 Caminhada Brasilândia / Espancamento Robinho.

36 Prisão de Barbarah - na delegacia.

37 Preta canta Como uma onda no mar - no Coppola Music (show pequeno)..

38 Preta conversa com a mãe - na casa da mãe.

39 Preta e Emilia caminham para a casa - ruas da Brasilândia.

40 Preta e Diamante conversam - na barraca do cachorro quente.

41 Preta trabalhando no lotação.

42 Preta e Barão conversam no interior do lotação.

43 Preta e Emilia caminhada Brasilândia

44 Preta lê carta de Barbarah - na casa de Barbarah.

45 Barbarah escreve carta - na cela (flashbak).

46 Preta lê carta de Barbarah - na casa de Barbarah.

47 Preta e Emilia conversam deitadas na cama - na casa de Barbarah.

48 Preta compõe / amanhece - na laje.

49 Preta procura Mayah - casa de Mayah.

50 Preta e Mayah fazem as pazes.

51 Lena e Maionezi brigam - casa de Maionezi.

52 Meninas visitam Barbarah na prisão - no presídio.

53 Meninas compõem coletivamente - no presídio.

54 Show presídio (show grande).

55 Show final (show grande).

56 Créditos finais. 